\title{
Environmental Assessment for the Atmospheric Radiation Measurement (ARM) Program: Southern Great Plains Cloud and Radiation Testbed (CART) Site
}

Environmental Assessment and Intortination Sciences Division Argonna Nationa! Laboratory

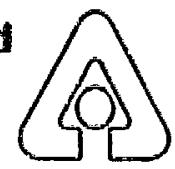

Operated by The University of Chicago. Uñdet Conlract W-3t-tog-Eng-38, for the 


\section{Argonne National Laboratory}

Argonne National Laboratory, with facilities in the states, of llinois and Idaho. is ewned by the Uniled States govemment, and operated by the University of Chicago under the provisions of a contract with the Bepartment of Energy.

This technical memo is a product of Argonne's Environmtantal Assessmene and Information sciencess (EA|S) Divigion. Fon information on the divisian's scententific and enginesering activities, centact:

Oirector, Environmenta! Assossment and Information Sciences Division

Argonite National Laboraton

Argonne, lllinoig 610439-4015

Tielephone: (708): 252-3759

Presented in this technical memo are praliminary resultz of ongong work of work that is more limited in acope and ciopth than that de scribed in fomal regorth haguedl by the EAIS Diviator.

\section{Disclaimer}

This report was prepared as an account of work sponsorgd by an agency of the United States Govomment. Noither the United States Govemment nor any agency thereof, nof any of their smployoeg, makes any warranty, express or implied, or assumes any legal liability or rosponsibility lor the accuracy, completenesi, or ugofulness of any information, apparatus. product, or proceng dialelosed, or pepresents that its uge would not intringe prtvatoly owned dights. Folerence haroin to any specille commercial produck, process, or service by tracte name; trademark, manufacturar, op otherwise, does not no:osastily constifute of imply its ondorsomont, recommenditton, or lavoring by tha Unitod States Govommant of cany agency thereot. The views and opinions of authers oxprossed herein do not necossarily state or reiloct those of the United States Govemment or any agency therøot. 
Environmental Assessment for the Atmospheric Radiation Measurement (ARM) Program: Southern Great Plains Cloud and Radiation Testbed (CART) Site

by A.d. Folicagtro, J.M. Plingston, D.M. Maloney, F. Wasmet, and E.D. Pentecost

Environmental Assessmont and Inlormation Sciences Division, Argonne National Laboratory. 9700 South Cass Avanue, Argonne. Illinois 60439

Work sponsored by Unized States Department of Energy. Office of Energy Research, Otfico of Hoalth and Environmental Fesearch. Almospheric and Climate Research Division 


\section{Executive Summary}

The Atmospheric Radiation Measurement (ARM) Program is aimed at supplying improved predictive eapability of climate change particularly the prediction of clout-climate feedback. The objective will be achieved by measuring the atmospheric radiation and physical and meteorologieal quantities that control solar radiation in the earth's atmosphere and using this information to test global climate and related models.

The proposed action is to construer and operute it Cleut and Radiation Testbed (CART) ressarch site in the southern Great Ptains as part of the Depurtment of Energy's Amospheric Radiation Meswrement Program whose objective is to develop an improved predictive capability of global elimate change. The purpese of this CART research site in southem Kansas ind nuthen Oklahoma would be to collect meteorological and other scientific information to better chardeterize the processes sontrolling radiation transfer on a global seale. thereby expanding DOE's knowledge of the stupected enhanced greenhouse effect and any assuctated global warming.

The CART site proposed for the southem Great Plains covers ant tho $325 \mathrm{~km} \times 275 \mathrm{~km}$

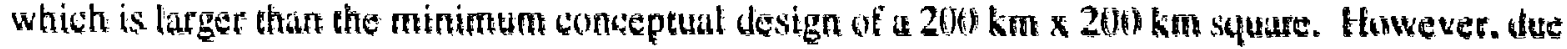
to the disbursed nature of the instrumentation located on the CART site. it would be necessary to lease only a small portion of this area in order to implement the proposed action. The propessed CART site would be comprised of a single central tacility ( 160 acres). six auxiliary fucilities (5)t00 acres each), approximately 25 extended tacilities $(50)-100$ acres each). and up to six boundary tacilities (50-160 acres each). Thus, of the nearly 22 mittion acres within the proposed CART site area. only 3,860 acres would need to be leased ter these widely distorsed datin collection fiacilities. Of the total leased acreage. about $2 l$ acres would be sectered by fenceline and the surface within the tenced areas would not be disturbed except for the placement of instruments and assuciated tacitities. The total surtise area disturbed for concrete pats to support such items as trailers. storage facilities, and housing facilities is estrmated to be less than 12 atres. It is proposed to operate the CART site around-the-clock for up to 10 years with up to 36 technical statf persons. At the close of the 10 year operating period. all facilities and equipment would be removed and the land returted tor its previous use.

Air quality impacts of placement and operation wauld be very miner since omily a small amount of clearing and a small amount of leveling would be needed. State of Oklahmma tegulations on fugitive dust mitigution te.g. watering to reduce emissiuns) would be followed during the construction.

$N$ ise impacts to nearby residents were evaluated for the ponentially noisy 50/ and 915. MHz proffter/Radio Acoustic Sounding Systems (RASSs). The nuise from these instruments represent a low (for 50 MHz RASS) or high (for $915 \mathrm{MHz}$ RASS) frecpuency tone that uccurs $5-6$ minutes of every 30 or 60 minutes. The results were that:

1. The 5()-MHz proffler/RASS was found to be acceptable at the central facility for the propesed action and each of the alternatives. The baffled $50 \mathrm{MHz}$ 
profiler/RASS was found to be acceptable at the boundary sites for each of the proposed actions and for some (but not all) of the proposed altemitives.

2. The 9:5-MHz RASS system was found to be acceptable at all proposed sites and altematives including the central tacility and the six boundary facilities.

Research aireraft would occasionally carry out fow-level passes at 500 ft above ground level. The proposed aircraft would cause momentary speech interference for people under the flight path, at minor impact.

Water resource impacts would be very minof, with khe requirement for two boundury fidsilities (McClain and Okmulgee County) that construction and operational activities would be carried out in specitied subportions of the sites to avoif kloodplain and wetlands areas.

Impacts to vegetation and witulite would be low and temporary. Non theatened or endangered species would be at risk. Land use impucts would be very low because of the limited areal requirements of the project. The projest impacts to visual resures surtounding each site wotkl be low. The only structure in the entire project that would be visible trom a vantage parne of

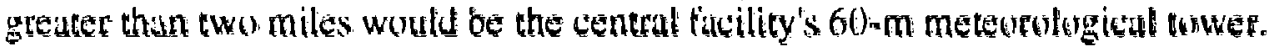

The impacts to cultural resources would be minor. The stute historicul preservation ofititars (SHPO) of Oklahoma and Kansas indicated that nome of the proposed or alternative sites for facilities contains structures or sites listed in the National Register of Historic Places. The lower elevation of the Marion County (Kansas) site may contain archeologital sites, but these areas would be strictly avoided.

Suctoeconomics impacts would be minimal. Some minor economic benefits would recur in the vicinity of each proposed site, but these would consist of briet employment 130 days maximum) for only a few workers and the focal purchase of support materials.

Because the ARM Project activities are located in isolated rural areas where there is very little activity other than farming, the cumulative impacis would be negligible. Furthermure. this project represents new effort and has no cumulative impacts with any previous DOE work or with any other facterd projects.

The no action alternative would be the loss of a U.S. site. which would be fetrimefrial to the scientific study of global warming. The loss of the U.S. site would severely limit the ability of the project to vastly improve modets and to make appropriate policy decisions on global climate change. 


\section{Contents}

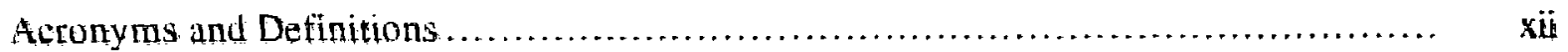

$\$$ Description of Proposed Action and Alternatives ............................. $\quad$ =

1.1 Purpose and Need $\ldots \ldots \ldots \ldots \ldots \ldots \ldots \ldots \ldots \ldots \ldots \ldots \ldots \ldots \ldots \ldots \ldots \ldots \ldots \ldots \ldots \ldots, \quad 1-1$

1.2 Experimental Design .................................................... $\quad 1-2$

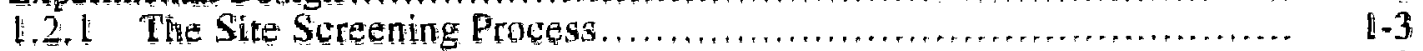

$1.2,2$ First Level Sereening ................................................ $\quad 1-3$

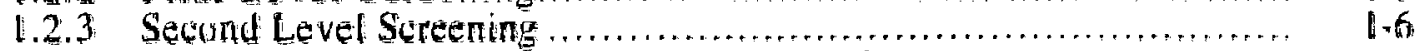

1.3 Getalts ol che Proposed Action in Oklahuma and Kansas.................. $\mid$ - $\$$

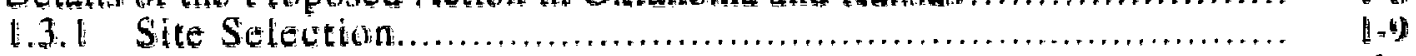

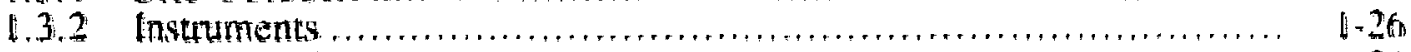

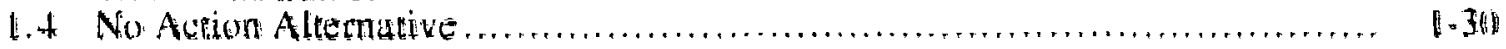

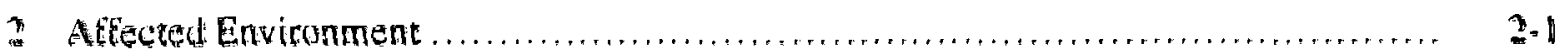

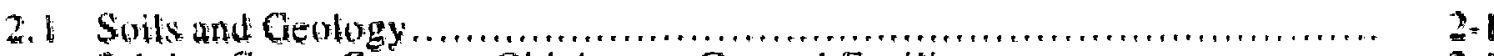

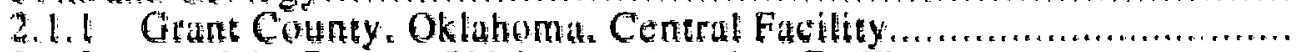

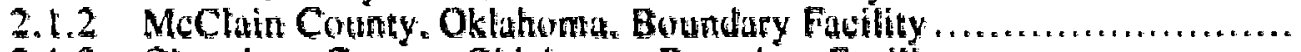

2.1.3 Okmulgee County, Oklahoma. Boundary Facility $\ldots \ldots \ldots \ldots \ldots \ldots \ldots \ldots$

2.1.4 Woodward County Oktahoma. Eoundary Facility......................

2.1.5 Kiowa County, Kansas, Boundary Fosility ............................

2.1.6 Marion County, Kansas Boundary Facility............................

2.1.7 Montgomery County, Kansas, Boundary Fucility .....................

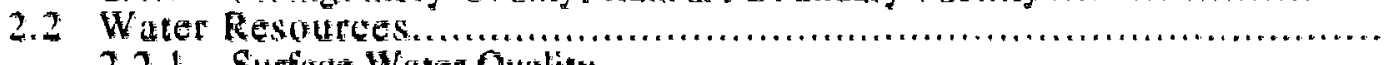

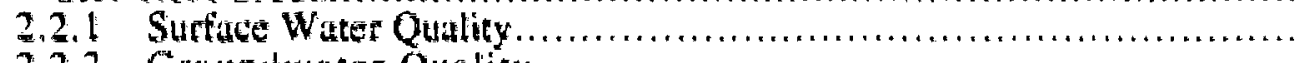

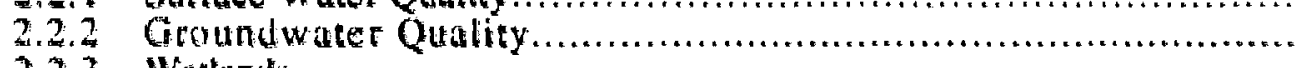

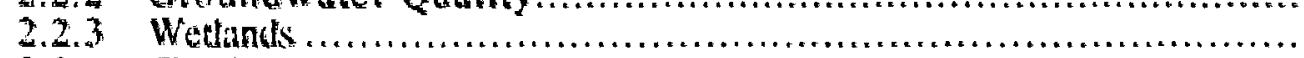

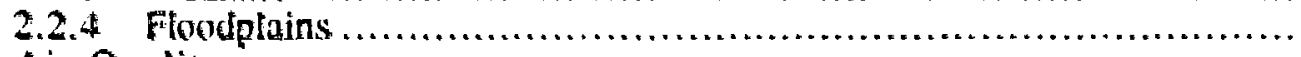

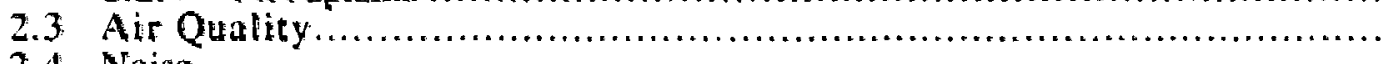

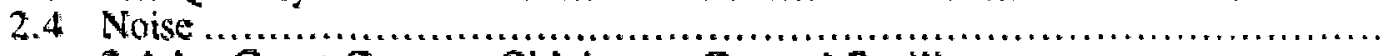

2.4.1 Grant County. Oklahoma Central Fatilizy....................................

2.4.2 McClatin County, Oklahoma, Boundary Facility ..........................

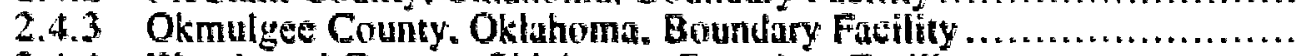

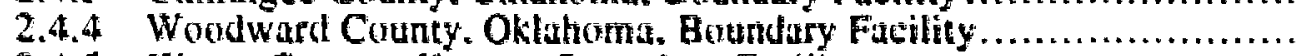

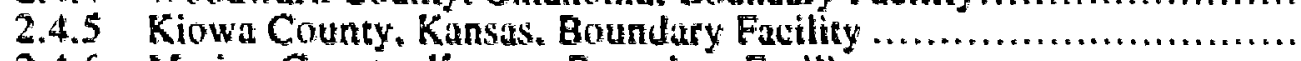

2.4.6 Marion County. Kansas. Boundary Facility ................................

2.4.7 Montgomery County. Kansas, Bovndary Futility ......................

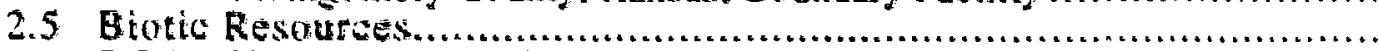

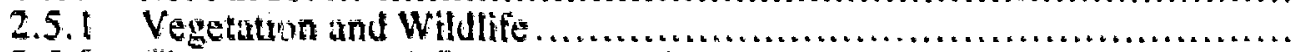

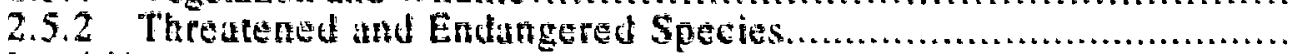

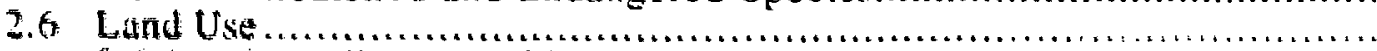

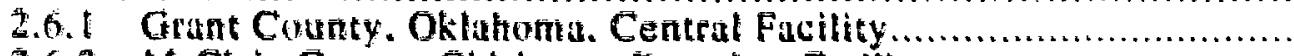

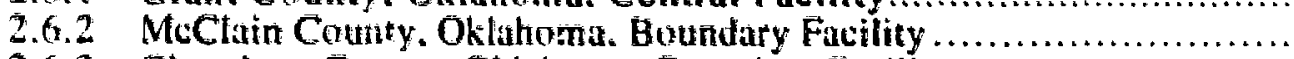

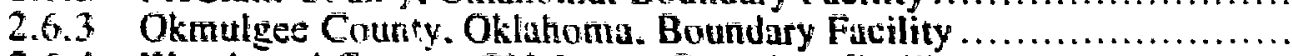

2.6.4 Wadward Couniy. Oklahoma. Boundary Facility.......................

2.6.5 Kiowa County. Karnsas. Boundary Facility

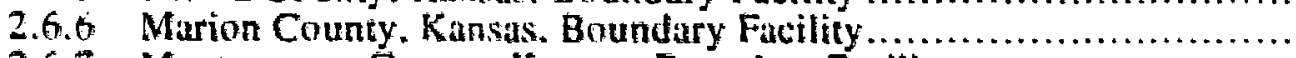

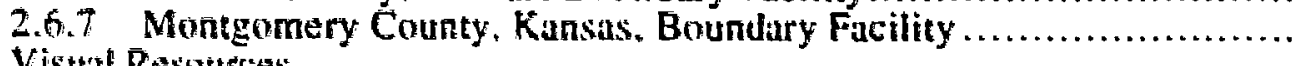

2.7 Vistul Resuurces:

2.7.1 Geant County. Oklahoma. Central Facility. 


\section{Contents (Cont'd)}

2.7.2 McClain County, Oklahoma, Boundary Facility .................... 2-25

2.7.3 Okmulge County, Oklahoma, Boundury Facility ...................... 2-26

2.7.4 Woodward Counzy, Oklahoma, Boundary Facility .................... 2-26

2.7.5. Kiowa County, Kansas, Boundary Facility ......................... 2-26

2.7.6 Marion County, Kansas, Boundary Faeiliky ........................ 2-27

2.7.7 Montgomefy County, Kansas, Boundary Facility .................. $2-27$

2.8 Cultural Resoutces ....................................................... 2

2.8.1 Grant County, Oklahoma, Central Facility......................... 2-28

2.8.2 Moclain County, Oklahoma, Boundary Facility ..................... 2-28

2.8.3. Okmulgee Cuunty. Oklahsma. Busudary Facility .................. 2-28

2.8.+ Woodward County. Oklathma, Bbundary Factity................... 2-28

$2,8.5$ Kiowa County, Kansas, Boundury Fatility ........................... 2.28

2.8.6 Marion County, Kansas, Butndary Futitity........................ 2.29)

2.8.7 Montgomery County, Kansus, Buundary Facility .................... 2.29)

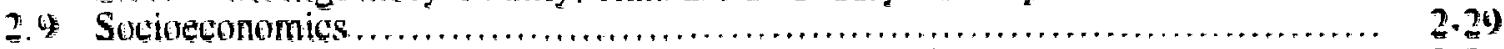

2.9.1 Grant Counky, Ok Lahoma, Central Facility .............................. 2-30

2.9.2 McClain County, Oklahoma, Boundafy Facility ...................... 2.30

2.9.3 Okmulgee County, Oktahoma, Butadary Fatitity .................... 2.31

2.9.4 Woodward County, Oklahoma. Boundery Facility ..................... 2.31

2.9.5 Kiowa County, Kansas. Boundary fasilty .......................... 2-31

2.9.6 Marion County, Kansas. Boundary Eacility........................... 2-32

2.9.7 Montgomery County, Kunsas, Boundary Facility ..................... 2-32

3 Environmental tmpacts of Propesed Action und Alternatives...................... 3-1

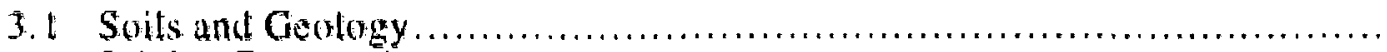

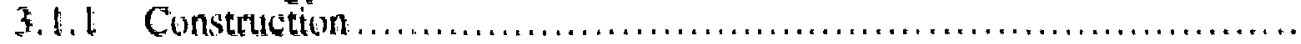

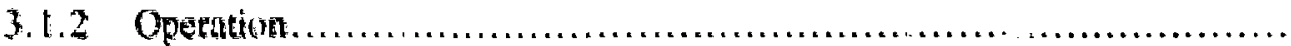

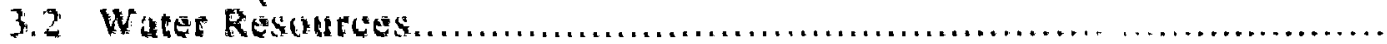

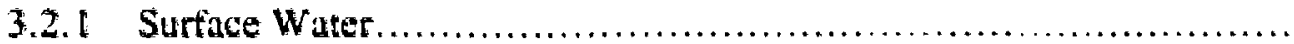

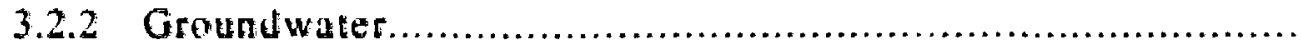

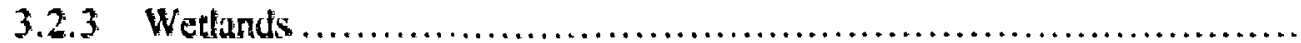

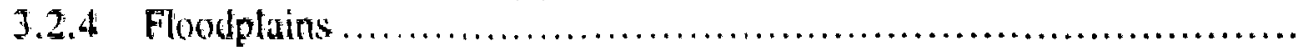

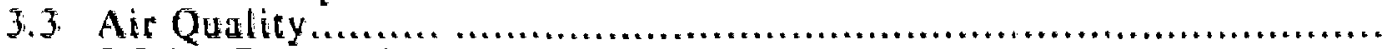

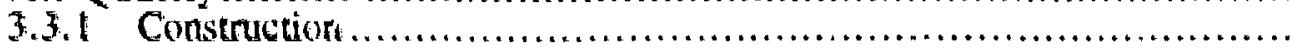

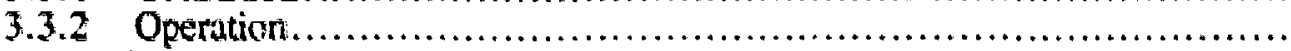

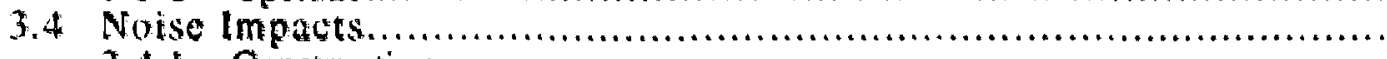

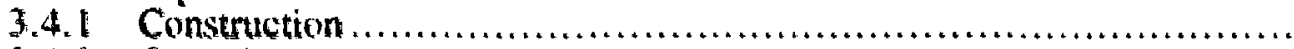

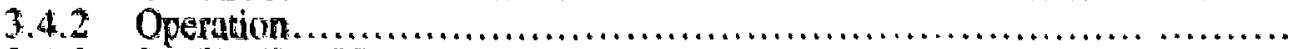

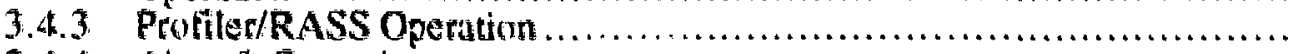

$3.4,4$ Aircraft Qperation ...................................................

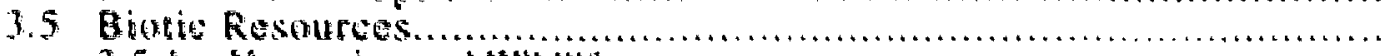

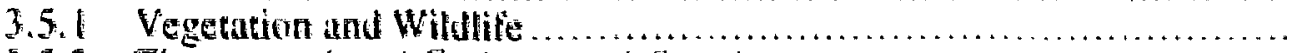

\$.5.2 Threatened and Endangered Species.....................................

3.6. Land Use

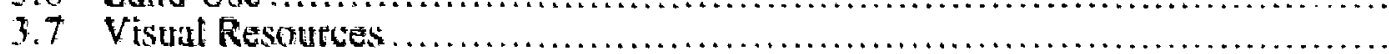

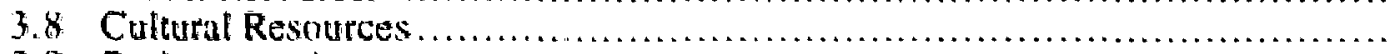

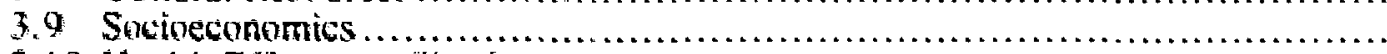

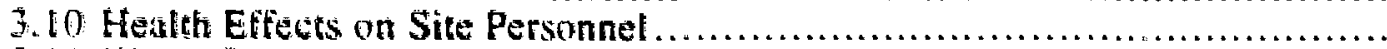

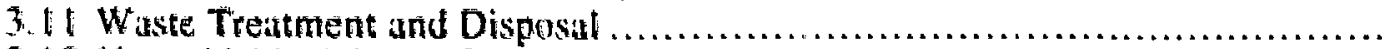

3.12 Unavoridable Adverse Impacts 


\section{Contents (Cont'd)}

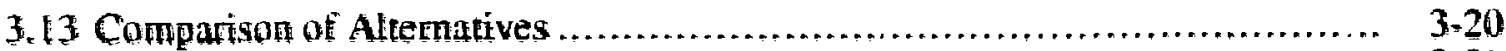

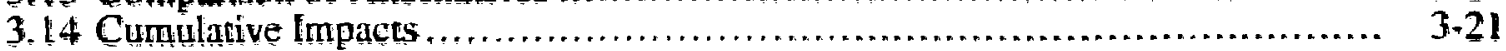

4 Summary and Conctusions........................................................ $4-1$

5 References......................................................................... 5

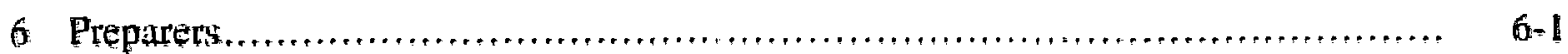

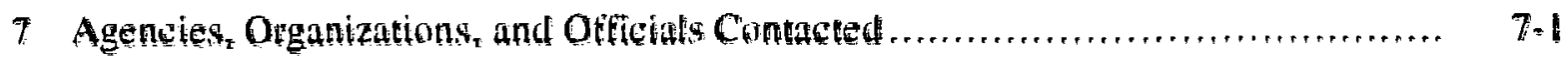

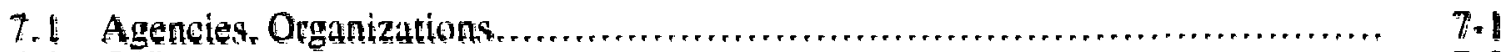

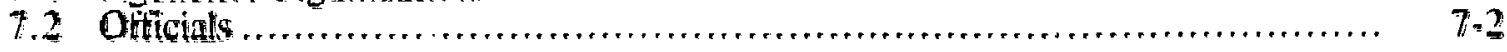

APPENDIX A: Landsat Scenes Used for Eind Use Classification ..................... A-I

APPENDIX B: Area of Surface Disturbance and Instrumbent Placertent fort Central. Boundary. Auxiliary, and Extendẹt Sires ......................... B.1

APPENDIX C: Descriptions of ARM-related Equipment and Instruments .............. C-1

APPENDEX D: Letters from Consulting Agencies .................................... D.1

APPENDIX E: Evaluation of Noise Impacts of the \$0-MHz and 915-Mktz Proftler/RASSs...

APPENDIX F: Federat Candidate Species Potentially Oecurting in Counties Containing ARM Project Central and Boundary Facilities.............. F-1

APPENDIX G: Existing Land Use Maps of Vicinity around Boundary Facilities

APPENDIX H: Photographs of Areas in Proximity to Grant and McClain County Facilities.

APPENDIX 1: National Register of Historic Places Listings for Oklahama and Kansas Counties Containing Central and Boundary Facilities

\section{Figures}

1. Telative Locations of CART instrumentation Intuding the Central Facility and the Boundary. Extended. and Auxiliary Fatilities within the CART Area

1.2 General Configuration of the ARM Measurement Grid and Representative Instrumentation for the Central Fatility... 


\section{Figures (Cont'd)}

1.3 The Levation of the 325-km $\times 275-k$ m CART Experimental Area

within the Southern Great Plains (Oklahoma and Kansas) ..................... 1-10

1.4 Distribution of CART tnstrumentation among the Central, Boundary.

Extended, and Auxitiary Facilities.

1.5. Relative Orientation of Instrumentation within the 160-Acre CART

Centrat Fistity

1.6. Relative Orientation of Instrumentatun within a CART Boundary Facility .

1.7 Relative Orientation of Instrumentation within a CART Auxiliary Facility ....... $\quad$ 1- lat

1.8 Relative Orientation of Instrumentation within a CART Extended Futility ....... $\quad$ 1. 15

1.9) Siting of Central Facility in Grant County - Proposed Site and Alternatives $!$ and 2

1.40 Siting of Goundary Facitity in MeClain County -. Proposed Site and

Alternatives 1.2 . and 3

1.11 Siting of Boundary Facility in Okmulgee County .. Proposed Site and

Alternatives 1,2. and 3

1.12 Siting of Boundary Fucility in Wobdward County $\cdots$ Proposed Site and Atrecnatives 1 and 2

1. 13. Sithag of Boundary Eactity in Kiona County .. Proposed Site and Alternatives 1,2 , ind 3 .

1.14 Siting of Boundary Facility in Marton County .. Propused Site and Alternatives 1.2. and 3

1.15 Siting of Boundary Facility in Montgomery County .. Propowed Site and Altertatives 1 and 2

2.1 Existing Land Use in the fmmediate Vicinity of the Proposed Action and tos Atternatives (Central Fastity. Grant Continty. Oklahoma)

3.1 Decay of Strtnd Pressure Lever in Distance for the Profiler/RASSs

A.t The Path and Row of the 14 Landsat Scenes.

A.2 Procressed Land Satellite Data: Scene No. 1. Path 29. Row 33;

September 25.1988.

A.3 Processed Land Satellite Data: Scene No. 2. Path 28. Row 33:

August 4. 1989..... 


\section{Figures (Cont'd)}

A.t Processed Land Satellite Data; Scene No. 3, Path 27, Row 33;

August 28, 1988 .

A.5 Processed Land Satellite Data; Scene No. 4, Path 29, Row 34;

September 9. 1988 .

A.6. Processed Land Satellite Duta: Scene No. 5. Path 28. Row 34:

August 18, 1988.

A.7 Protessed Land Satellite Data: Scene Nor 6. Puth 27, Row 34;

June 27.1988.

A.8 Processed Land Satellite Data: Scene No. 7. Path 29. Row 35;

September 8. 1988.

A.9 Processed Land Satellite Dum; Scene No. 8. Path 28, Row 35;

September 29, 1988.

A. (1) Processed Land Satellite Data: Scene No. 9. Path 27. Rthu 35:

August 26. 1988 .

A 11 Prosessed Land Satellite Datd: Scene No. 16. Path 26. Ronw 35:

September 20.1988.

A. 12 Processed Land Sateltice Data: Scene No. 11. Path 2\%. Row 36:

September 9. 1988.

A.13. Processed Land Satellite Data: Scene No. 12. Path 28. Row 36:

July 1\%. $198 \%$

A. 14 Processed Land Satellite Data: Scena No. 13. Path 27. Row 36:

August 5. 1989

A.15 Processed Land Satellite Data: Stene No. 14. Path 26. Ronw 36:

June 19.1989.

A. 16 Proposed Location of the Central Facility and its Two Alternatives

E. 1 Decay of Sound Pressure Level with Distance for the Pratiler/RASSs.

E.2 Histogran of Sound Pressure Level Measurements

E.3 Estimated Commutity Response vs. Composite Norise Rating - Modified CNR Model.

E.4 Relationship Between Annoyance and Detectability of Intruding

Noises .. Fitdell Mudel.

E.5 Cumulative Probability vs. Fidell's Category of Aanoyance 


\section{Tables}

1.1 Legal Descriptions of the Propcsed and Alernative Sites tor the

Central Facility and Six Buundary Facilities.

2. I Distance of Closest Residence to Each of the Proposed and

Alternative Sires.

2.2 Federally Listed Threatened and Endangeret Spectes Oceurring or

Potentialty Oecurring in the Countes Conkaning Central

or Boundary Facility Sikes.

2.3. Agriculture in Countes Comtaning Peoposed and Altentative

Facility Sites in 1984

2.* Population and Growth Rates in Countes Combining Propused and

Alemative Facility Sites, $1980=1990$.

2.5 Labor Forte and Unemployment in Countes Containg Perposed and

Altemative Facility Sites August 1491

3. Sound Power Level of the Various Protiler/RASSs

3.2 Minimum Distance bewwen Protuler/ RASSs and Nearest Residences.

as Predicted by the Moditied CNR Methot.

3.3 Acceptable (A) and Unacceptable (U) Sites for the Profiter/RASSs

According to the Criterta of the Mudified CNR Method tor

Acceptability of Noise Impacts

3.* Highly Amnoyed Parcentage of a Populated Community

3.5 Lل Lovel tor the Various Aircente at Difterent Otfset Distances.

3.6. Voice Effort Required tor Direct Spect Communteatior as a Funetim of Maximum Intrusive Noise Levei (tmax) and Distance

between lndividuals.

3.7 $L_{\max }$ Level for the Various Aircate at Diferent Ofiset Distances.

B. l Surtace Distubandes at a Typieal Central Facility

B.2 Surtace Disturbances a a Typisal Butudary Facility

8. 5urface Distutbances at a Typieal Auxiliary Facility

B.4 Suttice Distutbances at a Typical Extended Facility

B.5 Total Surface Disturbances by All Facility Types and Tutal Surface

Disturbances to the CART Study Area.

8.6 Instrument Status for Southern Great Plains 


\section{Tables (Con*td)}

E.l Sound Power Level of the Varimus Protiter/RASSs........................... E-6,

E.2 Medsured Ambient Noise tevels Uself in Modeling at Protiler/RASS

Noise Impact.

E-8

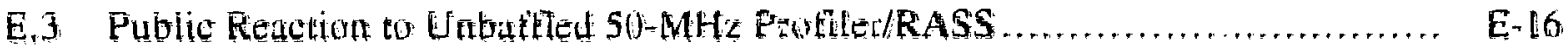

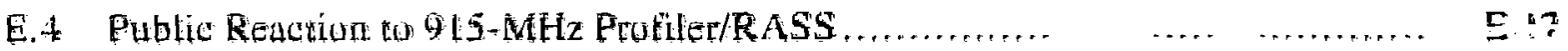

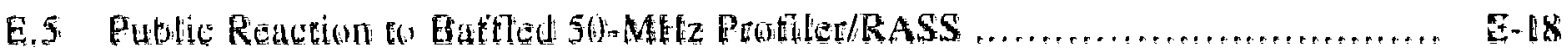

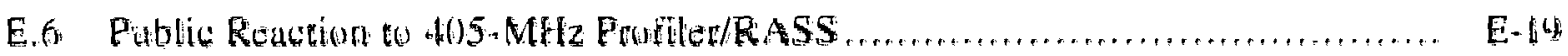

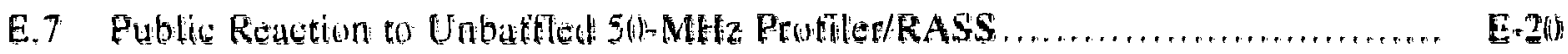

E. P Public Reation to 9:5-MHz Profiler/RASS ..................................... E-2!

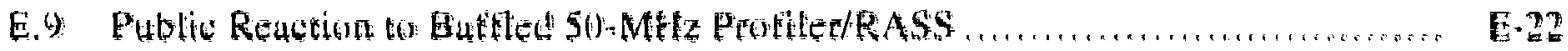

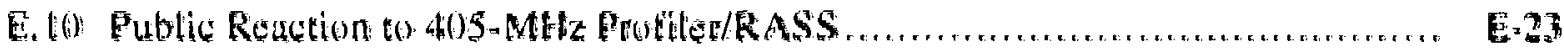

E. It Rublit Reaction to Unbafled 5()-MHz Proffler/RASS ................................. E.24

E. 12 Public Reaction to 9:15-MHz Protiler/RASS ...................................... E. E

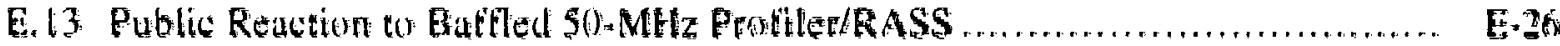

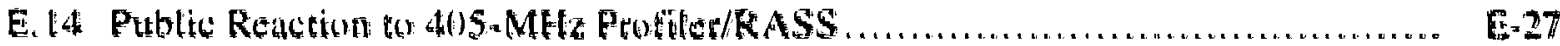

E. IS Acceptable (A) and Unaceptable (U) Sites for the ProtiletefASSs using the Criteria of the Moditied CNR Method tor Acceptability of Noise Impacts. 


\section{Acronyms and Definitions}

\begin{tabular}{|c|c|}
\hline $\mathrm{ARM}$ & - Amospheric Radiation Measurement \\
\hline CART & - Cloud and Radiation Testbed \\
\hline CART site & - a conceptual block of atmosphere and its uncerlying atmosphere. \\
\hline CNR & - Composite Noise Rating model \\
\hline CRP & - Conservation Reserve Pogram \\
\hline DOE & - Department of Energy \\
\hline EA & - Environmental Assessment \\
\hline ERDAS & - satellite analysis soltware packige \\
\hline FAA & - Federal Aviation Auministration \\
\hline FEMA & - Federil Emergency Management Agency \\
\hline tacilities & - grot pings of instruments \\
\hline FWS & - Fish und Wildlite Service \\
\hline GCM & - General Circulation Model \\
\hline GIS & - Gẹgraphic Inturmarion System \\
\hline gpat & = gatlons per minute \\
\hline IAP & - Individtal Annoyance Prediction modal \\
\hline lecale & - a subcontinent-sized region that is meteorologically representative of likal climate. \\
\hline MESONET & - Oklahoma mesoscale meteorological network \\
\hline $\mathrm{MSS}$ & - sitellite Multispectral Scanner images \\
\hline $\mathrm{MOA}$ & - military operations area \\
\hline NEPA & - National Environmentul Policy Act \\
\hline NOAA & - National Oecanic and Atmespheric Auministration \\
\hline PNA & - Probabilistic Noise Audibility model \\
\hline RASS & - Radio Acoustic Sounding System \\
\hline SHPO & - staie historical preservation oflicer \\
\hline USGS & - U.S. Geological Survey \\
\hline UTM & - Universal Transverse Mercator Courdinate System \\
\hline
\end{tabular}




\section{Descripition of Proposed Action and Alternatives}

\subsection{Hopose and Need}

The recent heightened public concern abott potential global warming due to an enhanced greenhouse effect has ptompted the U.S. Department of Energy (DOE) to accelerate its research to improve predictions of climate change. The emphasis is on the timing and magnitude of climate change as well as on the regional characteristics of this change. The Armospheric Radiation Measurement (ARM) Program was developed to supply an improved predictive capability. garticularly prediction of cloud-climate feedback. Improved resolution and aceuracy about radiative and cloud physical processes in the earth's atmosphere will be incorporated into general cifculation models (GCMs) and related models used to predict climate cthange. The objective is th vastly improve modets to study global climare change. This objective will be achieved by measuring the atmospheric cadiation and physical and meteorologital quantities that control soish radiation in the earth's atmosphere and by using this intormation to test GCLws and related models. Because of the dominant influence of clouds on radiation, the ARM Program will emphasize developing improved descriptions of e'unds for modeling purposes.

A systematic examination of the number and tocation of independent locales required t: charaterize the processes controlling radiation transter in the atmosghere on a glubal scale to meet the ARM objectives has been completed (Schwartz et al.. 1991). The following ordered set of independent and climatologically distinct primary locales was recommended for long tema (up to ten years) oçupancy as ARM "Cloud and Radiation Testbed (CART)" sites:

1. United States ctuntinental

2. Tropical western Pacitic

3. North slupe of Alaska

4. Eastern North Pacific/Eastern North Atlantic

5. Gulf stream off eastern North America

The ARM Program is a research activity funded by the U.S. Deparment of Energy (DOE) in support of the National Energy Sirategy and is managed by DOE as an independent field measurement program. reviewed and approved by the Office of Science Technology Policy's Conmittee on Earth and Environmental Sciences as part of the coordinated national initiative, the U.S. Global Change Research Program. The overall ARM Program involves substantial computational research activity at universities. companies, federal agencies. and national taboratories: indeed, the bulk of the funding supports this research. while a relatively small portion will be invested in the anticipated five sites and associated temporary facilities. The overall budget is expected to be $\$ 460$ million nver ten years (i.e. an average of $\$ 46$ million per year): however. the actual funding for site factities and operations is expected to be approximately $\$ 5-10$ million per site over ten yeurs.

While the types of instruments used and the activities performed will be similar for each ARM CART site, the environmentsl impacs may vary significantly from one site to another (e.g.. continental U.S. is significantly different from the tropical western Pacific Ocean. and both are 
significantly different from the north slope of Alaska). Program implementation will proced incrementally. The planning tor operation of the tirst ARM CART site is well underway, with a planned operational date of April 30, 1992. Each of the remaining CART sites is planned to become operational subsequently, at a rate of approximately one site per 18 months.

Planning tor CART sites 2-5 is preliminary, and it is not yet known how the ARM concept will be applied to sites other than the first. Although the measurement concept would be the same tor each of the sites, the experimental design would be different due to the very different nature of each of the CART sites. In addition, the logistics would be different. For example, a site over land would have a different measufement strategy than a site ther water. There would be differences in instrument placement and operation. althwgh the instruments would be simikar at each CART site. It is quite possible that the resufts of medsurements at this tisst CART site may leut to changes in the measurement plan at future sites. Consequently, additional documents meeting the requirements of the National Environmental Policy Act (NEPA) would be prepared individually tor each of the CART sites as they are ready to enter the program. Because instrumentution at the other CART sites would be similar, and each of the sites ure expected to have similar requirements as those for the continental US. CAR ${ }^{T}$ ite, the current Enviremmental Assessment (EA) would serve as a model for the orther sites that follow later. This EA contains overall program-related inturmation pertaining to the entife ARM Program and all hive potential CART sites that will hetp to shorten future EAs.

This EA addresses potential environmental impacts associated with siting. construction. and operation of research tacilities only at the ARM continental U.S. site.

\subsection{Experimental Design}

The heart of the ARM Program is a meteorological observatory. The APM Program will provide experimental and computational support tor a detailed study of solar and terrestrial radiative transfer and for the generalization of the results to physical scaltes compatible with current and tuture generations of GCMs. The basic experimental design for ARM incoportes four groups of facilities within a CART site. The area of the CART site is a concepual bluck of atmosphere and its underlying surface. The size of the CART site is driven by the size of the smallest area (or grid) that a GCM model can mathematically represent (ajproximately $200 \mathrm{~km} x$ $200 \mathrm{~km}$ ). The rationale for having the four groups in the CART site is the following:

1. One central factily ( 160 acres) within the CART site would contain a complete set of all instrumentation that would be used to characterize the local radiation field and meteorologicul conditions and the concentrations of aernsols and trace gases.

2. Approximately 6 boundury fucilities teach $50-100$ acres would contoin sets of instruments similar to that of the central facility, but slightly reduced that would characterize the mesoscale atmospheric conditions that affect the CART site. 
3. Six auxiliary facilities (each $50-100$ acres) would contain a reduced subset of instruments that would be used to characterize clouds, radiation, and meteotological conditions over the central facility.

4. Approximately 2s extended facilities (each 50-100 acres) would contain a much reduced set of instruments that would be used to characterize surface meteorological and radiation conditions throughout the CART si:

Figure 1.1 illustrates the orientution of the various facilities within the CART site. Figure 1.2 presents a schematic diagram of the relative focations of the central facility and its supporting boundary, duxiliary. and extended tacilities, all within the CART study area.

\section{2.t The Sito Screaning Process}

The continental U.S. CART site selettion was driven primurily by scientifie requirements and synergism with other projects, and secondarily by operational. financial. and logistic considerations. However, the actual locations of facilities within the CART site are tlexible. After first addressing candidate CART sites in the continental U.S.s proposed and altemative futilities fostions were identified and potential environmental inpats were addessed for the CART site. These potential impacts are presented in this EA.

\subsubsection{First Lovet Scroening}

In 1991. Schwartz et at. identitied lucules globally by using a set of selection principles that are consistent with the objectives of the ARM project. This selection proress developed a priortized tist of tocales. This first level of streening identified a set of subcuntinent-sized regions, termed locales. within which the broad range of physicul provessies that govern the quantity. structure. and radiative transfer properties of climatically important cleuds is well represented. The main selection criteria used for identifying the ten CART sites are the collowing:

1. A broad sampling of the types. guantities. and attitudes of clouds: of energy transfer characteristios of the earth's surface; of vertical motion fields: snd of temperature and humidity distributions in the atmospheric column above the CART site.

2. Quasi-uniform surtuce of cloud conditions across a CART site to minimize uncontrollable variables to increase the chances of interpreting causal dependencies.

3. A minimum set of logistical constratnts in conducting measurements. For the selection of the litst CART site logistical concerns will have a high priority to factlitate establishment and confirmation of operating procedures and instrumentation. 


\section{CART FACILITY LOCATIONS}

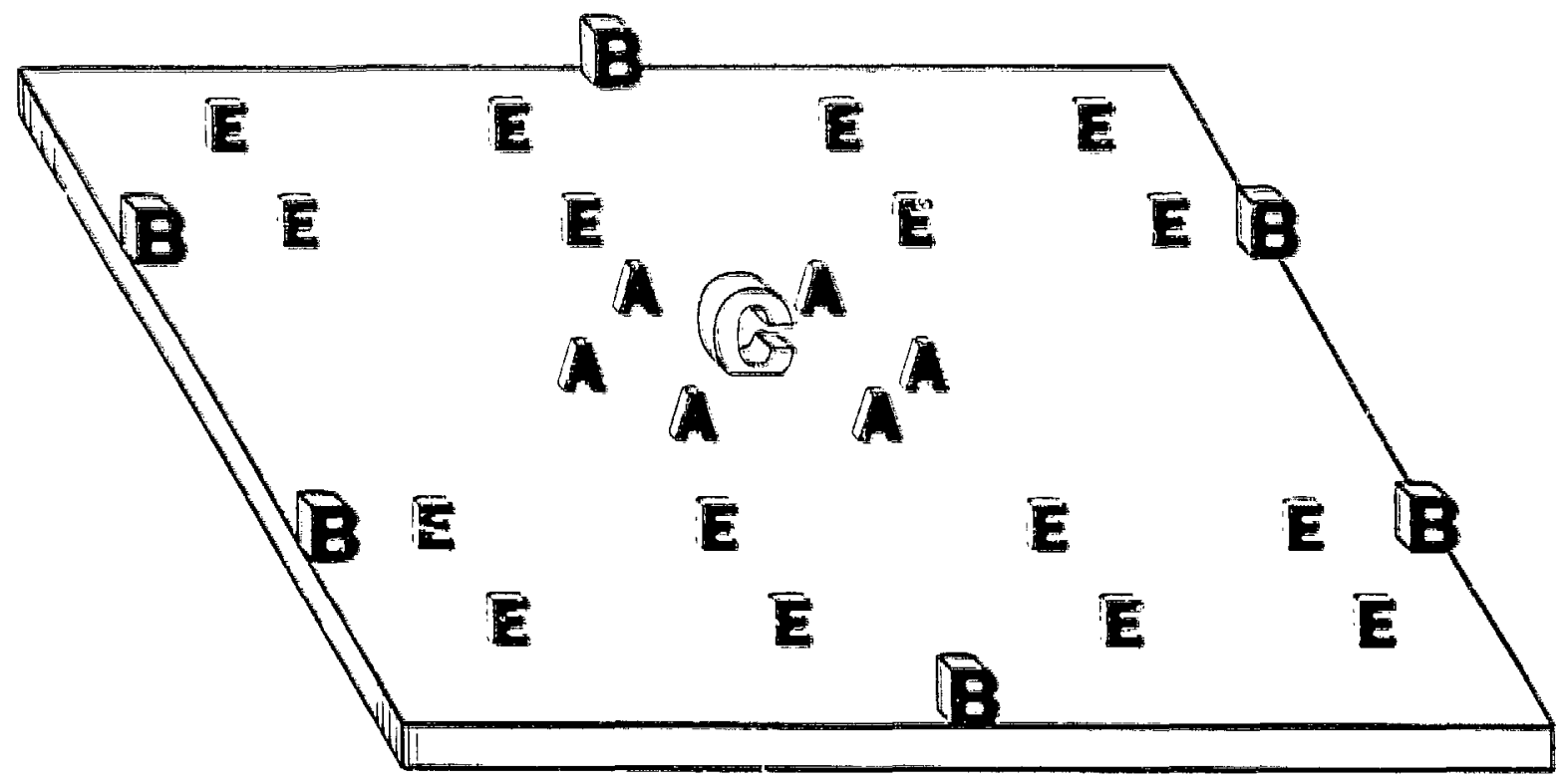

Q8 Central FacLLITY

B BOUNDARY FACILITIES

A AuXILIARY FacILITIES

E EXTENDED FA.CILITIEŚ

Figute 1.t Relative Locations of CART Instrumentation Including the Central Facility and the Boundary, Extended, and Auxiliary Facilities within the CART Area 


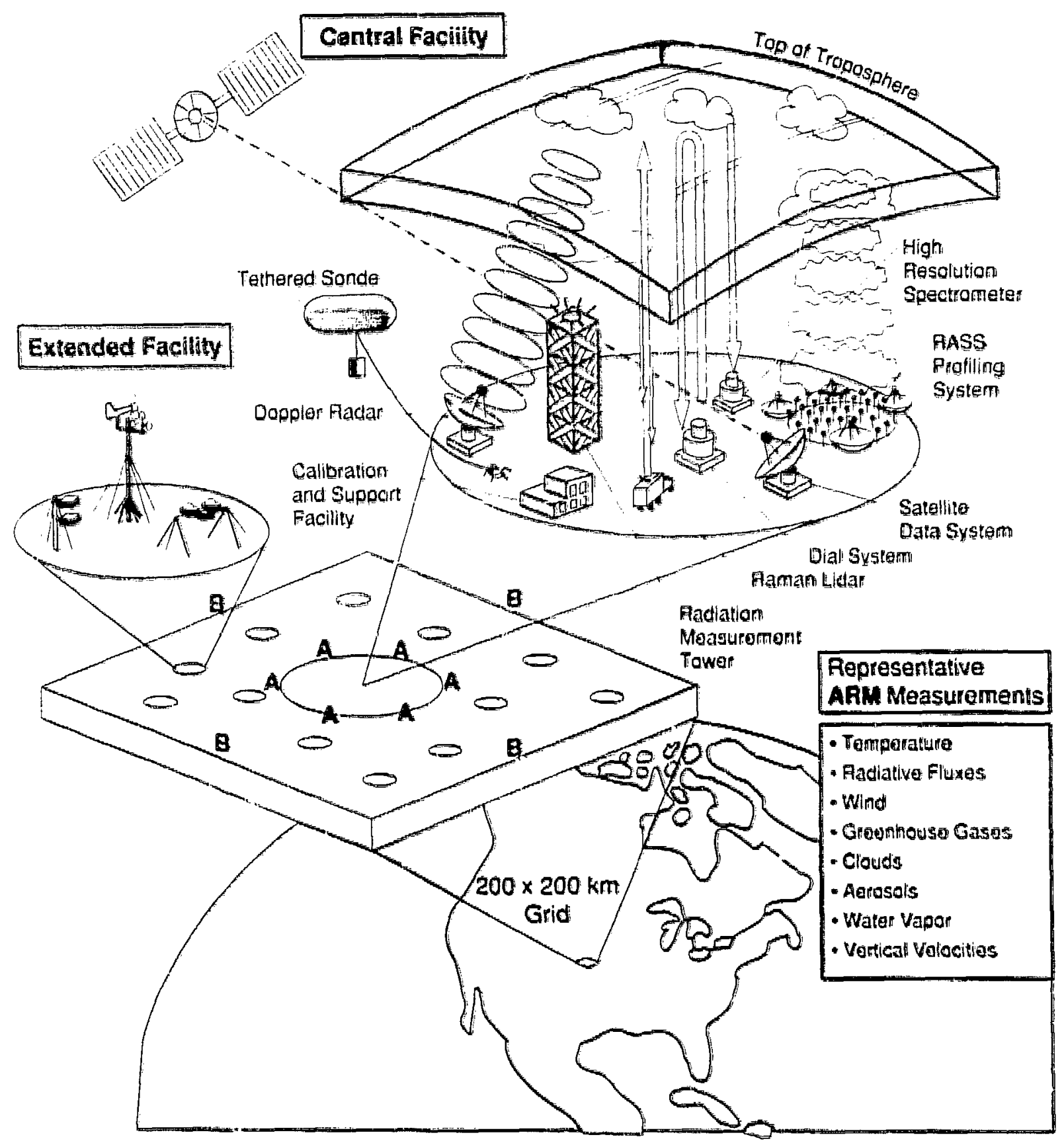

Figure 1.2 General Configuration of the ARM Measurement Gitd and Represenlative Instrumentation for the Centsa! Facility 
4. Potential synergism relationships with other data-gathering programs. Complementary amospheric research programs being conducted in the same general area mutually beneftc from the enhanced observational networks or supplemental instrumentation available by close cooperation.

The study of Schwartz et al. (1991) identified ten possible CART sites and prioritized them. Two locales representing similar cloud conditions in eastern ocean margins were merged. leaving nine candidate locales. In preparation is a series of nine companion documents, one bur each of the recommended tocales. These reports forus on the specific scientific, logistical, and synergistic issues that characterize the particular tocales.

The tirst priority was atontinental locale within the U.S., with three candidate regisms: the Midwest, the suatherti Great Plains, and the aurthern Great Plains. The primary reasuns for chousing the continental U.S. as the first choice of the nine lecales were as fullows:

1. The wide range of ctoud and radiation conditions supports a major portion ot the ARM scientikic ubjectives.

2. Operational prescedures and intertices with data users and interested parties can be developed and tested in the shontest possible time. at the lowest cost.

3. Instrument pertormance can be evaluated under a fairly wide range of environmental conditions in a setting where improvements cian be made most easily, quickly, and coss effectively.

4. New instrument systems in transition from research to operation can be introduced and evatuated betore they are deployed at more remote sites. This practice will avert costly redeployments.

\subsubsection{Sacond Loval Scraening}

All three locales within the continental U.S. offer excellent logistic attributes. gund geographic homogeneity. large intra-annual variability of slimate cloud type and surtace flux properties, a wide variety of cloud types. and large seasonal variability in temperature and specific humidity.

The proposed action for this EA begins with the evaluation of the three locales. The scientific debate over the "best" towide with regard to the above attributes did not produce a clear cariditule bur the ARM continental locale. The Midwest. southem Great Plains, and northem Great Phains loca es all have excellent logistic attributes: gond gengraphic homogeneity: large intra-annual vartability of climate. cloud type, and surface thux properties: a wide variety of cloud types: and large seasonal variability in temperature and specific humidity. However. the southern Great Plams locule provides the best opportunity for synergistic activity with several other major federal research programs. For example, the dense array of seven National Oceanic and Atmospheric Adninistration (NOAA) protilers (405 $\mathrm{MHz}$ microwave radars for continuous wind profile 
rneasurements) have already been installed and are operating in the southern Great Plains. The Oklahoma Climatological Survey has proposed a meteorological mesoscale nęwork (MESONET) consisting of 109 sites in Oklahoma that will be in place by December 1992 . This opportunity for synergistic activity does not mean that the existence of the ARM Progran in the southem Great Plains depends upon these other programs. The ARM Program aus budgeted such instrumentition where possible tor itcs own activities independent bot other yograns. Nevertheless, sharing instrumentation where possible would substantially save taxphyer dollars and would reduce potential environmental impacts by avoiding needless duplication of affort. In addition to the synergism of observations, there is a synergism in the climate, cluod, and air-surface exchange science that is potentially provided with local university and state scientitic interactions. No other U.S. locale provides the desired mix ut atmusphetite conditions und uffords proximity to as many

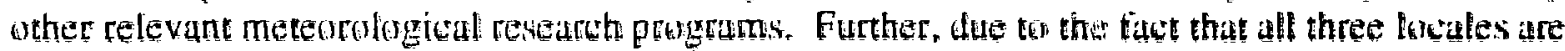
so expansive in area, there would be ample upportunity us pusition the widely disbursed datit

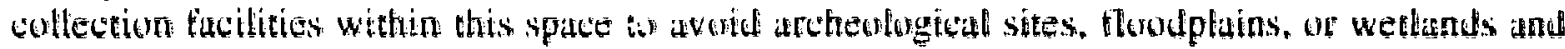
reduce any potential noise disturbance. Bevase of this and the similar elimatological profiles of the thee locales, none of the other locations demunstrated any envircumentul alvantages over the southem Great Plains site.

Since the sulthern Great Plains has been determined to be the best chatie in ferms of science and corferation with other related scientifie progrtms, the next part of the setwand level streening involved the actual siting of a proposed central theility and bundary tocilities where the instrumentation woutd be placed and operated. That determination was carried out in the following steps:

1. A set of 14 Landsat Multispectral Scanner (MSS) images (Appendix A) was wbtained to cover this $325-\mathrm{km} \times 275-\mathrm{km}$ atea. The MSS inage trum a typical tandsat scene has a swath of approximately $185 \mathrm{~km} \times 176 \mathrm{~km}$. The MSS data are widely used for vegetation inventories. The spatial ressilution af MSS Jata is $79 \mathrm{~m} \times 79 \mathrm{~m}$. Detectors record the electromagnetic radiation in four bands. Bands 1 and 2 are in the visible portion of the spectrom and are usetul for detecting co:ltural to atures such as rowds and detailing water. Bands 3 and 4 are in the near-intrared portion of the spectrom and can be used to discriminate land/water and vegetation.

2. Towns, roads, political boundaries. water budies, and rivers in the CART area were digitized trem 1:250,0001-stale U.S. Ganlogical Survey (USGS) maps. A preliminary defermination was made of candidate sections for locating the central tocility and six boundary sites. Then the towns, roads, political boundaries, sections, rivers, water bodies, ane NOAA profiler locations within ten miles of the propased sites were digitized from 1: InO.0mm-seale USGS mitigs.

3. The ERDAS software was used to classify the four-band spectral data from the MSS images to USGS Level I land use classes. The spectral characteristics of the data and the total county acreage from the National Resource: Inventory 1982 data for cropland. rangelind. pasture land. and forests were used to 
determine general land use classes, The classes determined were crop, majority crop, mixed crop and rangeland, rangeland and brush. grassy, water, dry creek beds, urban ${ }_{2}$ and wooded.

4. The ground truth of the classified data was partially established when Argonne National Laboratory staff visited selected areas and reported on current land use. This infortration indicated that good correlation exists between the classified land use datu and the current land use.

5. The land use information from the Landsat data was registered by using the Geogfaphic Information System (GlS) system to the Universal Transverse Mercator (UTM) coordinate system and combined with the digitized vectur information. dir space information was superimposed an the resulting map. Military operations areas, jot routes within a tour-mile band on eath side, and airfields were eliminated from consideration. Areas with ow air spare interference were identilied tor turther study.

6. Representatives of the Science Team studied the GIS maps w determine general areas trom which the spectitc proposed sites and atterative sites could be chosen tor the centrat tacitity and for the six boundary fuctities.

\subsection{Detalls of the Proposed Action in Oklahoma and Kansas}

The proposed action is to construct and operate a CART research site in the southem Great Platas as part of DOE's ARM Progerm whose objective is to develop an improved predictive capabitity of global slimate shange. The purpose of this CART research site in southern Kansass and Northern Oklahoma wouts be to collect metsorological and other scientifie infornation os better charaterize the processes controtling radiation transfer on a global scale. thereby expanding DOE's knowledge of the suspected enhanced greenhouse effect and any associated global warming.

The proposed action at the southern Great Plains locale includes the following steps:

i. The selection of an area for the tirst ARM CART reseurch site in the qwuthem Great Plains tocale to provide routine measurements of solar radiation and meteorological conditions.

2. The constrtiction of 1 central factility, 4-6 supporting boundary facilizies. 6 supporting auxiliary sitas and 25 supporting extended sites.

3. The operation of such a station for a period of up to ten years.

4. The execution of two- to three-week intensive experimental field campaigns primarily within but not limited to a $10-\mathrm{km}$ radius of the central facility. for special studies aimed at supplementing wark with the tixed instruments. 


\section{t.3.t Site Selection}

Ot the basis of the ARM Program documents entiled ldentificaion, Recomimiendation, and Iustification of Potential Locates for ARM Sites (Schwartz at al., 1991) und Locale Specific Report: Southern Great Plains (Barr and Sisterson, 1991), the CART site has been located within an area roughly detined by the latitude longitude cowrdinutes 38 deg $30 \mathrm{~min}$, 99 deg $30 \mathrm{~min}$ $38 \mathrm{deg} 30 \mathrm{~min}, 95 \mathrm{deg} 15 \mathrm{~min} ; 4 \mathrm{deg} 15 \mathrm{mir}, 2 \mathrm{deg} 30 \mathrm{~min}$ and $34 \mathrm{deg} 15 \mathrm{~min} .95$ deg 15 min. Figure 1.3 Hlustrates this 325- is 35 -km urea covering the northem part of Oklahoma and the southem part of Kansas. This area encompasses not only seven of the NOAA high-density profilers but ans many of tho Oklahoma MESONET tites. Although this area is farger than the conceptual 200 -kin 200 -km GCM grid its size does at increase the requifed number of tacilities

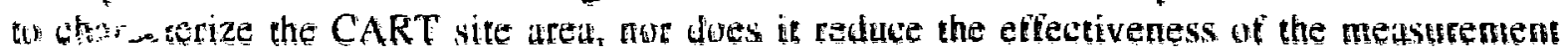
wtrategy. In tat tolocation with existing instruments is expected to increase the effectiveness ut

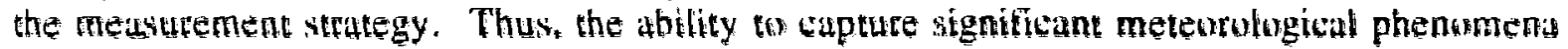
within a CM grid has not been compromised by assuming a larger conceptual CART area.

A CIS is being used to identify candidute areas tor each of the tactities within the CART site area. Scientifte considerations and the recognition of the benefits of the NOAA high-ulensity

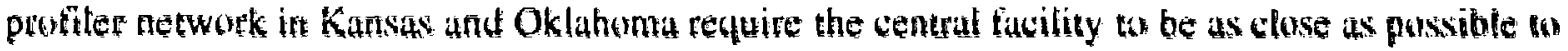

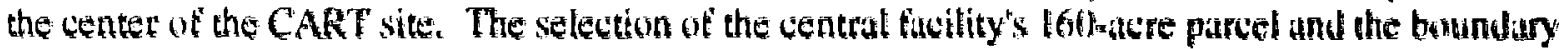
facitities" 50 - to 100 -acre parcels is therefore critical. "The locations of the remaining auxiliary and extended tacitities are not as critical.

The GIS atso included intormation about controlled air space oner the CART site. such as ratilary operating areas (MOAs), because there witt be airctith operutions involved with the ARM Program. Also included was anatyzed Landsat data that allowed land use categories to be identified the CART site area. Scientitic siting criteria included the avoidance of watlands. urban areas, torests, and significant changes in elevation. The Landsat analysis identifred crop and pasture lands as the dominant land use categories in this area for locations of facilities. These screening piecedures were nsed to identity candidate sites for the central and boundary facilities. Similas screening tor the remaining extended and auxiliary fucilities will take place at a later date. Scientific investigations using preliminary dat from the central tacility will be used to identily land uso categories that need to be characterized by measurements token at the auxiliary and extended facilities. The er ntrat facility at this firs CART site is planned to be uperational by Aprif 30.1092.

The locations of all facilities must fall within the conteptitai CAR't site bnundiries. Figure 1.4 provides a sketah of the instruments that are planned for use at the central. boundary. extended. and auxtiary tacitities. The planned layout of the central factity ( f fol acres) is given in Fig. 1.5: the boundary layer tactlity $(50.100)$ acres) is shown in Fig. 1.6: the auxiliary facility (5n. l00 actes) is given in Fig. 1.7 : and the extended facility (50) - 100) acres) is shown in Fig. 1.8.

The actual locations of facilities within those boundaries, however. are flexible. Serentific considerations of the program. which include land use. siting criteria for instruments, aireraft operations. and synergism with other programs. indicate one proposed site and at least two alternatives for each of the central and boundary facilities have been identified for formal NEPA 

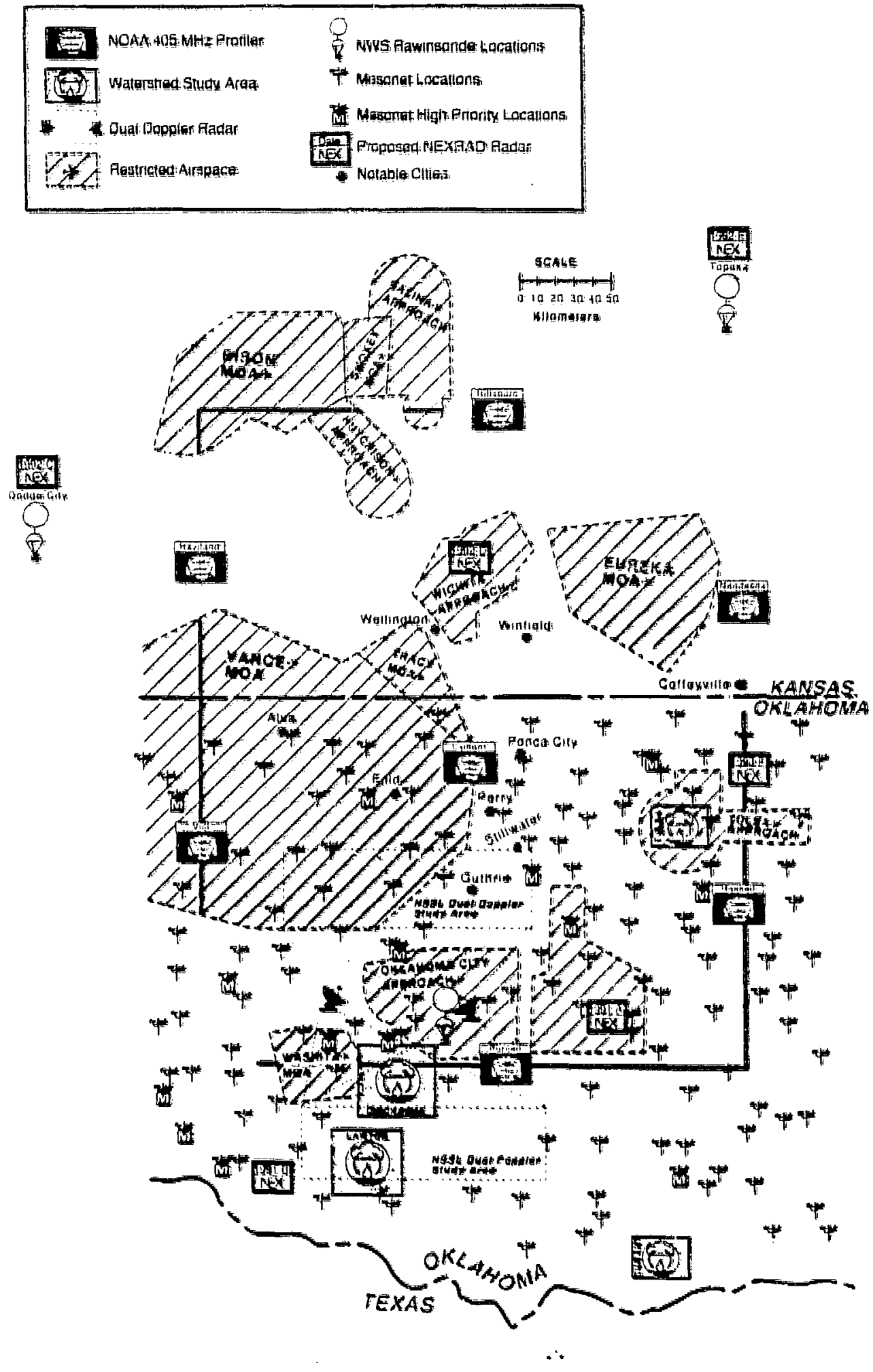

Figure 1.3 The Location of the 325-km $\times 275-\mathrm{km}$ CART Experimental Area within the Southern Great Plains (Oklahoma ano Kansas) 


$$
\begin{aligned}
& \text { C. B } \\
& \text { [1. : } \\
& \text { 11) }
\end{aligned}
$$

\section{$C_{A} A$}

A. So, Cartes:

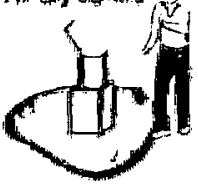

C, $B$

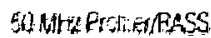

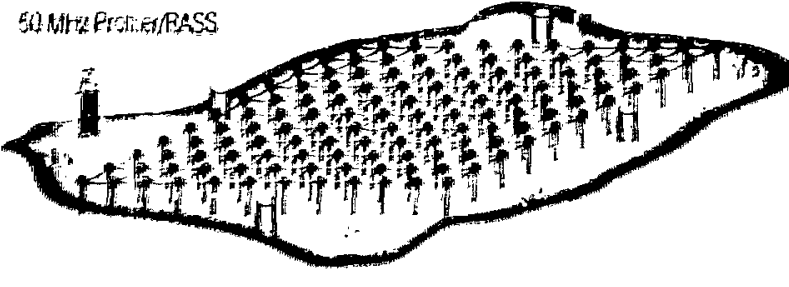

c

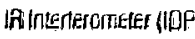

Ceitcricter (IDP)

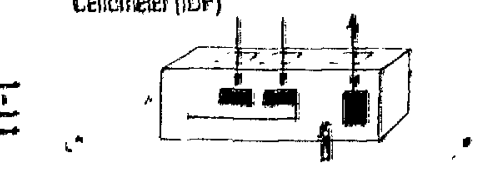

c

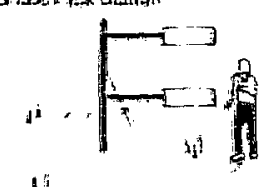

\section{$\mathbf{C}, \mathbf{B}, \mathbf{E}, \mathbf{A}$}

Broadband Aadiomiefrefg

$$
-\pi+4
$$

\section{c}

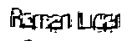

(Min)

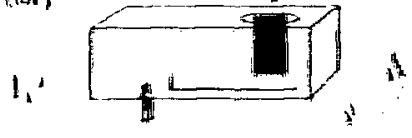

C, B, $E_{x, A}$

Srasefles Saturi

\section{A}

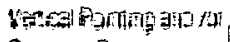
Segrighat

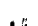

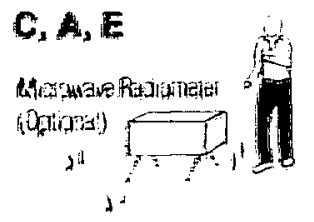

$\mathrm{C}, \mathrm{B}$

IA interteramelat (ILP) Balloun Borna

Sounging Wystem
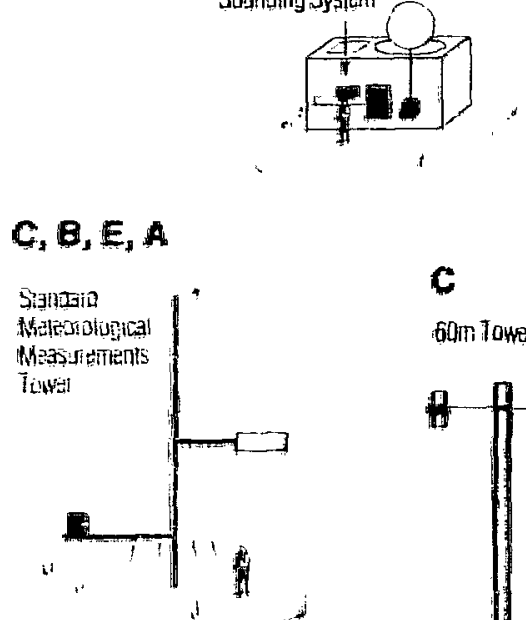

\section{c}

60in Towel

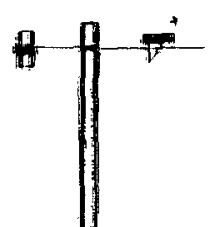

$c$

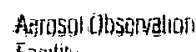

Fascility

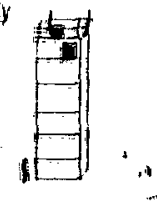

\section{CARI IMSTRUMENTS}

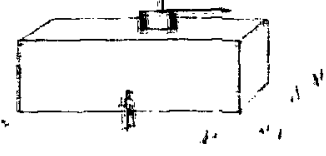

$\because 1$

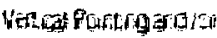

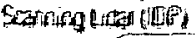

"

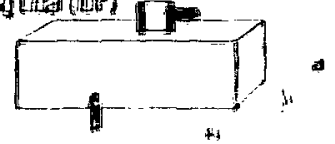

Figure 1.4 Distribution of CART Instumentation among the Central, Boundary. Extended, and Atuxilary Facilities 


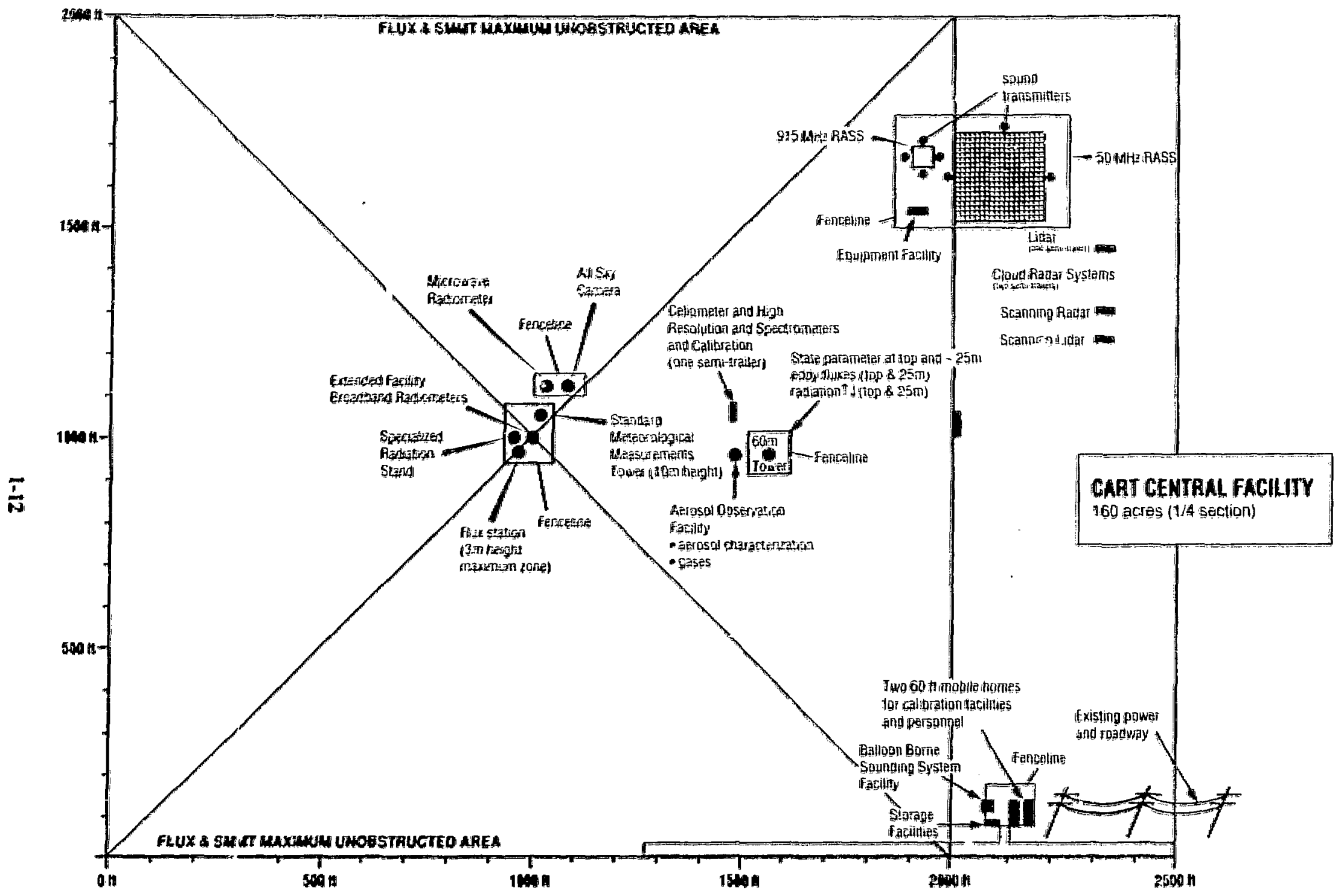

Figure 1.5 Relative Oriantation of Instrumentation within the 160-Acre CART Central Facility 


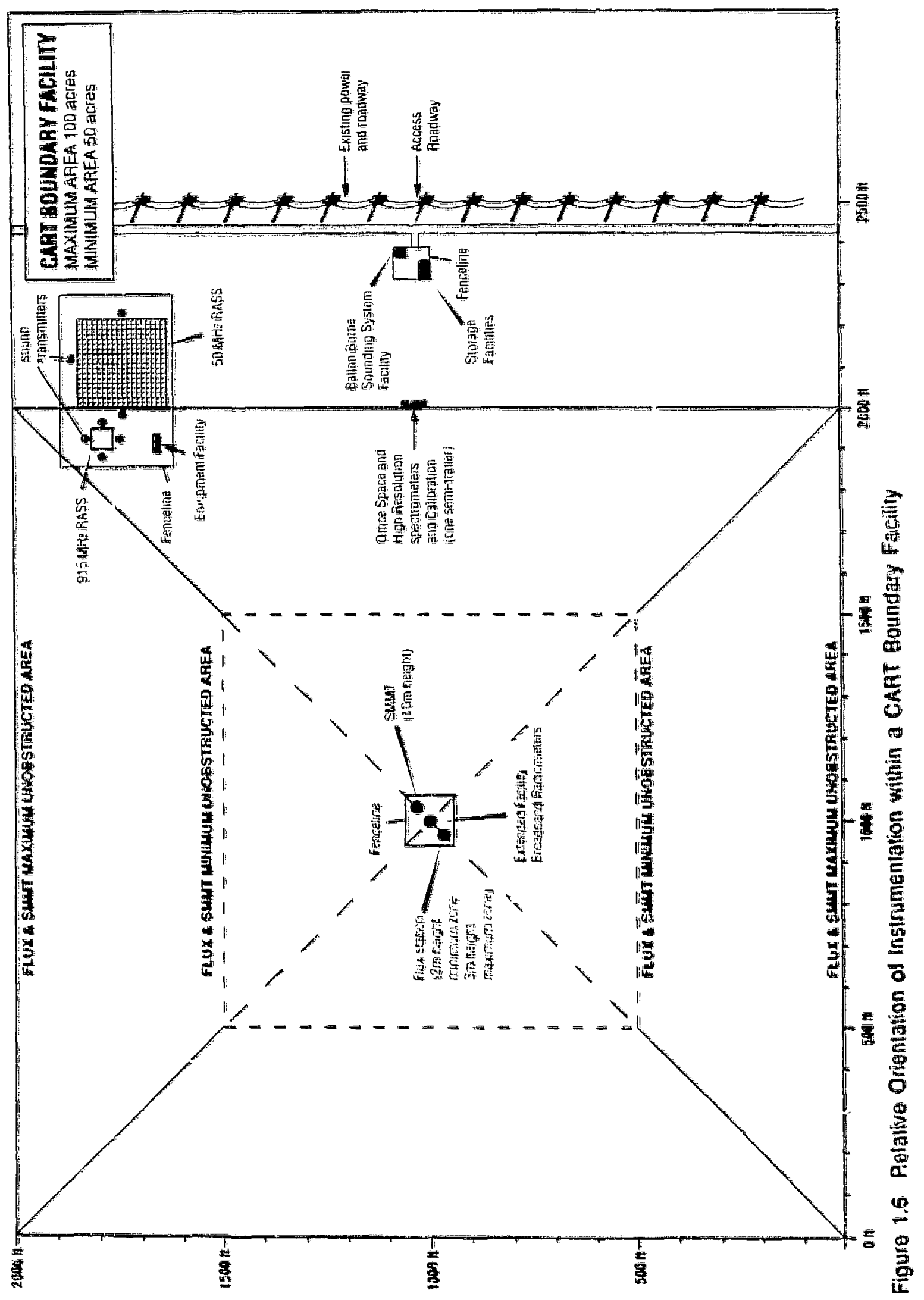




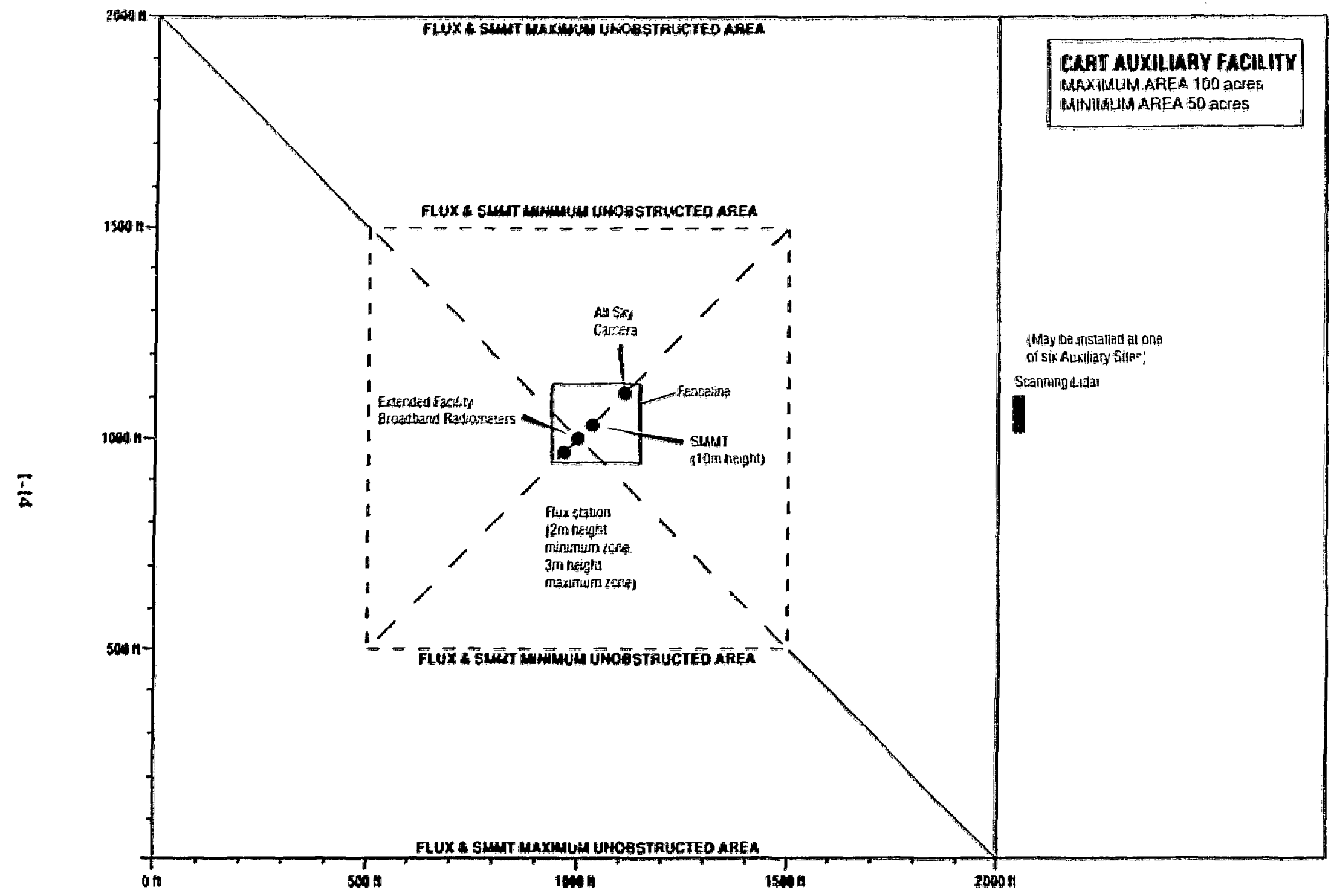

Figure 1.7 Relative Orientation of Instrumentation within a CART Auxiliary Facility 


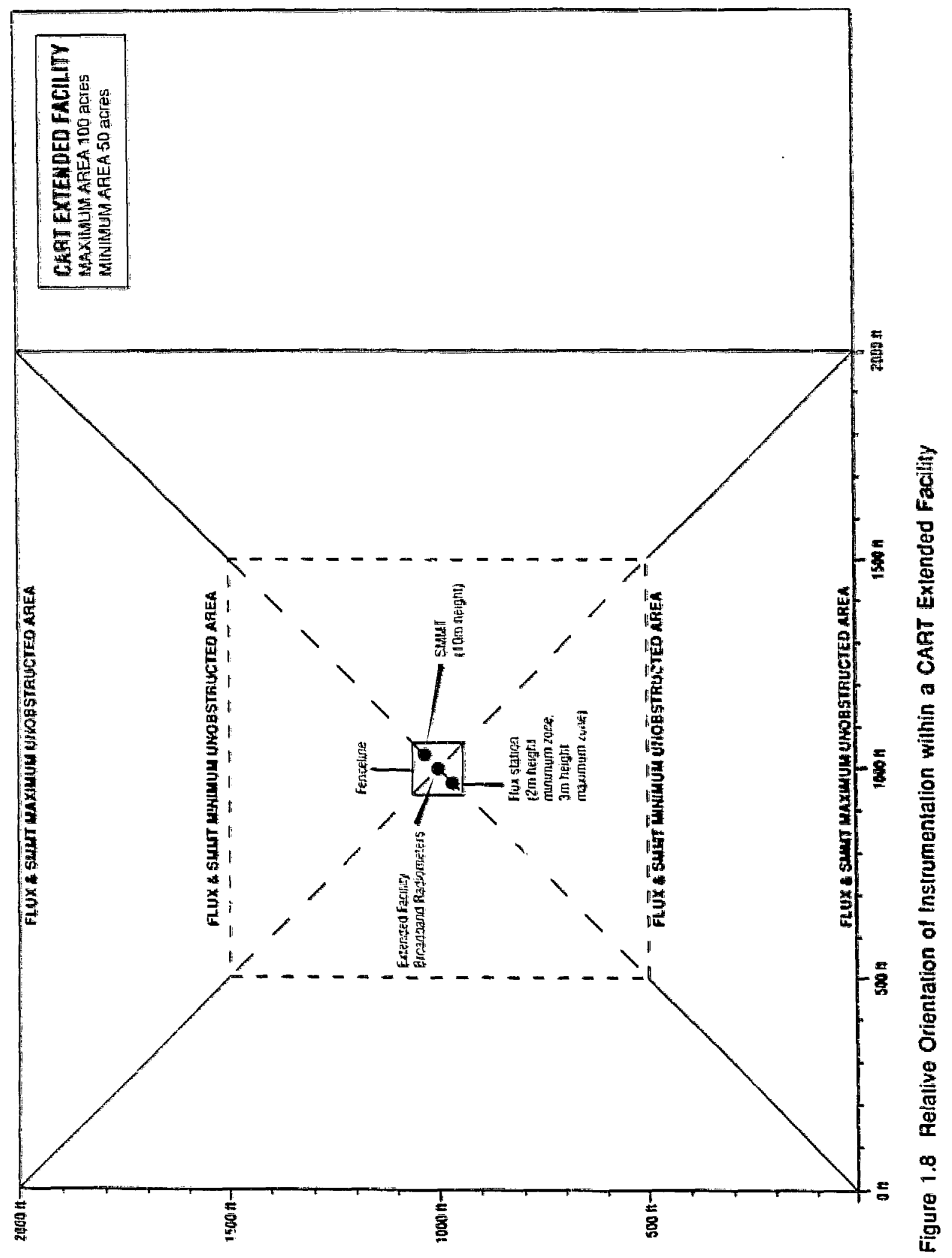


sereening in this EA. Figures $1.9-1.15$ provide sketches of the locations of the central and the six boundary facilities, inctuding one proposed site for each of these facilities and at least two alternatives tor eath of those tocations. The proposed central facility site is in Oklahoma. Three of the proposed taundary facilitirs are in Oklahoma, and three are in Kansas. Table 1.1 presents the legal descriptions of these sites. Each of the proposed sites and alternatives fit within a quarter section except for the proposed site for the two of the boundary facilities (McClain and Marion County). As indicuted in Figs. 1.10 and 1.14, the proposed site is divided into two parts: Part A contains all instruments except the 50-MHz RASS (Radio Acoustic Sounding Systern) which is located in Part $B$.

The proposed activities at the tour types at facilities would be encompassed within about 3.860 acres (central facility, 160 acres; atxiltary tucitities, $6 \times 109$ atres: extended tucilities, $25 \mathrm{x}$ 100 acres: and boundary tacilities, $6 \times 100$ atres). The actual disturbance to the surtace of the 3,860: acres would be minimal. Nearly all of the land at the various tacilities is required to provide the instruments with unobstructed wind thow in all directions. The actual surface area to be secured by lencing at all of the sites (Appendix B) totals about 21 acres, and the surtace within the fenced area would not be disturbed except for actual instrument plusement. The actual tord suriace area disturbed for concrete pads for trailers, storage facilities, housing tacitities, etc.. is estimated to be tess than 12 acres. The remaining portion of the area in each of these facilitics te.g.. the remaining $160-1.8=158.2$ acres of the central facility) would not be disturbed and continue with its same land use. All surfaces areas disturbed by activities walld be returned to agricultural use and/or pasture use as part of decormmissioning of the CART site, or they would be provided to the land owner, a university. or an interested state or federal agency for possible continued tigeration. At that time. however, another assessment of impats would be provided for appropriate approwal tor continued operation. If ne parties are interested, then all structures would be removed and all geaded of impacted surtaces would be reseded at the request of the property owner.

Attivities at the CART site would continue 24 hours per day. 365 days per year. for up o 10 years. Up to 36 technical staff persons would be required to operate the southem Great Plains CART site. The central facility would be the only location where the continuous on-site presente of 6 CART personnel maximum (and 6 alternates) would be required over a 24 hour period. Up (o 2 personnel (and 2 alternates) would be required to be at each of the boundary facilities for daily activities. The site would attract visiting scientists and olfikials for short periods during the lifetime of the site.

The main science or experimental activities include the collection and computer processing of data received by the in-place instrumentation. Once the facilities are in place the attivities and routine operations revolve aroum the collection of stolar and meteorological data. There will be no destructive tield sampling that will aftect the environment of the central, boundary, auxiliary. or extended facilities. Furthemore, operations: will not include the creution of any chemicals or haztardous waste.

The proposed action includes the following major activities:

1. The temporary acquisition of areas for placement of the central. auxiliary. exterided. and boundary tacilities. 
ARM PROGRAM SITE

GRANT COUNTY. OKLAHOMA

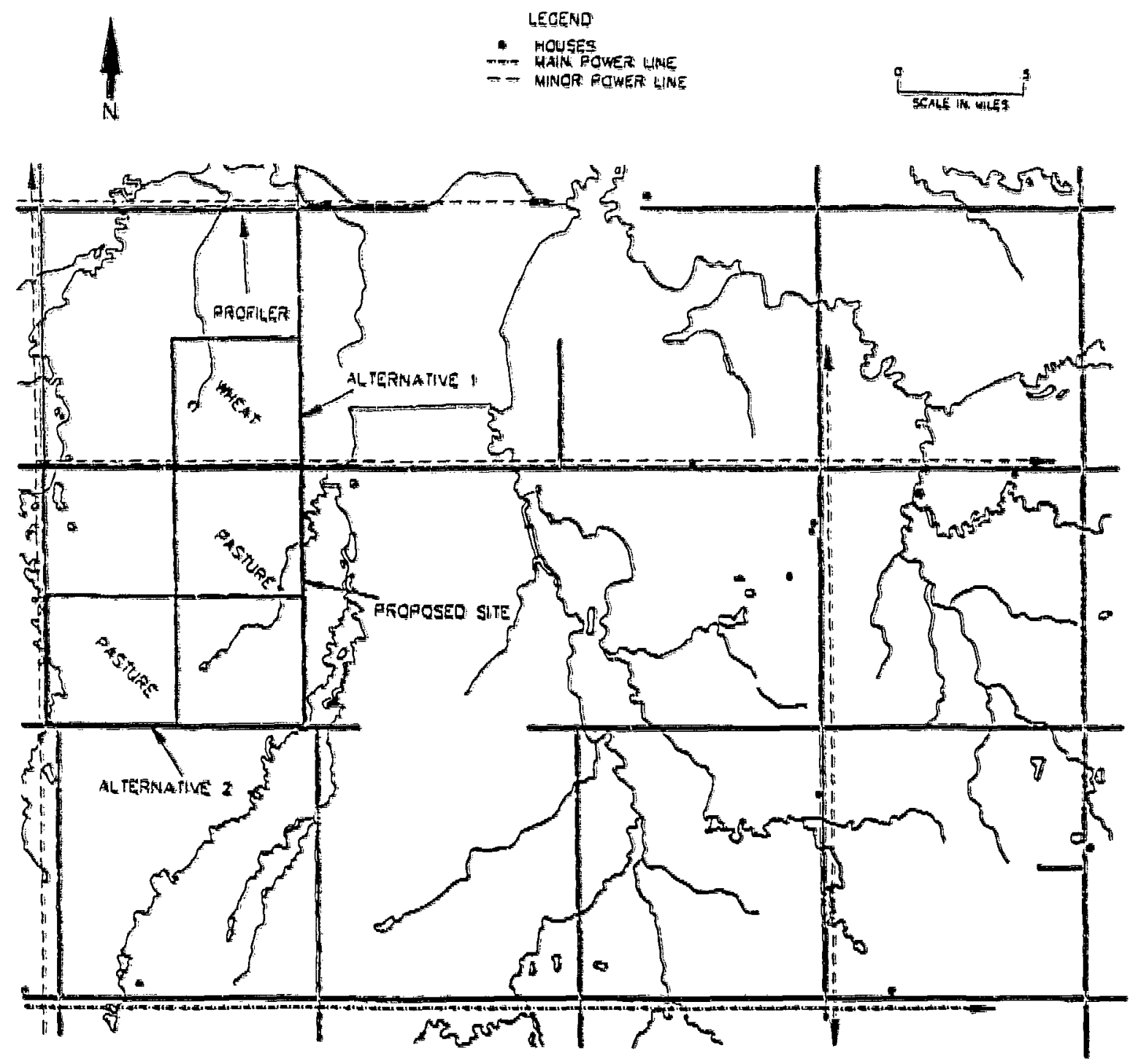

Figure 1.9 Siting ot Central Facility in Grant County .. Proposed Site and Alternatives 1 and 2 


\section{ARM PROGRAM SITE \\ MCCLAIN COUNTY, OKLAHOMA}

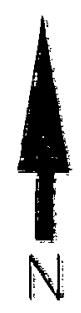

\section{LEGEND}
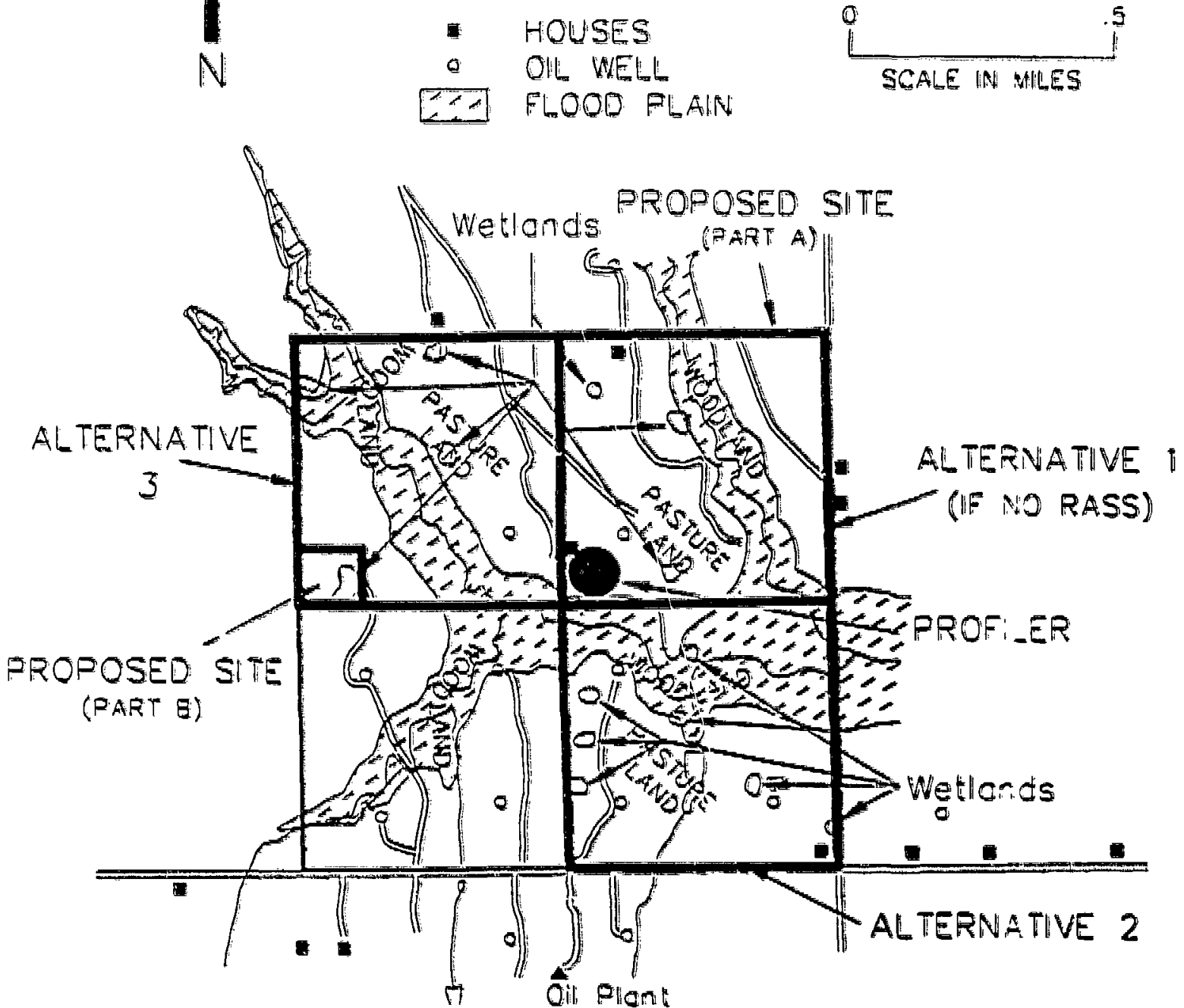

Figure 1.10 Siling of Boundary Facility in McClain County -. Proposed Sile and Alternatives 1. 2. and 3 


\section{ARM PROGRAM SITE \\ OKMULGEE COUNTY, OKLAHOMA}

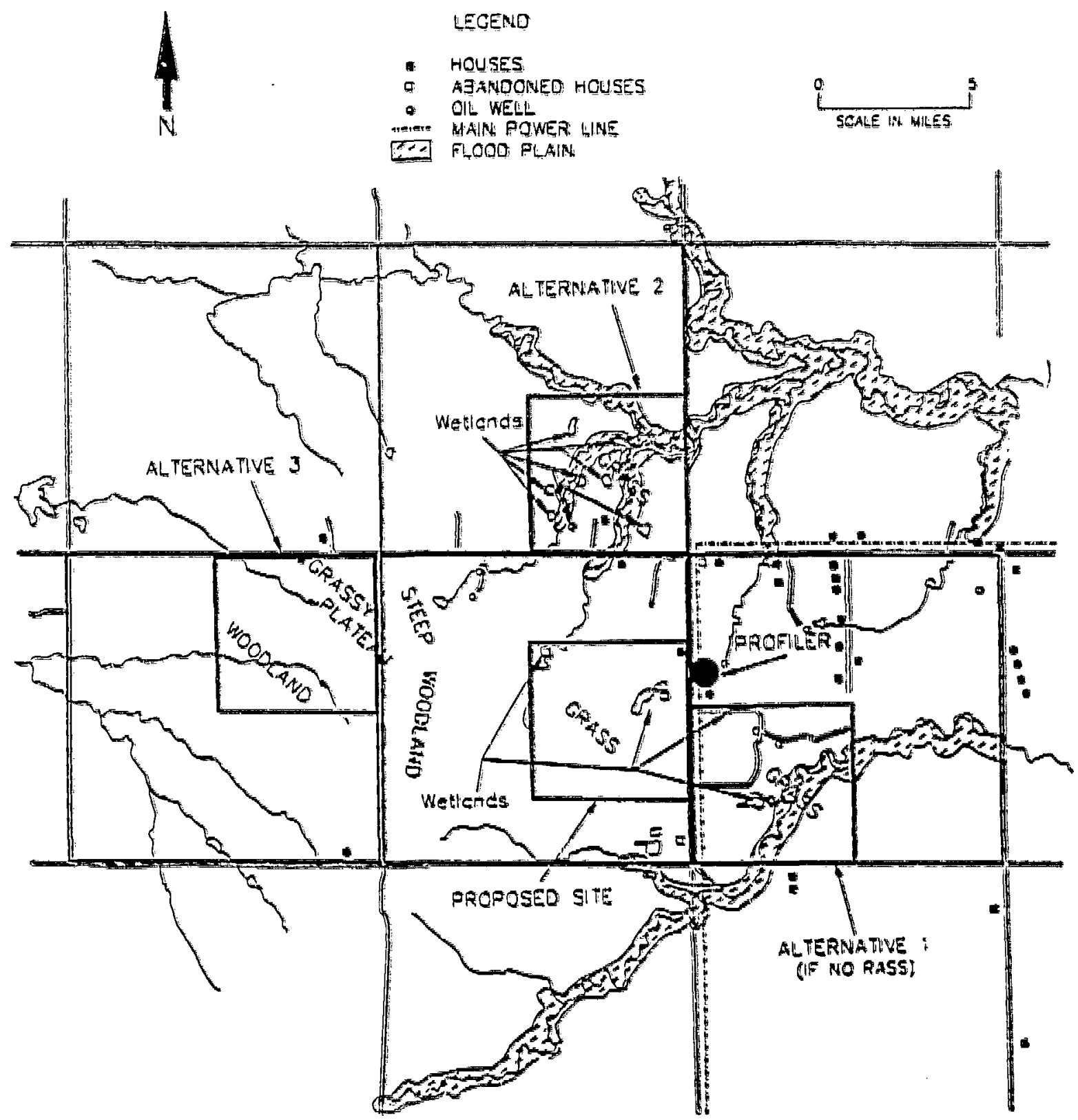

Figure t.tt Siling of Boundary Facility in Okmulgee Counly .. Proposed Sile and Alternalives 1,2 , and 3 


\section{ARM PROGRAM SITE \\ WOOQWARD COUNTY, OKLAHOMA}

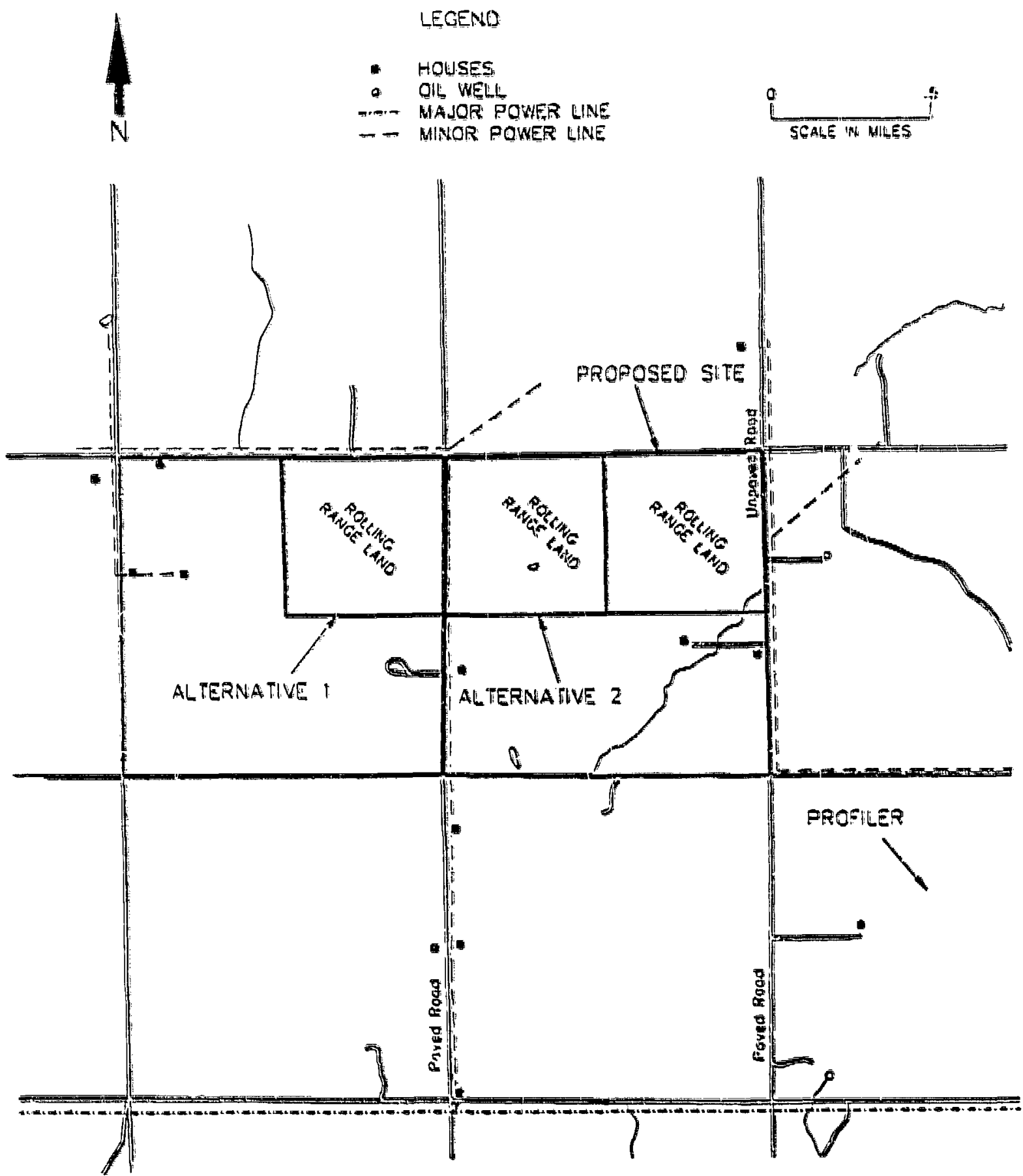

Figure 1.12 Siting of Bisundary Facility in Woodward County .. Proposed Site and Alternatives $t$ and 2 
ARM PROGRAM SITE

KIOWA COUNTY, KANSAS

f
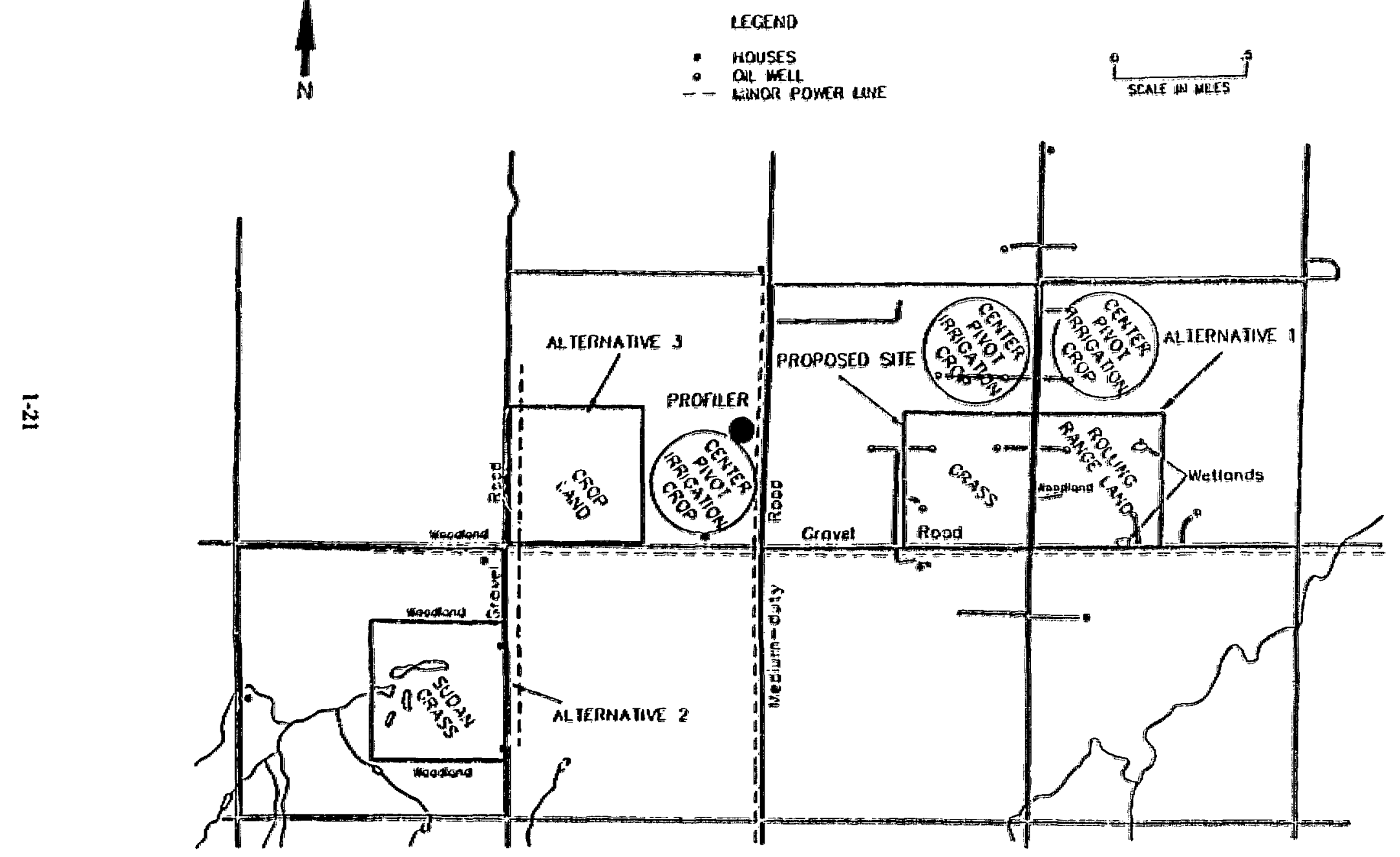

Figure 1.13 Siting of Boundary Facility in Kiowa County $=$ Ploposed Site and Alternatives 1,2, and 3 


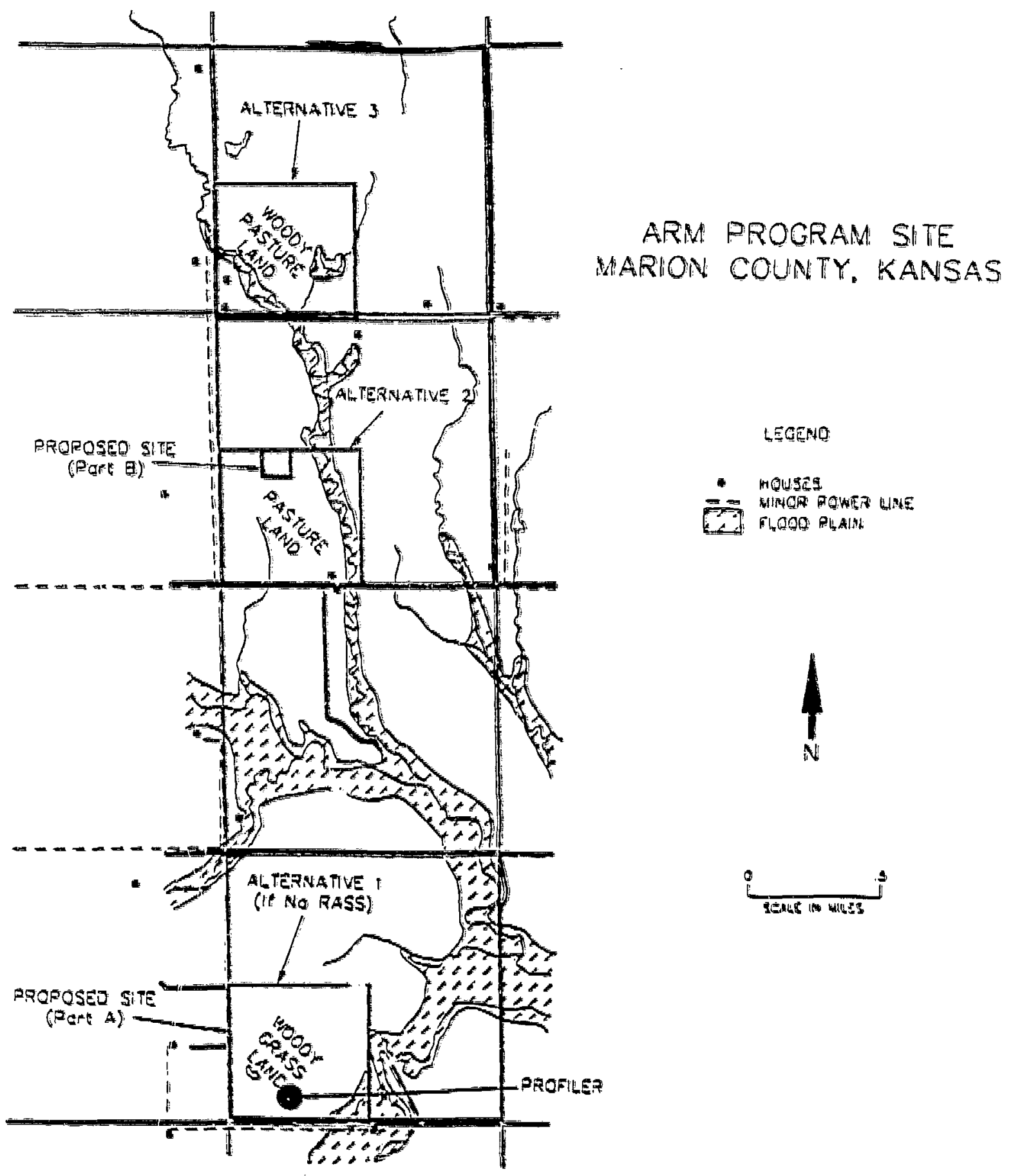

Figure 1.14 Siting of Soundary Facility in Marion County .. Proposed Site and Alternatives 1. 2 and 3 


\section{ARM PROGRAM SITE \\ MONTGOMERY COUNTY, KANSAS}

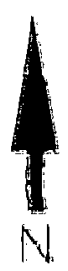

\section{LEGEND}
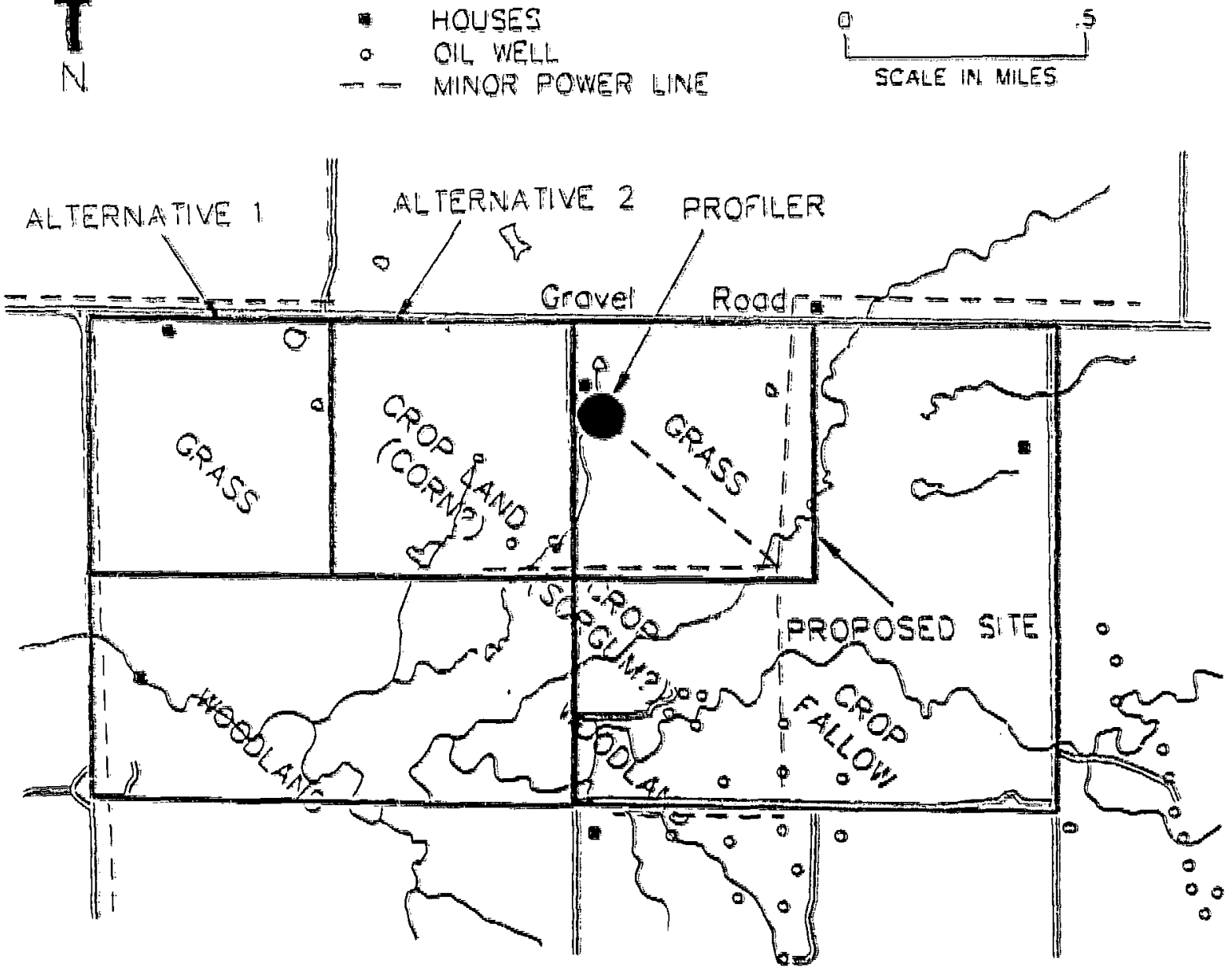

Figure 1.15 Siting at Boundary Facility in Me itgoningry County .. Proposed Sile and Allernatives 1 and 2 
Table 1.1 Legal Descriptions of the Proposed axd Alternalive Sites for the Central Facifity and Six Boundary Facilities

\begin{tabular}{|c|c|c|c|c|}
\hline Facilly. Location & Prcposed Site & Aiternativa 1 & Alternatwe 2 & Alternative 3 \\
\hline $\begin{array}{l}\text { Centrall Fecility, Larnont } \\
\text { Grant County, Oktahoma }\end{array}$ & $\begin{array}{l}\text { ME 14 Sectign } 35 \\
T=25 N, R-3 W\end{array}$ & $\begin{array}{l}\text { SE } 1 / 4 \text { Section } 26 \\
\text { T-25K, R-3W }\end{array}$ & $\begin{array}{l}\text { SW } 14 \text { Section } 35 \\
\mathrm{Y}-25 \mathrm{~N}_{2} \mathrm{~B}-3 \mathrm{~W}\end{array}$ & $\cdots$ \\
\hline $\begin{array}{l}\text { Goundary Facilily. Purcall } \\
\text { MeClain County. Oxkahoma }\end{array}$ & $\begin{array}{l}\text { NE } 1 / 4 \text { Sertion } 21 \\
\text { plus a } 1.75 \text { acre } \\
\text { parcel in the SW } \\
\text { corngr of Ah. } 3 \\
T=6 N, \text { R-3W }\end{array}$ & $\begin{array}{l}\text { WE } 1 / 4 \text { Seclion } 21 \\
\text { T-6N, R-3W } \\
\text { (if no } 50 \mathrm{MHz} \text { RASS) }\end{array}$ & $\begin{array}{l}\text { SE WH Section 2a } \\
\text { T- 6N, R-SW }\end{array}$ & $\begin{array}{l}\text { NW T/4 Section } 21 \\
T-6 \text { N. R-3W }\end{array}$ \\
\hline $\begin{array}{l}\text { Boundany Facility. Haskell } \\
\text { Okmulgee County, Oidahoma }\end{array}$ & $\begin{array}{l}N 1 / 2 \text { of } S E 1 / 4 \\
\text { Section 2, and } S 1 / 2 \\
\text { of } N E \text { 1/4 Section } 2 \\
T=1 S N, R=14 E\end{array}$ & $\begin{array}{l}\text { SW } 1 / 4 \text { Seclion } 1 \\
\text { T.15N. R-14F } \\
\text { (if no } 50 \mathrm{MHz} \text { RASS) }\end{array}$ & 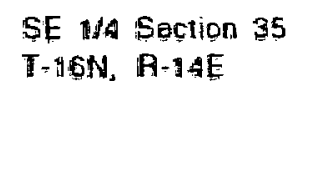 & $\begin{array}{l}\text { NE IA Section } 3 \\
\text { T-15N, R-14E }\end{array}$ \\
\hline $\begin{array}{l}\text { Boundary Facility. Vici } \\
\text { Woodward County, Oxlahoma }\end{array}$ & $\begin{array}{l}\text { NE 1/4 Section } 33 \\
\text { T-20N, R-20W }\end{array}$ & $\begin{array}{l}\text { NE 1/4 Section } 32 \\
\text { T-20N, R-20W }\end{array}$ & $\begin{array}{l}\text { NWW W/4 Section } 33 \\
\text { T-20N, R-20W }\end{array}$ & $\cdots$ \\
\hline $\begin{array}{l}\text { Boundary facility. Haviland } \\
\text { Kiowa Counly, Kansas }\end{array}$ & $\begin{array}{l}S E \text { 1/4 Section } 32 \\
T=27 S, \text { A-16!N }\end{array}$ & $\begin{array}{l}\text { SW U/4 Seclion } 33 \\
\text { Tr27S, R.16W }\end{array}$ & $\begin{array}{l}\text { SE 1/A Section } 1 \\
\text { T-2BS, R-17W }\end{array}$ & $\begin{array}{l}\text { SW 1/A Seglion 3A } \\
T+27 S, R-16 W\end{array}$ \\
\hline $\begin{array}{l}\text { aoundary Facility, Hillsboro } \\
\text { Maricn County. Kansas. }\end{array}$ & $\begin{array}{l}\text { SW } 1 / 4 \text { Gaetion } 14 \\
T=20 S, A=1 E\end{array}$ & $\begin{array}{l}\text { SW } 1 / 4 \text { Section } 2 \\
T-20 S, A=1 E\end{array}$ & $\begin{array}{l}\text { SW 1/4 Section } 35 \\
\text { T-19S, R-1E }\end{array}$ & $\cdots$ \\
\hline $\begin{array}{l}\text { Boundary Faciliy. Meodesha } \\
\text { Montgornery Counly. Kansas }\end{array}$ & $\begin{array}{l}\text { NW 1/4 Section } 2 \\
\text { T-31S, R=16E }\end{array}$ & $\begin{array}{l}\text { NW 1/4 Section } 3 \\
\mathrm{~T}=31 \mathrm{~S}, \mathrm{R}-16 \mathrm{E}\end{array}$ & $\begin{array}{l}\text { NE T/A Section 2 } \\
\text { T-31S, R. } 16 E\end{array}$ & $\cdots$ \\
\hline
\end{tabular}


2. The temporary rental or purchase of one or more small, trailer-like buildings to house the data acquisition systems and office work space, the placement of small sheds to store supplies, the placement of cement pads to provide a level base for several semi-trailers that would be used to house larger instruments, and the placemert of instruments and towers and anchoring. Such actions involve some clearing of land.

3. Continuous, around-the-ctock operation of instruments tor as long as ten years.

4. Routine (mostly but ast limited to daytime) overtlight with airbome sensors by aircraft (one aircraft tor a period uf $4-6$ hours approximately 2-3 days a month) mersuring cloud microphysical properties and solar radiation. Law-level flights, below FAA (Federal Aviation Administration) minimums, would nut be required.

In addition to these main activities, in one of more two- to three-week intensive experimental field campaigns, special studies would supplement the rneasuremerts at the fixed sites. These intensive periods woutd be cartied out mainly at the central fiutitity, but they could involve any of the factities. During this perich. the data collection fate from instruments would be increased. Activities would include labor-intensive measurements of meteorological variables such as eddy corretation to benchmark surface flux measurements of heat. moisture. and momentum. Prototype meteorological measurement instrumentation would be field tested. Because these activities are only temporary, no permanent structures would be required.

Aireraft operations activities during intensive experimental fiels cumpaigns wuld involve up to 6 research aircraft to provide solar ratiante and meteorological nbservations. The aircrant - (ortd range in size from light. single or twin propellet driven, to small. twin jet engine driven. W' lutge. multiple turbo propeller driven. The jet atrcraft woutd provide observations at the upper troposphere levels $(30,06)(7-50,00)$ tht), the larger aircratt at the middle croposphere levels $(1,500$ $30,000$ (t). and the light aircraft at the lowest troposphere levels $(500) \cdot 10,000 \mathrm{ft})$. Aircraft thight patterns would consist of horizontal transects at three levels: typically. the middle of the boundary tayer. the middle of the troposphere. and at the top of the tropospliere. There would also be zarticul profiling (spirats) from the boundary layer to the tup of the troposphere. During intensive experimental hield canpaigns, up to $4-6$ airchaft may be airbome simultaneously for approximately 4-6 hours. Aircraft activity during intensive periods would mostly be (but not limited wo within a $50 \mathrm{~km}$ radius of the central facility. For the flights 500 fi above ground level. light airctaft such as twitt-sngine propeller planes would be used and. vccasionally. an aircraft such as a P3-Oriun (four-engine turber propeller) might be used if the hight path would cover a sparsely populated area. The thight legs at $5610 \mathrm{ft}$ would mestly be (but not limited $(0) 20 \mathrm{~km}$ legs centered over the central factity. On one or two oecasions per year. a single criss-cross patern over the entire CART site at 5 (1) th maly be required and tight-atrcratt would be used for this purpose. All aircraft uperations witl be conducted according to all applicable FAA regulations. Aircraft conrdination is under way with Vance Air Force Base for use of Vance Military Operations Area I-B). FAA Kansas Cin Control Center. and Tinker Air Force Base. 
The auxiliary and extended sites have not been determined at this time because the scientitic criteria for their choice depends on fietd measurements acquired during the first few months of operation of the central facility. However, very minor impacts can be expected from these siles due to the low level of activity there and much reduced set of instruments that may have an impact on nearby residents. The siting of the extended and unxiliary sites is quite texible and would be chosen, based not only on scientific considerations, but also within the following environmental guidelines. All of these sites would be chosen to avoid areas with wetlands or flondplains; areas with the presence of any archeological sites or structures listed in the National Register of Historic Places of areas that have state-listed archeological sites or structures; areas with existing or planned land use tontrols or zoning that would prohibit the placement and gperation of such meteorological and radiation medsurement instrumentation: areas tri known habitats of threatened and endangered species or state-listed species; and areas with nearby visual resqures that somatin unique vistas. trails, national patcks, etc. The area within the CART boundary, in which such envirummentos criteria can be met, is very large and does att exclude any general area where placenent may be cinsidered.

Once the choive of atuxiaty and extended tacitises has been mate by the ARM setentists

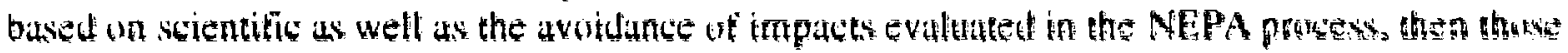
choices along with a briet description of NEPA-relatel isstes will be sent the approptate stule (Oktahoma of Kansas) for confirmation. Once such contirmation has been received by the ARM project and any required pernits obtained (it needed), then work at these sites may be initiated. It is likely that the choice of sites will be done in sequence. and so not afl sites will gon throbght this state review process at the same time. In addition. due to the thobusive activities planned at thene sites, it is expected that this review process will go smonthly. Letters th the states and the ir reply will become part of addenda to this EA.

\subsubsection{Instruments}

The instruments can be categorized into several grereps. In almost all cases. instruments would be remote sensors that contincously investigute the atmosphere in the verticial atirections. These instruments provide near-real-time data for evaluation of instrument pertomatede, model testing. and comparison with models. A sketch of the instruments currendy planned firr use an the central. boundary. auxiliary. and extended stees is given in Fig. 1.4. A more complete ulescripripum of instruments is given in Appendix C.

\subsubsection{Radiation Sensors}

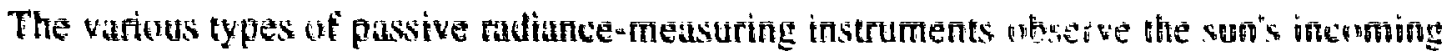
and , retgeng shortwave (light) and langwave (heat) radiation and the eartin's heat eomissurns. Radiation sensors would be used at all farilities. The high resolution radiation sensons ton he used

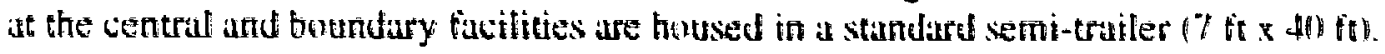




\subsubsection{Standard Mateorological Instruments}

Sensors of ternperature, relative humidity, pressure, rain amount, and wind sped and direction provide direct measurement of the atmosphere. They are usually mounted on a small. guyed tripod that is used to wise the sensons to the measurement height of $10 \mathrm{~m}$. Direct measurement oi heat tlux and moisture tlux at heights of $1-2$ m abuve the surface tequire an smatl pole-and-guy system. Soil temperature is medsured by a small therrmotrapte burted ul levels typically less than $15 \mathrm{~m}$ below the surtace. Standard meteogrtogion instruments would be used at all Eacilitics,

\subsubsection{ProllarglRASS}

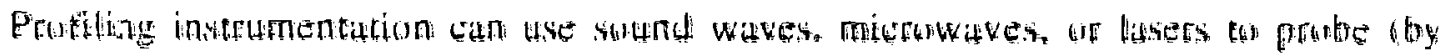

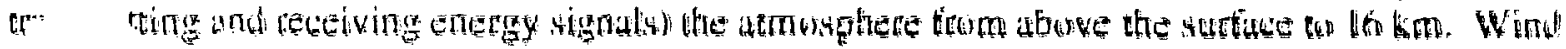

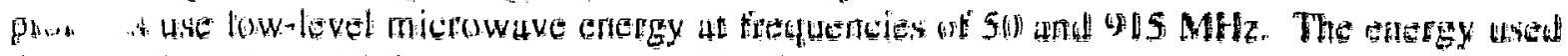

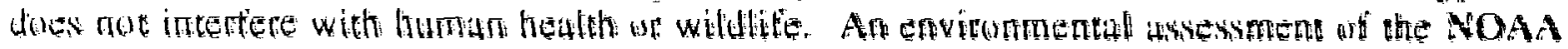

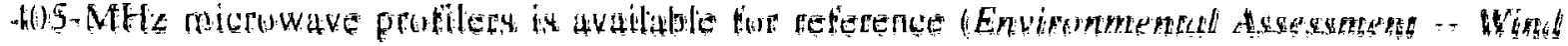

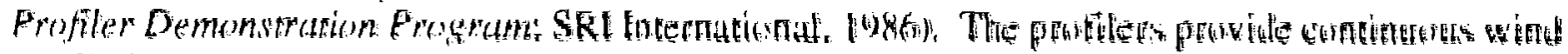

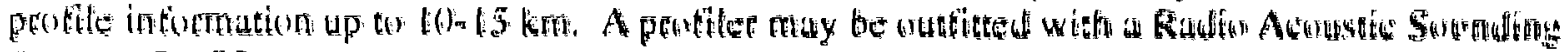

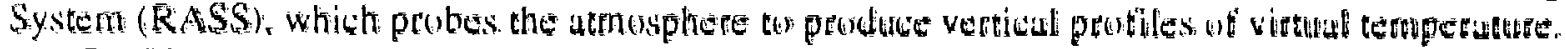

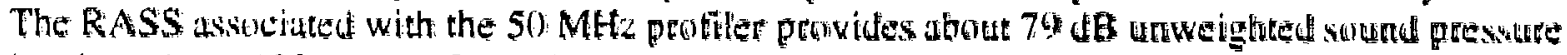

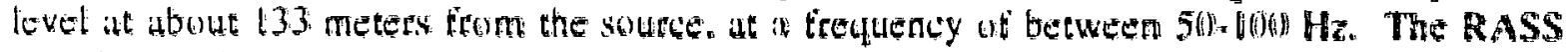

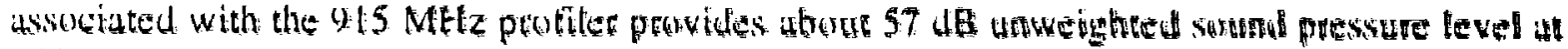

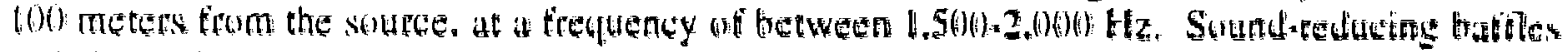

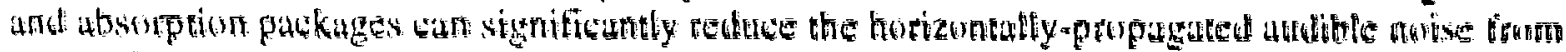

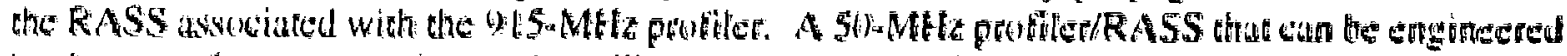

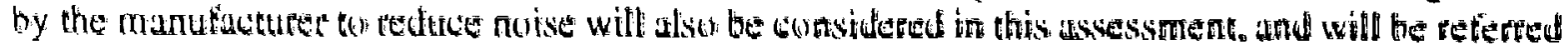

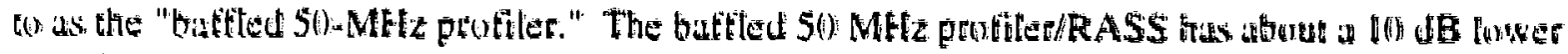

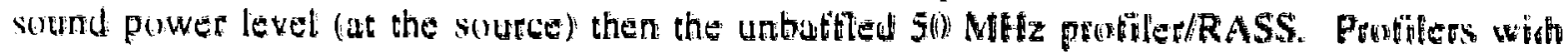

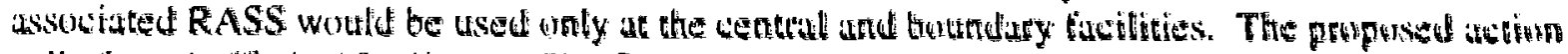

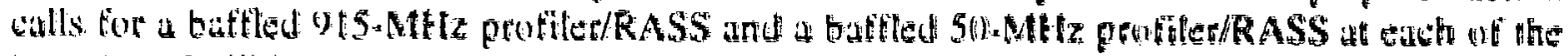

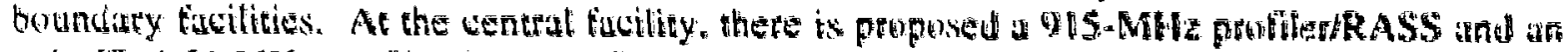

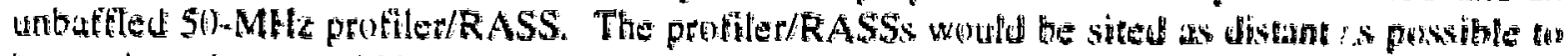

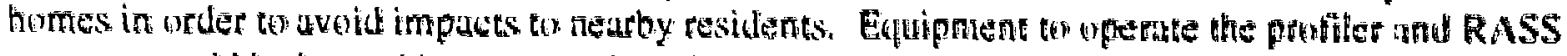
systems would be located in a standard semi-terter.

\section{J.2.4 Radars and klars}

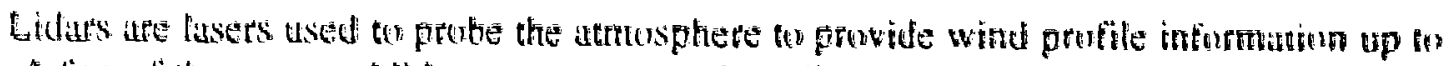

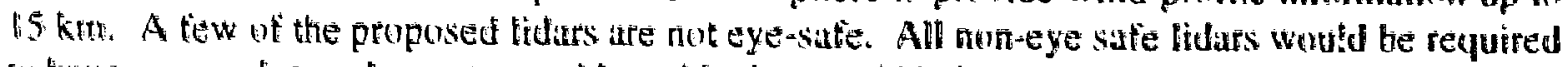

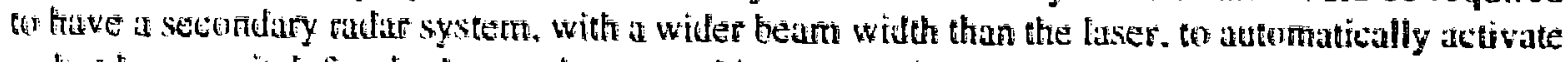
as shedsuwn switch for the laser when any object enters its path both on the surfice ur in the air. Livars woutd be used anty at the centrat factity and possibly at ane auxinaty facility. Shuuld a tidar be used at an aturitary taciticy. it will be of the eye sate type. or have a secondary safety radar 
system as descnoed above or will be manned during operational periods. Passive microwave radars would be used to probe the atmosphere for humidity at the central and auxiliary facilities. Ceilometers, eye-safe lidars used to measure the height of the base of elouds, would be used only at the central and anxiliary facilities. The lafger lidiur and rodiar systems would be housed separately in standard semi-trailers.

\subsubsection{Fawinsondes}

Rawinsondes are helimm-filled baltowns used to carry small metergological instrument packages up to I0 $\mathrm{km}$ in the earth's atmosphere. This type of ballown-burne system is used coutinely for medsurement of wind speed, direction. temperature. humidity, and pressure as it tunction of altirude by the National Weather Service fir its datly weather torecasts. Rawinsundes would be wsed unly al the central and boundury tacilities. Rawinsonde systems are conteined in an $8-t$ ti $\times$ l(t)-tk teailer.

The baltorn-bone system is equipped with a parachute to stow the decent ritte at the instrument package after the ballown breaks at high altitudes to less than $5 \mathrm{~m} / \mathrm{s}$. The instrument packgge will be labeled with intormation that identifles the instrument and provides an $80 \mathrm{~m}$ phone number to call for turther information.

\subsubsection{Plattorms and Facilities}

A 6 (b) m tower would be erected only at the central facility to provide standard meteorological and radiation measurements. Also at the centrat facility. normal office work space

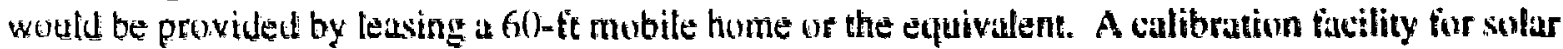
instrumentation would requite the leasing of a second 6li-fit mobile home or the equivalent. Several small storage garages (approximately $15 \mathrm{ft} \times 30 \mathrm{ft}$ at the central facility and $10 \mathrm{ft} \times 1 \mathrm{f}) \mathrm{ft}$ at each of the boundary facilities) and a small loading dic: would be required to unload and store sugplies. Utilities (power. water. phone. well and septic. etc.) would be rejuired to operate sompuers and instrumentation and for personnel at the central facility. Siting considerations instude close proximity to existing commerctal power lines so that connecting lines could be run to individual instruments. Every effort would be made to keep power lines short and cunfined (o) existing rights-ofl-way where possible.

In lisu of the offies trailer. an abandoned farm hutse exists on the guarter section of the proposed central tacility site. If tound to be structurally sound. repairs to the house may be more exonomically benefictul than leasing a . aler. The use of the house, since already in place, would pestuce the fortential impact by one large trater to the cencral facility.

Power requirements at the boundary. xtended, and auxiliary facilities would be much Lower than required at the central facility. Commercial power is preferred. but solar power/battery backup systems are considered a viable option for instruments at the extended and auxiliary fuctititis. Although routine visits would be required for maintenance. no permanent on-site presence wotld te requited at the extended. auxiliary. and boundary facilities. However. 
boundary tacilities would require the daily presence of personnel to launch rawinsonde balloons. Trailer space witt be made available for a place of shelter, a phone and desk, and bottled water at the boundary facility. One portible toilet will be supplied tor sanitation reasons.

Some of the instruments are large and cannot be hand-carried to the actual placement location. A small track will be required for installation and removal of equipment. Because of the scientitic concems about maintaining existing surface characteristics, portable mats laid down and picked up is a temporary path for vehicle traftic which minimize impact to surtaces may be used during instrument installation and removal. Instruments in the tield woukd be approached on fort or by as small all-tertain vehicle for all routine muintenance of instulled equipment.

Fences will be used to protect instruments trom wildlite and inadvertent entry by hum:ans. All bences will be labeled with appropriate warnings and/or intormation.

The placement of instrumentation at the centrat, boundary, auxiliaty, and exiended fatifities involves unly a small amount of construction activity that coufd lead to surtace disturbantes. In tact, the actual area involved in surtuce disturbances at each of these sites is very small. Appendix

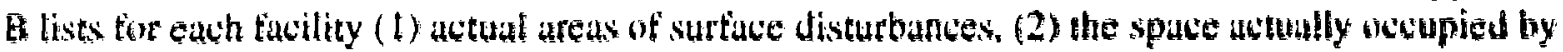
an instrument of facitity. and (3) the tenced area. For example. from Tuble B.5. the central tacility covers 160 acres. but only 1.83 acres of that amount would actually be disturbed. The remaining portion of the area in each of these fuctities (e.g., the semaining 160$)-1.8=158.2$ atres of the central facility) would not be disturbed and continue with its same land use. An inspection of Fig. 1.t reveals the relative sizes of the instrments and/or facilitie to be used. The larger fucilities are the (wo 10)-ft $\times$ 60)-ft mobile homes (br portable buildings) brought to the site and anchered there. One of the mobite homes provisies space for the computers. a small laboratory for un-site equipment repairs, and affice space tor 3-5 personnel. The other mobile home provides calibration space for the solar radiation instruments. A smaller shed and dick (15 fit $x 30$ fit at the centrat tacility and $10 \mathrm{ft} \times 15$ th at the boundary facilities) and about 6 semi-trailers $(7 \mathrm{ft} \times 40 \mathrm{ft})$ are also required.

The largest clearing rectuired is for the $50-\mathrm{MHz}$ profiler system. The procedure for placement of this instrument. semi-trailers. and mobile trailers is to level an area (which is already nearly tevel), remove the vegetation from that area by surtace scraping. apply two 6 -mil-thick plastic sheets at right angles over the scraped ground. plate about 3 in. of gravel on top of the plastic. and plate the profiter or trailer on top of that. Tie-downs would be used on hold mobile homes and trailers securely in place. At the central tacility. mobile homes would be transported to the site. or portable buildings would be brought to the site on a semi-trailer truck. The portable buildings and'ur storage sheds could be made of thberglass that has been prevonstructed ur molded we comprised of $2-3$ smatl mobile trailers or portable buildings. For the siorage sheds. the base wenta be a cement pad that exceeds the ground contact area of the building. Only one sma"t trat? ir (fir grading) would probably be used alung with a gravel dump truck and a cement mixer. These ptectes of equipment woutd move from one part of a site to another as one job is completed. A water truck would be used to minimize the fugitive dust.

At the central futility, utitities (water, power, telephone, etc.) twould be required, as would power and telephone at each of the boundary. auxiliary. and extended sites. Solar powver is 
curtently expected to power the instruments at the auxiliary and extended facilities (up to 31 sites in total). Some of the instruments require power and semi-trailers for housing. Thise include the Raman tidar, the scanning lidar, the infrared interterometer, the ceilometer, and the balloon-bome sounding system. A sketch of these systems and the relative sizes of semi-trailers needed to house them is provided in Fig. 1.4.

The decomraissioning plan, after the ARM tield work is completed, is to restore each of the disturbed areas to its previous usage. If, after the ten years of study are completed, the decision is made to maintuin the equipment at the sites longer (perhaps supervised by a university, for example $)_{n}$ a ce-evaluaton of environmentat imparts (on the basis of the ten-year experience) would be made through a new environmental ussessment the evaluate the impacts of any further experimental effort. Presently, decummissioning of the sites is expected at the end of the ten-year experimenzil study.

\subsection{No Actlon Alternatlve}

The no action aternative implies no work done wn the ARM projget installing und uperating meteorologicat instrumentation at any of the three U.S. Gocates. In particular, the no action alternative means that there would be no construction or operation of any instrumentation in Oklahoma or Kansas. No construction or operational air emissions. no noise impacts. no impacts to visual resources, no sociveconomic impacts, no impacts to cultural resources, etc. abowe current baseline levels. would occur. The current attected environment remains the sime. 


\section{Affected Environment}

This chapter witl describe the attected environment at the centrat facility and the six boundary tacilities. Nine key environmental areas will be evaluated: (l) soils and geology: (2) water resources; (3) air quality; (4) noise; (5) biotic resources; (6) land use; (7) visual resources; (8) cultural resources; and (9) socioeconomics. The focus will be on information that is required Eof later assessment of the impacts of the proposed action and its altematives in Chapter 3.

\section{2.t Solls and Geology}

\section{2.t.t Grant County, Oklahoma, Central Facility}

At the proposed site in Grant County. the sotl is predominantly Kirkland silt loam. with

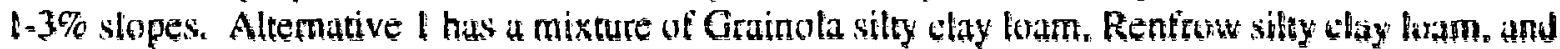
Kirkland silky loam. Altemative 2 has mainly a mixture of Kirkland silty loam und Rentrow silty clay loam. These sot types are in the Renfrow Grainota association ta groug of soils commonly found together): i.e.. they are deep or moderately deep. very gently stoping to gently sloping. well drained, nonalkali soils that have a loarny surtace layer ovet a clayey subsoil, usually found on uplands. Due to the fact that these soils have a low permeability as an absoption field. a large septic tank field that services large facilities with many people ure not permitted. The geology of Grant County is tairly simple. Outcropping rocks consist of Permian sandstones und shales that were deposited near the shoreline of shallow seas that once covered much of westem Oklahoma. In many parts of the county, these rocks are mantled by unconsolidated alluvium laid down by modern rivers and streams.

\subsubsection{MeClain County. Oklahoma, Boundary Facllity}

At the proposed and alternative McClain County boundary sites. the soils are predomunantly Lela slay and Port sit loum. The general suil/reliet/drainage type is Nash-LucienGrant. which reters to well drained soils that are laamy throughout, formed in residuum from sandstone on uplands. Such an area has fair potential for residential or other urban use. Slopes in excess of $8 \%$ and bedeck of a depth of less than 40 in. limit the development of some fteilities.

\subsubsection{Okmulgsa County, Oktahoma, Boundary Facility}

The proposed site. at Okmulgee County. is mainly a mixture of Collinsville-Talihina complex (with 10.30\% slopes) and Bates-Collinsville fine. sandy loams (with 1-5\% slopes). Alternative I has a combination mainly of the Bates-Collinsville fine sandy loam and the Hector complex $(5-30 \%$ slopes). Alternative 2 has mostly Hector-Hartsells tine sandy loams. Alternative 3 has predominantly soil of the Hector complex (5.30\% slopes), which is soil that is lerarty, siticeots, and thermic. The more clayey soils tend to have more movement and tend to 
shrink and till more during summertime and wintertime than loamy soil. These tendencies would have an impact for large facilities. The geological formations that are at the surface or immediately beneath the soil in Oknulgee County are of sedimentary origin. Except for Recent alluvium and Quaternary terrace deposits. these formations belong to the Pennsylvanian system. The Pennsylvanian formations consist mainly of sandstone and shale.

\section{2.t.4 Woodward County, Oklahoma, Boundary Facility}

The predominant soil type foc the proposed boundary site and both alternative sites in Woudward County is Prute tine sandy toam. The Pratt association is made up of deep sandy soils that have tormed under native grass. Sand sagebrush is common. and a tew trees oceur in swme wreas. The deep, brown, sandy Prut soils are un undulating to low dunelike topography in the uplands. They have a surtace layser of brown tine sand or tormy tine sund and a subsoil of yellowish brown toamy tine sand. The suil absurbs muisture well.

\subsubsection{Klowa County, Kansas, Boundary Facllity}

The main soil type at the Kiowa County proposed boundary site and the aftemutives is the Pratt loamy fine sand. The Pratt-Attica association consists of deep. undulating and rolling. well drained soils that have a sandy or loamy subsoil and are on uplands.

\subsubsection{Marion County, Kansas, Boundary Facilly}

Each of the Marion County boundury attemutives is in the Gorssel-Rosehill assuciation. implying that the soil area is moderately deep or deep, is nearly level and gently sloping. is moderately well drained. has a clayey subsoil. and is on uplands. The main soil at the proposed site and Alternative $I$ is Irwin silty clay loam. Alternative 2 has Irwin silty clay loam and Wells loarn. The trwin series consists of deep, moderately well drained, very stowly permeable soils on uplands. These soils formed in old allevium. The Wells series consists of deep. well drained. moderately permeable soils on uplands. These soils fomted in old alluvium or in residuum from noncalcareous sandstone.

\subsubsection{Montgomary County, Kansas, Boundary Facility}

The Montgomery County boundary fatility site is part of the Verdigris-Osage-Lanton assoctation with nearly tevel. moderately well drained to ponrly drained. silty and clayey soils on buttem land. The main soif type for the proposed site and the altematives is the Bates-Collinsville complex ( $1-4 \%$ slopes). which consists of gently sloping. well drained soils that are on the tops of ridges in the uplands. The Bates soil is suitable as a site for dwellings without basements and for local rouds and streets. However. Collinsville soil is not suitable as a site for dwellings and local roads and strests, becuuse the depth to rock is a severe limitation. 


\subsection{Water Resources}

\subsubsection{Surtace Water Quality}

\subsubsection{Grant County, Oklahoma, Contral Facility}

The proposed site of the Central Facitity is in the basin of the Salt Furk of the Arkansas River. A total of 529,250 acre-feet of water is avalable. Many areas of Grant County have an inadequate water supply for domestic and livestock use. Rural water systems presently serve much of Grant County. Water tơ these systems and for limited irigation is available under some of the butom land soils. In some areas, the water is too high in salt and mineral contents for domestic use. Farm ponds tumish meth of the water for livestock.

The area of north central Oklahoma in which Geant County is loested is part of the Enid quadiangle. which is within the Arkangas Rver basth. The nearby Salt Fobs of the Arkansas River is one of severat rivers and tributaries that arke up the dwinage netwok for most of the region. Restrictions have been imposed on the use of water fim majof strams in the area for public water supplies and some types of industrial and agrictultural uses becuse of excessive concentrations of sulfate, sodium, and chlotide. These constituents cume mainly from gypsum and salt-bearing tormations west of the ared.

\subsubsection{McClain County. Oklahoma. Boundary Facllity}

The propesed McClain County boundary kateitity is near Finn Creek. which is a tributiry of the Middle Washita River Strean System Basin. A total of 227.320 acre-teet of water is avaitable.

\section{2.t.3 Okmutgee County, Oklahoma, Boundary Facillty}

The proposed Okmulgee County boundary tacility is near Duck Creek and Snake Creek. which are tributaries of the Middle Arkansas River Stream System Basin. The total water available has not been determined. Rainfall is about 38 in. per year. with about $60 \%$ of the average annual taintalt occurring during the growing season, from April to September.

\section{2.t.4 Woodward County, Oklahoma; Boundary Facility}

The proposed Woodward County boundary facility is near the South Persimmon Creek. which is a tributary of the Upper North Canadian River Stream System. In all. 24.400 acre-feet of water is avatable. Surface water quality (for minicipal use) is rated poor. with more than $1 .(1010 \mathrm{mg} / \mathrm{L}$ of dissolved solids in nearby Brent Creek. 


\section{2.t.5 Kiowa County, Kansas, Boundary Facility}

The area of the proposed and alternative sites in Kiowa County, which is the upper Arkansas drainage basin, is drained by Rattlesnake Creek and its tributaries. Annual precipitation is about $23 \mathrm{in}$. and of this 16 in. fall in April through September.

\subsubsection{Marion County, Kansas, Boundary Facility}

The Cottonwood River and is tributaries deain about two-thirds of Marion County trom nurthwest to southeast. Areas along the souttern part of the county (where the boundary facility would be locuted) are drained by Middle Emma Creek. Eutst Emma Creek, Sand Creek. and Turkey Creek, which flow south. Sources of surtace water are ponds, springs, lakes, and perennial streans.

\subsubsection{Monigomery County, Kansas, Boundary Faclliky}

Most of Mongomery County is drained by the Verdigris and Elk Rivers and their tributaries. These streams flow in the southerly direction. The water for use on farms is drawn from wells, ponds, , itreams, and rural water district supply lines. The water tor towns generally is drawn from streams and lakes.

\subsubsection{Groundwatör Quality}

\subsubsection{Grant County, Oklahoma, Central Facility}

The proposed Grant County sites are in the Vamoosa aquiter. which is composed of fineto coarse-grained sandstone irregularly imbedded with shale and limestone. Wells in the ayuifer generally yield 25-50 gallons per mintute (gpm). The chemical characteristits of groundwater in that area differ considerably within short distances. The water in the area is typically hard or very hard and locally contains sulfate and chloride in excess of $250 \mathrm{mg} / \mathrm{L}$. The total dissolved solids concentrations in the groundwater in the Vamoosa ajuifer are $5010=1.010 \mathrm{mg} / \mathrm{L}$.

\subsubsection{Meclāin County, Oklahoma. Boundary Facillity}

The chemical quatity of the groundwater in McClain County is generally good, with dissolved solids contents of less than $500 \mathrm{mg} / \mathrm{L}$. which is satisfactory for most uses. An undestrable constituent or excessive hardness may make the water unsuitable for some purposes. However. the yield is expected to be less than $25 \mathrm{gpm}$. 


\subsubsection{Okmulgee County, Oklạhoma, Boundary Facillty}

This area of Okmulgee County proposed for sting the boundary facility is generally unfavorable for groundwater supplies. The ares is undertain by shale, siltstone, and sandstone of Pennsylvanian age and by terrace deposits. Most wells in the shale, siltstone, and sandstone yield only a fraction of a gallon per minute to a few gallons per minute. Wells here yield timited amounts of water of poof quatity.

\subsubsection{Woodward County, Oklahoma, Boundary Facility}

Groundwater in the Woodward County area is derived atmost entirely trom the precipitavion talting directly on the ared. Of an anmul precipitation from $21-28$ in., about \$.7-2.2 in is available annually to gecharge the groundwater geservoir. A well in the area of the boundary tacility could yield $25-150 \mathrm{gpm}$. Water in this area is derived mostly from the thin sand and gravel of some altuvial and terrace deposits, the Ogallaia Formation. and some pats of the Whitehorse Group. The chemicall quality of the groundwater in these areas is generally gokd. with total dissolved solids contents typically less than $506 \mathrm{mg} / \mathrm{L}$.

\subsubsection{Kiowa County, Kansas, Boundary Facility}

Water in sufficient quantity for irrigation is availuble in the northern part of the county. where the proposed site alternatives are located. The use of irrigation systems has increased significantly in the sounty over the past 20 yetrs. Domestic and livestock water generally is obtained trom wel's. A welt dug in 1981 about two miles trom the proposed sites encountered groundwater 40 fo trom the surface. A 123 - ft well yielded $1.400 \mathrm{gpm}$ (Kraxner. $1991 \%$. Woter in that general area is themically suitable for irrigation (Fader and Stullken. 1978).

\subsubsection{Marion County, Kansas, Boundary Faclity}

Groundwater in Marion County is generally of poor quality and low yield. Wells that yield $100-500 \mathrm{gpm}$ are in the central part of the county. (The boundary tacility is in the west central part of the county.) Wells in the rest of the county yield $10.1110 \mathrm{gpm}$. About 2.600 acres of cropland are irrigated. Water for several irrigation systems comes from wells. A tew systems depend on water from streams. but the water supply from streams is limited. and water often is net available when it is needed. In places, the supply of water from wells is inudequate for domestic and livestock use. Rural water districts have been formed. and three of these are presently in use. 


\subsubsection{Montgomery County, Kansas, Eoundary Facility}

The proposed site and the alternatives in Montgomery County overlie Chanure Shale and Drum Limestone. Sandstone beds in the Chanute Shale are an important consolidated-rock aquiter that yields small to moderate supplies of water to wells trem sandstone beds at depths of as much as 400 ft Drum Limestone genefally yields litte or no water to wells except in the shallow zone of weathering. A well in the area near the proposed sites yields water with a dissolved solids content of $183 \mathrm{mg} / \mathrm{L}$ (OConnor. 1974). Kansas drinking water standards for dissolved solids are $500 \mathrm{mg} / \mathrm{L}$.

\subsubsection{Wotfands}

Marshes, swamps, punds. and bugs are used by migratory birds, tish. and atpuatic plan! life. Wetlands have the following benetits (Federal Interugency Commintec. IV8\%):

1. Protection ot wildlite. Wethands support $30 \%$ of tederally protected threstened and endangered species. Wetands can be shatlower. less turbutent areas for tish to hatch: they are a sate refuge for amphibians and reptiles. Wellands are the tew tertile, moist areas during winter for migratory birds and are crucial waterfowl nesting spots.

2. Control of thouding. Wetlands act as holding tanks during heavy rains and snow melts.

3. Purification of water. Weth'7us tilter sediments and golltatants before water hows to nearby streams, lak $\therefore$ and rivers.

4. Boosting of grutundwater supplies. Wetands help purify and replenish water supplies by recharging aquifers and hitrering: out sediment and disease-causing bacteria.

Wetlands are protected by the Clean Water Act ot 1977 (33 U.S.C. 1251 et sey.). Any soif disturbance in a designated wetland area is construed as depositing fill in the waters of the United States, and wetlands are considered part of the waters of the United States. Any proposed digging activity in a wetands area reguires application for a Section 404 permit or a waiver of a permit trom the U.S. Army Corps of Enginesers.

Each central facility site and the six boundary facility sites (proposed sites and altematives) were evaluated with regard to wetland sites. Documents reviewed were (1) Soil Conservation Service wetlands maps. (2) U.S. Fish and Wildtite Se:vice National Wetlands Inventory Program maps and (3) data obtained from the U.S. Army Corps of Engineers in Tulso (for the northem Oklahoma and southern Kansas sites). All letters documenting the findings of the various agencies cited throughout Section 2 are provided in Appendix $D$. 


\subsubsection{Grant County, OkJahoma, Cantrat Facility}

The U.S. Fish and Wildlife Service investigated the presence of wethands in the proposed and altemative quarter sections of Grant Cusmy inul found no wetands. Furthemore. the U.S. Soil Conservation Service wetlands maps indicated that there are no wethunds at these sites.

\subsubsection{Mcclain County, Okfahoma. Boundary Faeility}

The evaluation by the U.S. Fish and Wildtife Service and the McClain County Soil Conservation Service indicated that all ot the altematives for the MeClain Cumby boundary tacility have protected wetlands in the quinter sections. No wetlands appear to be in the proposed site. The wetand area is illustrated in Fig. 1.10. The creek wriented north-south needs to be protected

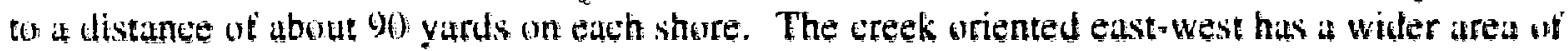
protedion toward the east side. In the case of the MeClain County boundary tacility. the wethad area concides with the koodplain area to be fiscussed in Section 2.2 .4$.

A letter from the U.S. Fish and Wildtite Service conceming the wethonds athis buthdary facility recommends that impacts to wethand and stream areas (the thowdplain be avoided by locating tacilities in upiand sites.

\subsubsection{Okmulgeo County, Okfahoma, Boundary Facility}

While the U.S. Sorl Conservation Service wetlands maps indicated that thefe were no wetands at these sites, the U.S Fish and Wilutite Service determined that there are wetlands in the alternative sites 1 and 2 quarter sections in Okmulges County.

A latter from the U.S. Fish and Wildite Service conceming the wetlands at this boundary facility recommends that impacts to wethands and stream areas (he thouplain) be avoited by locating facilitios in upland sites.

\subsubsection{Woodward County. Oklahoma, Boundary Facllity}

The U.S. Fish and Wilatite Service investigated the presente af wethands in the propused and alternative quarter sections of Woodward $C$ oungy and found no wetlands of concern. Furthermore. the U.S. Sutl Conservation Service wetlonds maps indicated that there are no wethads at these sitas.

\subsubsection{Kiowa County. Kansas, Boundary Facility}

The U.S. Fish and Wildlife Service investigated the presence of wetlands in the proposed and alternative quarter sections of Kiowa County and found no wetlands of concem. 


\subsubsection{Marion County, Kansss, Boundary Facility}

No wetlands information was available for this site since the county has not been mapped for wetlands.

\subsubsection{Monigomary Gounty. Kansas, Boundary Facility}

No wetands information was available for this site since the county has not been mapped tor wetlarids.

\subsubsection{Floodplaing}

Ftoodplain/toodway areas are delineated by the Federal Emergency Management Agency (FEMA) tor the creks and bodies of water in eath county. Floodplain data were obtained from the U.S. Arryy Corps of Engineers in Tulsa tor the northem Oklahoma and southem Kansas sites. Each county in Oklahoma also sent verification information on floodplains for the proposed site and the alternatives in that county. The 100 kyear floodplain maps used for this $\mathrm{EA}$ are defined by FEMA and represent the regutatory floodplain for non-eritical fucilities to be observed by federal agencies, accorting to Executive Order 11988 (Floodplain Management, May 24, 1977). In an area marked as part of a 100 -year thoodplain. the probability of a tood is $1 \%$ per year. The toodplains would be avoided tor placement of any instrumentation.

\subsection{4.t Grant County, Oklahoma, Contral Facllty}

A review by the Grant County Conservation District and the U.S. Army Corps of Engineers in Tulsa revealed that no thodplains are in the area of the propused site and its altematives in Grant County.

\subsubsection{MeClain County, Oklahoma, Boundary Facllly}

A review by the McClain County Conservation District and the U.S. Army Corps of Engineers in Tulsa revealed that the proposed site und auch of the altemative quarter sections in MeClain County is partially encompased by thoouphain areas (see Fig. 1. 10).

\subsubsection{Okmuigee County, Oktatioma, Boundary Facility}

A review by the Okmulgee County Conservation District and the U.S. Ammy Coms of Engineers in Tulsa revealed that the quarter sections representing altematives 1 and 2 in Okmulgee County partially encompass floodplain areas (see Fig. 1.II). 


\subsubsection{Woodwand County, Okfihoma, Boundary Facility}

A review by the Woodward County Conservation District and the U.S. Amy Corps of Engineers in Tulsit revealed that no loodplains are in the area of the proposed site and its alternatives in Wondward County.

\subsubsection{Kiowa County, Kansas. Boundary Facility}

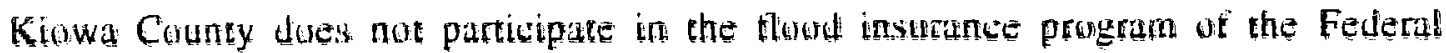

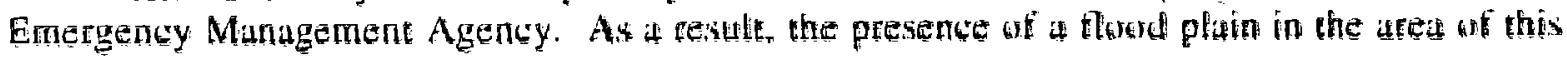
Eroject is very unlikely.

\subsubsection{Mation County, Kansas, Boundary Facility}

A review by the U.S. Army Corps of Engineers in Tulsatevealed that the propused and

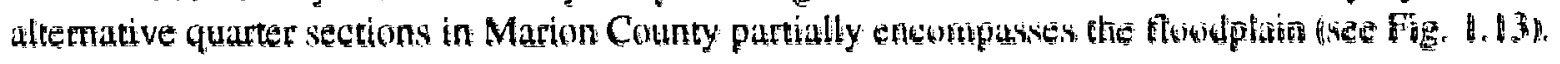

\subsubsection{Montgomary County. Kansas. Boundary Facilliy}

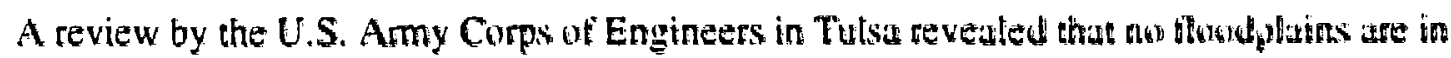
the area of the proposed site and its altematives in Mongonery County.

\subsection{Air Qually}

The swates of Okluhoma and Kansas ascept the National Ambient Air Quafity Stundade fut the following six criteria air pollutants: sultur dioxide. carbon monoxide. niteogen oxides. particulate matter. Ead. and ozone. Each stute has a limited monitoring network within the state to monitor compliance in areas that may be exceding one or more stundards.

The proposed central tacility in Grant County. Oktahoma. and the the propersed boundary sites in Oklahoma are in attanment areas for all air pollutunts. Most of the state of Oklahoma is an

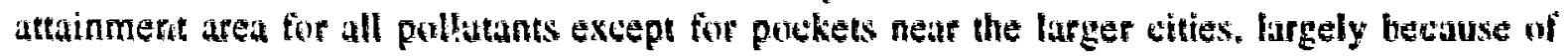
automobile exhaust. The entre stute is an attainment area except that $(1)$ for ozone. an exceedance exists in Farn. Tuls. and Skiatook. and (2) for sulfur dioxide. an excedance exists in Panca Cify. The state generalty places sampling stations where it expects that excedances of the criterit pollutants might occur. No sampling station exists in any of the four Otifhoma coumtes on interest beciuse significunt industrtalization and/or automobile tattic are absent.

All three of the boundary sites in Kaisas are in attainment areas for all pollutants. That is 10: be expected because none of the three areas is near a large city or a highly industrial area. Only the Kartsas City area in the notheast comer of the statel is a nonatainment area for carbon 
monoxide. The Wichita area is a nonattainment area for ozone. Otherwise the remaining portion of Kansas is an antainraent area with respect to each of the criteria poltutants.

\subsection{Nolse}

The ambient background (environmental residual) noise level at the proposed central fucility and each of the six proposed boundary facilities is expected to be law because industrial and

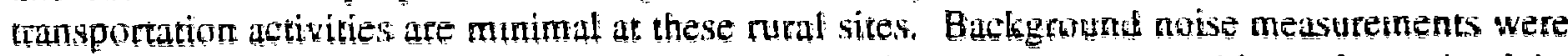
frade by Argonne National Labotatory staff for this EA at the nearest residence for each of the propored sires, at the two alternatives for the centad fucility site. and at two of the six proprosed boundary sives (Okmulgee County and Montgomary County M. Masurements were made in the evenifg or nightime, when human activity was at a ninirnem und suface winds were towest. The methodology used to measure the armbent noise levels at the sites is dencribed in Appendix $\mathbf{E}$.

The ambient nouse measurements in the full $1 / 3$ - tictave band spectum were atquired and

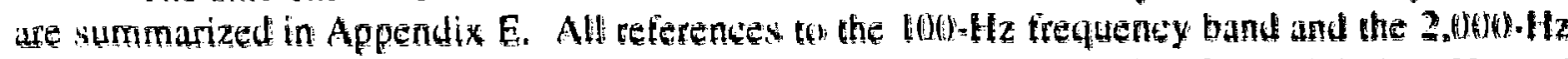

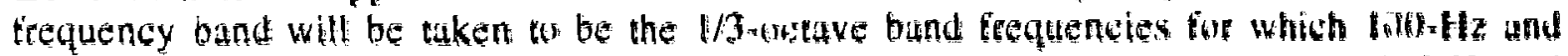

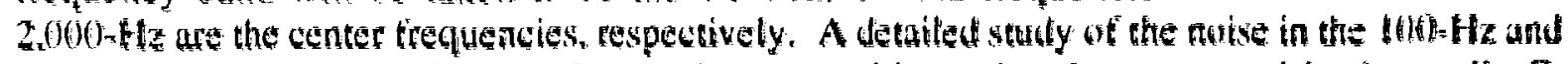

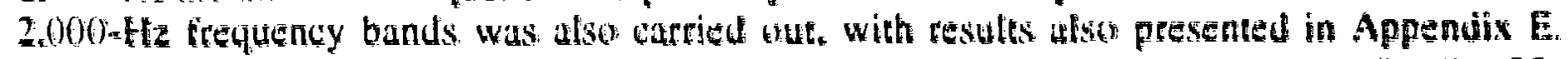
Emphasis is placed on these frequency bands because the 5 6)-MHz and $915-\mathrm{MHz}$ protiler/RASSs emit potentially annoying tones at those frequencies. Measured noise levels are compared with the threshold of hearing. which is detined as the lowest tevel that can be detected by the human ear.

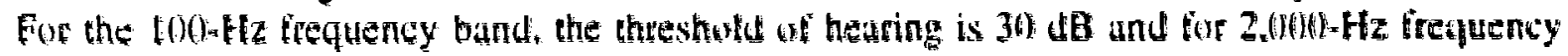
band the threshotd of hearing is 2 dB (Robinston and Whitle. 1964). A brief discussion of measured of expected noise levels at each site is presented here. The expected impars from the noise of the RASSs will be discerssed in Section 3.4.

Table 2.1 gives the distance between the proptised/altemative sites and the nearest residence for the central facility and each of the 6 boundary facilities. A zero in the duble indicates that the nearest residence is actualty on the plot of land that is represented by the proposedraltemative quarter section or immediately adjacent to it. Background .mbient noise levels are of interest for these nearest residences becusue the potential impacts whuld be gratest there. Field measurements carried sut tor this EA tocused on those nearest residences.

\subsubsection{Grant County, Oklahoma, Cantrat Faellity}

Background noise measurements were made in November and December 199 ! at the residences nearest the lacition of the propersed site and euch af the two alternatives in Grant County, as sketched in Fig. 1.9. The area around the propused centul facility is in an isolated fural area with furmhouses tocated within about a mile of each other. Most of the area is eitler cropland or pasture with some trees. Billings. Oklahoma, the nearest town. is ahout four miles to the south. Transportation traffic is rare during the evening and nighttime, ant? no industrial activity is present in the drea. Ambient noise levels are very low. Measureme'ts at the $100-\mathrm{Hz}$ frequency 
Table 2.1 Distance of Closest Fesidence to Each of the Proposad and Altennative Sites (miles)

\begin{tabular}{|c|c|c|c|c|}
\hline Facillity & $\begin{array}{c}\text { Proposad: } \\
\text { Site }\end{array}$ & Alt. 1 & Alt. 2 & Alt. 3 \\
\hline Grant County. OK & 1.7 & 1.5 & 1.5 & $\cdots$ \\
\hline Meclain County, oK & $a$ & a & 0 & 0 \\
\hline Okmulgete County, OK & 0 & 0 & 0 & 0 \\
\hline Woodward County, OK & 0.1 & 0.1 & 0,1 & $\cdots$ \\
\hline Kiowa County, KS & 0.1 & 0.2 & 0.0 & 0.1 \\
\hline Marion County, KS. & 0 & 0 & 0 & 0 \\
\hline Montgomery County, kS & 0 & 0 & 0 & $\cdots$ \\
\hline
\end{tabular}

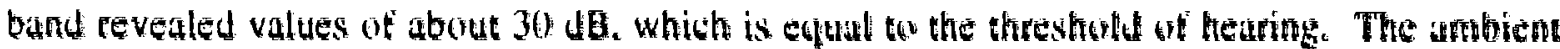
residuat noise level for the $2,000-\mathrm{Hz}$ trequency band is 8 (DE. Which is 6 UB higher than the threshold of hearing for this frequency band.

\subsubsection{McClain County, Oklahoma, Boundary Facilty}

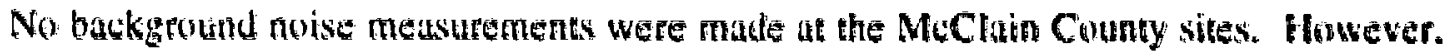
the background (environmentat restutul) nove levels are expected to be slightly higher than thuse meastred in Grant. Montgomery. and Okmulgee Counties. due to the fact that there is some industrial activily present. An obl plant runs continuously and the noise from that plant ean be heard at the nearest restdences during the nightime and sumetimes durring the day. Figute 1.10) presents a sketeh of the McClain County bountary sites and the residences nearest them. inciuding the vil plant. The area areund this boumary facilizy is isolated and rural. Residences are lowed close to the proposed site and Altematives I and 2. Transportation tratfic is fare during the evening and nighttime. Most of the ared is either sropland or pasture hand with some trees. By

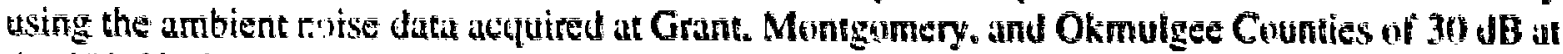

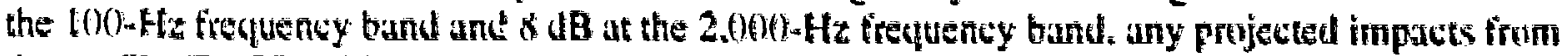
the proftler/RASSs wilt be overestimated since the background noise level at this site is expected to bo higher than at either Grant of Okmutgee Countes (due to the buskgetund nuise from the wil plant).

\subsubsection{Okmulgas County. Oklahoma, Boundary Facility}

Backiround noise measuremens were made in December 1991 adjacent to the residences nearest the location of the proposed site and each of the three alternatives in Okmulgee County. These locations are identitisd in Fig. 1.11. The area around this proposed boundary facility is 
rural, with residences located near to the north. east, and south of the site. Fewer homes are in the areas of the altematives than at the proposed site. However, residences are near all of the sites. Transportation traffic is fare during the evening and nightime, and no industrial activity is present. Most of the area is either cropland or pasture land with some trees. Measurements at the $100-\mathrm{Hz}$ frequency band reveated values about $30 \mathrm{~dB}$, which is barely audible. The ambient level at the $2,000-\mathrm{Hz}$ trequency band is $10 \mathrm{~dB}$, about $8 \mathrm{~dB}$ greater than the threshold of hearing.

\subsubsection{Woodward County, Oklahoma, Boundary Facility}

No background noise measurements were made at the Woodward County sites. The propaced sife and the two alternatives are sketched in Fig. 1.12. Background noise levels are expected to bery low at this site because the area has no nearby industrial artivity and liule uansportution activity. The background noise levels are expeded to be similer to those measured in Grank Montgomery, and Okmulgee Counties becuuse the land use and density of houses are similar. Figure 4.12 presents a sketeh of the lacation of the residences nearest the three sites under consideration. The area around this propowed boundary tacility is rural. Residences are lowated nearby to the north. west. and south of the site and altematives. Trunsportation traftie is rure during the evening and nightime. and no industrial activity is present in the area. Most of the area is rolling rangetand. Ambient noise data acquired at Grant. Montgomery. and Okmulgee Countes suggest that the ambient noise level in the 100-Hz frequency band should be ahout $30 \mathrm{JB}$. The ambient level at $2.000(-\mathrm{Hz}$ is expected to be about $8 \mathrm{JB}$.

\subsubsection{Klowa Gounty, Kansas, Boundary Facilly}

No backgroand noise measurements were made at the Kiowa County sites. Background noise levels are expected to be very fow at these sites becouse the area hak no nearby industrial activity and little transportation activity. However. the background noise levels are expetted to be similar to those measured in Grant. Montgomery. and Okmulgee Counties. Figure 1.13 presents a sketch of the loctation of the Kiowa County proposed and alternative sites and the residences nesrest them. The ared around this boundary facility is rural. Only a few residences are located near the proposed site and alternatives. Transportation traffic is rure during the evening and nighthime, and no industrial activity is present in the area. Most of the area is cropland, rolling fangeland. and geassland. Ambient noise data acquired at Grant. Montgomery, and Okmulgee Counties sugkest that the ambient noise level in the $100 . \mathrm{Hz}$ frequency band should be about 30 $\mathrm{JB}$. The ambient level in the $2.0000-\mathrm{Hz}$ frequency bund is expected to be about $8 \mathrm{~dB}$.

\subsubsection{Marion County, Kansas, Boundary Facility}

No background noise measurements were made at the Marion County sites. Background noise levels are expected to be very low at the proposed and alternative sites because the area has no nearby industrial activity and little transportation activity. However. the batkground noise levels are expected to be simitar to those measured in Grant. Montgomery. and Okmulgee Counties. Figure 1.14 presents a sketch of the Marion County boundary sites and the residences 
nearest them. The area around this boundary facility is rural. Residences are located near the proposed site and altematives. Transportation traftic is rare during the evening and nightime, and no industrial activity is present in the urea. Most of the area is woudy pasture or woody grasstand. Ambient noise data acquired at Grant. Montganery, and Okmulgee Counties suggest that the ambient noise level in the 100-Hz trequency bind should be about $30 \mathrm{~dB}$. The ambient level at the $2,000-\mathrm{Hz}$ frequency band is expected to be about $\mathrm{S} \mathrm{AB}$.

\subsubsection{Montgomery County, Kansas, Boundery Facility}

Background noise measurements were rate at the Montgomery County sites. Backgrmund (cnvironmental residual) noise levels were very low at the proposed and alternative sites becanse this area has no nearby industrial activity and little transportation attivity. Figure 1.15 presents a sketch whe Mungomery County butndary sites ind the residences nearest to them. The area around this boundary bitility is rurat. A few residences are lowated close th the propused site and the altefnatives. Trunspottation trattic is rare during the evening and righthine, and no industrial activity is present in the area. Most of the area is cropland of gatsolund. The ambient noise level at

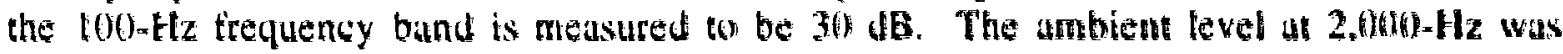
medsured to be $6 \mathrm{~dB}$.

\subsection{Biotic Resources}

In terms of areat requirentents, the ARM Program's CART site $(325 \mathrm{~km} \times 275 \mathrm{~km})$ supports several diverse habitats and biutic sommunities. In general terms. the ecosystems of Kansas and Oktahoma consist chiefty of gecssslands. woodlands. and some shrublands. These ecosysterns are not clearly defined and often overlap or mix. The grakifano ecosystem dominates the land within the boundaries of the CART site. Grassland sypes found within the contines of the CART site include tallgrass. shortgrass. mixed. and sandsage prairie (Jones et al.. 1985). Woodland ecosystems occur most frequently in the eastern regions of both states and along water courses. The Nothern Floodplain Forest type. teaturing cottonwoods and willows. can be found in scattered tracts within the CART site boundartes. Oak-hickory forests nccur in Okmulgee (Oklahoma) and Montgomery (Kansas) Counties. near the CART site's eastern buundary. Shrubland ecosystems are contined to the western reaches of Oklahoma and can bo found in Woodward County.

Many animal spectes thrive within the ecosystems defined by the CART site. Cammom species firtnd in the seven connties containing the proposed sites include badger. heaver. blackmitled juckfatbiti. coyote. deer. fox. house mouse, opossum. quail. and red-eared turtle. 


\subsubsection{Vagalation and Witdite}

\section{5.t.t Gant County, Oklahoma, Contrat Facility}

Originally mixet-grass prairie, most of the land in Grant County is cultivated or dedicated to livestock production. The mixed-gmass prairie ecosystem is characterized by tallorass, sinortgrass, and intermediate-height species, (Jones et al. 1985). Tallgrass varieties occuming in the eounty (USDA, 1985 ) include big bluestem (Andropogon gerardi), switchgess (Panictm virgamm), and indiangrass (Sorghasmum nuants). Blue grama (Bouteloua gracilis), is a shorgrass species that grows in Grant County. Native trees and shubs, though retatively sparse in this counzy, include blackjack aak ( $Q$ uercus murilandica), cotonwood. green ast, and American elm. Eastem red cedar (Juniperus wirginiana), Russian olive. and Austrian pine have been introduced in the county tor use in windbreaks. Windbreaks shield livestock, buildings, gardens, and fruit trecs trom the eflects of high wind and snow.

The Oktatoma Natural Heritage Inventory, a component of the Otwhoma Biolugical Survey, identified 54 antmat species tikely to decur in Gent Cubnty. The badger. beaver. bull snake. eastern cottontail rabbit. Great Plains toad. house mouse. and yellow mud turtle were among the common species identified (Butler. 1991). Common bird species include the mouming dove, barn owl, belted kingtisher, and American crow (Peterson. 1980).

\subsubsection{McClain Counly, Oklahoma, Boundary Facllty}

Oak savannah and mixedegrass prairie tan be found in McClain County. Post oak (Quefcus stellato) and blackjack oak dominate the waodland regions of the savannah (Jones et al.. 1985). Species of vegetation inhabiting the county include big bluestem. blue grama, silver bluestem. and indiangrass.

Witclite species oceuring in the county include heaver, bobcat. coyote, fox squirrel. taccoon. red-tailed hawk. redwing blackbird. and two types (timber and westem diamondbaek) of rattlesnake. Over 75 species of vertebrates occur in the county (Butler. 1991).

\section{5.t.3 Okmutgas County. Okfahoma. Boundary Faciltty}

The Oak-Hickory Woodlands ecosystem, which includes prairie grasslands, is prevalent in Okmulgee County. The hadwod forests in such an ecosystem are dominated by ank-hickory (Quercus-Carya) species (Jones et al.. 1985). Beimuda grass (Cynodon dactolon). Korean lespedeza (Lespedeact stipulacal), bruomisedge bluestem (Andropogon virginicus), and sudan grass are among the vegetation types found in the county (ISDA. 1968).

The bull snake, collared lizard, deer mouse. gray squirrel, mink, plains pocket gopher. pratrite king snake. fed fox, and opossum represent some of the animal species occurring in 
Okmulges County (Butler, 199l). Bird species found in the county include the brown-headed cowbird, northern mockingbird, European starling, and house sparrow (Peterson, 1980).

\subsubsection{Woodnard County, Oklaheme, Boundary Faeility}

Woodward County is located in an area of vast mixed-gtass protie, broken up oceasionally by sandsage prairie. Nattve grasses in the mixed-grass prairie consist primarily of bluestem spectes. Sand sagebrush (Artimisia filfolit) is the dominant grass species in the sandsage prairie (Jones et al. 1985). Native trees that can be found atong streams and in some upland areas include blackiack oak. cottonwoed, elm. hackberry, and willow (USDA, 1963). Eastern red cedar, ponderosa pine, sycamber, and Siberian elm have been used in windbreaks.

The least shrew, northern grasshopper muses, and spotted ground squirtel are most hkely to oceur in the regions of $W$ oodward County that support a sandsage praite ecosystem. Other species crecurring in the county include the big brown bat. bebcat. common snupping turte.

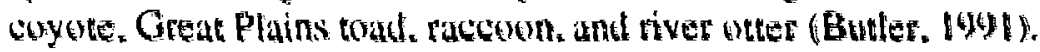

\subsubsection{Kiowa County, Kansas, Boundary Facility}

Vegetation species uccurting in Kiowa County ate typical of the mixed-grass econsystem that is prevatent in western Kansas. Broemweed. goldenrod. indiangrass, switchgrass. wheatgrass, and several varieties of bluestern grass are native to the county (USDA. 1986). American alm. black walnut. black willow. cottonwood. green ash. and Russian mulberry grow in scattered. relatively narrow tracts, usually along rivers and sireams. For windbreaks, eastern red cedar and Siberian elin are the most commonly used spectes. Buckbrush. dogwood. pium. and prairie rose are examples of the county's native shnubs.

Various kinds of wildlife are attracted to the mixed-gross vegetation commonly found in Kiowa County. Larger mammals occurring in the rangeland habitat include, coyotes, mule deer. and pronghom (Jones et al.. 1985). Bobwhite quail, meadowlark, mouming dove, pheasant. and tield sparrow represent some of the bird species found in the county.

\subsubsection{Marion County. Kansas, Boundary Facility}

Noncrop vegetation in Marion County conststs chiefly of tallgrass prairie species. Big bluestent. little bluestem. indiangrass, and switchgrass cat be found in areas where managed grazing but no overgrazing has occurred. Buffalograss. blue grama. and sidenats grama are comtmon in overgrazed areas (USDA. 1983). Native wonded areas of the county occur along upland drainages and along rivers and streams. Common species include American elm. black walnut. black willow. box elder, honey locust. Kentucky offee tree. and silver maple. Windbreaks usually consist of eastern red cedar and Siberiun elrin. 
The rallgruss habitat found in Marion Coungy suppors a variety of animal life, including the bobwhite quail, cottontail rabbit, field sparrow, meadowlark, and pheasant. White-tailed deer. wild turkey, opossum. owl, eaccoon, and squirrel frequent the county's woodlands. The badger. jackrabbit killdeer, and prainie chicken are attracted to Marion County's rangeland (USDA, 1983).

\subsubsection{Montgomary County, Kansas, Boundary Facility}

Montgomery County, lacuted in a region refered to as Cross Timbers, contains both wak savannah and tallgruss prairie ecosystems (16mes et all. 1985). Approximately $40 \%$ at the connty consists of various types of cropland (USDA, 168k), Big biuestem. goldenrod, indiangrass. ragwêd, switchgrass, and wheatgrass are but a tew of the native vegetutum species weturing in the county. Woudtand areas ocepy appeoxintately $10 \%$ at the land in the county. Species mative to upland regions include ash, hackberty, bluckjukk wak, and pest wak. Black walnut. hickory. red oak, pin oak, white uak, pecan, sycamere, and maple are common aleng rivers and streambeds.

Wildtife oestring in the wooded habitats of Montgomery County include white tuiled deer. trpessum. squirrels, owls. hawks. and wordpeckers. Kildeer. jackrobbits, hawks. and dickcissets can be found in the county's rangeland habiat (USDA. 1980). Contontail rabbit. meadowlark, fietd spartow, and red tox frequent the talkgrass prairie.

\subsubsection{Threatened and Endangered Spacies}

Consultation with the Kansas and Oklaftuma viftices of the U.S. Fish and Wildtite Service (FWS) revealed that several federally listed threatened and endangered species have been seen or may uccur in the seven counties under consideration for the ARM Program's central and boundary factitites (see Table 2.2). In Oklahoma. the piping plover (Choratrius melodus) and least tem (Sterna antiltorum) are seasonal migrants asscoiated with unvegetated wetionds and streams (Gill. $199(a)$. Their habitat exists in all four of the Oklahoma counties containing proposed and alternative sites. The bald eagle (Haliue etus letecocphalus) can oecur in river and lake habitats (usually in winter) that exist in the Oklahoma countes examined in this assessment. While the peregrine falcon (Falco peregrinus) is an uncommon migrant to Oklahoma. its habitat (water bodies. wetlands, cropland, and grasslands) oceturs in eath of the four counties. The prairie mule cricket (Gryltotatipa majiar), currently under consideration for threatened status, has been seen in McClain and Okmulgee Counties (Forsythe. 1991b). No federally listed plants ncetir in the Oktahoma counties containing the propesed centrul or boundury sites.

The three counties in Kansas (Kiowa. Marion. Montgomery) that contain proposed and alternative boundary facitity sites provide potential habitats for eight federally listed threatened or endangered animal species. Six of these species (bald eagle. whooping crane, peregrine falcon. teast tern. piping plover. prairie mole cricket) are among those that potentially occur in the four Okjahoma counties identified. The black-footed ferret (Mustela nigripes) is associated with prairie dog towns that can occur in Kiowa County. However, the Kansas office of FWS indicated that no sightings of the black-footed ferret have ever been reported in the county (FWS. 1992). The 
Table 2.2 Federally Listed Threatened and Endangerad Species Occurting or Potentially Occukring in the Counties Containing Centrat or Boundary Facility Sites

\begin{tabular}{|c|c|c|c|}
\hline State & Scjentific Name & Common Name & Status \\
\hline \multirow[t]{6}{*}{ Oklahoma } & Falco paregrinus & Feregrine falcon & Endangerent \\
\hline & $\begin{array}{l}\text { Haliagslus } \\
\text { lougocophalus }\end{array}$ & Baid eagle & Findangered \\
\hline & Grus americana & Whooping crame & Endangered \\
\hline & Sterna antillarum & Least tgen & Endangared \\
\hline & Charadrius melodus & Piping plover & Threatened \\
\hline & Gryllotalpa major & Praine molo aricke & Threatenod \\
\hline \multirow[t]{8}{*}{ Kansas' } & Falco peregrinus & Porogrine talcon & Endangarad \\
\hline & $\begin{array}{l}\text { Haliagelus } \\
\text { leucocephalus }\end{array}$ & Bald eagle & Endangered \\
\hline & Grus americana & Whooping crano & Endangarod \\
\hline & Sterna antillarum & Loast tean & Findangorod \\
\hline & Mustela nigripes & Black-looted tertet & Endangoted \\
\hline & Charadrius melodus & Piping plover & Thteatenod \\
\hline & Noturus placidus & Noosho madrom & Throatonod \\
\hline & Gryllotalpa major & Pratrio molo gricket & Throatoned \\
\hline
\end{tabular}

a Source: U.S. Fish and Witdlite Sorvico Oklahoma Oltico.

bourco: U.S. Fish and Wildtite Sorvice Kansas State Oltice.

Neosho madtom (Nortrus placidtes). a small cattish favoring shallow gravel buttoms. can be found in the Cotconwood River. which flows through a portion of Marion County (Gill. 1991a). No federally listed plant species were reported in Kirwa. Marion, or Montgomery Counties.

No official surveys for federally listed threatened and endangered plant or animal species have been conducted in any of the quarter sections that would contain the sentral or a boundary factility. A listing of FWS Candidate 1 and 2 species that can occur in the seven counties containing the proposed site and its alternatives appears in Appendix F. Candidate 1 species have 
the potential for an official federal listing by FWS; Candidate 2 species are those for which the FWS is collecting data in order to determine their biological status.

\subsection{Land Use}

Land use in the seven counties containing the proposed action and its alternatives is dominated by agriculture, particularly cropland, pasturage, and rangeland. Farmland accounts for aver $90 \%$ of the land in Grant (Oklahoma) and Marion (Kansas) Countes. Urban land uses ascount for less than $5 \%$ of the tand in each of the seven counties. None of the proposed and ultentive facility sites is govemed by zoning regulations or other land use controls. Most of the counties containing the proposed and afternative facility sites have yet to develop comprehensive plans of luture land use maps. Onty the Gront County and MoClain County (Okluhomus) sites are focated within ten miles of a major transportation anery (Interstate 35). None of the proposed and altemative facility sites are located in or near areus of existing or propesed residential development. Existing land use maps of the area immediately surrounding each proposed boundary facility (and the alternatives) appear in Appendix G. Table 2.3 summarizes the proportion of agrieultural lanu and woodtand in each of the counties containing a proposed ot atternative facility.

\subsubsection{Grant County. Oklahoma, Central Facility}

The proposed and alternative sites for the project's central facility are located in the extreme southeastern corner of Grant County. Oklahoma, in the northem part of the state, approximately seven miles southeast of the small town of Lamont (pop. 454). Billings (pop. 555). in neighboring Gurtield County, is located tive miles to the southeast. The Salt Fork of the Arkansas River winds in an east-west orientation approximately three miles to the nurth of the proposed and

Table 2.3 Agriculture in Counties Containing Proposed and Altsmative Facility Sites in 1987

\begin{tabular}{|c|c|c|c|}
\hline County (State) & $\begin{array}{l}\text { Land Atoa } \\
\text { (acros) }\end{array}$ & $\begin{array}{l}\text { Land in } \\
\text { Faims }(\%)\end{array}$ & $\begin{array}{l}\text { Land in } \\
\text { Woodland }(\%)\end{array}$ \\
\hline Grant (Okląhomą) $)^{3}$ & 642.739 & 90.7 & 0.5 \\
\hline MeClain (Oklahoma) & 372,179 & 72.9 & 2.5 \\
\hline Okfatges (Oklahoma) & 446.425 & 55.9 & 6.0 \\
\hline Woodward (Oklahoma) & 794.948 & 86.1 & 0.6 \\
\hline Kiowa (Kansas) & 462,572 & 84.8 & 0.01 \\
\hline Marion (Kancasib & 604.243 & 95.6 & 2.5 \\
\hline Montgomery (Kansas)b & 413,292 & 79.2 & 10.0 \\
\hline
\end{tabular}

a Soutcè: USEC, $1987 \mathrm{a}$.

Source: USEC, $1987 b$. 
altemative sites. The sites can be reached by county section roads, most of which are unpaved. Major transportation arteries in the area include U.S. Highway 60, running east-west six miles north of the proposed facility site, and Interstate 35, a north-south route located approximately eight miles east.

Agriculture is the dominant land use itr Grant County. Over $90 \%$ of the land is dedicated to farming. Agricultural uses include cropland and rangeland for pasturage. Wheat accounted for most of the cultivated crop in recent years. USDA-designated prime farmland accounts for $71 \%$ (457.000 aeres) of the soils found in the county (USDA. 1985). The county has not yet developed a comprehensive plan, and no zoning controls exist in the immediate vicinity of the proposed site and ist alternatives (Shafter. 199l).

Land use in the immediate victinty of the proporsed and altenative sites for the central facitity is almost exclusively agricultural (see Fig. 2.1). consisting of coplund, pasture. and eangeland. Over $75 \%$ of the soils in the quater sections containing the proposed and aftemative sites are considered prime. Small woodlund tracts can be found a few miles north of the proposed facility site. along the Salt Fork of the Arkansas River.

\subsubsection{McClain Courty, Oklahoma, Boundary Facllty}

The proposed and altemative sites for the McClain County boundary fatility are located in the south central portion of the county, amid rolling and hilly topography. approximately 35 miles south of Oktahoma City and 8 mites southwest of Purcell. Interstate 35 runs north-south through Purcell. and the Canadian River tlows another mile east of the interstate. The sites cin be actessed by county section roads that are sypically unpaved.

Agriculture is the major land use in McClain County. Almost $73 \%$ of the land is in farmland (USDA. 1979). Abandoned cropland used for grazing and rangeland account for most of the remaining tand in the county. Crops produced within the county include wheat. sorghum. cotton. soybeans. and peanuts (USBC. 1987a). No zoning controls exist for the portion of the county containing the proposed and alternative sites.

Land use in the immediate vicinity of the proposed and alternative sites comprises pasture and sangeland. scattered tracts of woods, and an oceasional cultivated hield (see Appendix G). Evidence of past activity related to oil extraction operations exists on a parcel of land approximately two miles south and west of the proposed site. and an oil derrick is located on the south side of state Highway 24, two miles southeast of the proposed site. A pipeline that runs northwestsoutheast gasies within a few meters of the southwestern corner of the quarter section containing Alternative 1. Another pipeline. having a north-south orientation, passes within 0.75 miles of the eastern edge of the quarter section containing the proposed site. NOAA profiler equipment is located in the quarter section containing the proposed facility site. 


\subsubsection{Oknulgee Gounty, OkJahoma, Boundary Facility}

The proposed boundary site and its alternatives are located on gently rolling terrain in the northeast comer of Okmulgee Counzy, 6 miles west of Hasteti, Ukiahoma, and approximately 20 miles south of Tulsa. The Arkansas River is located tpproximately 8 miles north of the proposed and altemative sites. It also passes 7 miles to the east. The sites can be reached from county section roads, most of which are unpaved.

Agriculture and woudlands are the prevalent lind uses in the county. Wheat, soybeans, sorghum, alfalfa. smalt grains, and livestock are the primary products (USBC, 1987a). No zoning restrictions apply to the land in or around the proposed site of its altematives.

The land in the immediate vicinity of the proposed site is dominated by wadiand. rangeland, pasture. and some cultivated crops (see Appendix G). A large area of wondtand strethes to the north and west of the proposed and alternative sites. Single-fanily residences are scatered hroughout the area surtounding the peoposed and atternative sites. An clectrical power transmission line running if a northwest-southesst difection. passes approximarely 1.5 mi 70 th af the proposet site. A pipeline with a northwest-8outheast orienation runs uppoximately two miles south of the proposed site. NOAA profiter equipment is licuted in the quarter section immediately east of the proposed site.

\subsubsection{Woodward County, Oklahoma, Boundary Facilly}

The proposed and atternative sites tor the Woodward Counly boundary tacility are located in an area of rolling rangelund on the southem edge of the county, two miles nortiwest of the town of Vici, in the northwestern part of Oklahoma. The Dewey County line is 0.25 miles south of the proposed site. The Canadian River flows approximately ten miles south. The proposed and alternative sites can be accessed from U.S. Highway 60. 1.5 miles south, wr state Highway 34. 1.5 miles east.

Agriculture dominates land use in the county. with $86 \%$ of the county's land area dedicated to tarming. The county's principal agricultural products include wheat, sorghum, alfalio and small grains, sheep, poultry, and cattle (USBC. 1987a). Recreational opportunities in the county can be found in Botling Springs State Park. Iocated approximataly 20 miles north of the proposed facility. No zoning restrictions exist for the portion of the county containing the proposed and alternative sites.

Rangeland and pasture are the dominant land uses in the immediate vicinity of the proposed and alternative sites (see Appeñudix G). Som̃e scattered wooded tracts lie within a mile of the proposed site. and larger areas at woodland are within 1-3 miles southwest and northeast of the proposed site. Some prime soll is in the quarter section containing Alternative 2. A pipeline running east-west is located approximately 2.5 miles south of the quarter sections containing the proposed and alternative sites. 


$$
E^{4}
$$




\subsubsection{Kiowa County, Kansas, Baundary Facility}

Lutated in south central Kansas, the proposed and alternative boundary tacility sites sit on relatively tat terain in the nurtheast curner of Kiowa County. Kansas. The gown of Havilund is located two miles south of the proposed facility site. U.S. Highway 54 runs through Havilund in it westerly direction toward the town of Greensburg, upproximately ten miles to the west of the proposed and alternative sites. The Rock Island and Pateific Railitoud line runs just north of and paraltel to U.S. Highway 54. The Pratt Sandhills State Wildlite Area is in Pratt Counly. directly auross Kiowa County's eastern burder. The propused and atternutive sites can be reathed trom sounty section roads.

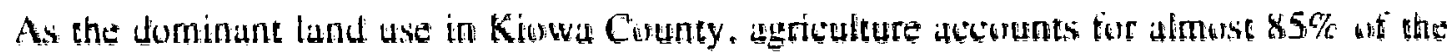
land (USBC. 1987b). Agricultural uses include cropland and rangeland tur pasturisge. Wheth. surghum, com, suybeans, and altalla are the thiet erops profuced, and beet eatle. hugs. and pigs

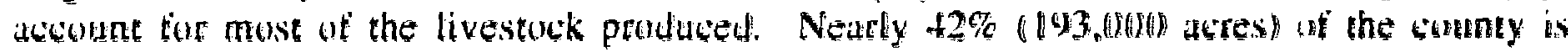
considered prime fartaland (USDA. 1686). The Kiowa Cutnty State Park is lorcinted immediately northwest of Greensburg. The county has nor yet develuped a comprehensive plun. und atun zonings controls exist in the partels conuining the proposed tiaclity und its afternatives.

Center-pivot-irrigated cropland, gasture, fangetand, stattered tree lints. Consertatibnt Reserve Program (CRP) native grass. and urban areus (Havilund) muke up the land use in the immediate vicinity of the propesed and altemative sites (see Appendix G). No prime sail is in the parcels contuining the proposed and attemative sites. A pipeline running trom the suruthwest to the nurtheast passes under the quarter section combining the proposed site und under the onorthwes!

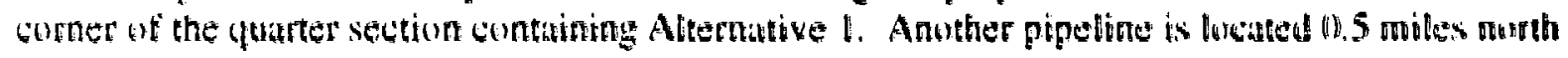
of the greposed and Alternative $I$ site.

\subsubsection{Mation County, Kansas, Boundary Facility}

The proposed boundary lacility is comptised of two parcels of land in sumthwestem Marion Cuunty. Kansas, in an area of gently to moderately sloping bongraphy. The larger parcel $60(0)$ acres) is located four miles south of the cown of Lehigh (see Appendix $\mathbf{G}$ ). The smailer parcel ( 1.75 acres), which would contain the RASS. is lecated approsimately wo miles south of Lehigh. The city of Hillsboro is four miles to the east of the proposed site. An Alchisun. Tupeki. and Sarta Fe tail line enters Lehigh from the west. passes within 0.5 miles of Alternative 2. and continues east inte Hillsbure and Marton. The Suth Coutonwowd River flows approximately one mile north of the propensed site. The proposed and alternative sites wan be reached from U.S. Highwary 56. which roms cast-west M.S miles suth of Lehigh, and from state Highway 15. a nurttesucth poute that passes two miles to the west of the propened and afternative sites.

Over $95 \%$ of Marion County's land is dedicated to agricultural tand uses (USBC. 1987b). Approximately $60 \%(680)$ of the 1.119 farms in Marion County produced beef and dairy cattle in 1987. Crops produced in the county included wheat, sorghum, com, soybeans, uats. and alfalfa. Over 75\% (465.000) acres) of Marion County soils are considered prime (USDA, 1983). Recreational tand uses in the county include Marrion Lake and the Marion Lake State Wildlife Arear. 
located approximately ten miles northeast of the proposed site. The county recently adopted i resolution to form if planning and zoning commission and besin the process of develkping a comprehensive plan in the spring of 1992 . Presently, no existing zoning regulations affect the proposed and alternative sites.

Land use in the immediate vicinity of the proposed und alternative fucility sitex consists of pasture, rangeland, scattered trees, and urban areas (Lehigh and Hillsboro). Almost all of the land reserved for the proposed and altemative sites is ctrnsidered prime. NOAA protiter equipment is torated in the southem end of the quarter section containing the patipused site.

\subsubsection{Montgomery County, Kansas, Boundary Facility}

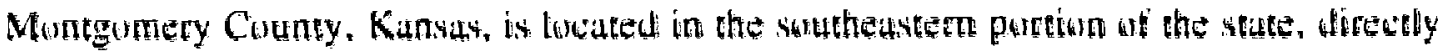

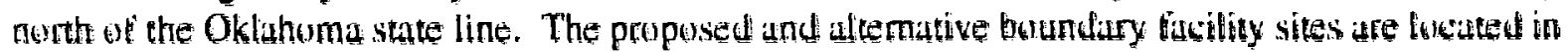

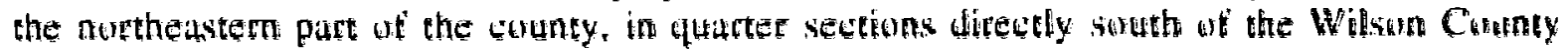

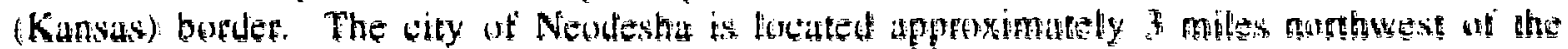

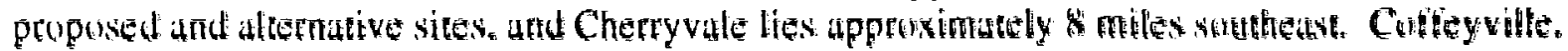
the councy's largest city. is located 23 miles south of the pouposed and aflemative sites. The Verdigris River flows 1.5 miles west of the proposed site. The St. Louts-Sin Frantisen rain line. which runs in a southeasterly direction from Neodeshu to Cherryvale. passes within 1.5 miles of the proposed and alternative sites. The Missouri-Pacific rabl tine passess approximutely 2 miles to the west of the proposed site and heads north into Netdeshat. The proposed and altemative sites can be aceessed by state Highway 26.3 miles to the west of the sites, and trom state Highway 37. which runs cast trom Neodesha beture it turns sotth and passes within 2 miles of the proposed site.

Agriculture dominates land use in Montgomery Cornny. Almost sure of the evounty is comprised of farms (USBC. 1987b). Principal crups inelude allalio. sorghum. soybeans. and wheat. Over 700 of the county"s 974 farms sold cuttle and calves in 1987. Recreational hand uses in the cotnty include Elk City Lake. Elk City Sule Purk. and the Elk City Stute Wildlite Area. a contiguens network of recreational areas lecated approximately lob miles souhwest of the proposed and alternative sites. Big Hitl State Willlite Area and Bigs Hill Lake are located approximately 12 mites southeast of the proposed site. The sounty has ne somprehensive plas or zoning broly. No fand use centrols apply to the area surtunding the proposed site and its alernatives.

Lund use in the immedtate vicinity af the propossed and altemative sites (see Appendix G) contsists of cropland, pasture, tangeland, scattered trats of wouds, ant an urban area (Nendeshal. Approximately $20 \%$ of the land reserved for the propesed fuctlity is considered prime (SCS. 1909). NOAA profflet equipment is fucated un the western edge of the quarter sectim contuining the proporsed tincility site. 


\section{Visual Resources}

An inventory of the visual resources of an area is necessury to deremine the inherent qualities of the lundisige and to establish levels of intrusion that a given attion or project may introduce to sensitive receptor areas. Examples of sensitive receptor areas include residentiant developments, major roads, schools, parks, nutweil areas and wails, unique landforms (blutis, overhangs, leuges, eto, ), and shorelines. Cumponents of a landscupe include vegetatim. lamdtom, water, and man-rnade structures (USDA, 1985). Lindscapes can be categorized thigh,

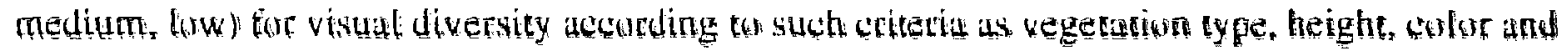
distriburion pattern; water clarity and shreline detinition: londform gype and height: and the

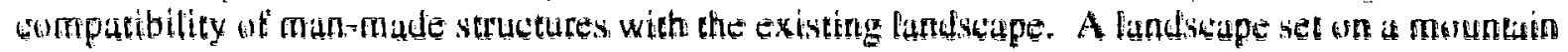

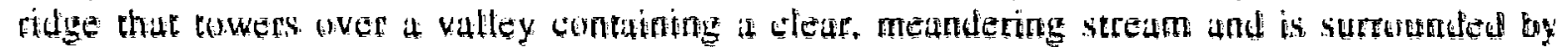

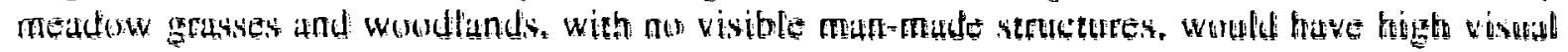
diversity.

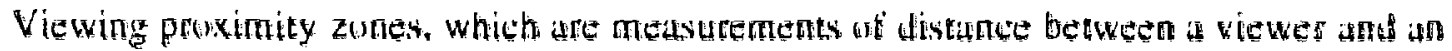

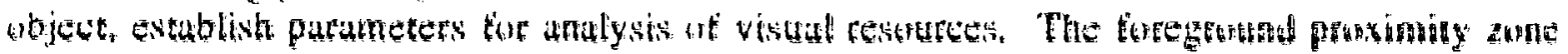

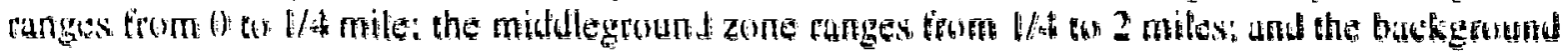
zone consists of views trom between 2 and 5 miles (and beyond).

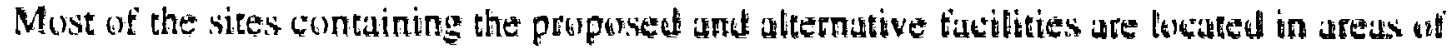
telatively low to medium visual diversity.

\subsubsection{Grant County, Oklahoma, Conieal Faellity}

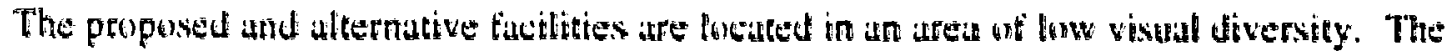

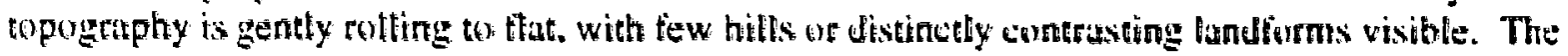
vegetation pattem is charactertstic of the cropland and rangeland that dominates the county. There is some diversity in heighe but litule in colur. Trees and shrubs are scatered atross the hurizun. and no water features are visible in the any uf the viewing proximity annes surrounding the peoposed site. The primary sensitive viewers constst of residents in humes and farmsteads seattered throughout if five-mite ratiss afound the proposed site. The nearest fown fBillings is tove miles away. No unique views or vistas are apparent in the vicinify of ho propused bicility. Photographs or the proposed action that were taken from within the toreground and middleground vewing prowinty zenes appear in Appendix $\mathrm{H}$.

\subsubsection{Mectain County. Ottahoma. Boundary Fácility}

The McClain County proposed and altermative sites are set in an area of medium visual diversity. The lical topugraphy is dominated by low, rended hills and several drainages (Finn. Wildcat. and Wolt creeks) of the Washita River. Some of these drainages are ateep. in contrast to the sutrounding robling landtorms. Some uncommon viewpoints and vistas are lowated on the highest porints of the hills near the propessed and alternative sites. Several man-made structures (cementrnication. Water. and hit industry towers) are visible from viewpoints surrounding the 
proposed site. Traveles on state Highway 24 und residents of tho homes and farmsteuds statered in ative-mile radius around the proposed site would be the primary sensitive viewers.

Appendix $H$ contains foreground and middleground views of the propused tatility. The

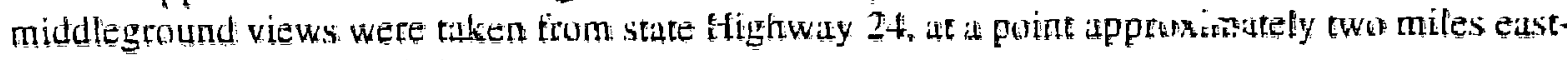
mortheast of the proposed site.

\subsubsection{Okmulgeo Cownt, Qhahoma, Boundary Facility}

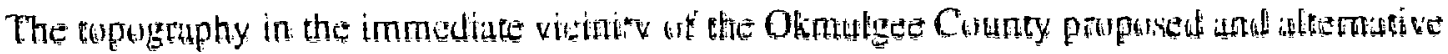

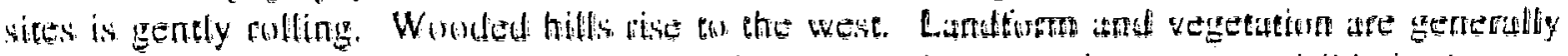

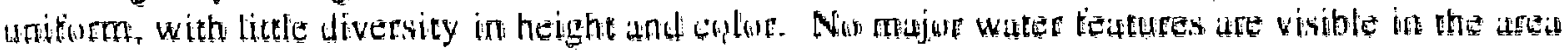

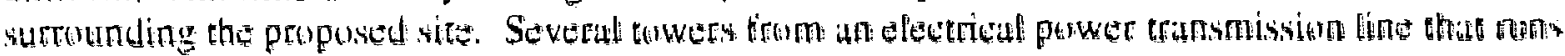

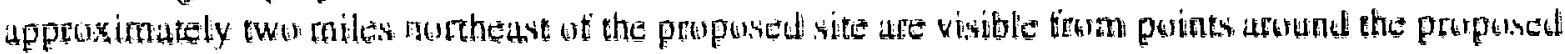

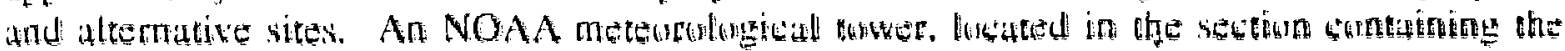

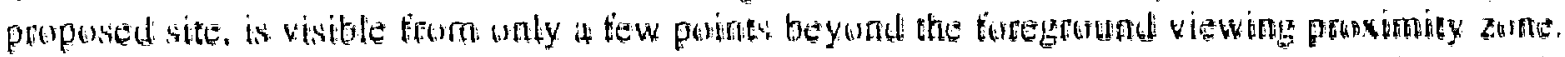

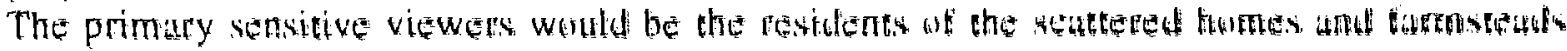
surtounding the proposed and altermative sites.

\subsubsection{Woodward County. Oklahoma, Boundary Facility}

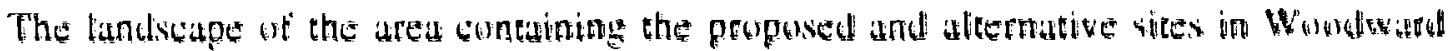

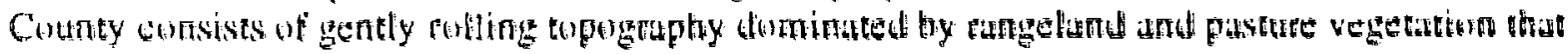

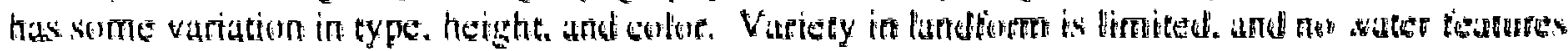

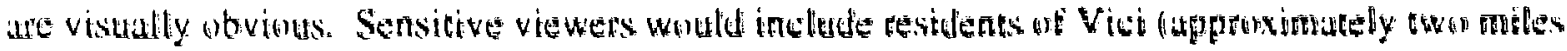

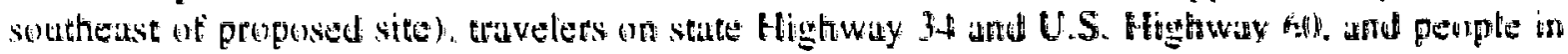

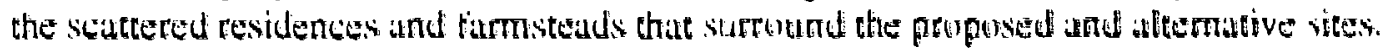

\subsubsection{Kiowa County. Kansas, Jnundary Facility}

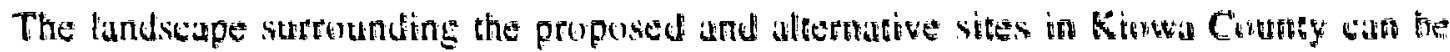

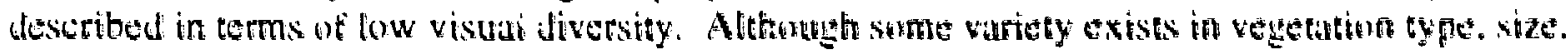

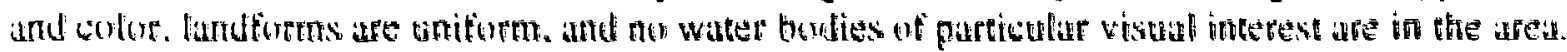
A meterological thwer ogersted by the NOAA is hewted within 1.5 mites af the purpused site. and

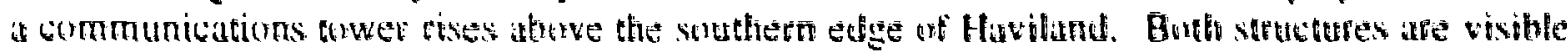

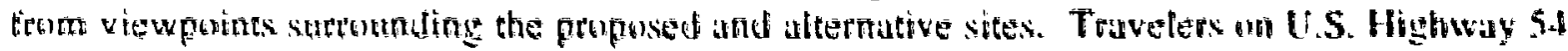

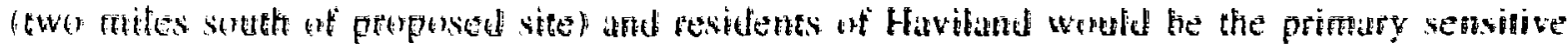
viewers. 


\subsubsection{Marion Gounf, Kansas, Boundary Facility}

The landsupe containing the proposed and altermative sites in Marion County is diministed by colling fopography of limited variation and an agricultumal vegetulive cover of medim diversity in type, height, and eolor. Tree lines and isolated trees can be founc in candomly seateret pattems throughout the area surronding the proposed site. Steep inclines associated with Stony Brovk (immediately south of the proposed site) and the South Cotonwool Rivar (approximately une mile

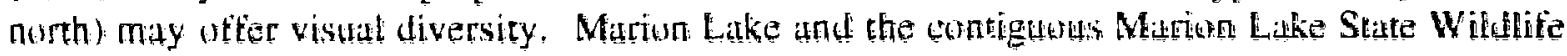

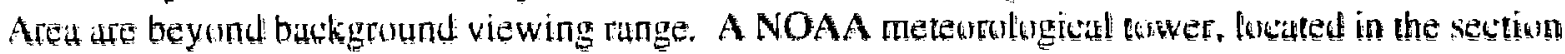

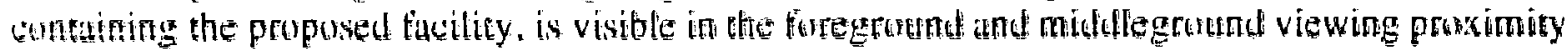
zone. The primary sensitive viewers whutu inelude maveless atmon U.S. Highway 56 innul residentits of Letrigh and Hillsburo.

\subsubsection{Montgomery County. Kansag, Boundary Facility}

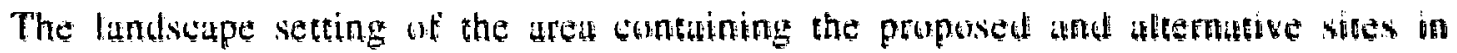

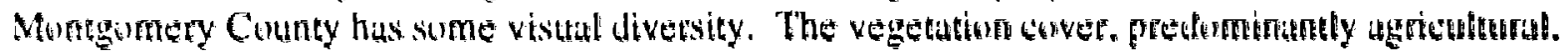

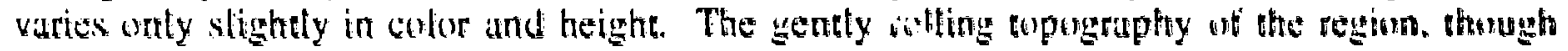
mostly unitorm. is interrupted by the steep drainages of the nearby (1.5 miles west) Verdigris River. The areas with the highest potential for viewing diversity. Elk City State Park. Elk City Sture Wildlite Ared, and Big Hill Lake. are located beyond the proposed site's baskground viewing

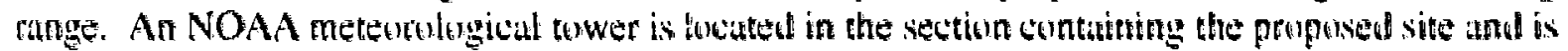
visible within the foreground and middleground viewing proximaty zones. Primary sensivive

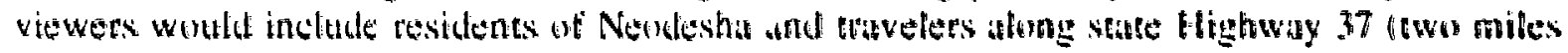
salist).

\subsection{Cultural Resources}

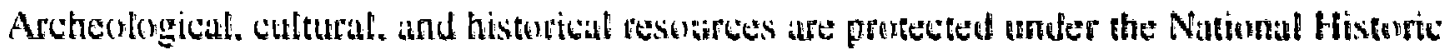

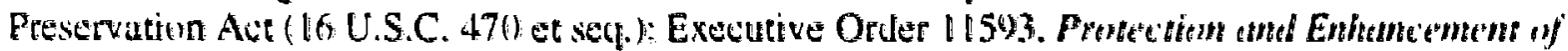

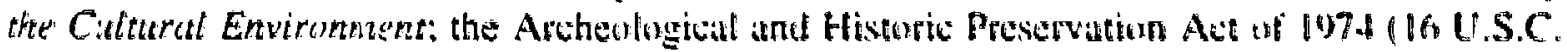

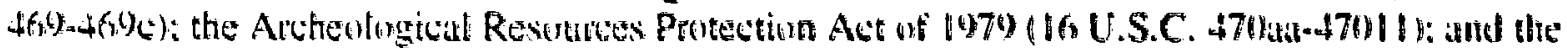

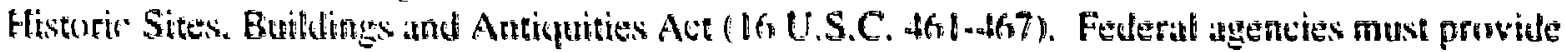
an opportunity for comment and consultation with the appopriate state historic preservation onftiter

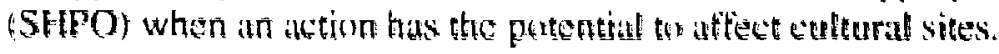

The Oklahema and Kansas State Historic Preservation Omices have detemined that mo archerlugtcal sites ar historic strtctures listed on the National Register of Historic Places or the fespective state inventortes exist in the areas that would be affected by the proposed site or its attematives (Pankrante. 1991: Gettys and Brouks. 1991). A list of . itructures and sites appearing 6ro the Nationat Register ent Histuric Places that are located in the counties comtaining the proposed bentrall and butndiry sites is presented Appendix 1. 


\subsubsection{Grant County, Oklahoma, Contral Facility}

The Oklahoma SHPO detemined thit no archeotogical surveys woutd be necesistry for the central facility sites and that no archeological sites or historic structures listed on the National Register of Historic Places or state inventories exist in the quarter sectivets in Grant County containing the proposed sire ur its altemative sites (see Appendix D).

\subsubsection{Meclain County. Oklahoma, Boundary Facility}

The SHPO reported a potential tur prehistoric archeologicat resoures at the McClain County brundary tacilicy site and subsequently conducted an archeological survey of the stet int its altertatives. The state archeologist reported no prehistoric raterials and conclublet that no

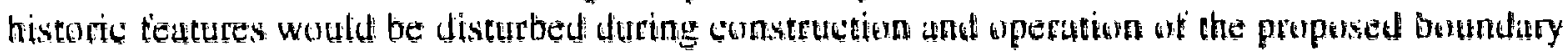
tacility. No urcheological sies or historic stouchures listed an the Nitional Register at Histomit Places or state inventories are licated in the parcels of land cuntaining the proposed site or its alternutive sites.

\subsubsection{Okmulgeo County, Oklahoma, Boundary Facility}

The SHPO determined that no archeological surveys would be necessary for the proposed boundary facility or its altematives in Okmugee County and that no archenlogital sites or historic structures tisted on the National Register of Histeric: Places or state inventories exist an the guarter sections conturing the proposed site or the alternative sites.

\subsubsection{Woodward County. Oklahoma, Boundary Facility}

Oklahomi's SKtPO determined that no archeologital surveys would be necessary for the proposed boundary tactity or its altematve sites in Wordward Couny. No archeological sites ur tristoric structures listed on the National Register at Historis: Plates or stale inventories exist in the quarter sections containing the proporsed site of the altemative sites.

\subsubsection{Kiowa County. Kañsas, Boundary Facillty}

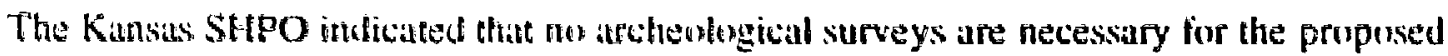

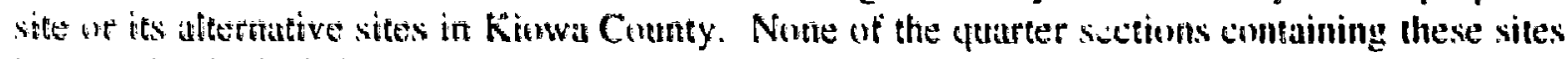
have artheological sites or historic structures listed on the National Register of Historic Places or state inventories. 


\subsubsection{Mation County, Kansas, Boundary Facility}

The Kansas SHPO reported that the Lower elevations along Stony Brook in the Marion County proposed boundary facility site have the potential for archeobogicul resources. Nos archeulogical sites or structures appearing on the National Register of Historic Places or state inventories were tound in purcels containing the proposed site or tts altemative sites.

\subsubsection{Monigomery County. Kansas, Boundary Facility}

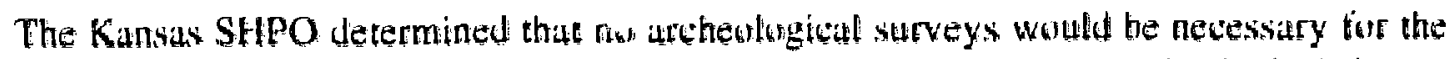

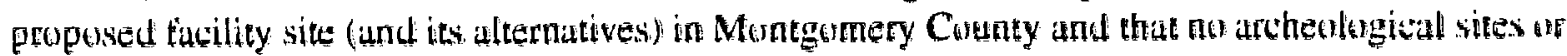

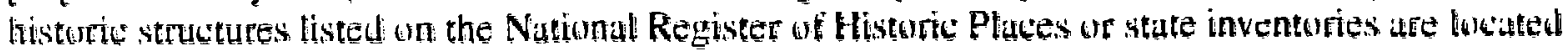
in the glarter sections containing the proposed site he its altemivive sites.

\subsection{Socioeconomics}

The seven counties examined in this andysis are predominanty rutal. Except tar the proposed and alternative boundary bucitity sices in Mungomery Cutrnty (Kunsas). none of the sites are located within ten mites of a town or city exceeding S.Mfin people. Population in the seven counties for 1990 (see Table 2.4) ranged trom 4,046 in Kiowa County (Kansas) 10 \$2.281 in Muntgomery County (Kansas). Ail af the counties except MeClain County (Oklahoma) experiencel population declines between 1980 and 1906 . The most current $($ August 1901$)$ labur

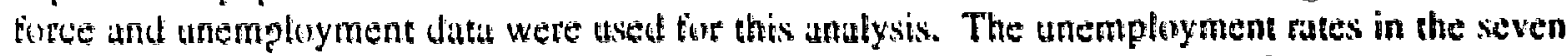

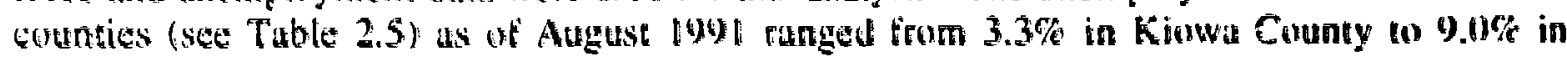
Okmulgee Councy (Oklahorma). All of the countes tmoler exarnination for this study have exhibited trends of increasing unemployment over 1990 thetals.

Table 2.4 Population and Growth Rates in Countes Containing Proposed and Alternative Facility Sitos. $1980-1990$

\begin{tabular}{|c|c|c|c|}
\hline Counly (Stato) & 1950 Fopulatoma & 1990 Fopulatian & $\begin{array}{c}\text { Chango } \\
1980-1990 \quad\left(v_{i}\right)\end{array}$ \\
\hline Grant (Ok!3ngma) & 6.519 & 599 & .12 .7 \\
\hline MeClan (Okinhoma) & J.29 & 22.795 & 12.3 \\
\hline Qhnulgee (OAlahoma) & 39,169 & $36 . \$ 50$ & .6 .8 \\
\hline Woodward (Oklatoma) & $2 \hbar, 172$ & 18.976 & -10.3 \\
\hline Kiowa (Kansas) & $4,0.46$ & 3.660 & .9 .5 \\
\hline Marion (Kansas) & 13.522 & 12.888 & .4 .6 \\
\hline Montgomery (Kansas) & $42.28 t$ & $38.8 \pitchfork 6$ & .8 .1 \\
\hline
\end{tabular}

\footnotetext{
- Source: USBC, 1988.

Source: USBC, 1990a; USĒC, 1990b.
} 
Table 2.5 Labor Force and Unemployment in Counties Containing Proposed and Alternative Facility Sites, August 1991 (BLS, $1991)^{2}$

\begin{tabular}{|c|c|c|c|}
\hline \multirow[b]{2}{*}{ County (State) } & \multirow[b]{2}{*}{ Labor Foree } & \multicolumn{2}{|c|}{ Unemployment Rate $(\%)$} \\
\hline & & 1990 & August 1991 \\
\hline Grant (Oklahorna) & 2,996 & 3,3 & 4.1 \\
\hline Meclain (Oklahoma) & 11,010 & 5. 3 & 5.7 \\
\hline Okmulgee (Oklahoma) & 14,369 & 8.2 2 & 90 \\
\hline Woodward (Oklahoma) & 9,780 & 4. 6 & 6.6 \\
\hline Total Oklahoma & $=$ & 5.5 & 0.2 \\
\hline Kiowa (Kangag) & 1.852 & 2.1 & 3.3 \\
\hline Marion (Kansas) & $6,1: 96$ & 3.2 & 36 \\
\hline Montgemery (Kanoas) & 19.294 & 5.9 & 6.7 \\
\hline Total Kansas & + & 4.4 & 4,6 \\
\hline
\end{tabular}

\subsubsection{Grant County: Oklahoma, Contral Faetlity}

Grant County occupies $1 .(000)$ square miles und had a 1400 population of 5.689) (USBC. 199()$\left._{a}\right)$. With 41990 population density of 5.7 people per square mile. this predominantly rural county experienced a $12.7 \%$ decline in its population between 1980 and 1990 (USBC. 1991a). Medtord. the county seat, is located approximately 20 miles northwest of the proposed facility site and had a 1990 poptlation of 1,172. Cities and towns near the proposed fatility and their lven poputations include Billings ( 5 miles south in Kay County). 555: Lamont 77 miles northwest). 454; and Tonkawa (1/ miles northeast in Kay County). 3.127. The largest city within 501 miles of the proposed iacility site is Enid (population 45.3618), in nearby Gartield County.

In August 1991. a labor tore of 2.996 was repurted in Grant County (BLS. (49)1). The unemployment rate in Granc County for the same periud was $4.1 \%$. The unemployment rate in the state of Oklathma doring August of 1991 was $6.2 \%$.

\subsubsection{MeClain County. Oklahoma, Boundary Facility}

McClain County, which is predominantly rural, experienced a $12.3 \%$ increase in population during the 1986 s. Its 1990 population was 22.795 (USBC. 1991). The county covers an area of 569 square miles and had a population density of 40 people per square mile in 1990). Purcell, the county seat. is located eight miles northeast of the proposed facility site and had 4.760 residents in 1990 . Cities and towns within 15 miles of the proposed fucility site include Purcell: Lindsay (approximately 10 miles southwest in Garvin County), with a 1990 population of 
2,947; Matuville (approximatety 12 miles southeast in Garvin County), with a 1990) population of 1,203 ; and Wayne (approximately 12 miles east-southeast), with a 1990 population of $51 \%$.

In August of 1991. 11,016 people were employed in McClain County, and the unemployment rate was $5.7 \%$ (BLS, 1991).

\subsubsection{Oknutge County, Oklahoma, Boundary Facility}

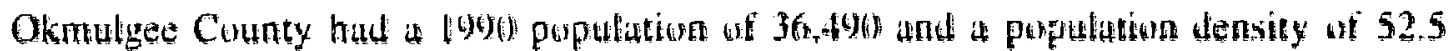

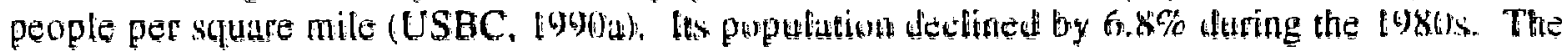
city of Okmulgee. lucated approximately 15 miles susthwest of the proposed facility site, serves as

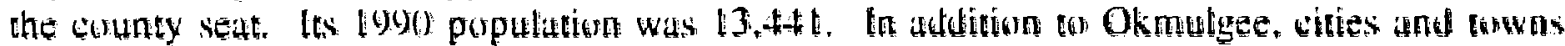
within 15 miles of the proposed facility site and their 1060 (1) perpulations include Haskell (6 miles edst in Muskogee County) 2.143: Bixby (apperoximutely 11 miles atrthwest in Tuks Comuny). 5.501: and Coweta (approximately 12 mites northeast in Wagner County), 6, 159).

The labor torce in Oknulgee Cotenty was 14,369) in Auguse tegy (BLS. 1991). During the same month, the county experienced an unemployment wate of 9 . 1$)^{\circ}$.

\subsubsection{Woodward County, Oklahoma, Boundary Facility}

Woutward County, with a 1900 population of 18.976 (USBC. 1946)a), is the largest (1.242 spuare miles) of the seven countes considered in this study. Its predominuntly rural poputation declined by $10.3 \%$ during the $19891 \mathrm{~s}$. Pupulation density in the county was 15.3 people per square mile in 1990). The city of Woodward, huated approximately 18 miles north of the proposed facility site, serves as the county seat. The city had 12.340 residents in 1990). Vici. with a 1990 population of 751 . is the nearest town ( 2 miles sontheast) to the pruposed facility site. No towns or cities within 15 miles of the propesed site have popufations of more than 500 .

Over 9.700 people were employed in Wondward County in August 1991. when the unemployment rate was $6.6 \%$ (BLS. 190) $)$.

\subsubsection{Kinsa County. Kansas, Boundary Facility}

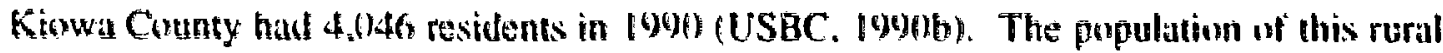

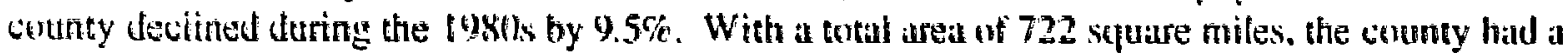
perpulation density of 5.1 people per square mite in 1900 . The county seat is Greensburg. luciated approximately 11 miles southwest of the proposed site. The town had 1.792 peuple in 1901). The city ar town closest to the proposed factity is Haviland (1.5 miles south), with a 1990 population 6f 624. Combinet. these two urban areas make up almost $610 \%$ of the entire population in the ciounty. 
Kiowa County had a tabor force of 1.852 and an unemployment rate of $3.3 \%$ in August $199 \mathrm{~L}$ (BLS, 1991 ). The state of Kansas experienced an unemployment rate of $4.8 \%$ during the same month.

\subsubsection{Mration Gounty, Kansas, Boundary Faeility}

Predominantly rurat, Marion County had a 1990 population of 13,522 (USBC, 1990b). The county eovers 943 square miles and had 13.7 people per square mile in 1990 Located approximately 14 miles east of the propessed site the county seat of Murion had a 1990 population of 1.906 . Cities and towns within ten miles of the proposed site. along with their 190 ) populations, include Lehigh (two miles northwest). 180; Hillsboro (four miles east). 2.7(14: and Canton, in MoPherson County (seven miles nurthwest) 794.

In August of 1991, 6.186 people were empluyed in Marion County, and the unempluyment rate was $3.6 \%$ (BLS. 1991 ).

\subsubsection{Montgomary County, Kansag, Boundary Facillty}

Montgemery County had a 1990 populution of 42.281 (USBC. 19916). Oecupying 645 square miles and mostly rural. the county had a 1990 population density of 60.2 peuple per square mile. The largest city in the county is Corfeyville (approximately 25 miles south of proposed site). with if 1990 population of almost 12.917. Independence, the county seat, is lowated approximately 9 miles southwest of the proposed site and had 9.942 residents in 1990. In addition (10 Independente. cities and towns within 15 miles af the proposed site include Nendesha 2.5 miles northwost in Wilson County), with a 1906 pepulation of 2.834 . and Cherryvale 17 miles southeast), with 2.464 people in (99)).

In Auguse $199 \%$. Montgomery County had a labor toree of 18,284 and an unemployment rate of $6.7 \%$ (BLS. 1991$)$. 


\section{Environmental Impacts of Proposed Action and Alternatives}

This chapter will provide an exaluation of the potential environmental impatts at the proposed and attemate sites of the central fiacility and the six boundary factities resulting from ARM program activities in Okjatema and Kansis. The impacts covering nine key environmental areas will be presented: (1) soils and geology: (2) water resources: (3) air quality: (4) noise; (5) biotic resources; (6) land use; (7) visual resources; (8) culturat resources; and (9) socigeconomics. The distession of environmental impats will be based on current baseline environmental conditions (at the various tacilities) and the resulting impacts of the activites involved in the ARM program. Impacts are evuluated for both the construction phase and the wperation phuse.

\subsection{Solls and Geology}

\section{3.t.t Construction}

Only small ateas would be sleured and geaded (i.e. less than th.3 dures at a time, with a total of about $\$ .8$ and 1.5 acres tor the central and boundary facilities, respectively) and only mimor excavation would be required to install the meteorolugical and radiation measurement equipment and lacilities (mobile homes or portable buildings, storage sheds, and semi-trailers). As a result. there would be no atlects on local geology and mineral resources at any of the sites fcentral facility. boundary facility, auxiliary tacility. and extended sitest. The thed terrain would be modified slightly. since the site selection requirements are focused on nearly level areas as a sciemtific criterion. Non loss of or permanent damage to shil is expected: even the removed copsoil would be stockpiled ur moved to atjacent land to ensure its protection. if requested by the owner. Very minor effects from soil erosion are expected. dfue to the small area that would be disturbed.

As identifted in Appendix B, most of the areas to be disturbed would be coveret with plastic sheeting and gravel, white ather areas would be vleared. and a concrete pad would be placed. The etfects of this type of treatment and even installation of the concrete padding would nut be permanent. and the entire site would be returned to the original fand use at the cinclusion of the ten-year project.

\subsubsection{Oporation}

There wortlat be unly rotinimal predicted impact during the operation phase of the project. Sotl ercsion whuld be minimal due to the smal! surface area and the nature of the facility. The problem with the more clayey soils that tend to have more movement and tend to shrink and fill more during summertime and wintertime than lvamy snil (as mentioned in Chapter 2) would have an impact for large facilities but not for the instruments and small trailers proposed for the ARM Program. 


\subsection{Water Resources}

\section{2.t Surtace Water}

\subsubsection{Construction}

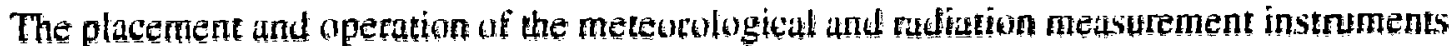
would avoid contact with any creeks or rivers. No impaess are likely to any of the sites, including auxiliary and extended sites, during the comstucton phase of the project. Warer requitements tor sonstrugtion woutd be minor and would be met by water tank trukss for dust controt and buted water and a portable toilet for personnel during comstruction.

\subsubsection{Operation}

No impacts are likely to the surtice wates at any of the sites. inclucling ausiliary and extended sites. during the operation phase of the project. As discussed in Chapter 1 . only the central taciticy would be permanently statted. and would therefore require both potable water and a sepric systam. The site is sutficiently near commercial water mains, and these wauld be used. The potential problems associated the tow permeability of the soils as an absorption field at the central facility (mentioned in Chapter 2). would nut present a problem for the ARM program. in terms at surtace water, since the proposed septic tunk is small (designed tor up to 6 people). The septi: tield would be installed in compliance with hoal regulations. In the event that aflitional burden is placed on the septic system trom visiting scientists of other personnel on a temporary basis. sanitary capacily at the central tucility would be stupplemented with portable twilets of the type ased at the boundary facilities.

\subsubsection{Groundwater}

\subsection{2.t Construction}

The placement of the meteorological and rudiation measuring equipment and facilities tnvolves only minor excavation and would. at most. lest to penetration of the ground by unly 5.6 tit. This level of minor excavation is unfikely to affect potnble groundwater since depth to srountwater in this area ts typically greater than $50 \mathrm{ft}$.

\subsubsection{Operation}

As discussed in Chapter 1. the proposed action for the ARM program calls for a small septic unk at the central facility. The problems associated the soils low permeability as an absotption tield at the central tacility (mentioned in Chapter 2). would not present a problem for the 
ARM program, in terms of groundwater, since the proposed septic tank is small (designed for up to 6 people). The septic tield would be instalted in compliance with locat regulations. There will be no chemical wastes produced, and therefore no potential for impact to the groundwater.

\subsubsection{Wetlands}

\subsubsection{Construction}

As indieated in Chapter 2. wethnds afe present at all of the alternative sites in McClain Cutnty and at altemative sites 1 and 2 in Okmulgee. The presence of wetlands at Marionand Mungumery Counties, does nut appear likely since these areas hase not been mupped for wedlinuls and mapping usually takes place tor areas that are likely wethads candidutes. For those sites for which wetlands have been identified, no, construction or contut with any wetland area is needed or worklut be made as part of this ARM experimentat eftor. Sinte the disturbed area required for a

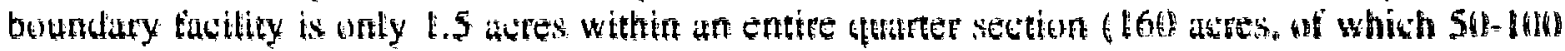
acres bound the needet area), ample rorm is availuble away from the wethond area tor equipmem placement.

Auxiliary and extended sites have significuntly less equipment and facilities, but they still have the same environmental requirements tor siting. One of the criteria for chussing the abxiliary and extended facility sites ts the avoidance of wetlands. Consequently. by that criterion. nus impacts are likely to any of the wetlands at any wi the sites during the construction phase of the project.

\subsubsection{Operation}

No impacts are tikely to any the the wetlands at any of the stites during the operation phase of the project. Since the placement of equipment will be arvay from the wetland areas. thete would be no activity at any of the wethand sites. Furthermure, since the fucilities would be constructed away from the wetland areas (even auxiliary and extended sitest. opperations bake place away from the wetland areas ind these areas would be avuided.

\subsubsection{Floodplains}

\subsubsection{Construction}

Evaluation of the thoodplain information tor the central and beundary facilities revealed that flucdplains exist for the McClatin County (Purcell. Oklathoma) boundary fucility (the proposed site and Alterratives 1.2 and 3), the Okmulgee County (Haskell. Oklahoma) boundary ficility site (peopesed site and Alternatives 1.2 and 3). and the Marion County (Hillsboro, Kansas) boundary Eactity sife (proposed site and Alternatives 1 and 2). Floudplain information on Kiowa County has 
not been devetoped by any agency. Figures 1,10 and 1,11 show the areas atfected by the Eloodplain tor these tucilities. Since only 1.5 ures need to be disturbed in these quaner sections of 160 atres ( 160 acres, of which 50-100 acres are needed for the boundary tacility), ample room femains for placement of the instrumentativn within those quarter sections, away from the thodplain areas. These floodplain areas, identitied in Fig. 1.10,1.11 and 1.14, would be avoided during the construction activities. In that sentse, eath of the proposed action and atternative sites is atceptable from the viewpoint of thoodplain impacts. In summary, given that designated flowdplation areas in the proposed and alternative Okmulgee and McClain County boundary sites would be avoided, each of the sites is acteptable.

The criteria tor choosing the auxiliaty and extended sires also require the avoidance of

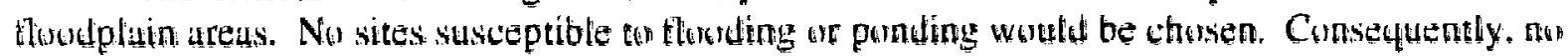

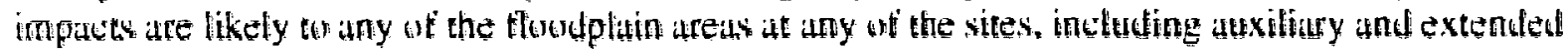
sires, during the construction phase of the project.

\subsubsection{Opgration}

No impats are tikely to any of the thendplain areas at any of the sites, ineluding auxiliary and extended sites, during the uperation phase of the project. Since the fiacilities would be constructed away from the thoodplain areas. operations wauld take place away from the floudplain areas and these areas would be avoided.

\subsection{Alt Quality}

\subsubsection{Construction}

The placement of instrumentution at the centrat. butundary, auxiliary, and extended tacilities involves unly a smatl amount of construction activity that cordld lead on air emissions. In facto the actual area involved in surtuce disturbances at eath of these sites is no more than 1.8 acres and anly one small tractor (for grading) would probably be used aleng with a gravel dump truck and a cement mixer. Since a water truck would be used to minimize the fugitive dust through the use of a seray system. only a negligible amount of at emissions whuld ucieur upon placement of these

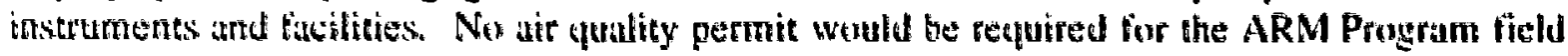
wonk from either the state of Kansas ur the state of Okbuhma. However. the state of Oklahwoma requires that fugitive dust emissions be controlled even if the subues is nut permitted by its regthatiens. This exepuirement is part of Regulation 3.1. entitled "Pertaining to the Control af

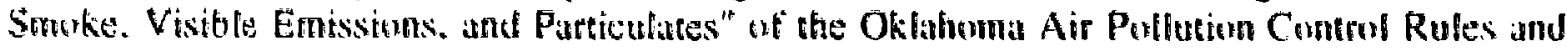

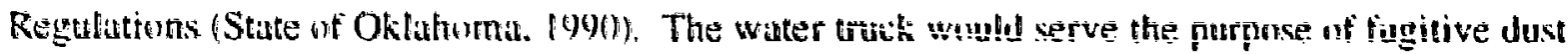
emissiuts cuntrol. with an expected $50 \%$ reduction in fugitive emissions due to periudic watering. 


\subsubsection{Oporation}

Actual operation of the instruments over the ten-year period from alli sites would lead to no air pollutunt enissions. Only exhaust trom the vehictes of the workers at the site would be afded to the air. Air quality regulations would be maintained on the busis uf this very low level wt activity.

The decommissioning plant atter the ARM fielt work is completed is to restore etch of the disturbed areas to is original land use. Decommissioning tirst involves the removal of pads, piefs; and alt strutures trom each of the sites. The next step is the replacement of topsoil and then the

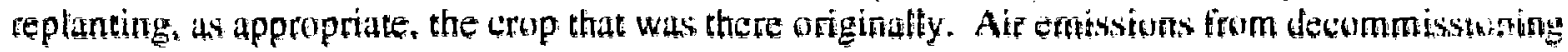
would also be smatt (on the urder of the emissions from the constructon phase) as equipment is

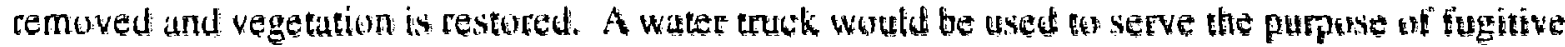

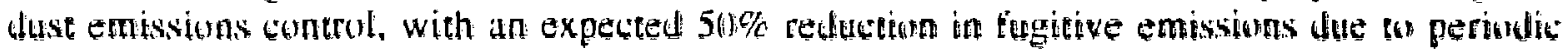
watering.

\subsection{Nolse Impacts}

\subsubsection{Construction}

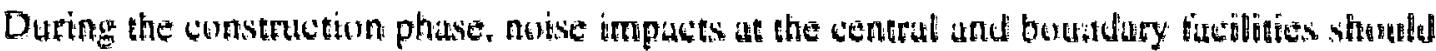

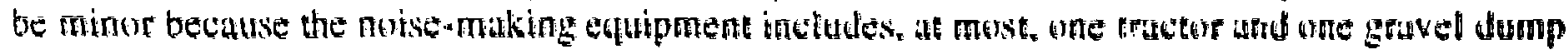

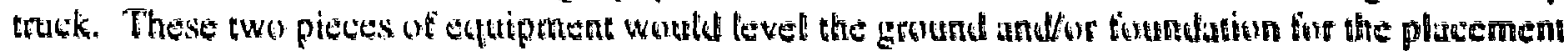
of equipment andone traters. When one instement has been pusitioned at a site. consuruetion equiprtont would move to another location within the site tor plucentent another instrument or lacility. Impacts of nuise from these pieces of equipment ard from the autmubiles whe workers traveling to and trom the site would be negligiole. One of the initial actings would be pliscement af most of the mobile humes (one each tor the 5(1)-MHz and 915-MHz profiter/RASSs) and semicratlers. Various other insturnents and semi-trailers would be placed intermietenty during the hrst yetar.

\subsubsection{Oporation}

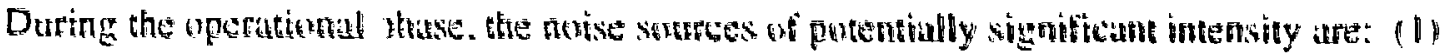

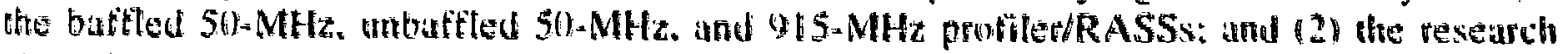
atront "routine flyovers" and "special intensive campaigns." The inpaces from ole protilet/RASSs witl be discussed torst, followed by the impaces from the atreratt.

\subsubsection{Protiter/Rass operation}

The prottler:RASSs can have significant impacts if they are sited ton close to nearby residentes. The unbatted 50-MHz and the 915-MHz protiler/RASSs are being propnsed fir the 
central tacility, while the baftled $5(j-\mathrm{MHz}$ and the $915-\mathrm{MHz}$ protiter/RASSs are being proposed tor the boundary tactities. Both 50-MHz profiler/RASSs (batfled und unbattled) emit a tone like it tontinuous toghorn (at a trequency of about $100 \mathrm{~Hz}$ ) for a period of 5 min. once per hatf hour from up to three transducers positioned about $50 \mathrm{~m}$ apart. The $915-\mathrm{MHz}$ profiter/RASS emits a continuous tonal sound in the 2,000-Hz frequency band for $5-6$ min. every 39 or $60 \mathrm{~min}$. The 915-MHz protiler/RASS has four transducers that emit sound simultenteosisy. Information provided by personnet involved in the operation of such profiler/RASSs elsewhere in the U.S.

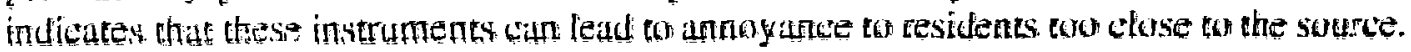

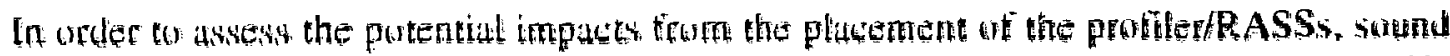

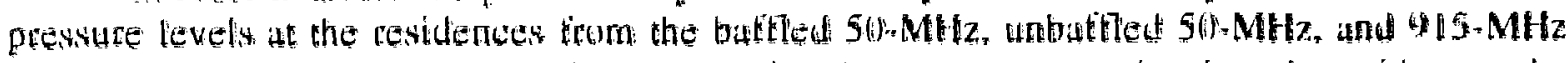
protiler/RASSs afe required. In order to derermine the susund gressure levels at the residentes, the tollowing utres pleces of intormation wete needed:

1. The location of the residences trom eateto wh the protpused and isternative protiler/RASS listations, two the cented ind busundary butilities.

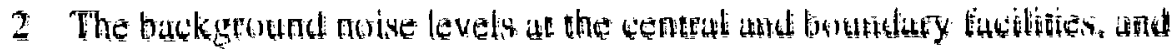

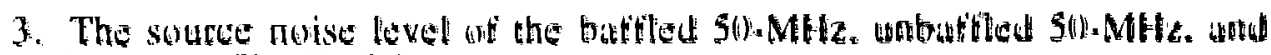
915-MHz protiler/RASSs.

Appendix E provides the infurmation required in (b) above. Nusise duta were collected in a twho phase noise study that involved the meisurement of the barkground ambient novise levels as the

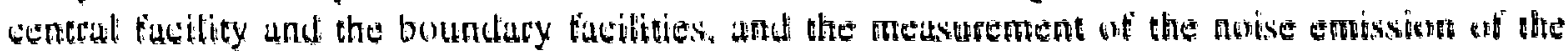

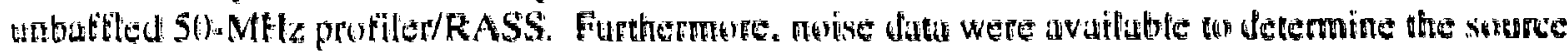

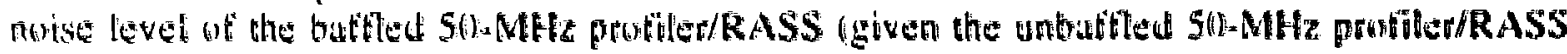

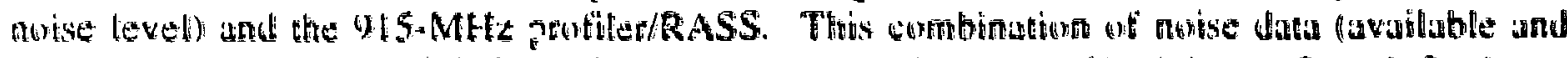

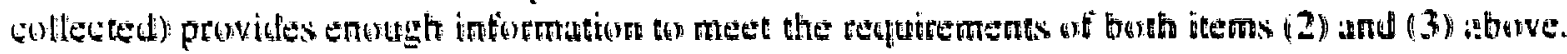

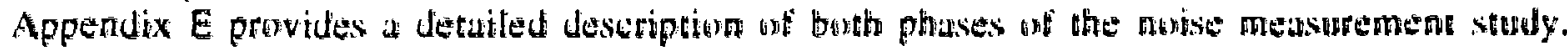
including id beiet discusstun al arise terminulegy.

Concerning the background ambient notse metasurements acquired at the central tixcilley and

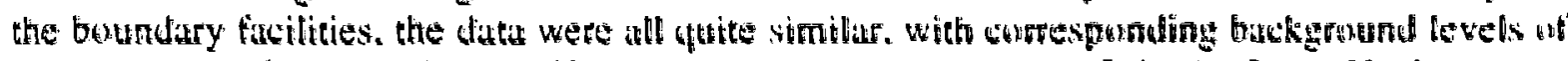

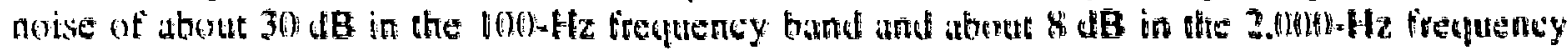

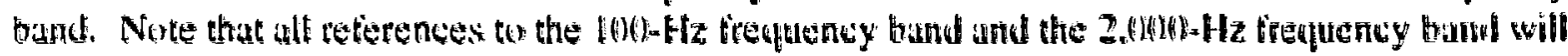

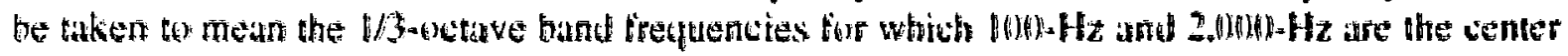
frequencies, respectivety.

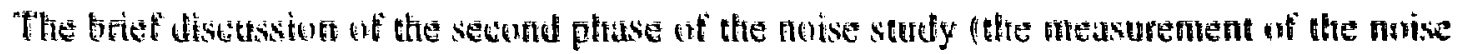

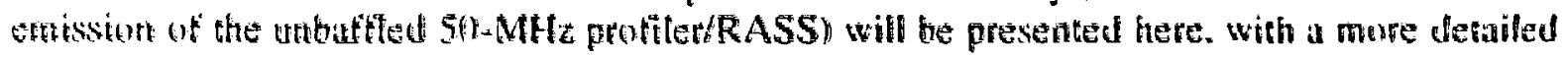
discusstert in Appendix E. Sound around and unbaffled 50-MHz protiler/RASS that was in operation (with twe tronsducess operting stmultanemusly) was measured in Coffeyville. Kansas. in Decentber 1991. Meastrements at a distance of $133 \mathrm{~m}$ from the centroid of the two-speaker system sthowed a sound pressure level of $78 \mathrm{JB}$ in the $10 \mathrm{M}-\mathrm{Hz}$ trecquency band. Uising the Edison

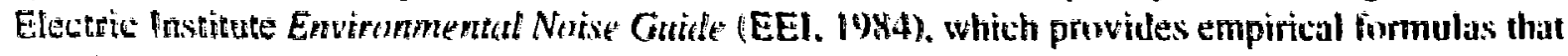

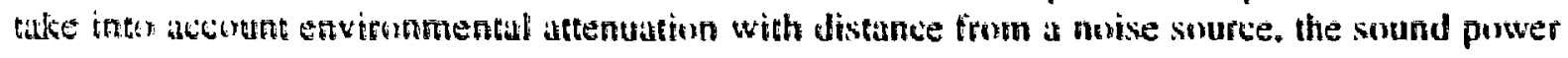


level of the sulfee was estimated to be $129 \mathrm{~dB}$, at the centrois of the $50-\mathrm{MHz}$ protiter/RASS. Since the actual 50)-MHz protiler/RASS that would be used would have three speakers insteall at at two, the sound pressure level is increased by $2 \mathrm{~dB}$ to $131 \mathrm{UB}$ (see Appendix E).

Radian Corporation personnel (Vik, last) carried out similur medsurements for a $915-\mathrm{MHz}$ profiler/RASS in Austin. Texis. The measurements by Ratliun Curp. the Manufuturer) were taken at if wide range of disunces. The measurement tuben it its $m$ trom the

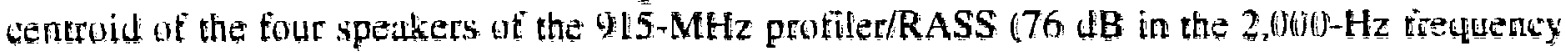

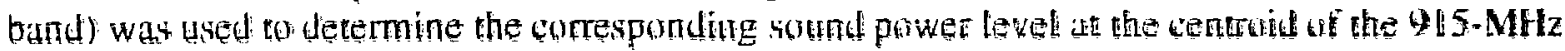

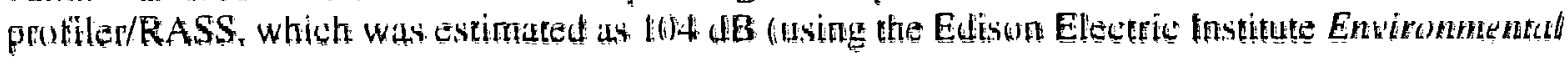
Novise Guidte's empiricul formulat).

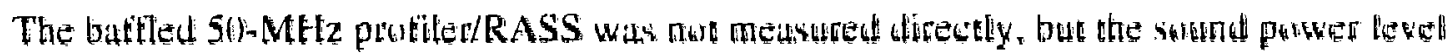

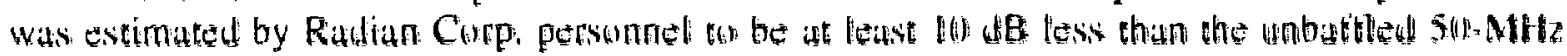

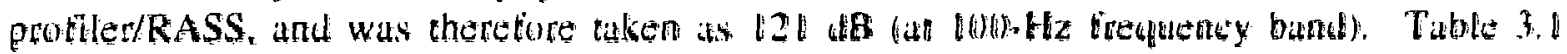
summurizes the sound power tevel of the thee profiler/RASS.s.

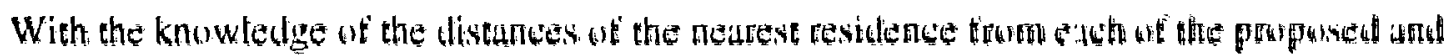

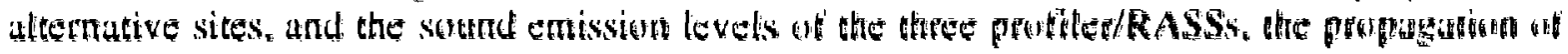
sound from cach protiler/RASS to the nearest residence wats predicted using the empirical formoliss

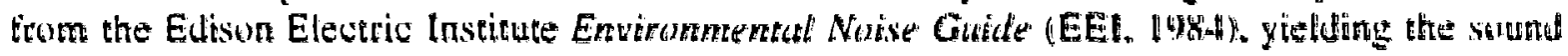
pressure levels at the various restdences. Predictions of sitrnd pressure level as a function onf

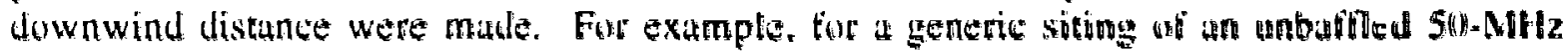

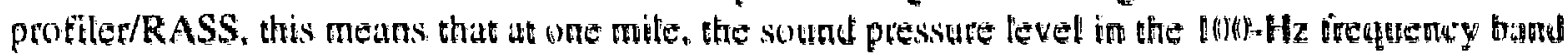

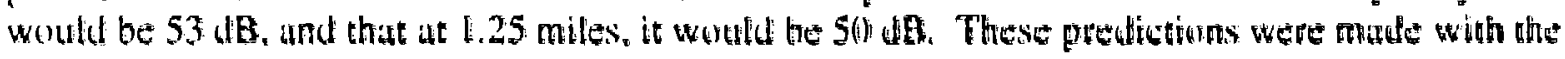

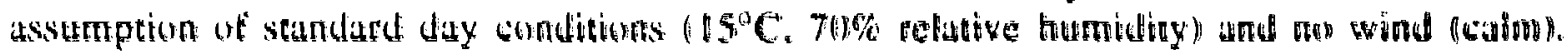

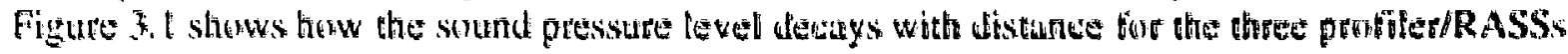
of interest.

Once the background ambient noise levels and the prential sound pressure levels an the

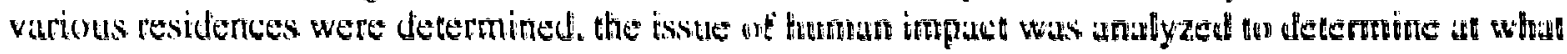

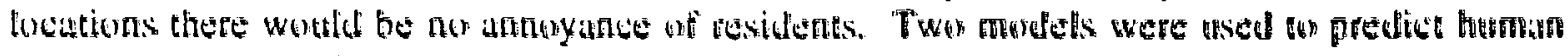
annoyance due to noise.

A model of commently anneyante. the mortitied Conposice Neise Ruting (CNR) metherd

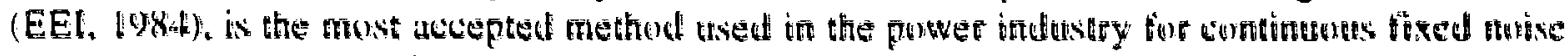

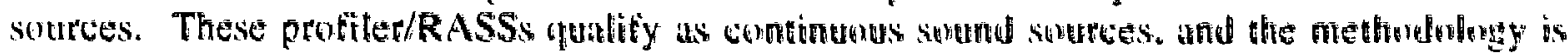

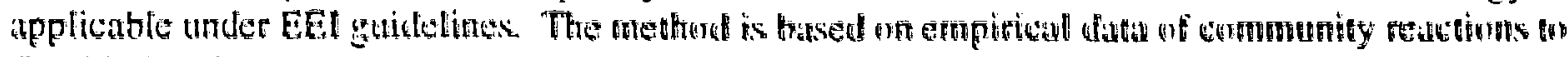

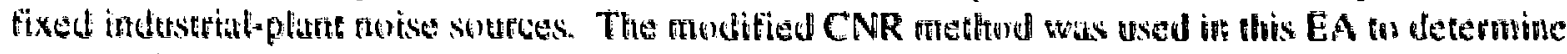

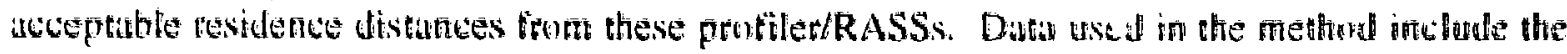
firllowitig:

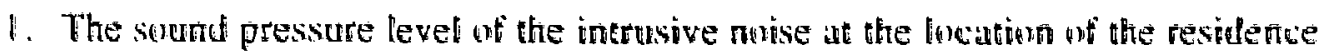
and the residual enviromental ambient notike levels. 
Table 3.1 Sound Fower Level of the Various Profiler/RASSs

\begin{tabular}{|c|c|c|}
\hline Protiler/fas & $\begin{array}{c}\text { Frequency Band } \\
\qquad(1+z)\end{array}$ & $\begin{array}{c}\text { Sound Power lievel } \\
(\text { (d) }\end{array}$ \\
\hline Baffled $50-M H z$ & 100 & 1121 \\
\hline (Uחएatflod); $50-M H z$ & 100 & 1131 \\
\hline $915-M H_{2}$ & 2,000 & 104 \\
\hline
\end{tabular}

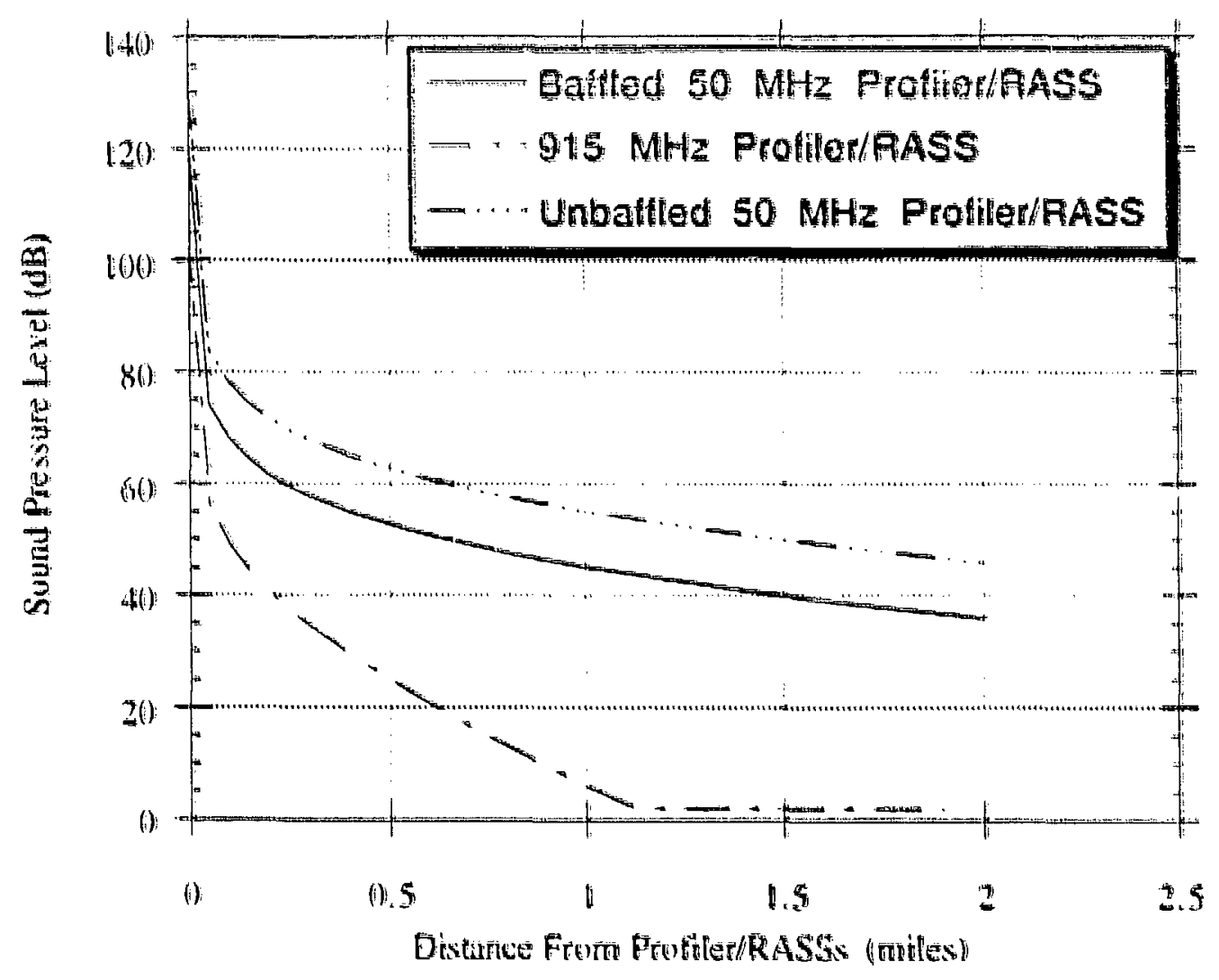

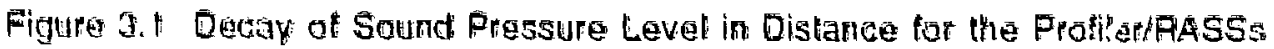


2. The characrer of the nuise source fi.e., whether it is e: very low frequency, its tonal tharacter, and also its intermittency (the ratio of source "on" time to it reterence time of, say, $l$ h) I. Included also are seusonat (winter, summer), operational, and other temporil factors (daytime or nightime unly).

3. Subjective tactors such as previous exposure history of the community to that noise surec and community attitude.

The dewalts of the modifted CNR analysiss are given in Appendtx E. A CNR fating of "C" (which represents an average community response between "ant retution, althongh nanse is

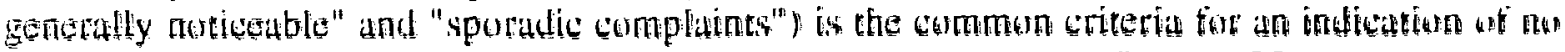

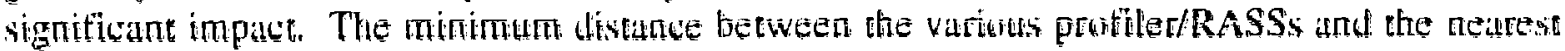
residence in srder to avoid a CNR rating gretuter than " $C$ " is presented in Table 3.2. For example.

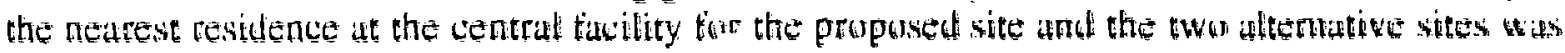

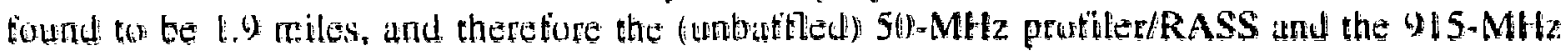
profiler/RASS are accepuble. Af all we the boterdary tacilities, the proposed sites and some of the atternative sites have a nearest residence greater than 6,54 miles atway, and therefure the battled 5()-MEtz protiler/RA3S and the 915-MHz protiler/RASS are ateceptable.

A model of individual (rather than commetnity) annoyance was alsen used ton supplement the results of the modified CNR method. This model is the psycheacoustic method of Fidell 10987 . 1988). This model was used as a supplement to the medflied CNR tindings, in order we verity that sites fiund to be acceptable by the CNR mudel would alsw be acceptable by this model. The Fidell model. a new and difierent type of computer mudel. was applied to the issue at siting the

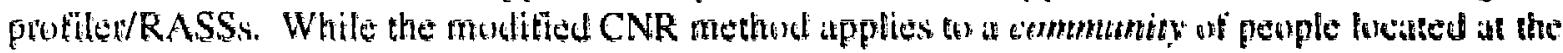
residentiat location of interest. and its predictuns reter to likely reatetiens of the temenunity. the

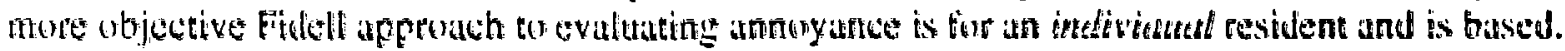
in part. on certain psychological attitudes of that individual resident. Analyses that fircus un a

Table 3.2 Minimum Distance between Prafiler/ RASSs and Nearest Residences, as Predicted by the Modified CNR Method

\begin{tabular}{|c|c|}
\hline Profilom/aAss & $\begin{array}{c}\text { Minimutu Oistamce to Avoid } \\
\text { Advorse Impacts } \\
\text { (miles) }\end{array}$ \\
\hline Eamed $50-M k-$ & 0.54 \\
\hline (Unbaffled) $50 \cdot M \mathrm{Klz}$ & 1.30 \\
\hline $9+5-M H z$ & 0.30 \\
\hline
\end{tabular}


particular individuall, require the input of individual characteristics that atfect that person's reaction to noise. Among the variables required in this Fidell model are the following:

1. The "atfected state" of the individual (the individusl's view of the project as unitavorable. neutral, or tavorable).

2. The individual's levef of concentration on ongoing activities, being focused on the disturbance, on neither the wisk at hand or on the disturbance, or only on the tark itt kund.

The above twe variables, in combination with the sound pressure level of the profiler/RASSs and the background ambient stwand pressure level. can be used to predict the prebability of an individual's annoyante. The Fidell methwd results supported the tindings of the muditied CNR method (see Appendix E for details).

The overall results of the muditied CNR method are presented in Tuble 3.3, with in detited discussion in Appendix E. Table 3.J shwws the ateptable (A) and undeceptoble ob sites for locating the profiter/RASS:. This table uses the muditiet CWR method, wnd gives the limiting predictions tor the cases studied here. The andlyses and predictions made indicate that at the proposed sites, the proposed action (which is a tembinution of protiler/RASSs. including 11 ) for the central tacility. an unbatfled 50-MHz profiler/RASS allong with a 915-MHz protiler/RASS. and (2) for each of the botndary facilities, a batfled $5(\mathrm{k}-\mathrm{MHz}$ profiler/RASS and a M15-MHz protidler/RASS) does not produce any significint novise impats.

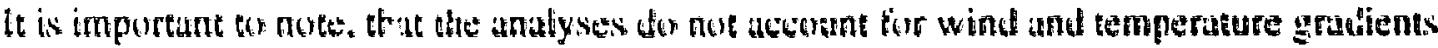
that are tristat in the atmosphere. If the wind is blowing from the resident oo the source nuise levels should be much lower than predicted abonve or perheps even inaudible. thepending upon the distance between noise sotrce and residence. On the ather hand, if the wind is blowing toward a nearby residence from a protiler/RASS. the effect of wind and tempertute gralients may fead on the temporary increases in noise levels. Downwind propogation of novise due to retiruction of movise due to inversion conditions (espectally at night) do nccur and may lesd to nccasional increases in noise levels tar from the source. but these increases are very transitory fat a fixed location downwind) Jue to the strongly time-varying nature of the air flow. Variations in noise levels due to wind and temperature gradients cannot be precisely predicted at this time because data on vertical tenperature and wind protiles are not available for these sites. Predictims mate here for perinds of nor wind und standiud daytime conditions previde the best single estimates. but nonetheless they have a large standard deviation.

Finally, the moditied CNR method is a comprehonve approme to commenity response dte th a continutous futse soures, and therefore includes the times when community members are attemipting sleep. The Fidell method. which was used to support the tindings of the mudified CNR method. was cun for as variety of conditions. including an attempt or model the annoyance of an individual dutting the nighttime (see Appendix E). 
Table 3.3 Acceptable (A) and Unacceptable (U) Sites for the Profiter/AASSs According to the Criteria of the Madified CNA Method for Acceptability of Noise Impacts

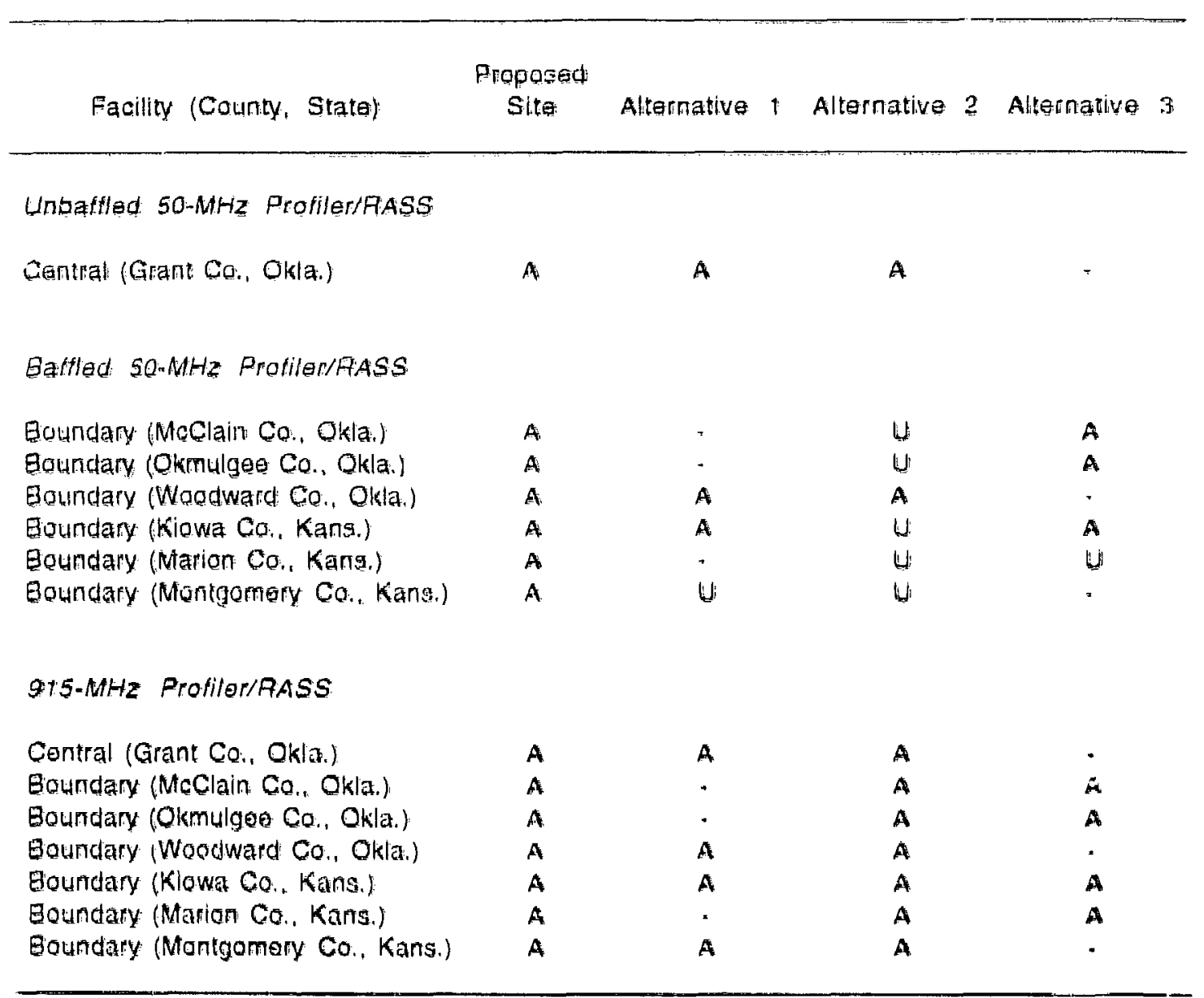

\subsubsection{Aircraft Operation}

The "routine Hyovers" and "spectal intensive compagns" of the researth aircraft have the potential for causing annoyance for people on the ground if the lights are coro low and/ur directly uver nearby residences. Five arreraft the P.3 Ortan, the G/ Gulfistream, the King Air C.9n. the Deffavitand Twin Oter DHC-6. and the Cessna) are candidate type aircraft that herve been proposed to tly special resegreh missiens at the central and boundary fichities. An evaluation of the tmpacts of these tights would largely be with respect to novise on the ground. The situation leading co the greatest noise impact would be the 2-3 intensive measurement periods per year. One or twi ot the above atroratt type would tly at 500 feet above ground level for either several $20 \mathrm{~km}$ legs over the centual factlity iocation or two $425 \mathrm{~km}$ legs that criss-cross over the entire CART si!e. Such tight paths would be chosen to avoid towns and homes as much as possible. This section evaluates potential impacts of these thyovers. Twe noise metrics were used as indicators of potential impact due tu aircratt operations. using the NOISEMAP 6.0 model (Horonjeff et al.. 1974)). Althotght the jet aircrati will not be used at $500 \mathrm{ft}$, all tive aircraft were (for completeness) compared at an altitude of $500 \mathrm{ft}$. and tor the purpose of this analysis. tight paths were assumed to 
be firectly uver a residence (worst case scenario). In addition, flight paths at various transverse distunces from a residence $(500,1000$ and $2506 \mathrm{ft})$ were also considered.

First, the day-night average sound tevel $\left(\mathbb{L}_{d n}\right)$, was used to predict the community effects of long-term exposure to environmental noise. Noise levels below 65 dB $L_{\text {dn }}$ are considered to be compatible with residential land use. The most tommonly used measure of aggregate community response is the percentage of people in a populated community who are "highly annoyed" by the nuise (NAS 1977: Schultz 1978, U.S. EPA 1982). Tuble 3.4 gives estimates of this percentuge of high annoyance in if populated community as at function of $L_{\text {dnh. }}$

Table 3.5 gives the predicted $L_{\text {dn }}$ levels fur the varius wirtuth asing the NOISEMAP arodel. Nune of the predicted tur values exced 65 dB, which is the level considered th be cumpatible with residential land use. Furthernore, the wnly arregat that predicts any percent of the

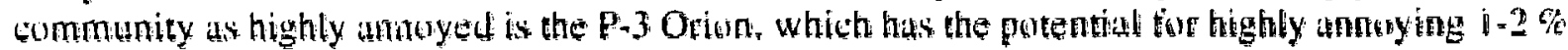
of the people when the aicurat is tlying within an ofiset of about 500 ) it. It is important to keep in mind that the flight paths muy vay. ss it wotuld not be a dited trettight every time. No nightime

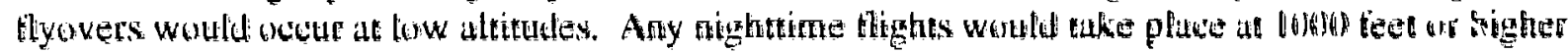

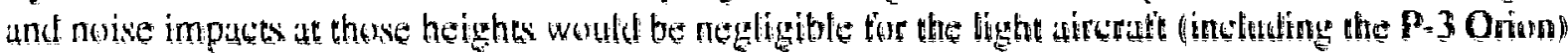

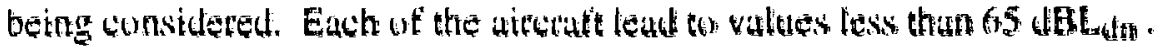

The second metric by which the impact of atreraft operations was measured was the Lenas value. which is the maximum A-weighted sound tevel occurring doring in single airorall uperation. The $L_{\text {max }}$ value is used to assess the level of speech interterente thring the flyover an 5 orth it.

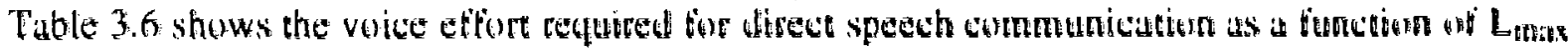
value and the distanes between the individuals communicuting.

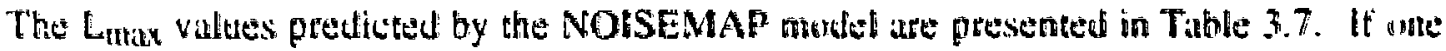
number is to be used from Table 3.6. an $L_{\text {mrix }}$ value of 65 ab is generally considered as the threshold for speech interterence. As cun be seem. any direte onserbead thight woruld poudate sume

Table 3.4 Highly Annoyed Percentage of a Populated Community (U.S. EPA 1982)

\begin{tabular}{|c|c|}
\hline $\begin{array}{l}\text { Ledn Level } \\
\text { (da) }\end{array}$ & $\begin{array}{l}\text { Porcoml of Connmumily } \\
\text { Highly Annoyed }\end{array}$ \\
\hline 45 & 1 \\
\hline 50 & 2 \\
\hline 55 & 5 \\
\hline 60 & 9 \\
\hline 65 & 15 \\
\hline 70 & 25 \\
\hline 75 & 37 \\
\hline 00 & 53 \\
\hline 95 & 73 \\
\hline
\end{tabular}


Table $3.5 \mathrm{Lcm}$ Level for the Various Airctaft at Different Offset Distances

\begin{tabular}{|c|c|c|c|c|}
\hline \multirow[b]{2}{*}{ Airclate } & \multicolumn{4}{|c|}{ 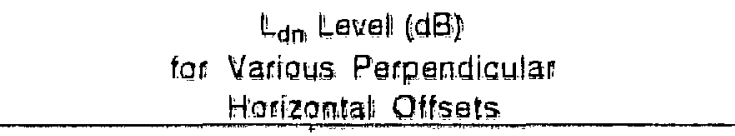 } \\
\hline & 0 & $500 \mathrm{tt}$ & $1000 \mathrm{ft}$ & $2500 \mathrm{ft}$ \\
\hline P.3 Orion & 40.5 & 45,9 & 42.0 & 34.2 \\
\hline G1 Gulfaream & 31,3 & $28.60^{\circ}$ & 24.0 & 13.6 \\
\hline King ir c-90 & 30.0 & 27.9 & 23.3 & 12.9 \\
\hline Twin: Otter DHC-6 & 38.9 & $3 \mathrm{a} .2$ & 31.8 & 21.9 \\
\hline Cegsna & 33.3 & 30. & 25.5 & 14.6 \\
\hline
\end{tabular}

Table 3.6 Veice Effort Fequired lor Direct Spench Communication as a Function of Maximum Intrusive Noise Level (Lmax) and Distance between Individuals.

Distance

belween

Talkat and

Liatener

$(1)$
$E_{\text {max }}$ (dB) Fequiring Increased Volce Elfonts

Normal

Faimod

Vory Loud

Shouting

$\begin{array}{ccccc}0.5 & 01 & 97 & 93 & 99 \\ 1 & 75 & 91 & 97 & 93 \\ 2 & 69 & 75 & 91 & 97 \\ 4 & 63 & 69 & 7 & 81 \\ 6 & 59 & 65 & 71 & 77 \\ 12 & 53 & 59 & 65 & 71\end{array}$

$t_{\text {max }}$ is the groatest A-woightod sound level of inumeding lairenatt) roise.

Sources: Beranok 1947, 1971, 1998; Kyter t994: Nowman and Beatlio 1995: Woustar 1969a.b. 
Table 3.7 Lmax Level for the Various Aircraft at Different Offset

\section{Distances}

\begin{tabular}{|c|c|c|c|c|}
\hline \multirow[b]{2}{*}{ Alrefat } & \multicolumn{4}{|c|}{$\begin{array}{l}L_{\max } \text { Level (dB) } \\
\text { tor Various Porpendicular } \\
\text { Harizonlal Offsats }\end{array}$} \\
\hline & $01 \mathrm{t}$ & $500 \mathrm{ft}$ & $1000 \mathrm{tt}$ & 250.0 it \\
\hline P-3 Orion & 93.3 & 89.9 & 0.4 .9 & 75,2 \\
\hline Q1 Gulfatream & 76.5 & 73.5 & $6 \theta, \bar{T}$ & 59.8 \\
\hline King Air C.90 & 76.5 & 73.3 & Gi: 7 & 59.9 \\
\hline Twin Otter 3ale-6 & 82.2 & 79.0 & 74.6 & 66.2 \\
\hline Cugana & 72.9 & 594 & 64,4 & 5.5 .1 \\
\hline
\end{tabular}

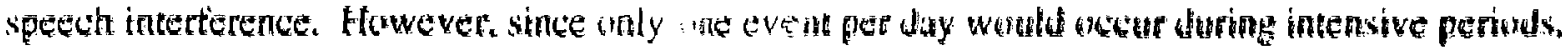

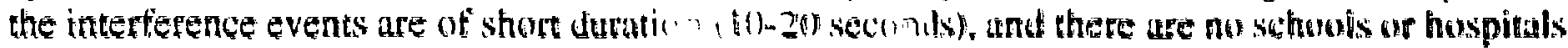
nearby the tlight path. impacts would be smiti!

Finally. each of these aircrate tlly shwly during their low-level nights (about $120-150$ knots). The possibility of a startle effero is negligible thecintse at these slonw spceds. people on the ground would have udequate warnin: tom an aircraft will pass by. Startle eflects are

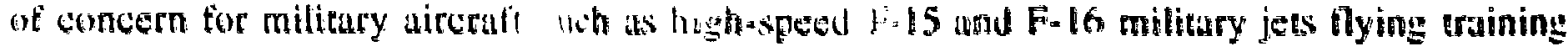
exercises in low-level goutes. It aty be conctuded that waly a unce per day speeth interference would vecur for people under the thight path. One may saty, shumary. that the impacts from the operation of the research airctaft appear in be small and very infrequene whishever aircraft is used tor the research flights.

\subsection{Biolic Resources}

The primary impacts of the proposed actian un biotic resutedes would aceur during construction of factity access rouds, concete trabler pads, parking areass. the RASS. and equipment anchoring piers.

\section{5.t Vegetation and Wildife}

Adverse impacts to vegetation would be limited to areas excavated for power lines and trailer pads: augured for equipment piers and fence posts: and graded for parking areas. RASS deployment, and access roads. Access roads (driveways) to the central facility and each of the boundary fucilities. which would be built perpendicular to an existing section roud and would be only tong enough to slear utility easements along the existing road. would be approximately 30 it lonieg and $15 \mathrm{ft}$ wide $(0.0) !$ acres). These driveways would lead to the mobile homes. rawinsonde. 
and storage area at the central tacility and to the rawinsonde and storage areas all the boundary tacilities. No eads er graded paths woutd be built to atcess individual equipment at any of the central, boundary, auxiliary, or extended facilities. Sacrificed vegetation would primarily consist of grasses and some other herbikeus species. However, the impats of construction activities to vegetation are likely to be low becanse the areal requirements for piers, pats, equipment, and parking areas are small (see Appendix B). The U.S. Department of Energy would provide at qualified biologist to conduct a pedestrian survey af these areas to be disturbed before cunstrution begins.

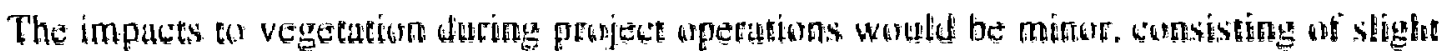

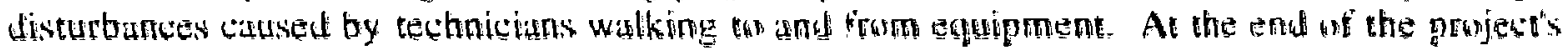

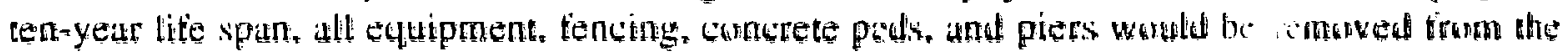

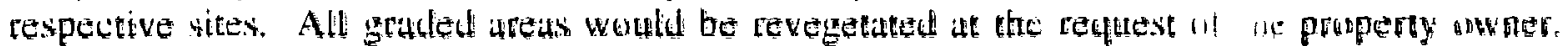

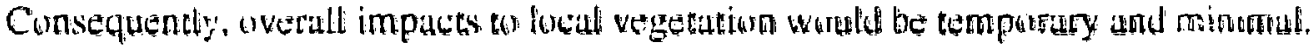

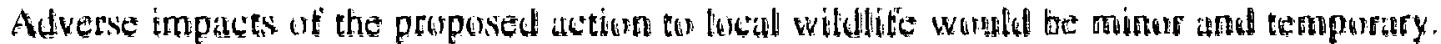

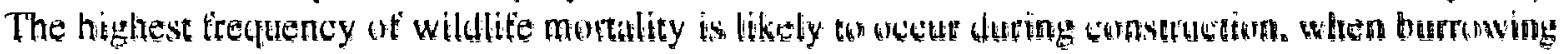

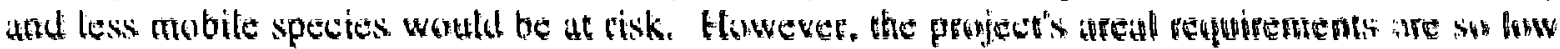

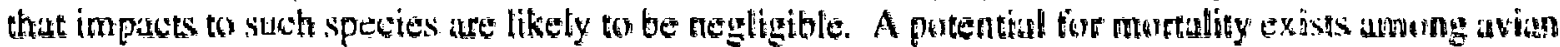
species (collisions) once project structures hive been erected. but mutigative meastres suth ass installation of thorescent gay wire sleeves woblu be implemented. Aduitiunably " a blinking light

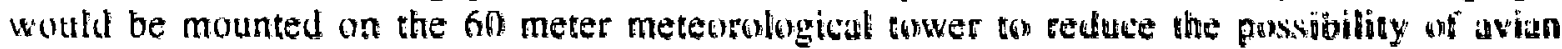
coltisions. Further, the vertical noise sorurce would be plated as fir as cechnically teasible away

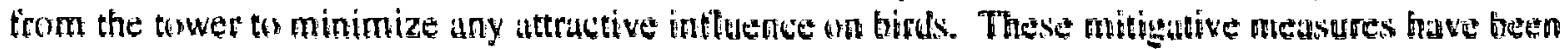

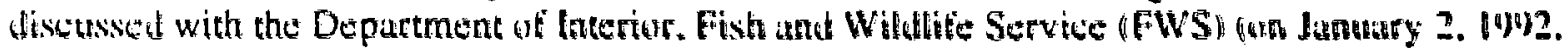

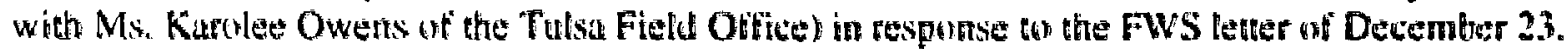
1962 (see page D-14), and are chansidered to be an alceptable solution by FWS to their previuus

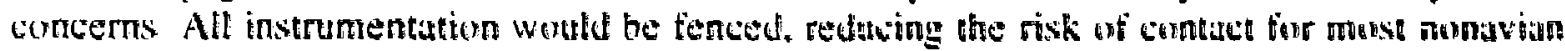

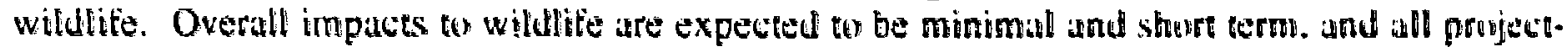
related structures would be removed upen the project's teminatinn.

\section{5.t.t Ettects of Noise on Birds}

A porential impact on birds including both breding birds and migratcory birds in thight is

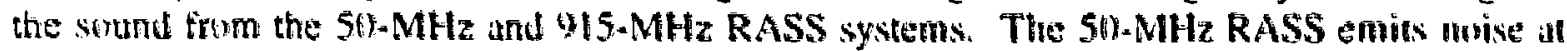

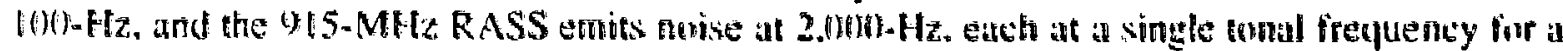
period of 5.6 min. every 30 ar 60 min. of RASS upertitum. The range of maximum sensitivity of

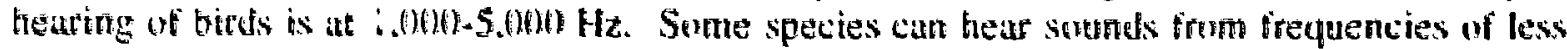

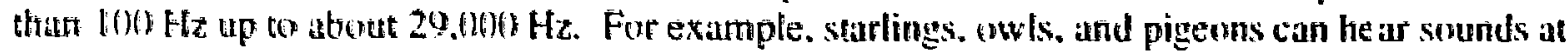
frequencies as low as $100 \mathrm{~Hz}$. Becanse hearing may play an impontant folle in bird m gration. the RASS noise could disortent a bird as it thiss in the sound field. However the sound field. originating from the ground level. attenuates rather rapidly with distance (by 6 dB for each doubling of the distance). In adution, the birds may siniply avoid the sound rielu. Some birds misy be attracted to a sound souree. while other birds may be repelled. Birds have been known to tly into at all antenna or a call tower with attached guy wires. Mortalities could nccur if birds are 
attracted to such is sound source. For the ARM study, the sound is emitted from transducess ath the ground. Two or three transducers would be needed for the 50-MHz RASS and four transducers for the 915-MHz RASS, At the central facility, if 60-m tower would be present, but that tower would be located at least $100 \mathrm{~m}$ trot the RASS systems.

Aftuther persibility is that breeding birds tound be distubed by the sound and coufl tail to use uvailable breeding habitat. On the other hand, birds cuuld become habituated the sormal. Phy itglogical responses and reduced hatehing and tledging ancess huve resuled from exposure th nuise: such data were obtuined experimentilly and reluke ton aircraft tlyovers. The literingure on

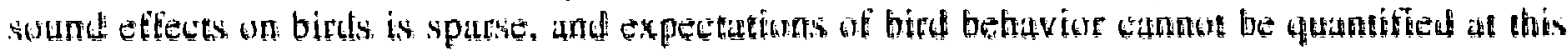

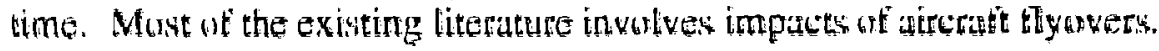

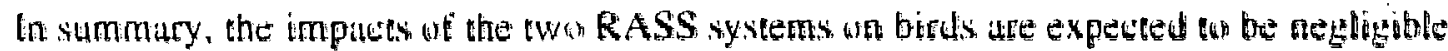
because the 6it-m ewer is relatively shore, and must migrang birds tly higher than the height of

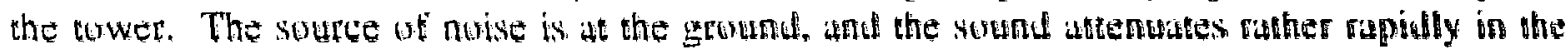

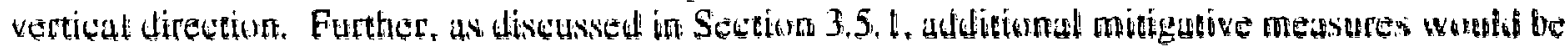

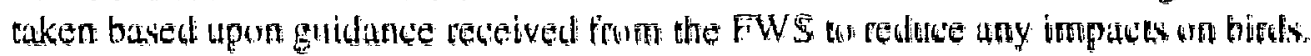

\subsubsection{Impacts at Nolse on Domesticated Animals}

Noise elicits behaviugal and physical reactims in domestic livestock similar tah thwse onf

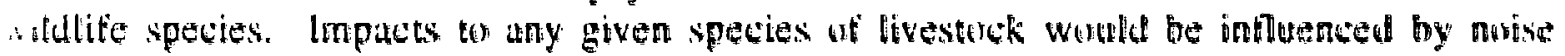
characteristics. duration. bearing ability of the animat. and tamiliarization of the animals as the

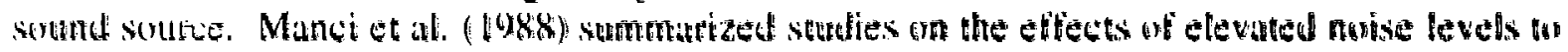

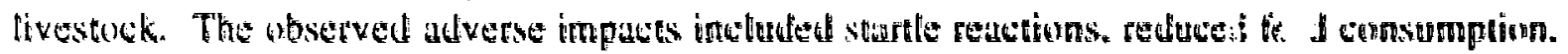

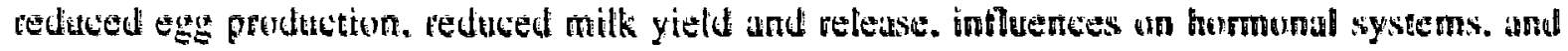
increases in heart and respiratory rates. Mtrst of these effects have been ubserved for nesses levels aborve 9() AB. The RASS systems emit noise for 5 mint every hall hous. and the impacts of thin

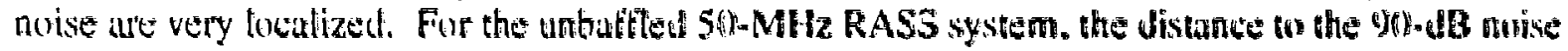
ievel is abe et $40 \mathrm{~m}$ : the distance is 13 an tore the batlled 5h-MHiz RASS system. For the 915- $\mathrm{MHz}$ RASS system, the distance to the 96-4B norise level is abut 2 m. Many of the propersed sites for the centrat and boundary fucitities are in pasture land or fangeland: e.g. the prophed site and

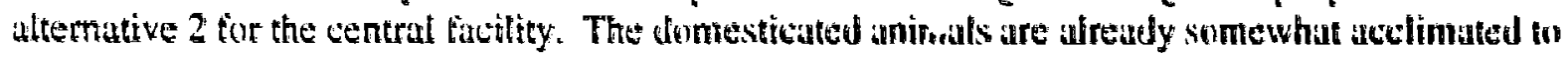
disturbances beciuse cars and tarm vehicles pass them periodically. The presence of the RASS systerms would afd propentionately to the annwynce surently experienced by the domestitated animals in the near vieinity of the RASS systen. The balled 56) MHz RASS system (planned for use at the boundary lacilities) would be surromeded by a fence that would include a circle at $13-m$ radits: the 915-MKtz RASS system also has a fence that includes the 2-m-radius 90-4B contour. the untaftted $5(1-\mathrm{MH} \vec{z}$ RASS system (tor the central facility) is surrounded by an fence. but the fence is not large entough to cover a 40 -m circle. That small area toutside the fence but inside the

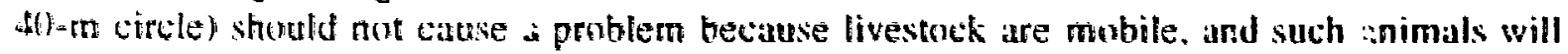
probubly become acclimated to the noise in time. 


\subsubsection{Threatened and Endzangered Spacies}

The Kansas State Office ot the FWS has detemined thet the proposed and altemative boundary facility sites in Mongomery (Neodesha, Kansas) and Marion (Hillsboro, Kansas) counties would not adversely affect federally listed endangered and threatened species (Gitl. 194lb). The proposed and altemative boundify facility sites in Kiowo County (Haviland, Kansas) are in an area where migrating whopping crane and black-footed ferret may accur. However. neither the wetand habitat that supports whoping cranes aur the prairie dog town rangeland

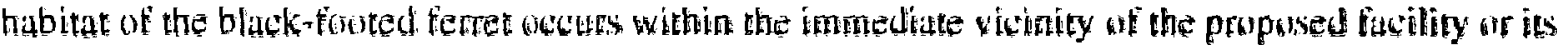
ulternatives.

The Eculogical Services branch of the FWS aftice in Tulsa indicuted that the project was

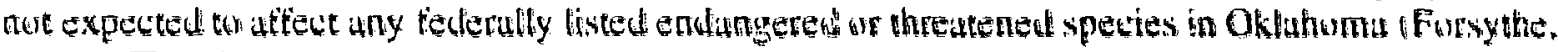

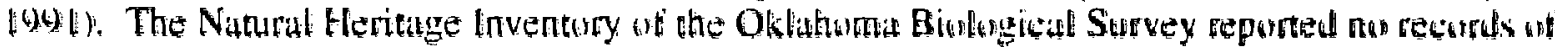

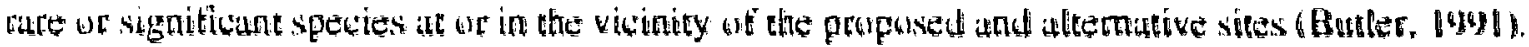

\subsection{Land $\mathbf{U} 90$}

The proposed action is uot expected to duersely athect existing or tubure land use. The propused central facility and each of the propesed boundary fatilities are lucuted in rural seltings.

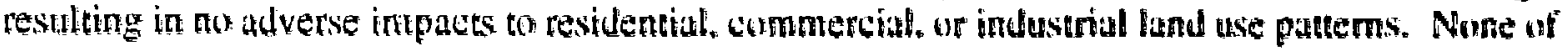
the proposed tactities would violate extsting lund use plans or zoning conteds. Pipelines that pass

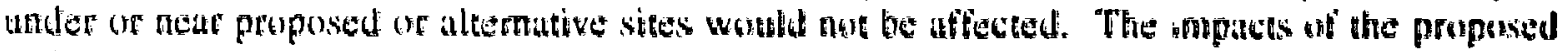
astion on prime farmland are atsen expected to be minimat. since tewer than three areses would be disturbed of oceupied by instruments at the centrat tacility. and less thin two ateres woud be disturbed or occupied by instruments at the boundary factitues (ses Appendix B). At eath auxiliary

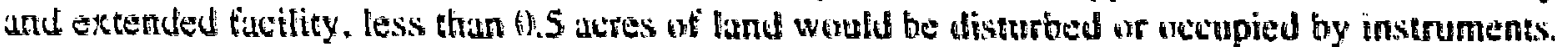
Upon sompletion of the project. all tand within the borders of each facility that would be utilized

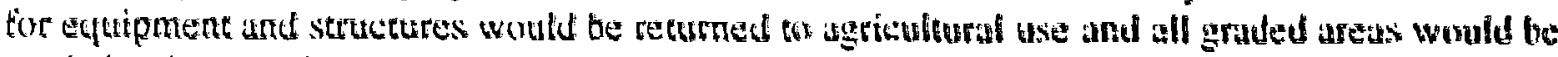
seeded or kept in place. acourding to the wishes of property owners.

Land ourside the pertmeters or the proposed sibe's facitities would be affected only during consteturion. when coads around the factlitiss would experience a slight increase in iraffic. Many at these roads are anpaved. but the slight increase in tratitic during construction is expected to have negligible impatts. During operations. ionpacts o land outside the perimeters of these faxilities would be negligible.

No afolitignal adverse impats to fand use are anticipated with the altemative facilities, since their clase proximity to the proposed facitities would result in almost identical impacts.

\subsection{Visual Resources}

Vtsuat impacis to the scenic envirnnment sumounding the proposed central and boundary facilites (ant thett altermatives) during construction and operation are expected to be low. As 
Jescribed in Section 2, the landscapes serrounding the central facility and several of the boundary facilities are relatively uniform. lacking a wide variety in landform, vegetation, and color. No unique viewsheds would be adversely affected.

The tallest structure in the entire project the central fucility's 60-m meteorntogical tower. would be visible for several miles from viewpoints surounding the proposed fucility and its atkernatives, Howevef, two sommunications towers afe already visible on the western horizon from viewpoints in the victinity of both the proposed central facility and its alternatives.

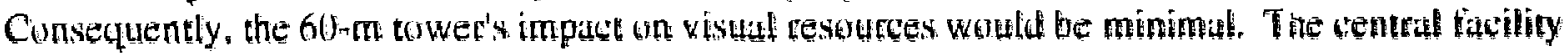
would also sontain it $10 \mathrm{~mm}$ walk-up tower that whuld be visible from several middleground (distances of $1 / 4-2$ miles) viewpoints, but its inteusiton onto the tandseape would be negligible.

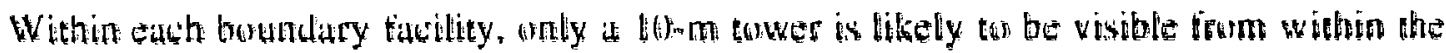

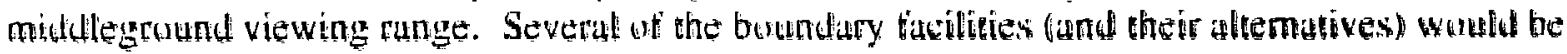
locuted in township sections cuntuining Nutisnal Oceunic and Atmespheric Administration MOAAn

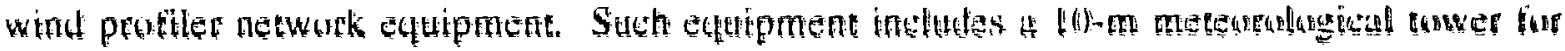

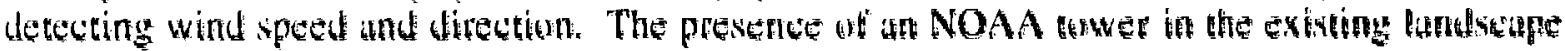

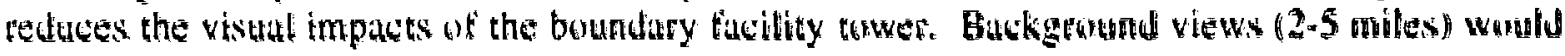
not be affected by the boundary facilities.

No visualty sensitive receptor areas such as residential developments, parks, schmols. trails, state forests, or recreational fictities woth be visublly atlected by the proposed tacilities or

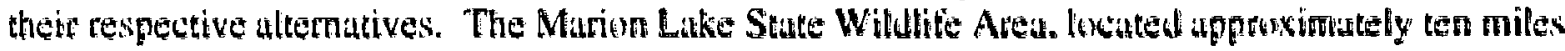

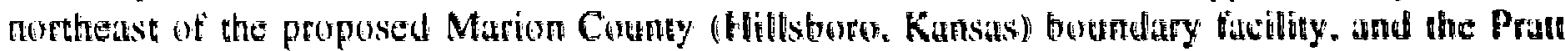

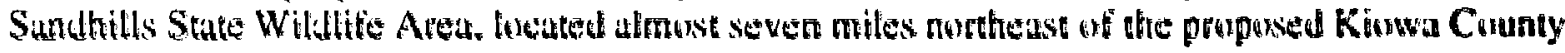
(thaviland. Kunsas) boundary facility. whetd not be affected by the proposed action or its afternatives. The Elk City State Park and State Wildbite Area of Mentgontery County (Nendeshis.

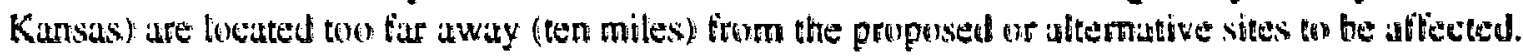

\subsection{Cultural Resources}

The OKlahona SHPO and the Kansas SHPO have continmed that the propused attion would have no adverse impacts an cuttural resorurces (Geltys and Brooks. 1991: Pankratz. 1991). The prepesed boundary facility and its altematives in McClain County (Purcell. Oklahoma) were lecated in a region that holds a potential for prehistoric sites, but a servey of the proponed site. conducted on December 17 by the Oklathoma Archeologitusl Survey. revealed no evidence of prehistrnic sites (Getlys and Bronks, 109/b). The Kansas SHPO indicared that the lower elevations of Stony Bronk, lecated in the quarter section containing the proposer, boundary facility site in Merton County (Hillsburo. Kunsus) might hold prehistoric sites. Hovever. the facility would be licuted in an area of higher elevation. away from the sensitive parcels.

If archeolugical remains are encountered Juring project construction activity at any of the proposed facilities, the appropriate SHPO would be contacted inmediately. The U.S. Department of Energy would have a qualitied expert present during construction to make such determunations. Operations in the various facilities would not impact cultural resources. 


\subsection{Socloeconomics}

No adverse social or economic impatts would tesult trom the proposed action or its alternatives. Some short-tem econonic benefits would result during the construction phase of the project. but these would be limited to brief periods of empluyment ind to lowal purchases at building materials. Althugh the precise number of workers required for construction hus not yet been established, the size of the work crew is expected to be approximately $10-20$ fincluding ARM Program personnel installing the actual instuments) for the central facifity and 3-5 for each

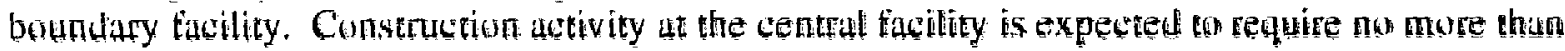

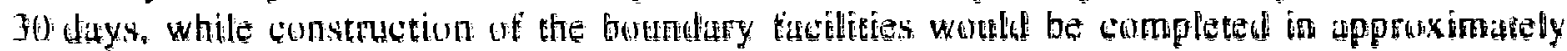
iwo weeks.

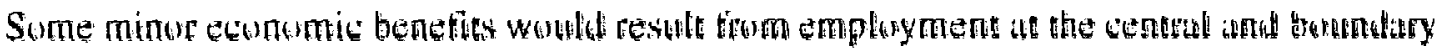

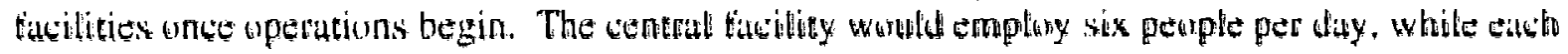
boundary tacility would eraploy two persons per dhy.

\section{3.t0 Health Etfects on Site Personnel}

Each of the site workers whuld be spectidly trained nut only in instrument service und maintenance but also in environmental, satety, and health issues. As part onf ahe ARM Prosaram Satety Plan for operutions at the stuthem Great Plains CART site. DOE would provide

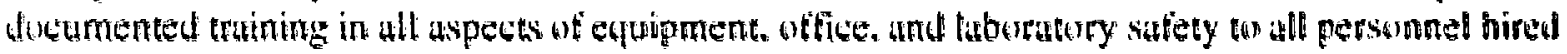
for site uperations.

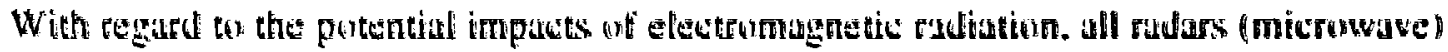
and lidars (laser light) are located in semi-trailers. Thase trailers are specially designed to have sheret metal skins and are grounded. This treatment shields the electromagnetic radiation by reducing or eliminating the tadtation teom the ponwer stredces that run the initruments. All nom-eye

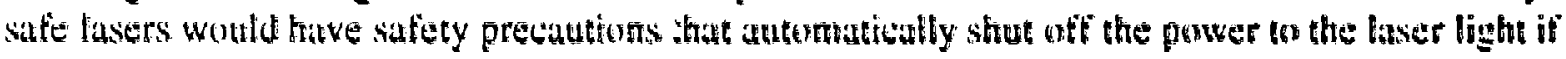
any obstacle comes into the potential path of the laser bight.

The possibility for accidents aftecting workers and the public ape extemely low. The lidurs would be eye-sate ard the remathing equipment puse no spectal denger during constrution or operation. The peblic will be kept from entering the instrumented areas by the fentes around that equipment and by warning signs on the property rented by DOE.

\subsection{Waste Treatment and Disposal}

Only the certral facility wand be enceupied on a regular basis. The buundary. auxiliary. and extended sites would be visited pericudtably for maintenance and the atquisition of the collested Jata. For the sentral facitity. a septic tank system would be installed: otherwise all other solid waste wortd be transported from the site by a commercial firm. No hazardous waste would be created at any of the sites. 


\subsection{Unavoidable Adverse Impacts}

The issue to be addressed in this sectivn is whether there are any unituiduble adverse impacts that could leat to the need for an environmental impact statement. Considering that mitigation has been buift into the proposed action including baftled grotiler/RASEs in the boundary sites), there are no unavoidable adverse inpacts that could terd to the nee f for an environmental impare study. There are, however, some small impats such as very octasiomal

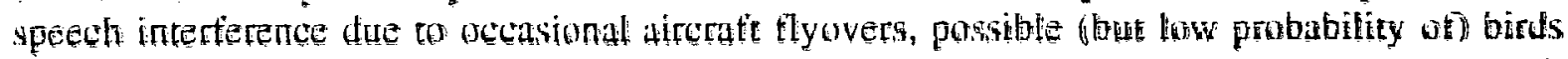

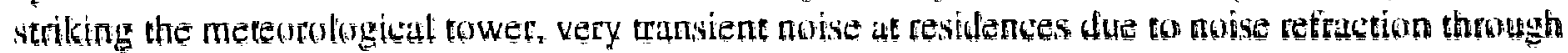

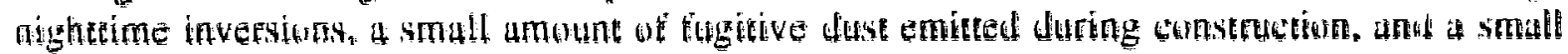

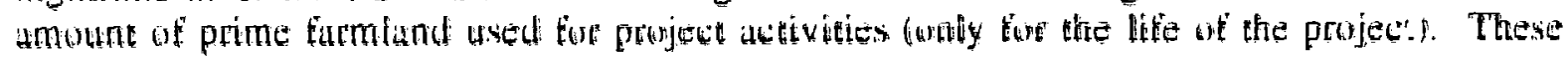
impacts are very minor, however.

\subsection{Comparison of Alternatives}

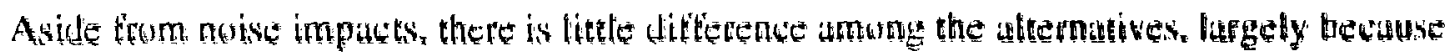

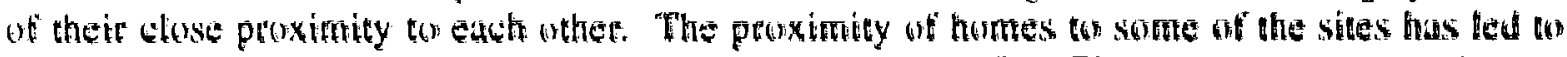
putentially important nuise impats (ateorting to the muditied CNR criterion). even with the buffled 50-MHz RASS system. The perentially impatted boundary tucility sites are the Altemative I site tor Mongomery County, the Alternative 2 sites in MuClirin. Okmulgee. Kiowa. and Marion Counties, and the Alternative 3 site for Marion County. These sites would have much greater noise impacts than the other besundary site cunditates and would not be used.

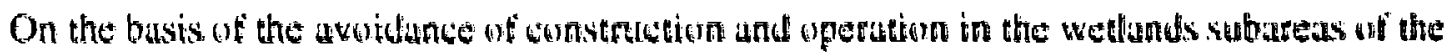
MoClain County cundidute sites und in the thyodplain subareas of the McClain and Okonulgec Cosnty sites. all candidates are equally preterable. The placentent and monitoring of inseruments could be carried aut satistactorily within subareas of the Miclain and Okmodgee Cunndy. Oktahoma. candiditte sites.

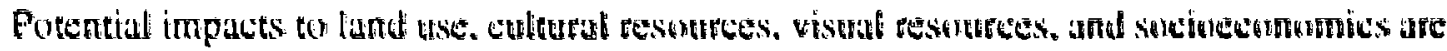

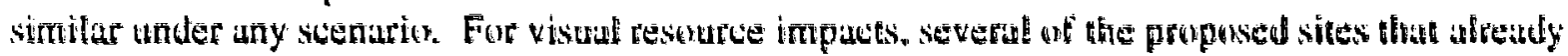
contuin NOAA protiler equipment (MoClinen. Murtern. and Montgamery Countiesh may be prefertable to their tespective altermatives.

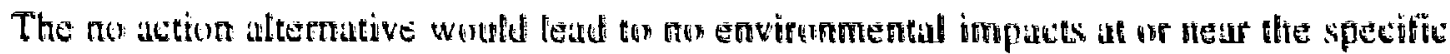

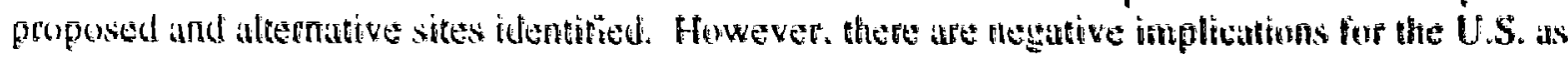
if whete of ne ARM fiedd studies of this type in the U.S. First. all setentifte information which

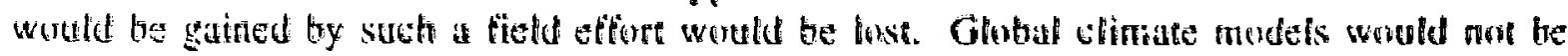
inturerved leading to consideratie uncertinties in the magnitude of the glowal warming phenomenon: in addition. the validity of the global chimste models used for both scientific and policy analysis would rentatr cuestronable. Consequences of the use of pow or unvalidated moteling tonts could lead to a pore projection of the future magnitude of suspected global warming

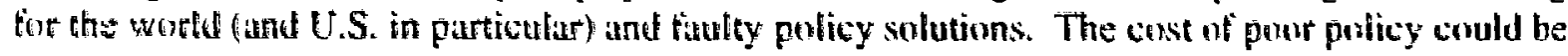


very large and have very negative impacts to the long-term future of the U.S. Seconth, if no artwn is translated into requiring the choice of a site outside the U.S., there would be imposing logisticut

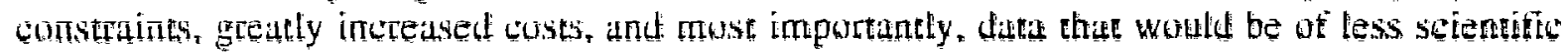
value.

\subsection{Cumulative Impacts}

The potentiat for cumulative imputs has been exumined with it tinding that there ante nu

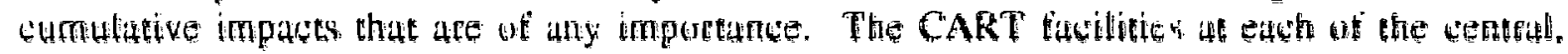

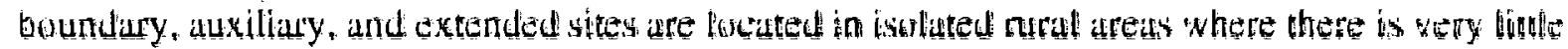

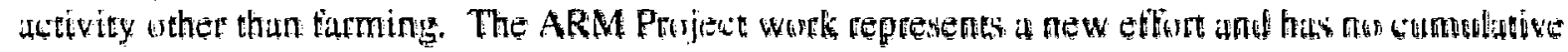

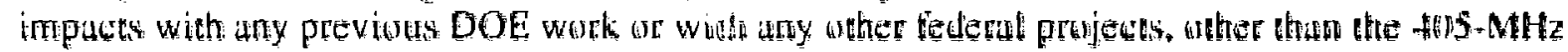
profiler network at 5 of the boundary sites (us mentiuned earlier). A separate envirmanental assessment bad been prepared priur to the siting of thuse $405 \mathrm{MHz}$ protilers. A review of that

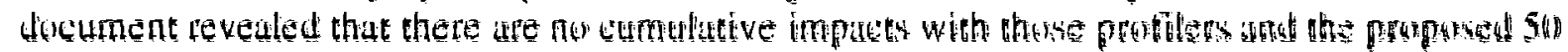

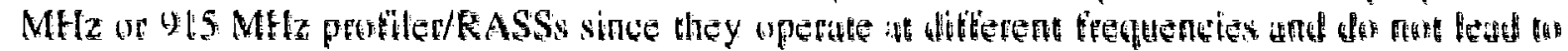
adlitive affects. 
3.25 


\section{Sumnary and Conclusions}

In this EA the impacts of placement and operation of meteorologital and fadiation measurement equipment were evaluated within separate areas of one centrat facility ( 160 acres), up

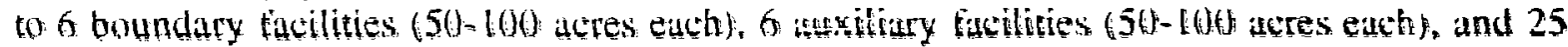
extended facilities (50-100 acres each). The actual disturbed area would be 1.8 acres for the centrat facility and 1.5 acres tor each of up to 6 boundary tiacilities. Less than 0.1 atre would be disturbed at each of the auxiliary or extended sites.

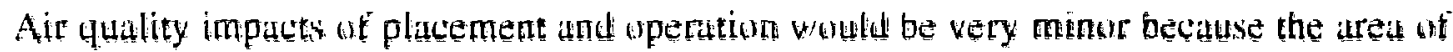

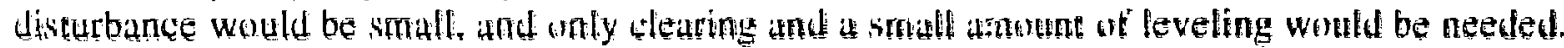

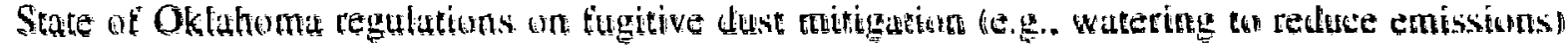
would be followed during the connitruction.

Noise impats to nearby residents were exaluated throught acturl tield measurements at ambient restidual environmentul noise. mousurements of the surtand pressure levels of the 50 and

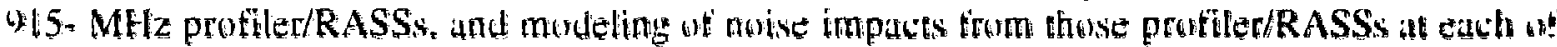
the proposed and atternative sites. The tesults showed the fublowing results in tems at move impacts:

1. The 50-MHz and 915-MHz profiler/RASSs were tound to be wecepuble at the central facility for the propossed action and each of the altematives. The baffied 50) MHz profiler/RASS and the 915-MHz protiled/RASS are acceptuble ar the boundary sites except for Alternative I for Montgonery County: Altemative 2 for McClain. Okmulgee. Kiowa. Marion, and Mongemery Counties; and Alernative 3 for Marton Cerenty. The batfled 5()-MHz protiler/RASS allows the neise to be nore muthled and reduced int intensity by at least $16 \mathrm{~dB}$ trom the unbalted 5t)-MHz protiter/RASS. The buttled system is an gowd chuice at the boundury facilities becutse of the clowe proximity of resitlences. At least one site was found to be acceptable for the battled 50-MHz profiler/RASS at each of the six botndary fictitites.

2. The 915-MHz RASS system wass forend to be acceptuble at all proposed sites and altematives. including the central taxility and the six boundery tacilities.

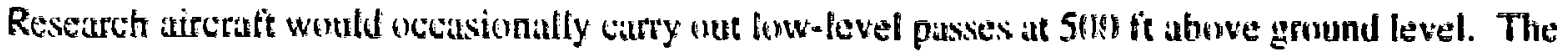
prepesed arreratt would cause momentary speech interference for peuple under the hight path. a minner impact.

Water tesouted impacts would be very minor. with the following grovision for the Okmulgee Cetnty and McChain County boundary sites: No construction or aperational activities whetd be carried out in specifted subportions of the McClain County boundary facility sites (proposed site and all three altematives) and in the okmolgee Connty proposed site and Alternative 2 beciase of the presence of a floudplain. However. the wetlund area is a subpontion of the theodplain, which is to be vaid of construction or operational activities in any case. 
Impacts to vegetation and wilciife would be tow and temporary. Most impacts would weur during the short construction period. No threatened or endangered species would be at risk.

Land use impacts would be very low because of the limited areal requirements of the project. No more than two acres per tacility site would actuatly be disturbed, und land use in the vicinity of the project would not be arfected.

The project impacts to visual resources surtumeding edeh site would be low. The only structure in the entire project that would be visible from a vantage point of greater than two miles woutd be the central tacility's 60-m meteordingital tower. However, other man-made structures are visible on the horizon west of the proposed site.

The impats to cultural resoures would be minimal. The stute historical peservation ofticers (SHPO) of Okbahomat and Kansas indicated that none of the proposed or afternative sites for tacilites contain structures or sites listed in the National Register of Historic Plates. The luwer elevation of the Marion Councy (Kansiss) sire may conatain archenlugicul sites, but these areats would be strictly avoided.

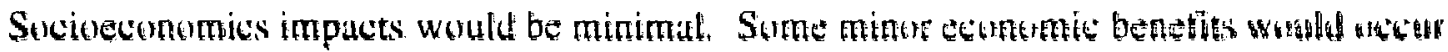

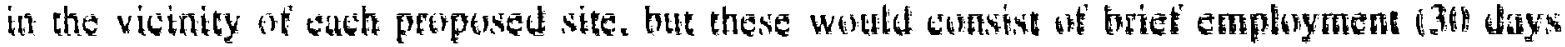
maximum) tor only a tew workers during sonstruction and the focal purchase at suppont muterials.

The auxiliary and extended sites have not been located at this time. The positioning of stuth sites would be made by using the list of strict criteria (with no protilet/RASS system at these sites) described in Section l. In addition. since siting is very ftexible for these fucilities. imprets wombl surely be very small.

Becatse the ARM Project activities would take place only in rural areas that have mo tandustrid or commercial activities, which wothld portentially be intertered by on interfere with ARM activities. cumulative impaess would be negligible.

The no action atternative would be the loss of a U.S. site. which wathl be detrimenual or the scientific steddy of global warming. The loss of the U.S. sitte weruld severely limit the ahility of the project to vastly improve models and to make appropriate pulicy decisions om global climate change. 


\section{References}

Barr $\mathrm{S}_{\mathrm{x}}$ and D. Sisterson. 1991 , Preliminary Logistical Analysis of Patential CART Lacales for the Continental United States, Locale Specifici Report: Southern Great Plains, Einal draft report. Pacitic Northwest Laboratory (October).

Beranek, L.L.r 1947. The Design of Speech Communication Systems, Proc. Institute of Ratis Engineers, 35:880-890.

Befanek. L.L. 1971. Criteriat for Noise and Vibration in Commennities. Buildings, and Vehickes. Chaptef 18 in Novise and Vibration Controsl, L.L. Beranek, ed. MeGraw-Hill, New York, pp. 554-603.

Beranek, L.L., 1988, Criteria for Noise and Vibratiom in Communities, Buillings, and Vehiches. Chapter 18 in Noise and Vibration Controh. Rexised Editionn. L.L. Befanek, ed.. Institute un Nonise Control Engineering, Washingtom. D.C. pp. 544-623.

BLS, 1991, Locat Area Statistics, U.S. Department of Labur, Washingewn. D.C.

Butter. 1.th. 1991 . Letter from Oktahoma Naturat Heritage Inventory. Oklahoma Bishogical Survey, to J.M. Ptingston. Argonne National Laboratory (November 20 ).

EEl (Edison Electric Institute). 1984, Electric Power Plant Envirummintal Noisq Guidt". Second Edition. Washington, D.C.

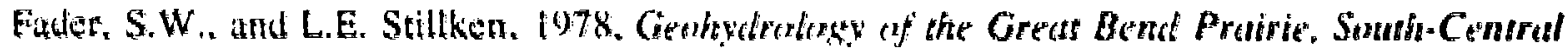
Kunscas. trigigation Series 4. Kansis Geolugical Strvey and The University of Kansas. Lawrence. Kunsiss (May):

Federal Interagency Committe for Wetland Delineation. 1989. Federal Monual for ldentifing and Detineating Jurisdictional Wetlands. U.S. Army Corps of Engineers. U.S. Envirunmental Protection Agency, U.S. Fish and Widtite Service. and U.S. Sobl Conservation Service. Wastington. D.C.

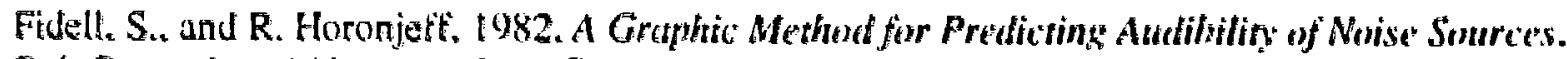
Bott Beranek and Newman. Inc.. Canuga Park. Callitornia. U.S. Air Furee Repurt AFWAL-TR. $82-3086$ (October).

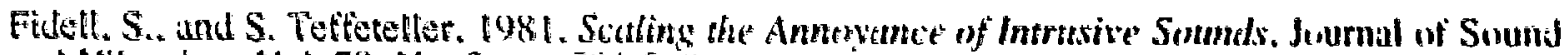
and Vibration. Vol. 78. No, 2. pp. 291-208.

Fitelt. S. D. Green. and K. Pearsons. 1987. A Theoretical Model of the Amnoremer of Individual Notise tritrusions. Paper presented uratly at the 114 th Meeting of the Acoustical Suciety of America (November 20). 
Fidell, S., D.M. Green, T.J. Schultz, and K.S. Pearsons, 1988, A Strategy for Understanding Noise-Induced Annoyance, BBN Laboratories Incorporated, Canoga Park, Calitomia, U.S. Air Force Report HSD-TR-87-013 (August).

Forsythe, S.W., 1991, Letter from Ecological Services, U.S. Fish and Wildite Service, Tulsa, Oklahoma, to J.M. Plingston. Argonne Nationat Laboratory (Decrmber 3).

FWS (Fish and Wildtife Service, U.S. Department of the Interior), 1992 , Personal correspondence with Dan Mulhem. Biologist. Manhattan, Kansus (January 21)

Gettys, F. and R. L. Brooks, 199lb, Letrer trom Oklahoma Archeological Survey. University ant Oklahorna, Nurtwan to I.M Ptingstun. Argunae Natisnal Laburatory (Detember 17).

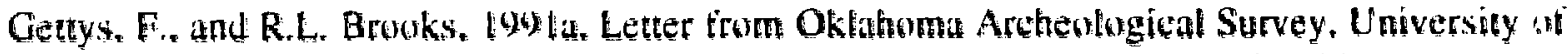
Oklahomat Nerman, to f.M. Ptingsten. Argenne National Latoratoy (November 19).

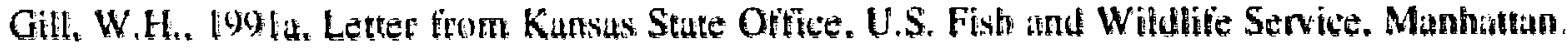
to J.M Ptingston Argonne Natisnal Laburatury (October 23).

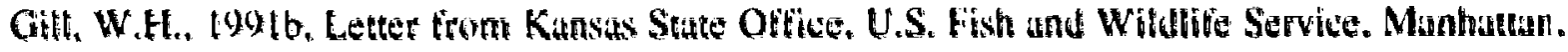
wo J.M. Pringston. Argonne National Laboratory (November 25).

Eturunjett, R.D. R.R. Kandukuri. and N.H. Reddingius, 1974. Commeming Nerise Expmsure Resulting from Aircraft Operations: Computer Progrom Description. Armstrong Aerospate Medical Researeh Laboratory Report AMRL-TR-73-169. Wright-Patterson Air Furce Base. Ohio. Prepared by Bolk, Beranek and Newman. Ine.. Canuga Park, Callit. Nov.

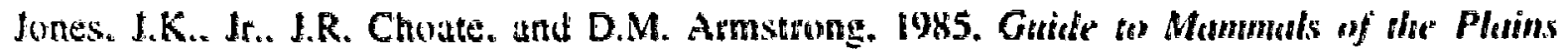
Stutes, University of Nebraska Press. Lincoln. Nebraska.

Kraxner, A., [991. Personnel Communication. Photocopies of pertinent material from Water Well Reeords, Kansas Department of Health and Envirunment - Division of Environment. Topeka. Kansas.

Kryter. K.D. 1984. Physiological, Psychologicat, amd Sircial Effects of Nriser. National Aeronatics and Space Administration Report NASA RP.1115. Langley Research Center. Fumpton. Va.. July.

Manci, K.M. D.G. Batdwin. R. Villella. and M. Cavendish. 1088. Efferess of Aircrafi Nowise and Sentic Beems on Domestic Aninats and Wildlife: A Literature Synthesis. U.S. Fish and Wildlife Service Report NERC.88/29. U.S. Air Fore Report AFESC TR-88-14. Fort Collins, Colloradn. (Juthe).

Newman. J.S., and K.R. Beattie. 1985. Aviation Noise Effects. U.S. Department of Transportation Report FAA-EE-85-2. Federal Aviation Administration. Washington. D.C.. March. 
O'Connor, H.G., 1974. Gealogy and Ground-Water Resources of Montgomery County. Syutheastern, Kansas, Ground-Water Series No. 1. Kansis Geological Survey and The University of Kansidi, Lawrence, Kansis (September).

Pankrantz, R., 199l, Letter from Historic Preservation Department, Kansas Historital Suciety, to I.M. Ptïngston. Afgonne National Laboratory (December 2).

Fearsons, K.S., S. Fidell, R. Horonjeti, and S. Tetieteller, 1979, Noticeability and Annovante of Electrical Power Transformers in Urban Nosise Backgrounds, Bolt Beranek and Newnan Repont 4004, Canoga Park, Calitomia.

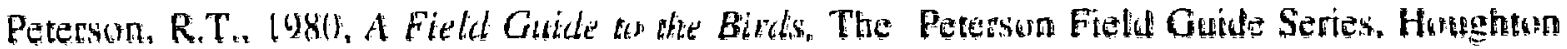
Midetha Cir. Burstun.

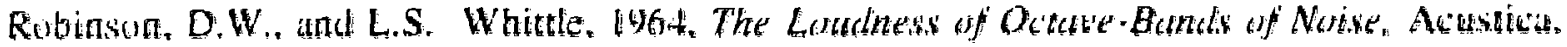
Vol. I $\hbar_{\text {. No. }}$ l. S. Hirzel Verlag. Stutgart. Germany.

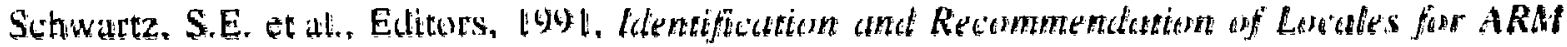
Sites. (April).

SCS (Soil Conservation Service, U.S. Deparment of Agricultored. IMul. Persmal conrespondence with Clarence Miller. District Conservationist. Independence. Kansas (November 20).

Shatfer. J.M. 1991, Letter from Grant County Commission, Grant Connty. Oklahoma. on J.M. Ptingshn. Argonne National Laboratury (December 2).

SRt International. 1956. Envirommental Asscssmbent .. Wind Proffiter Demonstration Program. Mente Park. Caltiomia (October).

State of Kunsas, Kansas Air Quatity Stottotes and Regufutionts, prepured by Kansas Department of Health and Environment. Bureatr of Air and Waste Managenent. Topeka.. Kansas, July (9))!.

State of Kansas. Kunsess Air Quelity Sumnury - 1989. prepared by Kansass Deparment of Health and Environment, Bureat of Air and Waste Managentent. Topeka. Kansas, IJy).

State of Oklahoma. I00n Okluhumu Air Qutity Retherr. prepared by Air Quality Service of the Oklahoma State Department of Health. Oklaktoma City. 1991.

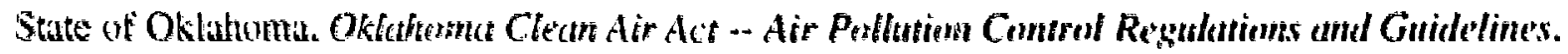
prepared by Air Quality Service. Ënvironmental Heath Services. Oklahoma State Department of Heateki. Oktationa City. 1981.

USBC (U.S. Bureat of the Census). 1987a. Census of Agriculture. Oklathmat State and Commty Data. Gergraphic Area Series. No. AC87-A-36. U.S. Depurtment of Commerce. Washington. D.C. 
USBC, 1987b, Census of Agriculture, Kansus State and County Data, Geographic Area Series, No. AC87-A-16. U.S. Departrnent of Commerce, Washington. D.C.

USEC, 1988, Caunty and City Data Burok, U.S. Department of Commerce, Washingon, D.C.

USBC, 1990b. Oklahoma: Summary Population and Howsing Charatteristics, 1990 Census an Population and Housing Reports Series. No. 1-38, U.S. Department of Cummeree. Washington, D.C.

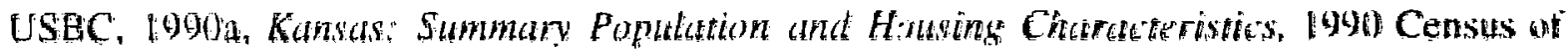
Population and Housing Reports Series. Non. 1-18. U.S. Depiatment of Commerce. Washingtont, D.C.

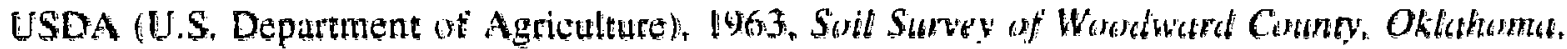
Soil Conservation Service, Washingen, D.C.

USDA. 1968, Soil Survey of Okmulgete Contnk, Okluhomb. Stril Conservation Service. Washingugon, D.C.

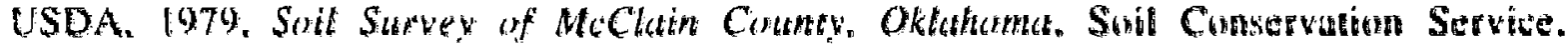
Wastington. D.C.

USDA, t980). Soil Survey of Montgumery County. Kansas. Soil Comservation Service. Washingron. D.C.

USDA. 1983, Sosil Survey of Marion Contme. Kathass. Stril Comservation Service. Washingtun. D.C.

USDA. 1985. Soil Strvey af Grant County, Oklahiomes. Soil Comservation Service. Washington, D.C.

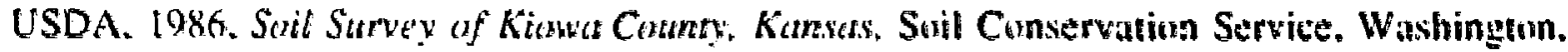
D.C.

Vik, D., 1991. Personal communication with A.J. Policastro, Argonne National Laburatory. Radian Electronics Services Center (RESC), Radian Curpuration. Austin. Texas (Detember 6).

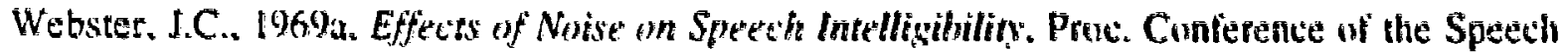
and Hearing Asserciation. Washingen. D.C. pp. 49.73. Feb.

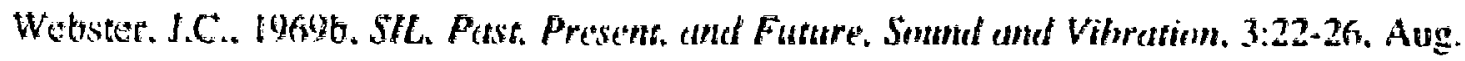




\section{Freparers}

This EA has been prepared by the Environmental Assessment and Intormation Sciences Division of Argenne National Laboratory. The Argonne staft members who contributed to the preparation of this. EA are listed below. Contributions are toted in brackets at the end of ejch entry.

- Larry Coke, M.S. Physigs, 17 years experience in mudeling dir and noise impacts [atised]

* Richard E. Liebich, B.E.E., Flectrict Engineer, P.E., 38 years experiente in

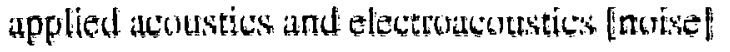

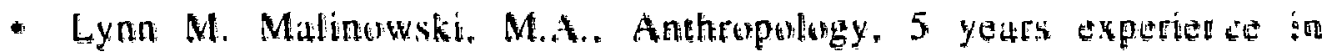
environmentul assessment [cultural resturces]

- Daniel Maloney. M.S. Mechanical Engintering. 4 years experiente in measurements and modeling air and noise impacts [novise!

- John M. Ptingston, M.A. M.P.A.. Environmental Adintnistration, 3 years experience in environmental assessment and land use planning lbiotic resources, land use. visuat resources, cultural resources, socioneconomics!

- Anthony J. Policastro. M.S. Ph.D. Civil Engineering. 21 years experience in modeling environmental transport precesses in air and water fnorise, air qualiy. water resources, soils

- Fred Wasmer. B.S.. Computer Science. 4 years expertente in measurements and modeling of air and noise impacts [nuise]

- Brenda L. Kuebnick. pursuing B.S. Computer Science. 3 years experience in Cid. graphics. destop publishing fcumputer graphies] 
6-2 


\section{Agencies, Organizations, and Otficials Contacted}

\subsection{Agencies, Organizations}

\section{Fadaral}

U.S. Army Corps of Engineers

U.S. Department of Agriculkure, Soil Cunservation Service

U.S. Department of Commerge, Bureatut the Centsis

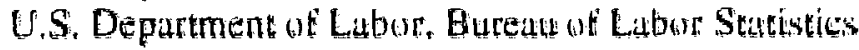

U. S. Fish and Wilulite Sorvice

\section{Stato}

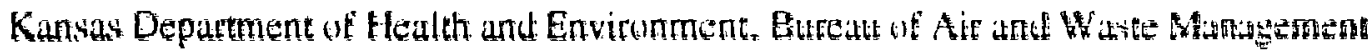

Kansas Departmente of Wildite and Parks.

Kansas Cienological Survey

Kansas State Board of Agriculture. Division ol Waler Reswurees

Kansas State Historical Suciety

Oklahoma Archeological Survey

Okkhoma Biological Survey.

Oklahoma Cooperative Extensiun Servico

Oktuhorna Uepatment of Wifdtie Cunservation

Qklahoma Ger " ugical Survay

Oktatuma State Artheologist

Oklahoma Sute Department of Health. Air Quality Service. Envitunntental Hewbh Services

Ok Iahoma State Historic Preservation Ottice

Oklahoma Water Resources Bourd

\section{County and Locat}

Clerk. City of Neodesha. Kintas:

Gartield Gounty Assessert. Oktahoma

Gartield County Commission. Oktahoma

Gartield Councy Metropotitan Area Plannog Commisstem Oklabuma

Gront Gunty Assessot. Oktuhuma

Gtant County District Conservationse. Okfahuma

Grant Councy Comtetission. Oklahome

Kiowa Couny District Conservationist. Kansas

Murton County Commtisionto Kansas

Marion County District Conservationist. Kansas

McClain County Commisston. Oklahoma 
McClain County District Conservationist. Oklahoma

Montgomery County Commission, Kansas.

Montgomery County District Conservationist, Kunsas

Okmulgee County Commission, Oklaftoma

Okmulgee County District Conservationist, Okluhumi

Woodward County District Conservationist, Oklahoma

\subsection{Otticials}

\section{oklahoma}

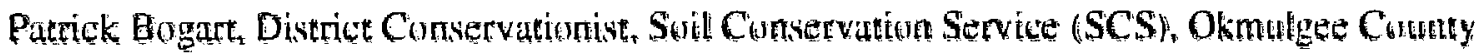

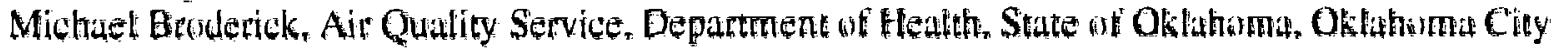
Robert L. Brooks, Oklahoma Aroheological Survey (OAS). Narman lan Butler. Oklatoma Hiological Survey. Nomnan

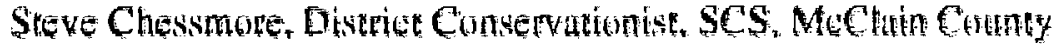
John Cruig, Water Quality Service. Stute of Okluhomit. Oklahome City:

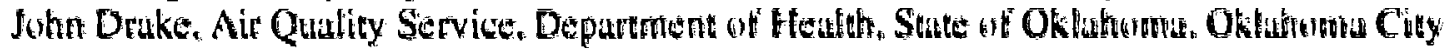
Roberk Fabian. Groundwater Div siqua Oktatrema Water Resturces Boud Stephen W. Forsythe. U.S. Fish de Wildhite Ssrvice (FWS). Tulisa Francie Getty. OAS, Norman Marshall Gettys, State Hitstoric Pręservation Oftice. ORfuhoma City

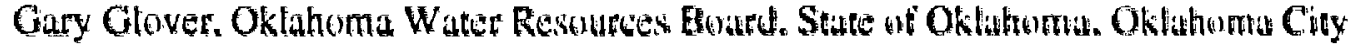
Kiurole Owerts. Fivs. Tulsa Scott Pade. Sull Conservationtiste SCS. Grant County Dwayne Rice. Soil Conservationist. SCS. Gurt tetul Cornty Bill Schultz, Grant County Assessur Charles M. Soutt. FWS. Tulsa

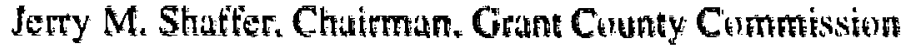
James Sheurhart. District Conservationist. SCS, Wogdward Corunty

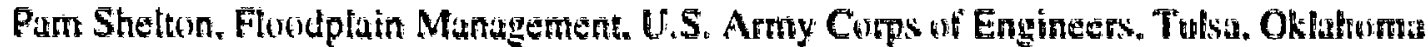
Earton Shirfey; Streamwater Division, Oklahoma Water Restences Buard. Oklahma City Bobby Smith. District Conservationtst. SCS. Gitunt County Scott Thomas, Air Quatity Service. Department of Health. State of Okluhoma. Okluhima City Bruce Underwood. Oklahoma Department of Wildhite Consertation. Oklahoma City Olin Unuh. Gartietd County Gomatsing

Guve Witcum. Supervisor. Grant County Jay Wond. Streamwater Divistem. Oklahoma Water Resources Bourd. Okluhnona City tan Yang. Okluhonta Water Resources Bourd. Oklahuma City 


\section{Kansas}

Dewey Castor, FWS, Manhanan

Shan Chen, Kansas Geological Survey. Tupeki.

Bruce FeIs, Chaiman, Montgomery County Commission

William H. Gill, FWS Manhatan

Mark Jansen. District Conservationist SCS. Ki wwa County

Rusself Laforee, Bureau of Water Protectica, Strte of Kansas, Tupeka

Tom McClain. Kansas Geological Survey. Topeka

Jan Meininger, Cily Clerk, Neodestat

Clarence Miller, District Conservationist. SCS. Mungamery Connty

Dan Mterhert. EWS, Manhatan

Richard Pankratz, Kansas State Historical Suctety. Topelét

Charles Penner. Planner, City ul Nebdestia

Euic Schenck Kansas Deparment of Widlite \& Puks, Fut

Gary Schuler. District Conservationist. SCS. Murwan County

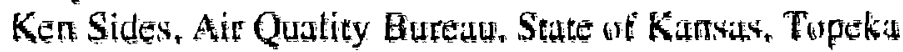

Matin Stein. Kansas State kistorieal Suctent. Tonekat

\section{Other}

Pat Laforte, Bureatu of Labor Statistics, Chicagor 
$7+4$ 
Appendix A

Landsat scenes Used tor Land Use Classiflcation 


\section{Appendix A}

\section{Landsat Scenes Used tor Land Use Classification}

This appendix includes the individuat 14 cloudless Landsat scenes that were classified tor tund use studies tor the Southern Great Plains Cloud and Radiation Testbed (CART) study area. The classes determined were crop, majority crop, mixed crop and rangeland, rangeland and brush. grassy, water, dry creek beds and urban, and wooded. Although the dates of the scenes span approximately two years $(1988-1989)$, they are all for tate summer or early fall. Dates of the scenes are include in the tigures. For the must part, the dominant trag in the area is winter wheith. Stenes have nut been tutally confirmed with ground truth but contidente is high ( $85 \%$ ). All 1 t\% scenes will be knited tor tiuture reterence. 


\section{LAND SATELLITE COORDINATES}

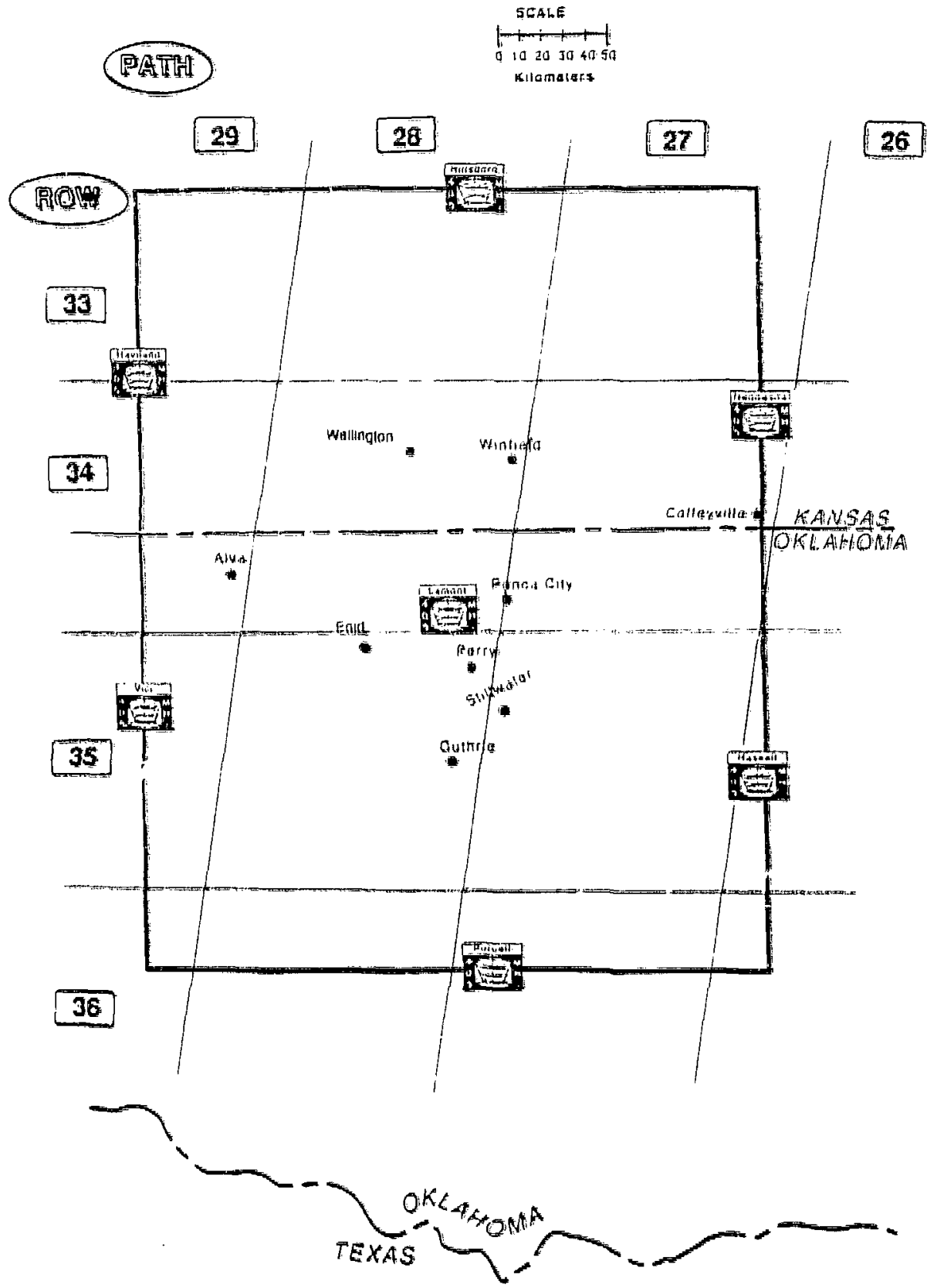

Figure A. I The path and row of the 14 Landsal scenes. Also included are the NOAA Wind Demonstration Network Profilers that can be used to identily approximate locations of the central tacility (Lamont, OK) and thig six boundary facilitios (Vici, Purcell, and Haskall, $O K$, and Neodesha. Hillstoro, and Haviland, KS). Select cilies are shown for further reference. 


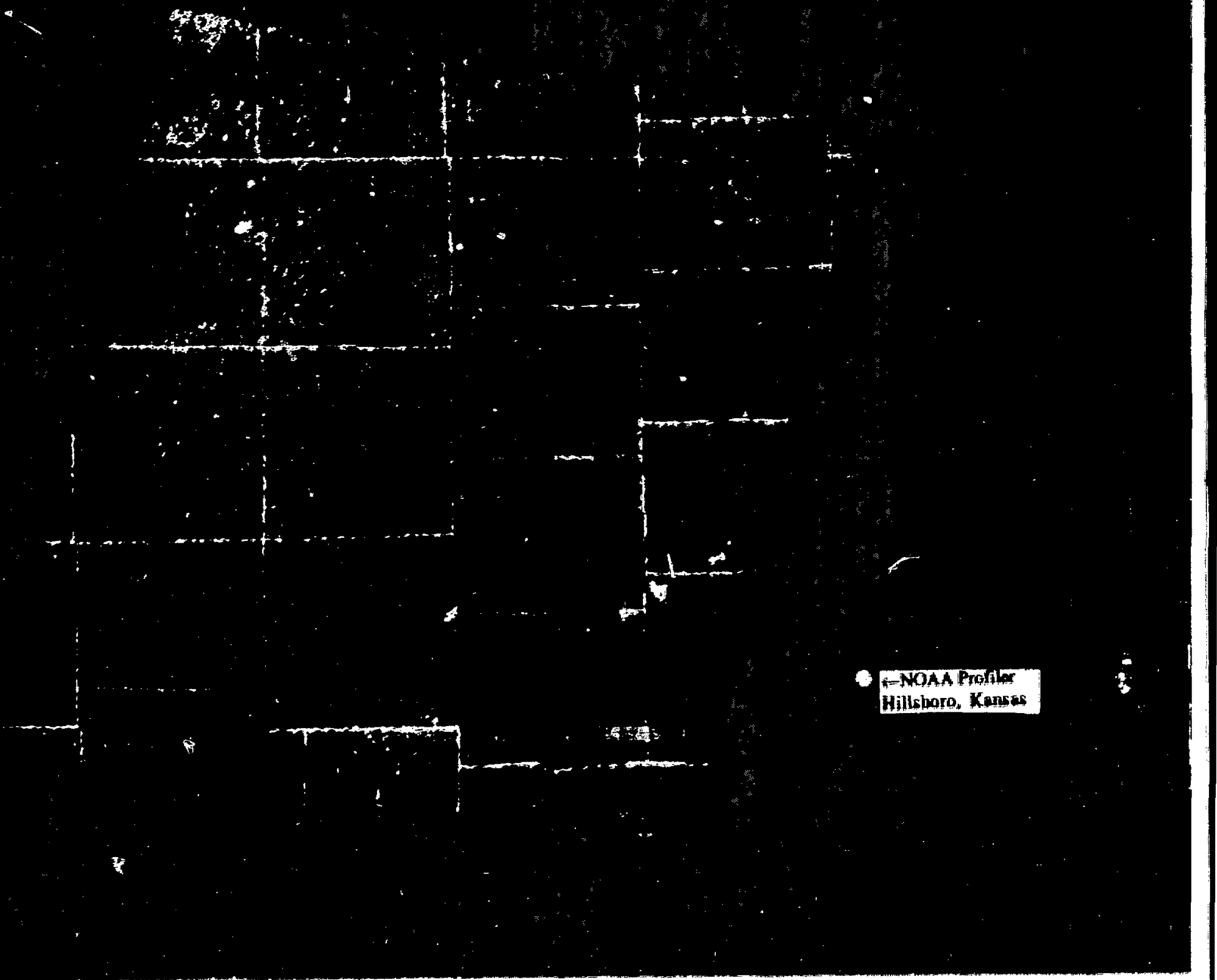

Figure A.2 Processed Land Satellite Data; Scene No. 1. Fath 29, Row 33, September 25, 1988. 


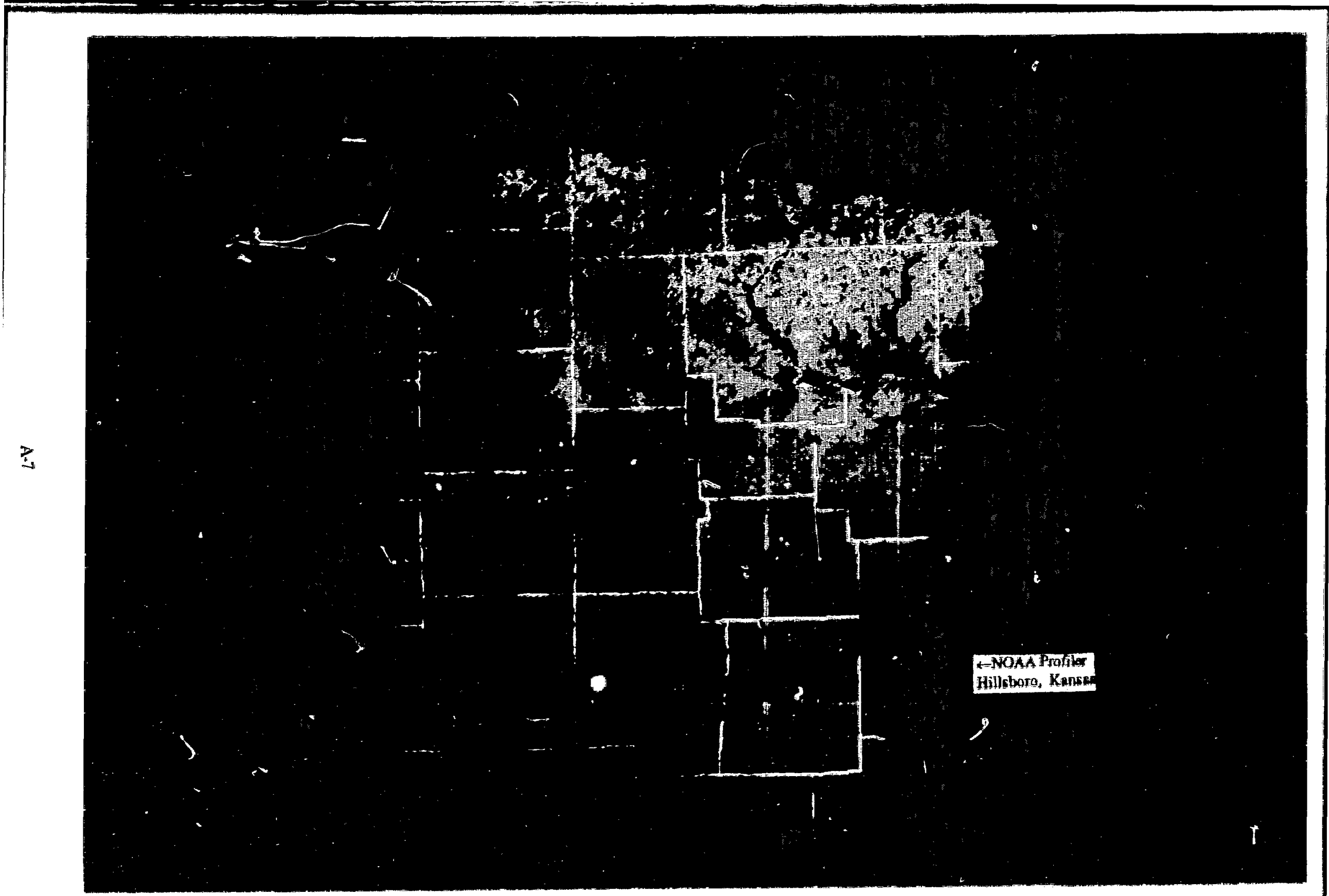




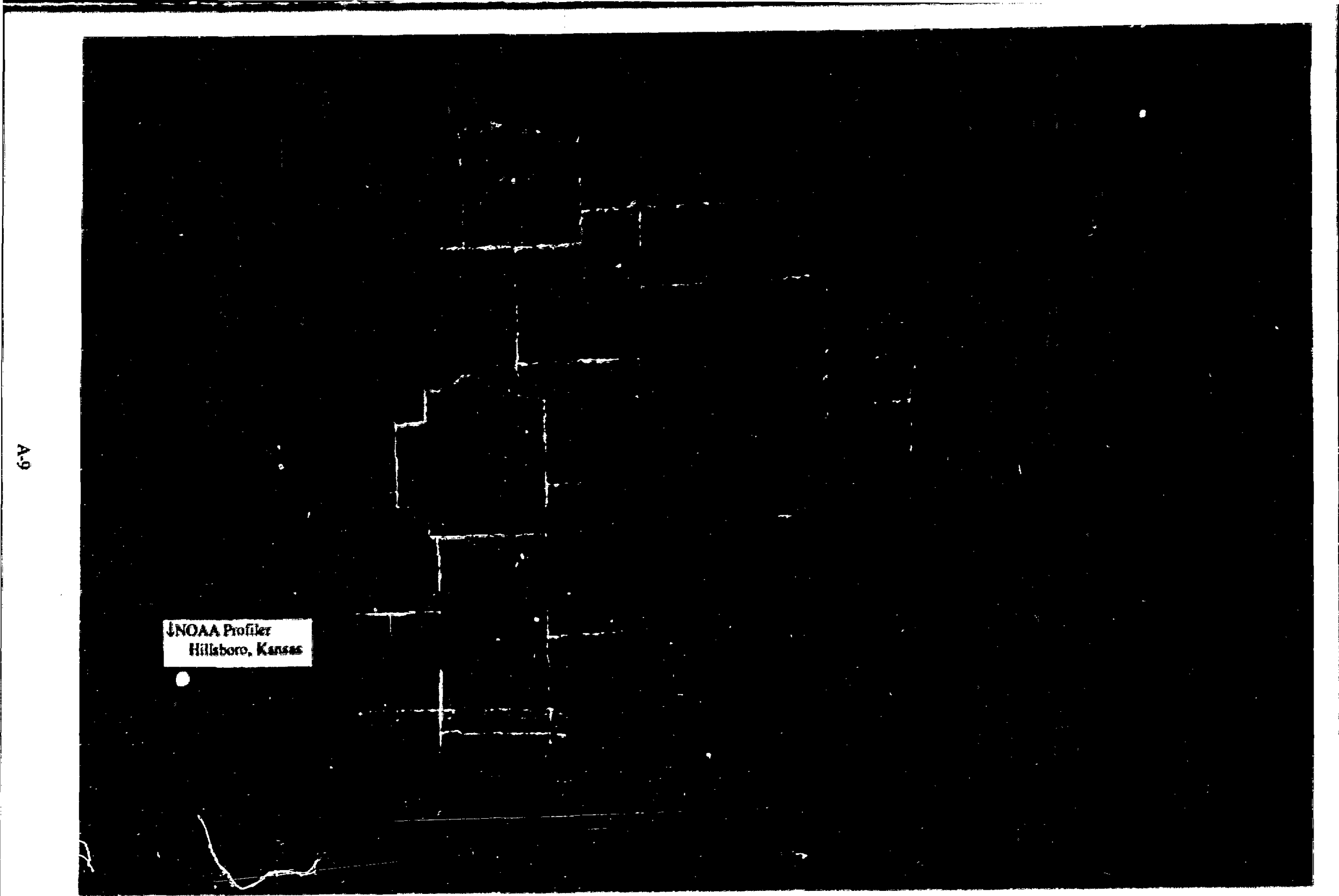

Figure A.4 Processed Land Sarellite Data; Scene No. 3, Path 27, Row 33; August 28, 1988. 


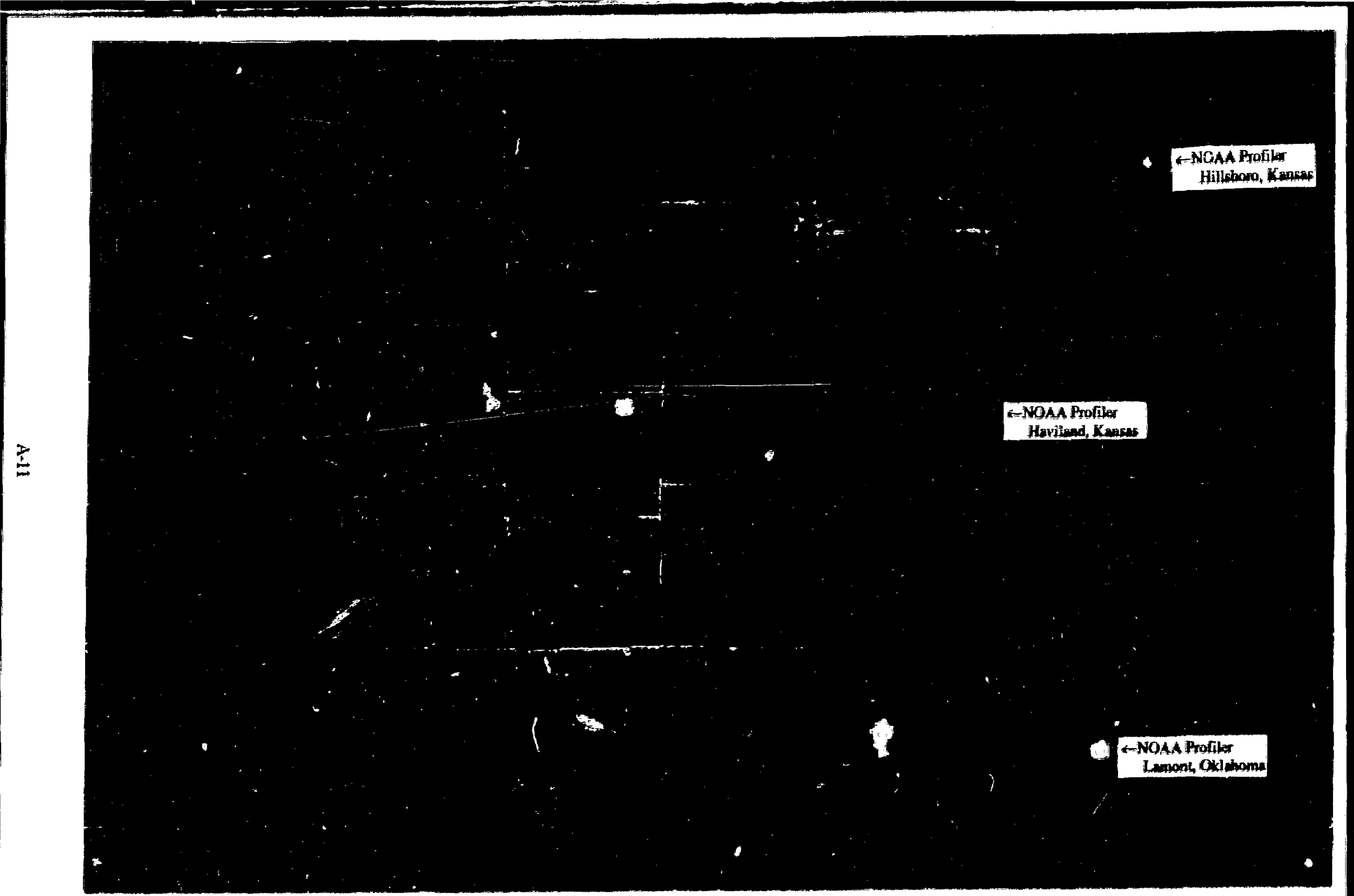

Figare A.5 Processed Land Sar Illite Data; Seene No. 4, Path 29, Row 34; September 9, 1988. 
$\checkmark$

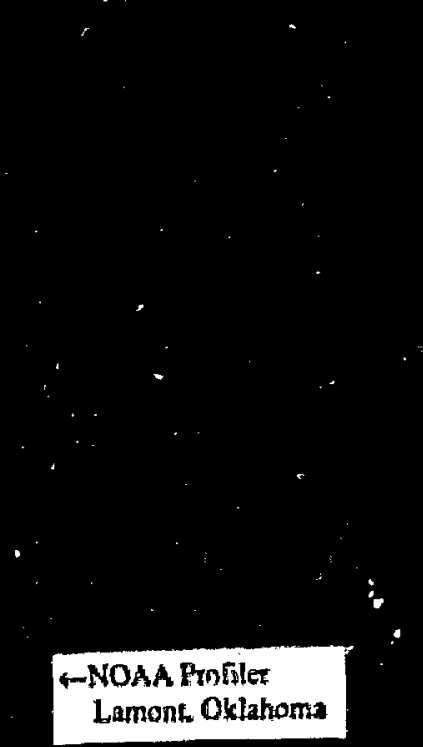

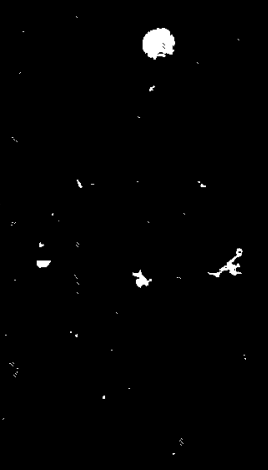

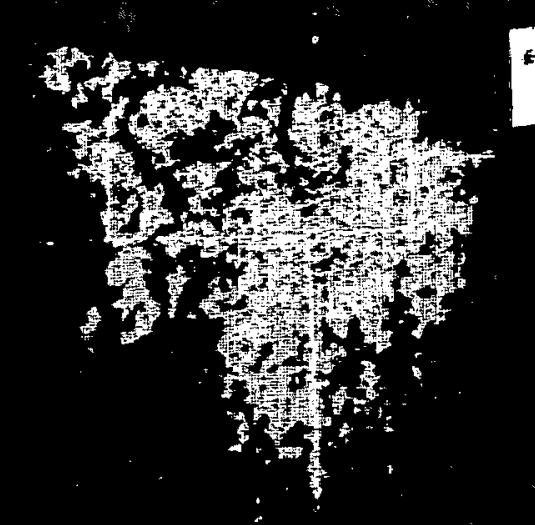
F-NOAA Profilet Hillsharo, Kansas

$\ldots$
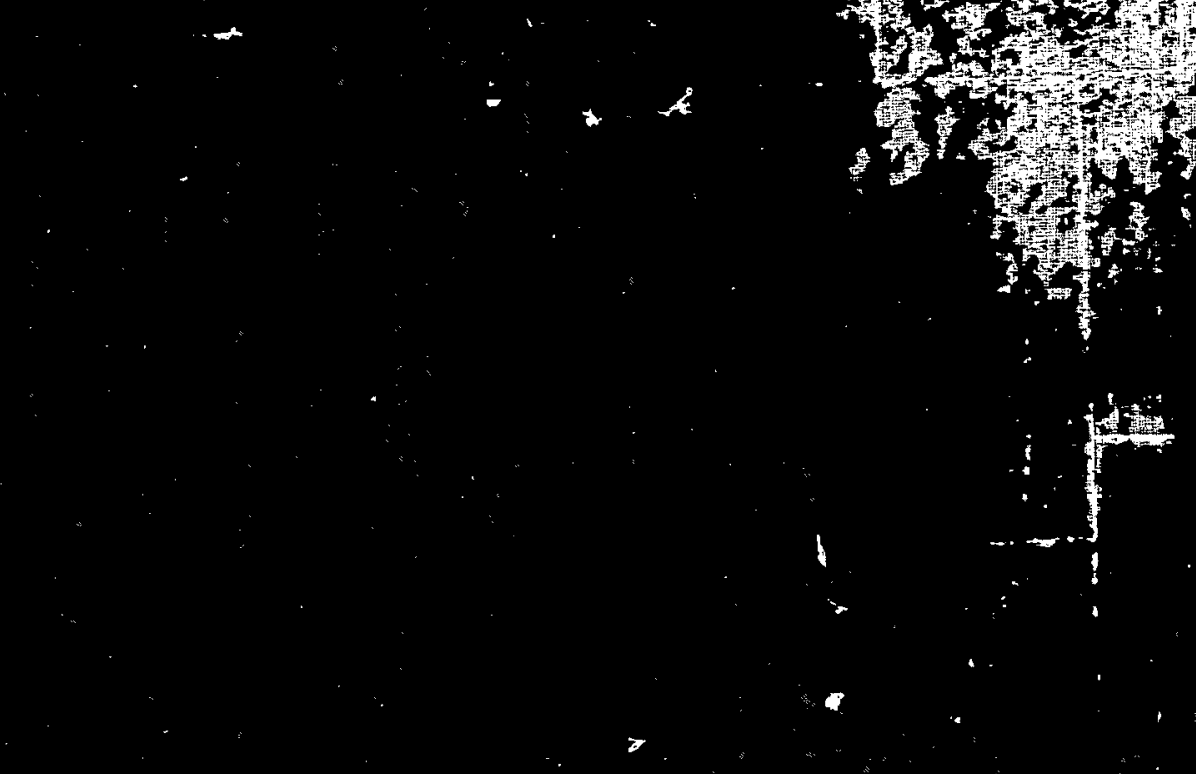

NOA PRofiler $\Rightarrow$

Neadeche, Kansas

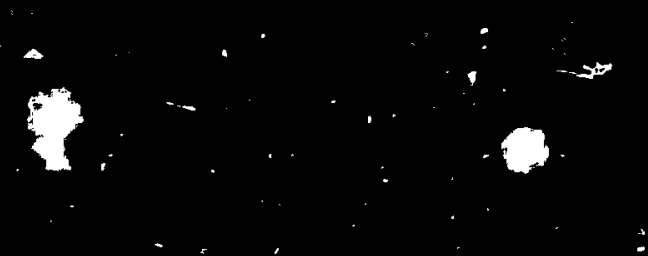

it

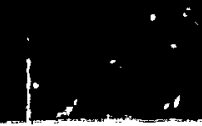




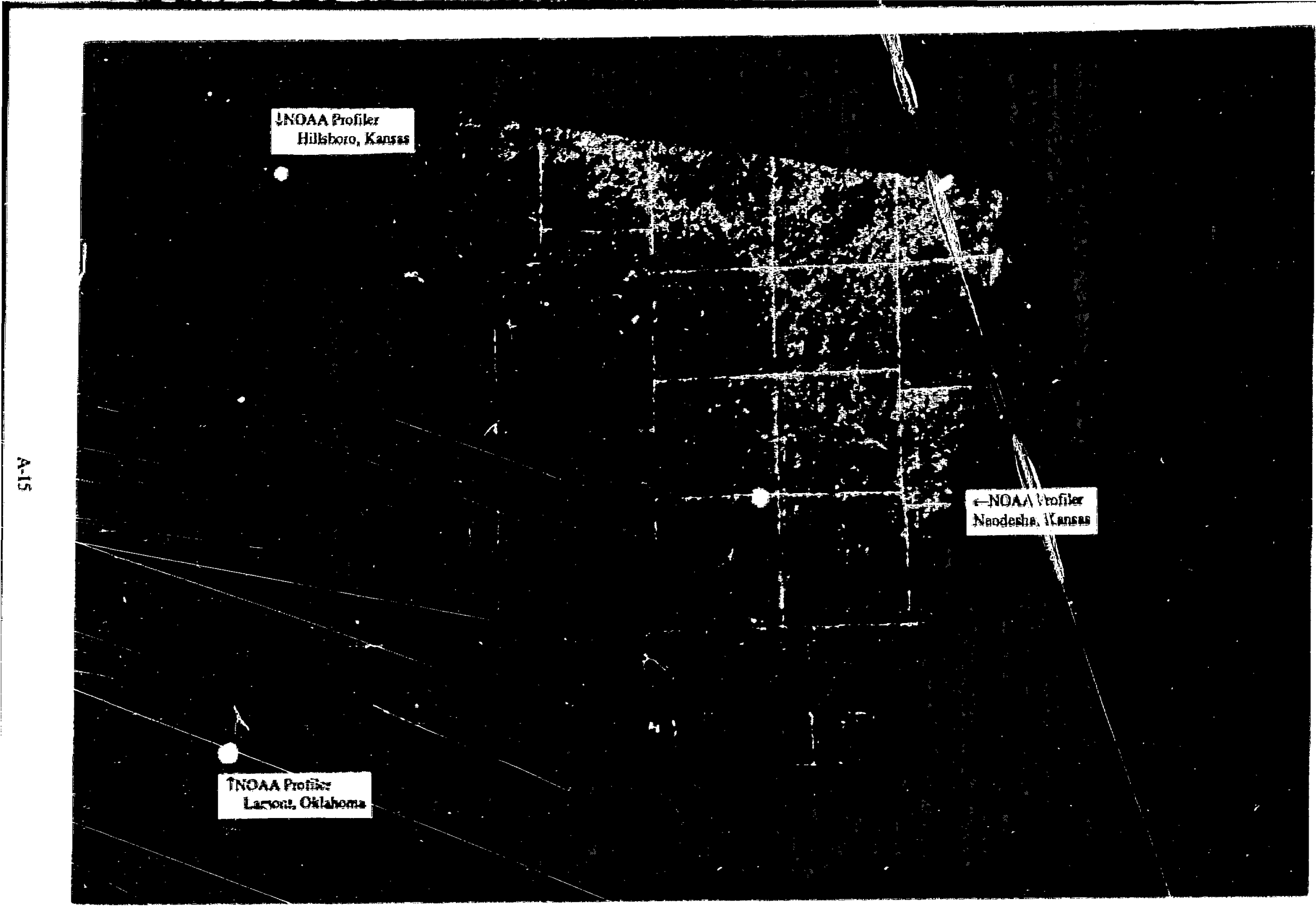

Figure A.7 


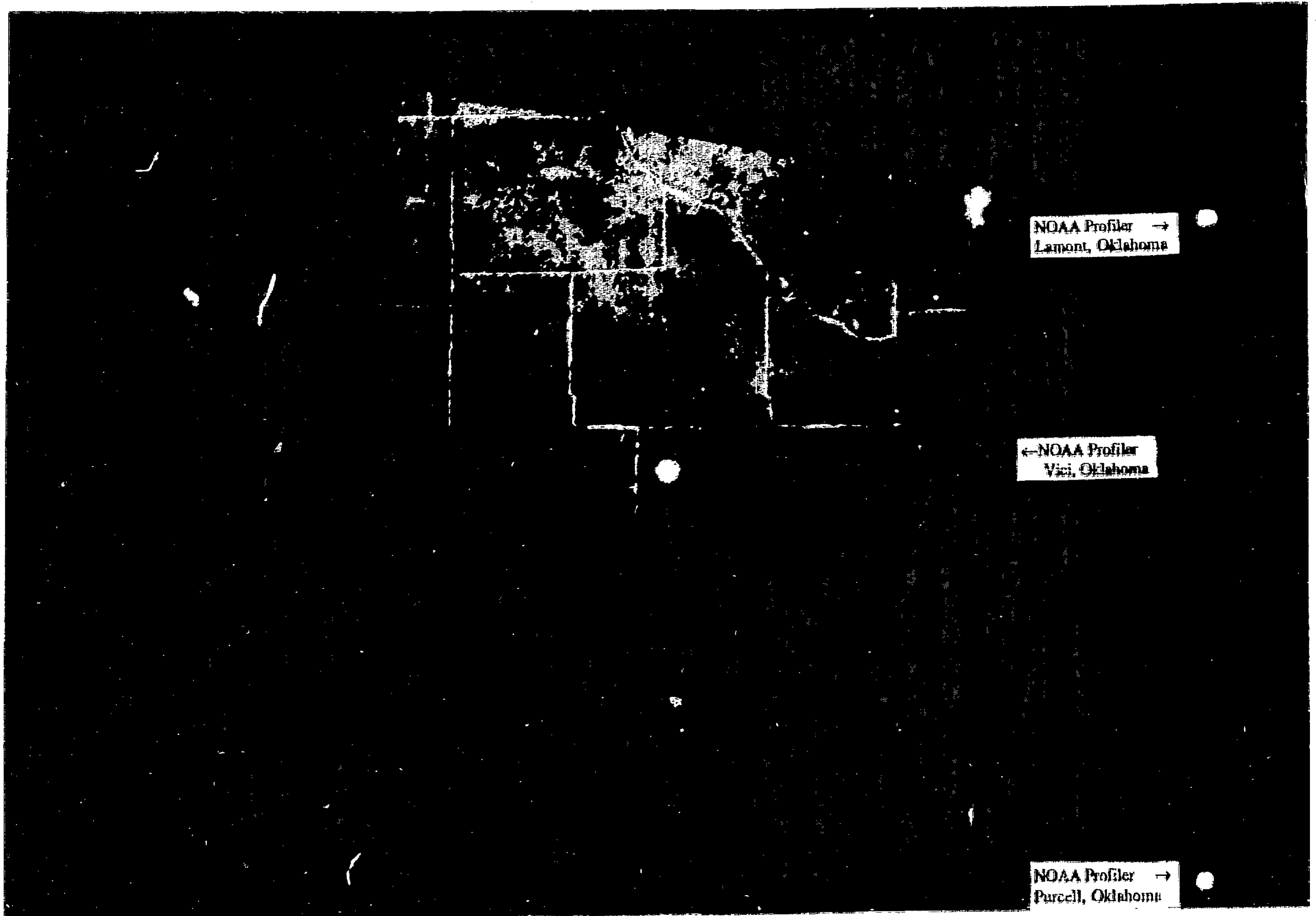




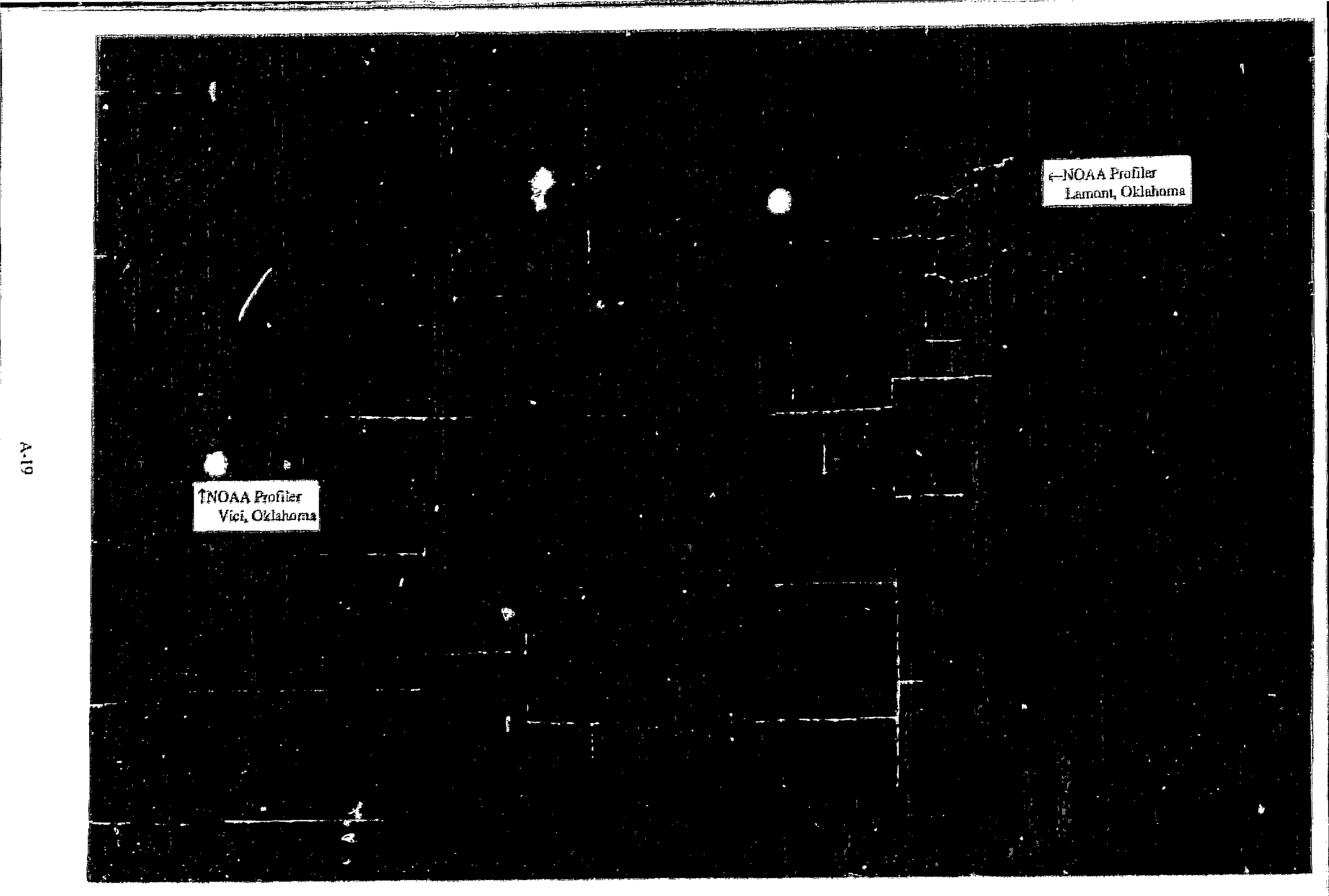

Figure A.9 Proeessed Land Sarellite Dara; Seene No. 8. Pain 2B. Row 35; September 29. 1989 
$+\because, 4$

ats,

1)

17x

17x

17x

(1)

thent

axis

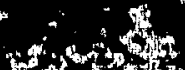

$-540+240$

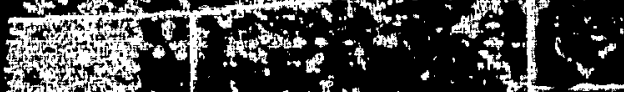

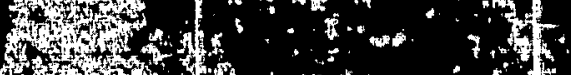

PIn

R

to $=-1$

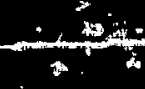

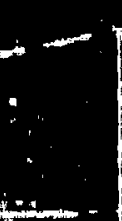

$y$ as

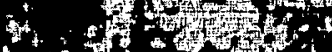
a. a , in

i. 2 to the

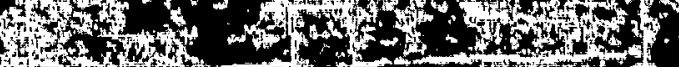

(3)
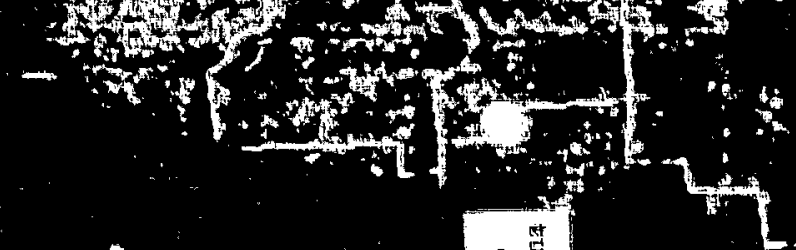

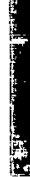

.

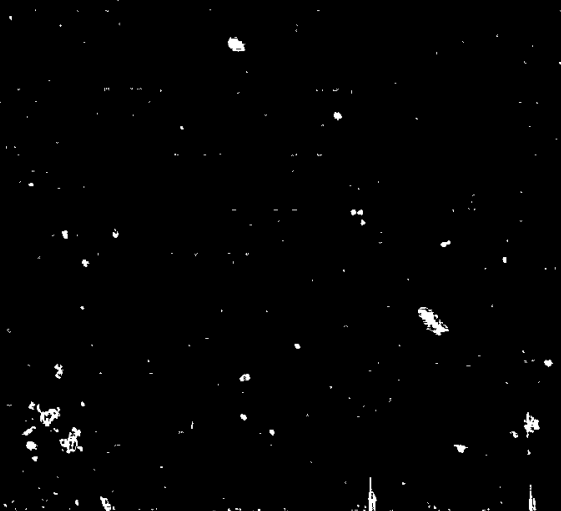




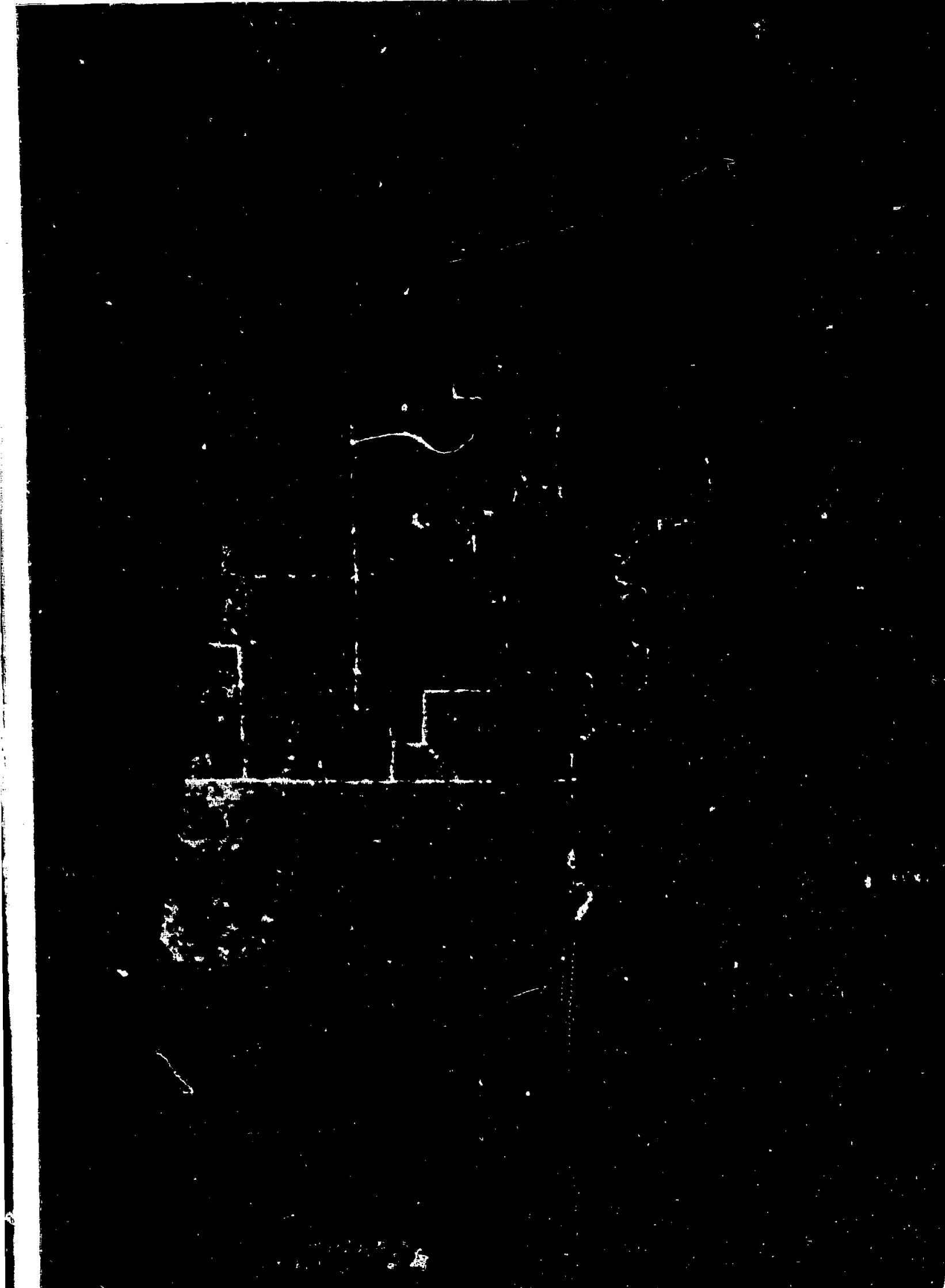




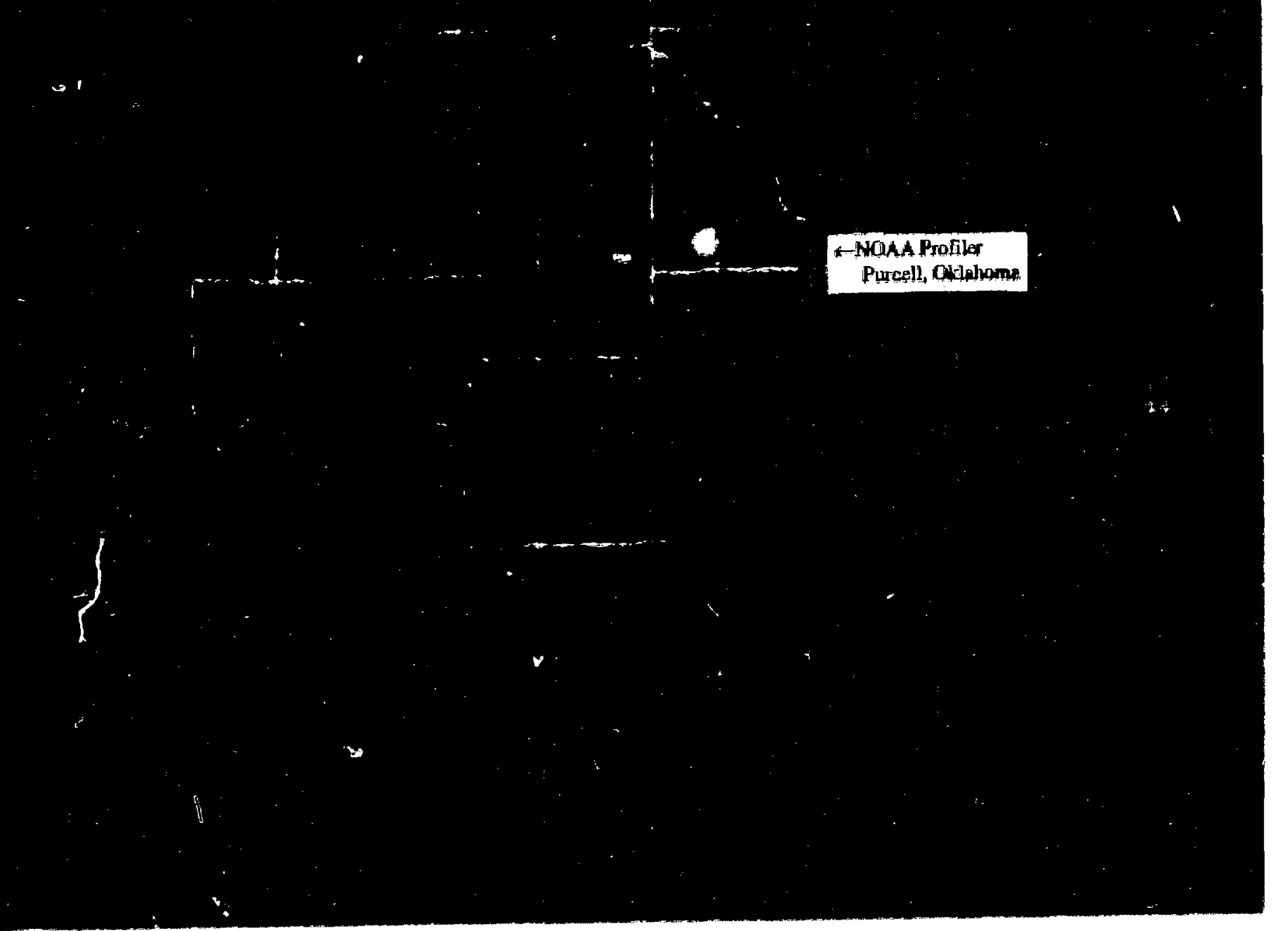




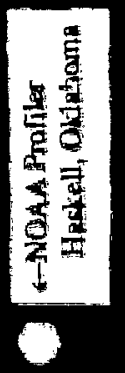

\section{3}

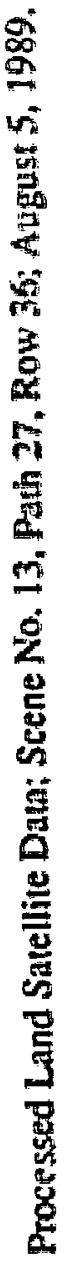

\pm
4
$\frac{5}{6}$ 

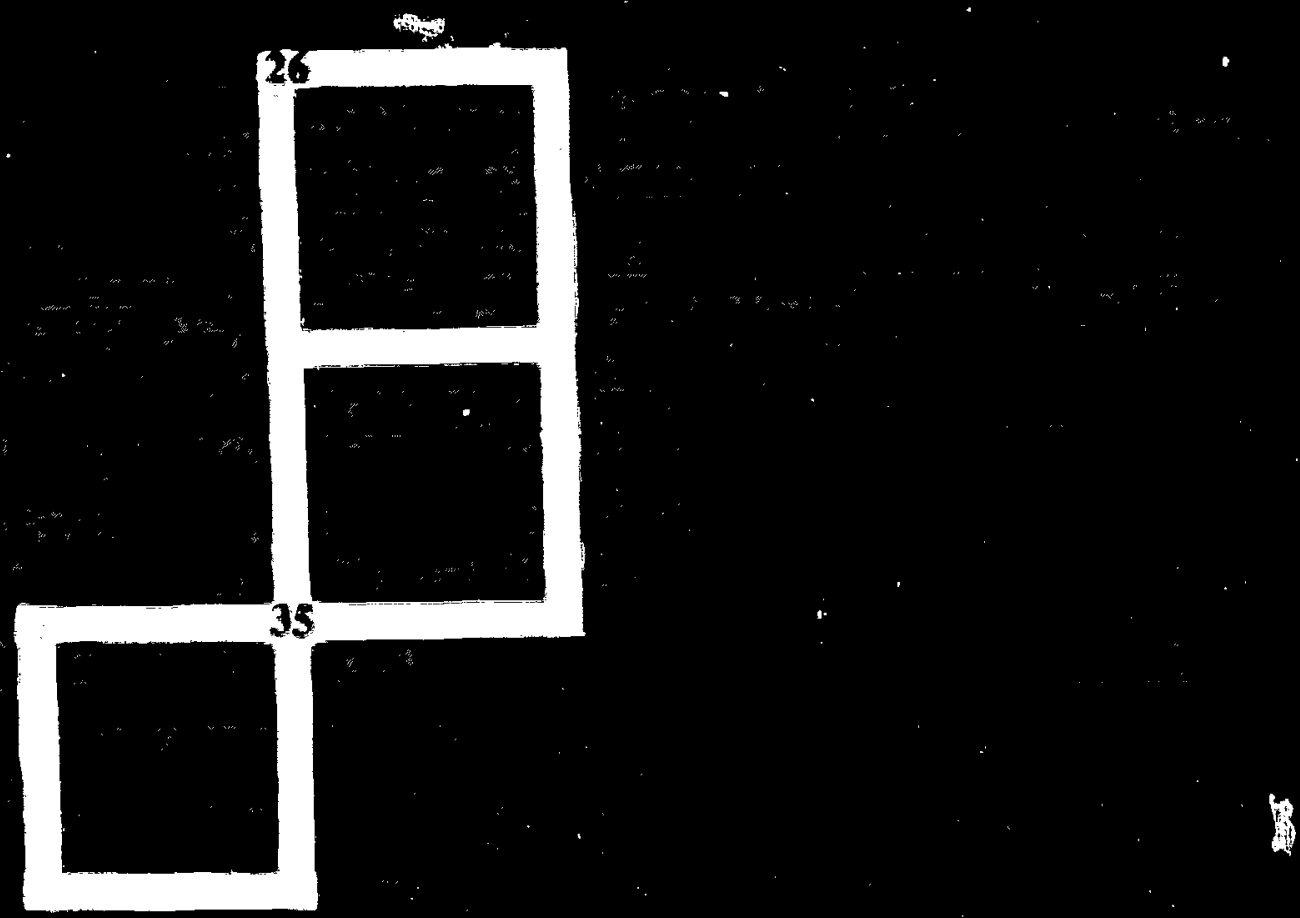

1

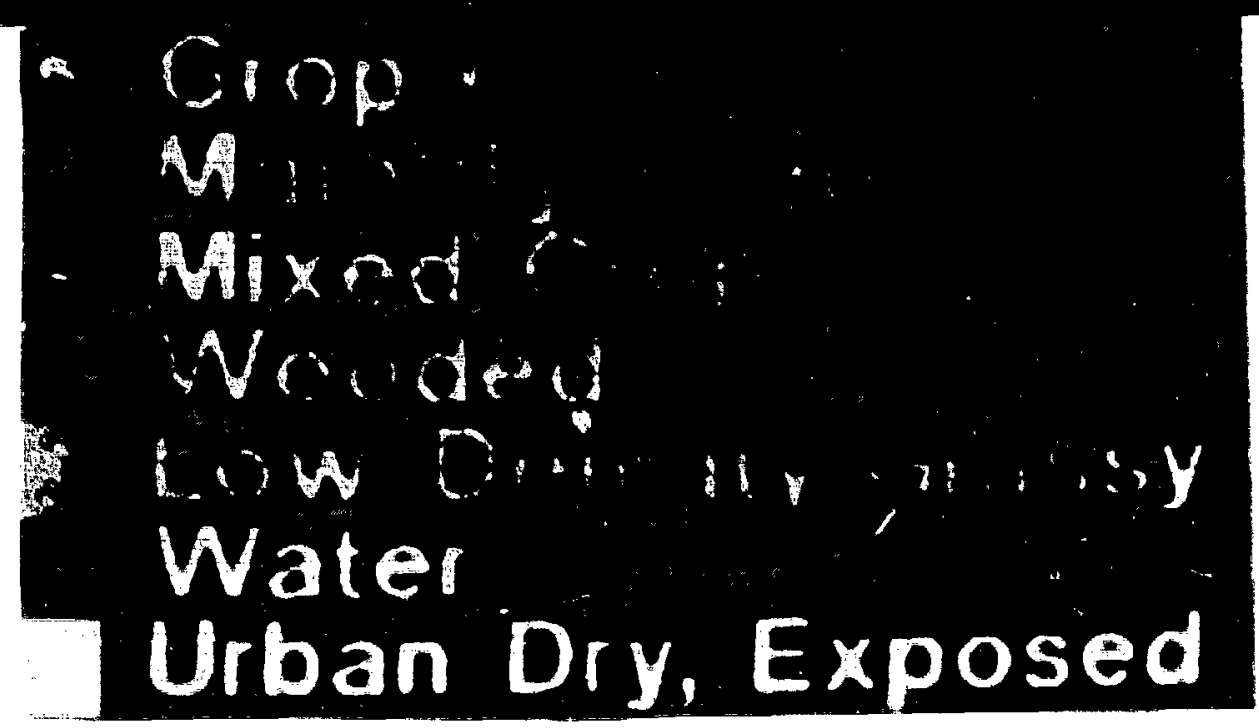

Figure $A^{\text {is }}$

Proposed location of the central facility and its two alternatives. First choice, Township 25 North, Range 3 West, Northwest 1/4 of Section 35: first altemative, Township 25 North, Range 3 West, Southeast 1/4 of Section 26: second alternative Township 25 North, Range 3 West, Southwest 1/4 of Section 35 . 


\section{Appondix $\mathbf{B}$}

Area of Surface Distutbance and Instrument Placement for Centrat, Boundary, Auxtllary, and Extended Sltes 
B-2 


\section{Appendix $\mathbf{B}$}

\section{Area of Surface Disturbance and Instrument Placement for Central, Boundary, Auxiliary, and Extended Sites}

The tables in this appendix provide information about the actual surfice disturbances and the space occupied by instrumentation, facilities, and fenced areas for the central, boundary. auxiliary, and extended facilities. The areas are given in square feet and acres. Totals are provided for individuat racilities and also for all facilities combined within the CART conceptual study area. A detailed description of the instruments and facilities (power requirements, anticipated delivery dates etc.) is also provided.

Table 日.1 Surlace Disturbances ak a Typrical Central Facility

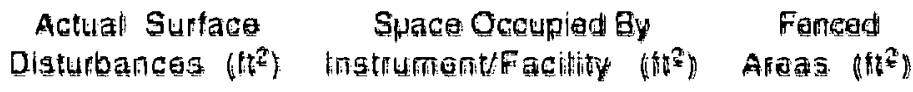

\section{Ist Area}

Microwave Padiometer

All-Sky Camera Shelter

Total Fence Aaquired for 1st Area

\section{2net Alog}

Facility $(7$ it $x$ 40 16) Housing: High-fitesolution Spoctrometer, and Calibration. and Coilomoter

\section{3rd Area}

Standard Metoorological

Moasurements Tower

Extonded Facitity

Broadband Radiometers

Plattorm

Spocialized Aadiation Stand

Suface Flux Station

Total Fonce Fequired tor Jue Area

$\Uparrow$ (4 base pads) 6

9

300

.20

280

$N / A^{b}$

9 (basa pads)

$$
\begin{array}{ll}
1(3 \text { anchors) } & 100 \text { \% } \\
14 \text { baso pads) } & 24
\end{array}
$$

( (3 base pads) 32

1 (4 baso pads) 24

5.625 
Tiable B.1 (continued)

Actual Surface Space Occupied By Fenced

Disturbances ( $\left.\mathrm{ft}^{2}\right)$ instrument/Facility $\left(\mathrm{ft}^{2}\right)$ Areas $\left(\mathrm{ft}^{2}\right)$

4th Area

Aarosol Observation Facility

(a) $x$ at $t$ (t)

gon Tawer

Tolal Fence Hequired for 4th Area

$50 \mathrm{Ap}$ A

$915-M H z$ RASS. \& Frallet

EOMHZ AASS \& POflE

AASS \& Frofiler

Equipment Facllity

(8) $x$ to t t )

Total Fence Required tor 5th Area

6L): Area

falvin lidger Trailen

$(7) \times 40+1)$

Saanning Radar Trailo:

(7) $x$ to 40 t)

Seanning Lidar Traila:

$(7 \mathrm{ft} \times 40 \mathrm{ft})$

\section{Ith Atea}

Ballogn Eanne Sounding System

Facility ( $\theta$ It $\times 12 \mathrm{H}$ )

Dock/Storago Facility

(consists of 15 it $x 30$ it slatago

aroa \& 5 it 30 it dock)

Olleg/taboratory Facilly

(totk $\times 60 t)$
90

1.6 (basa pads)

900

900

62,500

62.500

90

GO
46

90: (3) anchans) 45,250

900
90.๑00

320

320

320

132

96

600

600

650
$N / A^{b}$

N/A

N/A
280

N/A 
Table B.1 (continued)

Actual: Surface Space Occupied By Fancad

Disturbanges ( $\mathrm{tt}^{2} \mathrm{j}^{2}$ instrumant/Facility $\left(\mathrm{tt}^{2}\right)$ Areas $\left(\mathrm{ft}^{2}\right)$

Calibration Faciling

650

690

$(100 \mathrm{ft} \times 60 \mathrm{kt})$

Briveway/Parking Alea

12,000

$1: 2,000$

(inclugive of above tour items)

Tingal Fence Fequired for 7th Area

12,000

4 Facilly used to degignate either a mobiles home. Qn pantable building: The actual surface

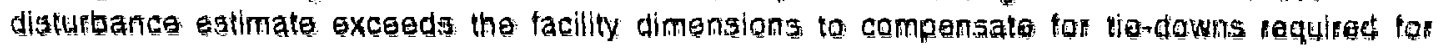

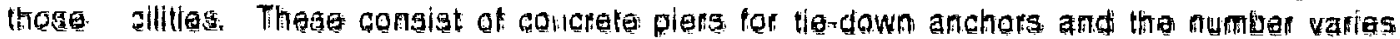
according to the gize of the trailer.

v. N/A $\#$ not applicable.

a beas altactive radiug of guy wirag.

* Pus altegtive radius of guy wires. 
Table B.2 Surface Disturbances at a Typical Boundary Facility

$\begin{array}{ccc}\text { Actual Surface } & \text { Space Occupied By } & \text { Fenced } \\ \text { Disturbances }\left(\mathrm{ft}^{2}\right) & \text { Instrument/Facility }\left(\mathrm{ft}^{2}\right) & \text { Areas }\left(\mathrm{ft}^{2}\right)\end{array}$

\section{5t Areg}

Facllity $(7 \mathrm{ft} \times 40 \mathrm{ft})$ Housing:

High Resolution Spectromater.

and Calbration and Ofice Area

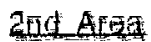

Standard Matogrological

Measurements Tower

Extended Facillty

Eroadband Fadiomelers

Plattorm

Surface Fiux \$tation

Total Fence Required for and Area

\section{3rd Area}

915. MHZ FASS \& Profilar

50 MHz AASS \& Profller

AASS \& Proflior

Equipment Facility

(8) $\times 10 t$ t)

Tolal Fonce Required tor Jrd Area

\section{4h Area}

Balloon Borne Sounding System

Facility $(8 \mathrm{ft} \times 12 \mathrm{tt})$

Dockstorago Facility

(to ft $x$ 10 ft storago aroa

\& it $\times 10$ th dock)

Divoway/Papking Area

(inclusive of above 2 llomst

Total Fence Fequired for 4th Area
320

280

N/A

9 (base pads)

n

1 (3 anchors) good

(4 base pads)

24

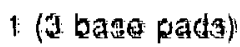

32

5,625

900

900

62, 500

62.500

90

00

132

96

150

150

2.800

2.800
90.900

2.800 
Táble B.2 (continued)

a Facility used to designate enther a mobile tome, of portable ouilding. The actuall surface disturbance estimate exceeds the facility dimensions to compensate tor tie-downs required for those facilities. These consist of concrete plers for tiendown anchors and the number varies ancording to the size of the trailer.

b $\mathrm{N} / \mathrm{A}=$ not applicablo.

c Less eftective radius of guy wires.

* Plus affective radius of guy wires. 
Table 6.3 Surface Disturbances at a Typical Auxiliany Facility

Actual Suntace Space Occupied By Fenced

Disturbances (fta) instrument/Facifity $\left(t^{2} t^{2}\right)$ Areas $\left(\mathrm{tt}^{2}\right)$

\begin{tabular}{|c|c|}
\hline All:Sky Camera Shelter & 9 \\
\hline $\begin{array}{l}\text { Standard Wetaoralogical } \\
\text { Measurements Towat }\end{array}$ & 9 (base pad) \\
\hline $\begin{array}{l}\text { Extended Facilly } \\
\text { Groadband Fadionetors } \\
\text { Platform }\end{array}$ & \\
\hline $\begin{array}{l}\text { Surface Flux Station } \\
\text { Fotal Fenced Fequired for Area }\end{array}$ & 1 (3 basto pads) \\
\hline 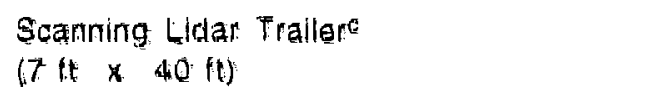 & 320 \\
\hline $\begin{array}{l}\text { Less affective radius of quy wires. } \\
\text { Plus affective radius of guy wires. } \\
\text { a One of the six auxilian tacilities may. } \\
\text { b. N/A a not applicable. }\end{array}$ & have scanning lidar. \\
\hline
\end{tabular}

$\theta$

19

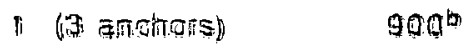

14 base pads) 24

10.900

$2 B 0$

Tables 8.4 Surface Disturbances at a Typical Extondod Facility

\begin{tabular}{|c|c|c|}
\hline & 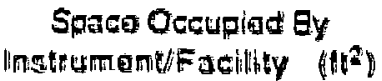 & $\begin{array}{l}\text { Fonced } \\
\text { Aroas (nto }\end{array}$ \\
\hline
\end{tabular}

\begin{tabular}{|c|c|c|c|}
\hline $\begin{array}{l}\text { Standard Meteorolagical } \\
\text { Measurements Tower }\end{array}$ & 9 (basa pad) & $\Uparrow(3$ anchors) & $900^{5}$ \\
\hline $\begin{array}{l}\text { Extandad Facility } \\
\text { Bruadband: Fadiomators } \\
\text { Trattopr. }\end{array}$ & & 14 baso padsi & 24 \\
\hline Surtace Flux Station & 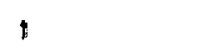 & 32 & \\
\hline Total Fence Required for Area & & & 5.625 \\
\hline
\end{tabular}

* Less elfective radius of guy wiras.

- Slus atfuctivo radius of guy wires. 
Table B.5 Total Surface Disturbances by All Facility Types and Total Sur.ace Disturbances to the CART Study Area ${ }^{a}$

\begin{tabular}{|c|c|c|c|}
\hline & $\begin{array}{l}\text { Actual: Sunfaco } \\
\text { Disturbances } \\
\text { [ft: (acres) }\end{array}$ & $\begin{array}{c}\text { Space occupied By } \\
\text { InstrumenuFacility } \\
\text { [(t) (acres)] }\end{array}$ & $\begin{array}{c}\text { Fenced } \\
\text { Areas } \\
{\left[\mathrm{ftg}^{2} \text { (acres) }\right.}\end{array}$ \\
\hline Contral Facillty & $\begin{array}{r}79,027 \\
(1,83)\end{array}$ & $\begin{array}{c}124,926 \\
(2,89)\end{array}$ & $\begin{array}{c}108,825 \\
(2.52)\end{array}$ \\
\hline Boundary Facility & $\begin{array}{c}60.602 \\
(1.55)\end{array}$ & $\begin{array}{r}67,747 \\
(11.57)\end{array}$ & $\begin{array}{l}99.425 \\
(2.29)\end{array}$ \\
\hline Auxiliary Facility & 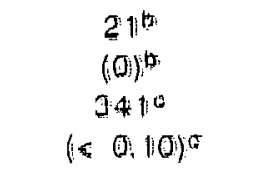 & 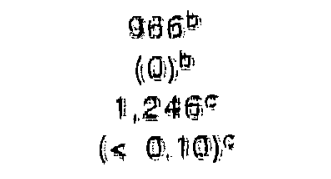 & $\begin{array}{l}3,000 \\
(0,23)\end{array}$ \\
\hline Extended: Facility & $1 \leqslant 0.104$ & $\begin{array}{c}557 \\
(+0)\end{array}$ & $\begin{array}{l}5,0,5 \\
60103\end{array}$ \\
\hline \multicolumn{4}{|l|}{ CAFT SITE } \\
\hline One Gentral Facillty & $\begin{array}{l}79,027 \\
(1,01)\end{array}$ & $\begin{array}{l}124.926 \\
(2.99)\end{array}$ & $\begin{array}{c}109,825 \\
(2,52))\end{array}$ \\
\hline Six Boundary Facilitiea & $\begin{array}{l}4011.172 \\
(0.27)\end{array}$ & $\begin{array}{c}406,402 \\
(9.39)\end{array}$ & $\begin{array}{l}590,550 \\
(1,3,65)\end{array}$ \\
\hline Six Auxiliary facilltios & $\begin{array}{c}156^{5} \\
(<0.10)^{6} \\
446, \\
(40,10)^{6}\end{array}$ & $\begin{array}{l}5,706 \\
(0,13)^{6} \\
6,076 \\
(<0,10)\end{array}$ & $\begin{array}{l}00.000 \\
(1.99)\end{array}$ \\
\hline $\begin{array}{l}\text { Twanty-live Extondad } \\
\text { Facilities }\end{array}$ & $\begin{array}{c}300 \\
(40.10)\end{array}$ & $\begin{array}{l}25,925 \\
(<0.55)\end{array}$ & $\begin{array}{c}140,6.5) \\
(3.25)\end{array}$ \\
\hline $\begin{array}{l}\text { Total Without } \\
\text { Scanning Lidar }\end{array}$ & $\begin{array}{l}480,625^{5} \\
(11,1 \pi)^{6}\end{array}$ & $\begin{array}{l}56+, 129 q^{4} \\
(1+2.97)^{4}\end{array}$ & $\begin{array}{l}\text { T00.000) } \\
(20.001)\end{array}$ \\
\hline $\begin{array}{l}\text { Tokal with } \\
\text { Scanning Lidar }\end{array}$ & $\begin{array}{l}480,9455^{2} \\
(11.111)^{6}\end{array}$ & 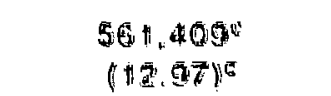 & \\
\hline
\end{tabular}

\footnotetext{
* All totals are $\mathrm{a} 10 \%$

b. Without sogneing lidar.

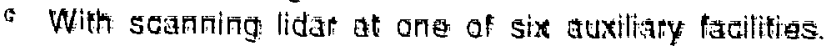


Table B.6 Instmument Slatus for Soumern Great Plans

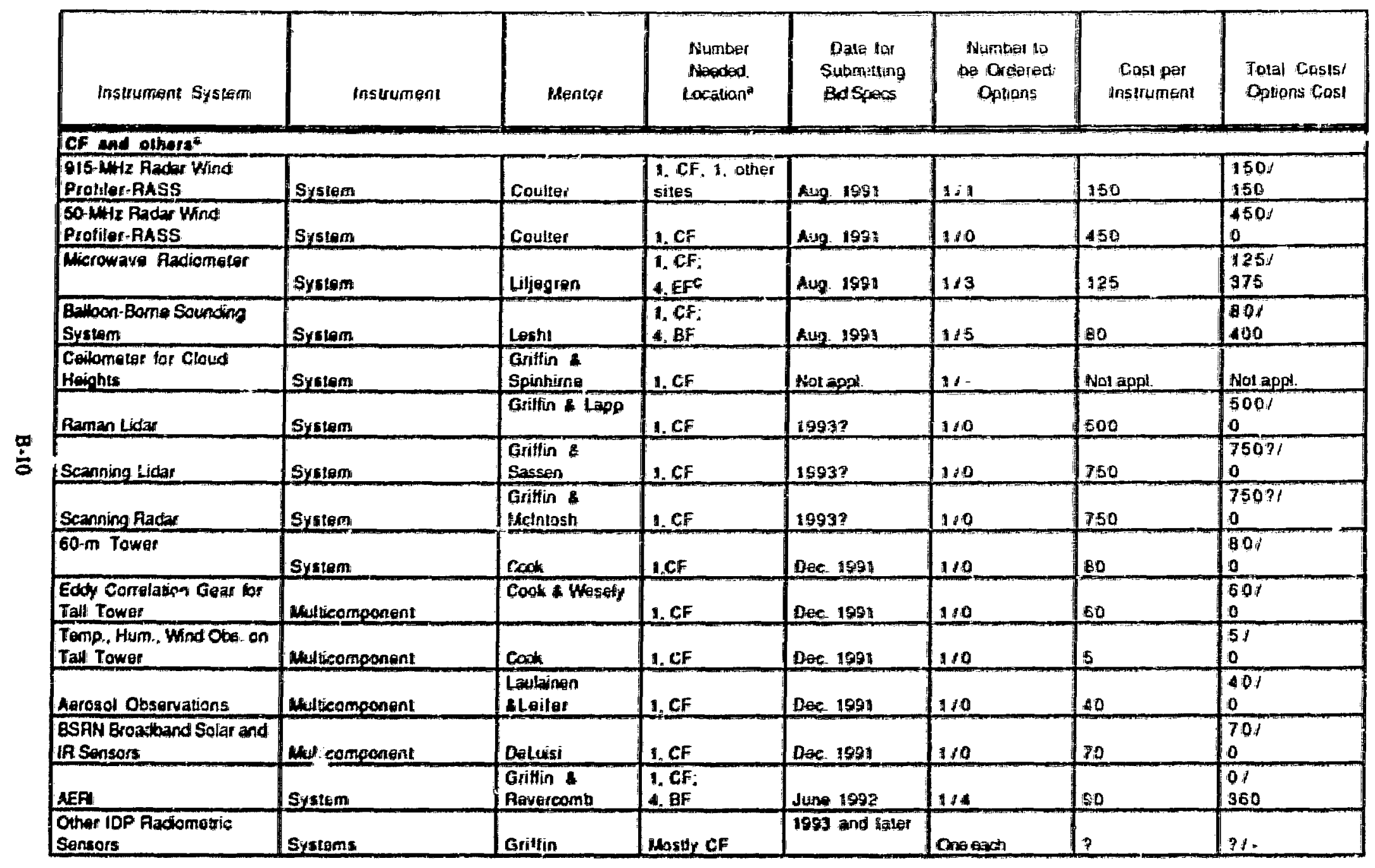


Table B.6. (continueo)

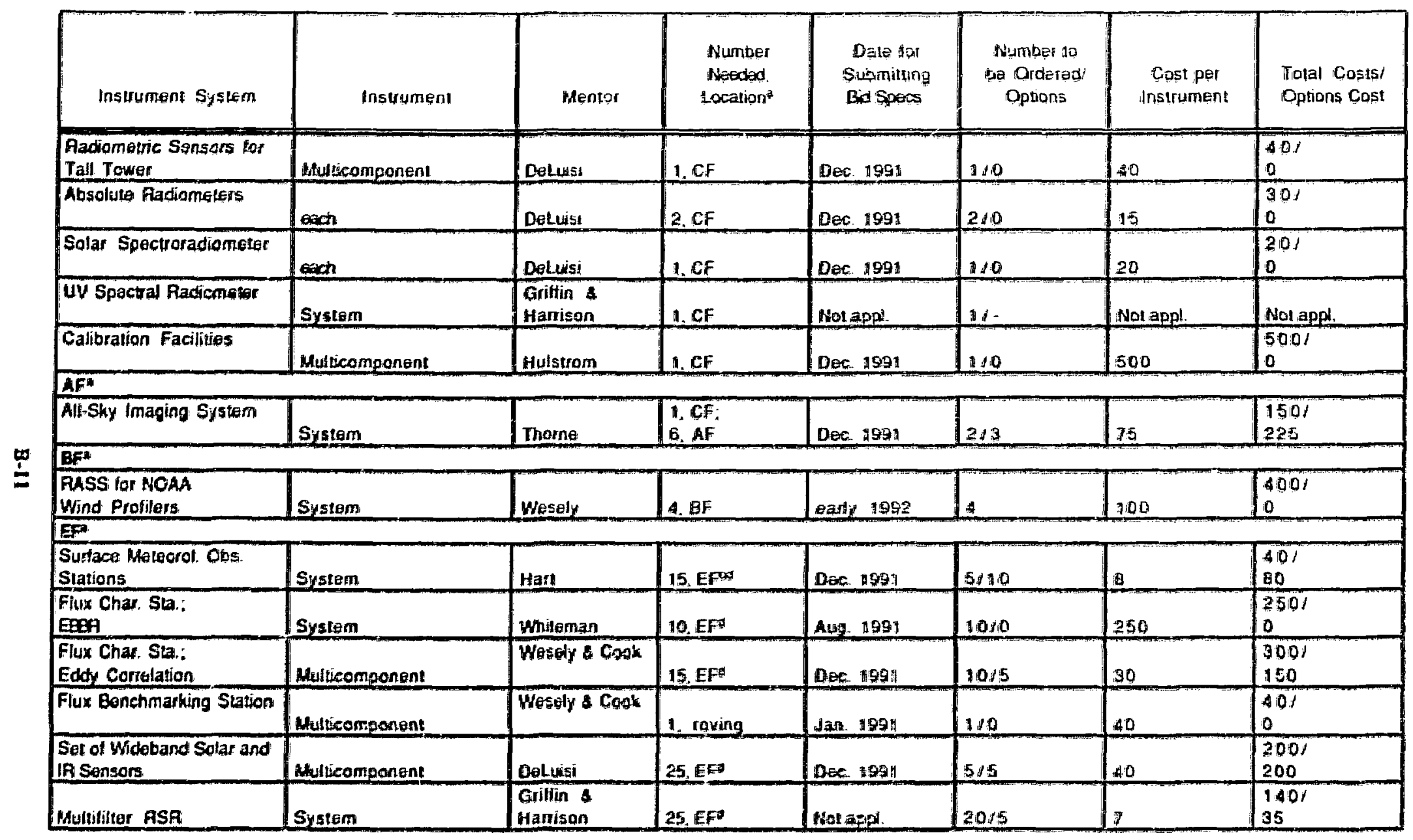


Table 8.6. (continuad)

\begin{tabular}{|c|c|c|c|c|c|c|}
\hline Instrument System & $\begin{array}{c}\text { Delivery } \\
\text { DaterOptions }\end{array}$ & $\begin{array}{l}\text { Additional } \\
\text { Procusemenls }\end{array}$ & $\begin{array}{c}\text { Nent } \\
\text { Anstallation } \\
\text { WhenWhese }\end{array}$ & $\begin{array}{l}\text { Sluaclities } \\
\text { Unadod }\end{array}$ & $\begin{array}{l}\text { Power } \\
\text { Naedad }\end{array}$ & Comments \\
\hline \multicolumn{7}{|l|}{ CF and athere ${ }^{7}$} \\
\hline $\begin{array}{l}\text { 915-MHiz Radar Wind } \\
\text { Protilor-PASS }\end{array}$ & \begin{tabular}{|l} 
Apr. 15924 \\
Dee. ig92 \\
\end{tabular} & Hiona tor SGP & $\begin{array}{l}\text { Ag. } 19921 \\
\text { 1. CF }\end{array}$ & $\begin{array}{l}50 \mathrm{ft}^{2} \text { in } \\
\text { shellex }\end{array}$ & $0.5 \mathrm{kVA}, \mathrm{AC}$ if & Second unit would ba a finater. \\
\hline $\begin{array}{l}\text { 50-MHE Radar Wind } \\
\text { Profiler-AMSS } \\
\end{array}$ & $\begin{array}{l}\text { Junt } \\
0 \\
0\end{array}$ & None tor SGP & $\begin{array}{l}\text { sune } 19921 \\
\text { 1.CF }\end{array}$ & $\begin{array}{l}50 \mathrm{ft}^{2} \text { in } \\
\text { shellex }\end{array}$ & $\begin{array}{l}2 \mathrm{kVA} \text { aY. AC } \\
11 .\end{array}$ & $\begin{array}{l}\text { Daijuary date known only to } \\
\text { within } 2 \text { months. }\end{array}$ \\
\hline Microwave Radionglor & $\begin{array}{l}\text { Apr. } 19921 \\
\text { Roc. } 1902\end{array}$ & $\begin{array}{l}\text { Naybe two more } \\
\text { for SGP }\end{array}$ & $\begin{array}{l}\text { Afr- } 15921 \\
\text { 1. CF }\end{array}$ & Nona & O.1 KWA, AC II & $\begin{array}{l}\text { Delivary data not known for } \\
\text { certain. }\end{array}$ \\
\hline $\begin{array}{l}\text { Ealloon-Bome Sounding } \\
\text { Syatem }\end{array}$ & $\begin{array}{l}\text { Apr. } 10921 \\
\text { Dec. } 1992\end{array}$ & Nona tor SGP & $\begin{array}{l}\text { Apr. } 10921 \\
\text { 1. CF }\end{array}$ & $\begin{array}{l}\text { Shaller } \\
\text { provided }\end{array}$ & $\begin{array}{l}0.3 \text { hVA, AC } 11 . \\
\text { when DP. }\end{array}$ & $\begin{array}{l}\text { Four additional units tor EFs in } \\
1992\end{array}$ \\
\hline $\begin{array}{l}\text { Coilometer for clavd } \\
\text { Hoights }\end{array}$ & $\begin{array}{l}\text { Somplime in } \\
1992\end{array}$ & Hona tor SGP & $\begin{array}{l}\text { Perthaps Apr } \\
1992\end{array}$ & $\begin{array}{l}\text { Sholler with } \\
\text { wincow }\end{array}$ & $6 \mathrm{kVA}, \mathrm{AC} 11$ & LDP project by MASSAGSFO. \\
\hline Raman Lidar & $\begin{array}{l}\text { Sometime in } \\
\text { 1s93? }\end{array}$ & Hora tor SGP & $\begin{array}{l}19932 \% \\
1, \mathrm{CF} \\
\end{array}$ & $\begin{array}{l}\text { Hustr cama in } \\
\text { traifer }\end{array}$ & Unaknown, much & Sill early in IDP projea \\
\hline Scanning Lidaf & $\begin{array}{l}\text { Sometima in } \\
\text { 1994? }\end{array}$ & Hona tor SGP & $\begin{array}{l}1994 ? \\
1 . \mathrm{CF}\end{array}$ & Irailer & $\begin{array}{l}\text { Unknown, } \\
\text { injuch }\end{array}$ & Still early in IDP projaci. \\
\hline Scanning Radar & $\begin{array}{l}\text { Someting in } \\
\text { 1994? }\end{array}$ & Hone Ior SGP & $\begin{array}{l}1994 ? \\
1 . C^{2}\end{array}$ & Trailer & $\begin{array}{l}\text { Unknown, } \\
\text { much }\end{array}$ & Still early in UDP projact. \\
\hline 60-m Tower & $\begin{array}{l}\text { Apr. } 19921 \\
a\end{array}$ & Nara tor SGP & $\begin{array}{l}\text { Apr. 1992 } \\
\text { 1. CF }\end{array}$ & Nare & $2.5, W V_{1}, A C \quad 11$ & $\begin{array}{l}\text { Powet is for elevators; } \\
\text { otherwisa about } 500 \mathrm{~W} \text {. }\end{array}$ \\
\hline $\begin{array}{l}\text { Edoy Corelation Gear for } \\
\text { Tall Towat }\end{array}$ & $\begin{array}{l}\text { Apr 1992! } \\
0\end{array}$ & hiona for SGP & $\begin{array}{l}\text { Aps } 19921 \\
\text { 1. CF }\end{array}$ & $60 \mathrm{~min}$ towef & $100 \mathrm{~W}, \mathrm{AC}, 11$ & $\begin{array}{l}\text { Consists of } 2 \text { sonics, } 2 \\
\text { chypromaters, ona compuler. }\end{array}$ \\
\hline $\begin{array}{l}\text { Tomp, Hum., Wind Ota en } \\
\text { Tall Tower }\end{array}$ & $\begin{array}{l}\text { Apr. 19921 } \\
0\end{array}$ & Hora for SGP & $\begin{array}{l}\text { Apr. 1992! } \\
\text { 1. CF }\end{array}$ & $60-\mathrm{m}$ lowef & $10 \mathrm{~W}$ & $\begin{array}{l}\text { Shapas computer with provious } \\
\text { itam. }\end{array}$ \\
\hline Aerosol Observations. & Agr. 1592 & Nopa tor SGP & $\begin{array}{l}\text { Apr. } 1992 \\
\text { 1. CF }\end{array}$ & Trailer & $1 \mathrm{kVA}, A C$ if & $\begin{array}{l}\text { Power lof trailer; focated near } \\
\text { 60-m tower. }\end{array}$ \\
\hline $\begin{array}{l}\text { BSAM Broadband Solas and } \\
\text { IA Sensors }\end{array}$ & Apr. 1992 & Nona tor SGP & $\begin{array}{l}\text { Aff. } 19921 \\
\text { 1. CF }\end{array}$ & $\sin$ & $100 \mathrm{~W}, A C$ II & $\begin{array}{l}\text { Fiold data acquisition System also } \\
\text { neadod. }\end{array}$ \\
\hline NEA & $\begin{array}{l}\text { Apr. 1992/ } \\
\text { Fob. } 1993 \\
\end{array}$ & Nona for SGP & $\begin{array}{l}\text { Apr } 1992 t \\
\text { 1. CF }\end{array}$ & $\begin{array}{l}\text { Shoter with } \\
\text { rool epenias? }\end{array}$ & A W WA, AC II & $\begin{array}{l}\text { First Syblem is prototypo } \\
\text { provided by IDP. }\end{array}$ \\
\hline $\begin{array}{l}\text { Oher IDP Radiometie } \\
\text { Sensors. }\end{array}$ & 2 & $?$ & 1. CF & Usuatly traiburs & Unknawn, mugh & Early in IDP projocts. \\
\hline $\begin{array}{l}\text { Radiomotric Sonsors for } \\
\text { Fall Towar }\end{array}$ & $\begin{array}{l}\text { Apr } 1992 \\
\text { a }\end{array}$ & Mona lor SGP & $\begin{array}{l}\text { Apf } 19921 \\
\text { 1. CF }\end{array}$ & 60:m towar & $10 \mathrm{~W}$. $\mathrm{E}$ II & $\begin{array}{l}\text { Fower noedgd lor vent and } \\
\text { thermal conirol. }\end{array}$ \\
\hline
\end{tabular}


Table B.6 (coninued)

\begin{tabular}{|c|c|c|c|c|c|c|}
\hline Instrument Systerm. & $\begin{array}{c}\text { Dalivery } \\
\text { Dateroptions }\end{array}$ & $\begin{array}{l}\text { Addifional } \\
\text { Procurements }\end{array}$ & $\begin{array}{c}\text { liext } \\
\text { Installauon } \\
\text { When Where }\end{array}$ & $\begin{array}{l}\text { Struchures } \\
\text { Noedod }\end{array}$ & $\begin{array}{l}\text { Power } \\
\text { Nomiad }\end{array}$ & Comments \\
\hline Absolute Radiometers: & $\begin{array}{l}\text { Apr. } \\
0\end{array}$ & Nona tar SGP & $\begin{array}{l}\text { A.pI } 1592 \\
\text { 2. CF }\end{array}$ & $\begin{array}{l}\text { Calibration } \\
\text { facilities }\end{array}$ & DONAC if & $\begin{array}{l}\text { One operated continuously and one } \\
\text { a "shelfo reference. }\end{array}$ \\
\hline Solä Spectroradismeter & $\begin{array}{l}\text { Sompime in } \\
19921 \text {. }\end{array}$ & Hone for SCP & $\begin{array}{l}\text { Samelime in } \\
199211 \text { CF }\end{array}$ & $\begin{array}{l}\text { Calituatien } \\
\text { facilities }\end{array}$ & $159 \mathrm{WN} A \mathrm{AC}$ & Continuous operation questionabla. \\
\hline UV Spectral Radicmetar & $\begin{array}{l}\text { Sornelime in } \\
1992\end{array}$ & Hiona for SGP & $\begin{array}{l}\text { perhaps Apr. } \\
1992\end{array}$ & $\begin{array}{l}\text { Frama or } \\
\text { plaitorm }\end{array}$ & $10 \mathrm{~W}, \mathrm{AC}$ II & $\begin{array}{l}\text { USDA instrument made by SUNY } \\
\text { Albany. }\end{array}$ \\
\hline Calibration Facilities & $\begin{array}{l}\text { Apr. } 19921 \\
0\end{array}$ & None tor SGP & $\begin{array}{l}\text { Apt } 19921 \\
\text { 1.CF }\end{array}$ & $\begin{array}{l}\text { Two traiters } \\
\text { and platome }\end{array}$ & $\begin{array}{l}2.5, \mathrm{VA}, \mathrm{AC}, \mathrm{if} \\
\text { and } 31\end{array}$ & $\begin{array}{l}\text { floguiras puchase ol two trailers, } \\
\text { special platorm. }\end{array}$ \\
\hline \multicolumn{7}{|l|}{ AF* } \\
\hline All-sky tmaging System & $\begin{array}{l}\text { Apt } 19921 \\
\text { Dec. } 1992\end{array}$ & $\begin{array}{l}\text { Total of soven } \\
\text { units ngeded }\end{array}$ & $\begin{array}{l}\text { Apr } 19521 \\
\text { 1.CF: } 1 . \mathrm{AF}\end{array}$ & Mone & $200 \mathrm{~W} A C$ & $\begin{array}{l}\text { Number speciniad in oplions } \\
\text { clepends on price. }\end{array}$ \\
\hline \multicolumn{7}{|r|}{ 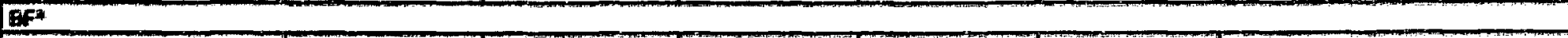 } \\
\hline $\begin{array}{l}\text { RASS for NOAA } \\
\text { Wind Protilers } \\
\end{array}$ & $\begin{array}{l}\text { Sometime in } \\
\text { 19a2A. }\end{array}$ & Hora far SGP & $\begin{array}{l}\text { Serreting in } \\
199214 \text { Bf }\end{array}$ & Already exist & Nolappl. & $\begin{array}{l}\text { The number to be puctiased by } \\
\text { Aful is uniknown. }\end{array}$ \\
\hline \multicolumn{7}{|l|}{ E } \\
\hline $\begin{array}{l}\text { Surtace Mblecroil Obs. } \\
\text { Slations }\end{array}$ & $\begin{array}{ll}\text { Apt. } 1992 / \\
\text { Siept }: 992 \\
\end{array}$ & Hona far SGP & $\begin{array}{l}\text { Apr } 19921 \\
\text { 1.CF:A.EF }\end{array}$ & $\begin{array}{l}\text { Comes with } \\
10-m \text { tower }\end{array}$ & $\begin{array}{l}20 \text { W solar or } \\
A C \text { if }\end{array}$ & $\begin{array}{l}\text { Commercial version of PAM-like } \\
\text { station. }\end{array}$ \\
\hline $\begin{array}{l}\text { Flux Char. Sta: } \\
\text { EER: }\end{array}$ & $\begin{array}{l}\text { Apr - Dog- } \\
10021 \text {. }\end{array}$ & grotably none & $\begin{array}{l}\text { API } 19921 \\
\text { 1. CF: \& EF }\end{array}$ & $\ln \theta$ & $\begin{array}{l}20 \text { W. solar of } \\
\text { AC if }\end{array}$ & $\begin{array}{l}\text { Fiva additional Systams to be } \\
\text { installed in } 1992 \text {. }\end{array}$ \\
\hline $\begin{array}{l}\text { Flux Char. Sta: } \\
\text { Eddy Corrolation }\end{array}$ & $\begin{array}{l}\text { Ape \& इBC } \\
\text { 19921Apr. "93 }\end{array}$ & Hone for SGP & $\begin{array}{l}\text { Apr. } 1921 \\
\text { AEr }\end{array}$ & Mane & $\begin{array}{l}20 \text { W. selar or } \\
A C \text { il }\end{array}$ & Lnstalled in lilled areas. \\
\hline Flux Benchmarking Sution & $\begin{array}{l}\text { Jun } 19921 \\
0\end{array}$ & Hone lor SGP & $\begin{array}{l}\text { June } 19921 \\
\text { i. EF Q CF }\end{array}$ & Mang & $\begin{array}{l}50 \text { W, solar or } \\
4 C \text { if }\end{array}$ & $\begin{array}{l}\text { Roving System for comparing to } \\
\text { flux scations. }\end{array}$ \\
\hline $\begin{array}{l}\text { Sel of Wideband Solar and } \\
\text { iA Sensors }\end{array}$ & $\begin{array}{l}\text { Apr } 19921 \\
\text { Doce } 1992\end{array}$ & 15 more tor SGP & $\begin{array}{l}\text { Apr. } 19921 \\
\text { I.CF. } \mathrm{AEF} \\
\end{array}$ & $\begin{array}{l}\text { Frame cr } \\
\text { platform }\end{array}$ & $\begin{array}{l}10 \text { W. solar of } \\
\text { AC It }\end{array}$ & $\begin{array}{l}\text { Powa neaded for vent and } \\
\text { thermal control. }\end{array}$ \\
\hline Mutrifiltar FSA & \begin{tabular}{|l|l|} 
Apr. & 19928 \\
Doc. 1992
\end{tabular} & More lor SGP & $\begin{array}{l}\text { Apr. T992I } \\
\text { 1. CF: I EF }\end{array}$ & Nama & $\begin{array}{l}50 \mathrm{~W}, \text { solar or } \\
\text { AC : }\end{array}$ & $\begin{array}{l}\text { Max. power is for thermal control } \\
\text { in cold weather. }\end{array}$ \\
\hline
\end{tabular}

Abbroviations: AF = Muxiliary facilisy. BF = Boundary Facility. CF $=$ Central Facility, and EF = Enendod facility.

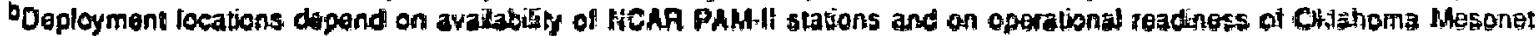

Exast location al deploymons depends on noeds of experiments.

Insludes ona for contral lacility and. as apprptale, instruments for bounday lacility locations. 


\section{Tentative List of Trailers tor CART Site}

(All shelters include at least $15 \mathrm{~A}, 1 \mathrm{15} \mathrm{V} \mathrm{AC}$, for heating and cooling.)

\section{Contral Facinty}

One shelter, special acquisition, tor 2 AERIs, other high-resolution intrared interferometers, ceilometer

Lueated near senter of Central Facility, neaf aray trit radiometers

* fo $x$ 40) fit semi-trailer

Special openings in root for sill systems

At least 60 A, maybe 100 ) A, $145 \mathrm{~V}$ AC

One shelter, special acquisition, for aerosol observations, howsing nephelometer, particle size sensor, fitter, ozone sensor, etc.

Exact location not specified, probably near 6()-m tower

8 fit $x 10$ ft truiler or container

Piping to outside to collect samples

50 A. I 15 V AC

One shelter, special acquisition, for electronius for the protilęr-RASSs

Within tence near 50-MHz and 915-MHz radar wind profiler-RASSs

8 ft $\times 10$ ft trater

Conduits tor cables

50 A. $115 \mathrm{VAC}$

One sheiter. comes with balloon-borne sounding system. for balloon-bome sounding system (in fenced area)

$816 \times 12$ tr trailer

Special opening in roof tor balloon release

50. A. 115 V AC

One shelter. special acquisition. dick and storage area (in fenced area)

$25 \mathrm{ft} \times 30 \mathrm{ft}$ storige and $5 \mathrm{ft} \times 30 \mathrm{ft}$ dock

50) A. $115 \vee \mathrm{AC}$

Onte shelter, speciat acquisition. for calibration facility for fadiontetric observations (in fenced area) to $\times 60$ ft mobile home

Needs optics lab. duta acquisition room. work area. and a spectal stand outside and perhaps above the shelter. for radiometric sensor comparisons

60 A. $115 \vee \mathrm{AC}$ 
One shelter, special acquisition, for aftice, laboratory area, control area (in fenced area) $10 \mathrm{ft} \times 60$ ft mobile home

$60 \mathrm{~A}, \mathrm{LI} \mathrm{V} \mathrm{AC}$

Onner tuture possibilities incide separate shelters for Raman lidar, scanning lidar, scanning radar, each a semi of about $7 \mathrm{ft} \times 40 \mathrm{ft}$, each with $30-60 \mathrm{~A}, 115 \mathrm{~V} \mathrm{AC}$.

Goundary Facility (at each of six)

Requiremenks for shelters depends on instruments locited at boundary facilities.

Probably one shetter ( 7 th $\times 40$ th semi-trailer) is required with a hole in its roof to house an AER!. wotkshop, office area: 50 $\mathrm{A}_{0} 115 \mathrm{~V} \mathrm{AC}$ is needel.

Small shelter is required for electronics for wind protiler-RASSs if ARM needs to acquire such tor the boundary tucilities (as at the central fucility).

Shelter is needed for ballogn-borne sounding system fas at the central ficility).

Storage shelter. $10 \mathrm{ft} \times \mathrm{t} 0 \mathrm{ft}$ is needed. 
B. 16 


\section{Appendix C}

Degcripitons of ARM-Retated Equipment and Instruments 


$$
\text { C. } 2
$$




\section{Appendix $\mathrm{C}$ \\ Descriptions of AFîn-related Equipment and Instruments}

This appendix gives a brief description of each of the instruments proposed for use by the ARM Progfam at the southern Great Plains CART location. Because of the interest in the ARM Program in data throughout the troposphere (depth $12-15 \mathrm{~km}$ ). much of the instrumentation involves remote probing. Other, direct measurement sensors will be mounted on small towers. Remote sensing systems may be classified as active or passive. Active systems illuminate the abject of study with their own supplied energy. whereas passive systems sense naturally uccurring (emitted thermal or reflected solar) radiation. A passive systert is inappropriate at wavelengths at which insignificant amounts of radiation wetur naturally. An active system may not be technikatiy

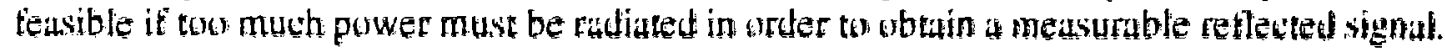

\section{C.t 915-MHz Radat Wind Protler and RASS Systems}

The $915-\mathrm{MH} / \mathrm{z}$ wind profiler system is a continutusly ogerating radar that enits an upward microwave signal at 915-MHz. The Doppler shift tin the reflected signal trequency is measured as a function of altitude. The amount of shift can be used to determine a profite of wind speed and direction. Although this radiur is designed to transmit the signal vertically. side lobes are emilted horizontally. However, thesse side lobes are mitigated easily by a simple fente that encompasises the radar antenna. and they do not pose salety problems for personnel. Operuted in conjunction with the mistowave eadaf, a RASS provides further meteorological information. The vertically pointing RASS (up to three transmitters/teceivers that operate simulanecusly) emits sound pulkes in the range of $1560-20100 \mathrm{~Hz}$ for $5-6$ min 30 ar 60 min. The sound pulses can be tracked by the radar and analyzed to determine virtual temperature is a function of height. In a moist atmosphere. the virtual temperature is the temperature of dry air having the same density and pressure as the moish air. An independent profile of temperature like that thom balkon-borne systems ullows. in principle, the amount of moisture (a critical parameter to be measured in the ARM Program) in the atmosphere to be determined as a function of height. The RASS also produces horizontal side lobes: these are mitigated to non-annoying noise levels by somb bafhes and distante criteria in siting. Because buth the microwave signal and the sound pulses are significantly atuenuated in the tower atmosphere. this radar and the RASS syitem is used to investigute wind speed. wind direction. and virtual temperature only from about $100 \mathrm{~m}$ above the surfiace to heights of about $1.2 \mathrm{~km}$.

\section{C.2 The 50-MHz Wind Protller and RASS Systems}

The 5()-MHz wind profiter and RASS system is similar in concept to the $915-\mathrm{MHz}$ and RASS radar system. except that the microwave signal is $50-\mathrm{MHz}$, and the sound pulses are at 5(1) +100$) \mathrm{Hz}$. However, this microwave signal and the sound pulses (up to three transmitters) are less altenuated in the lower atmosphere and are used to investigate wind speed. wind direction. and virtual tempersture through the entire atmosphere depth of $12-15 \mathrm{~km}$. However, because of the 
longer pulse wavelengths, the signals are not resolvable much below $2 \mathrm{~km}$. Furthernore, the horizontal component of the sound pulses at the lower sound frequensy is more difficuth to mitigate. Mitigation is usually accomplished by using more rigorous siting criteriag.

\section{C.3 Balloon-borne Sounding System}

A large helium-filled balloon caries a small (55 x $147 \times 90 \mathrm{~mm}$ ), lightweight (260) gams; with battery) battery-operated instrument package that transmits temperature, humidity, wind direction, and wind speed information as a function of pressure altitude. The ballown carries the instrument package up to about 30 ) routinely used by the Narional Weather Service. The instrument parkage is returned sately to the surtace by parachute atter the ballown bursts.

\section{C.4 60-m Tower Instruments}

Towers are the standard plattorms for continuous metectologitat investigations of the lowest $100 \mathrm{~m}$ of the atmosphere. Standard metebrologeal instrantents will he used to measure wind speed and direction, temperature, humidity. pressure. downwelling radiation chte sun"s radiant energy that reaches the earth's surface), and upwelling radiation (the sun's rudiunt energy that is reflected upward by the surface). These measurements will be matle at the $25=5 \mathrm{~m}$ and 6 ain $\cdot \mathrm{m}$ levels.

\section{C.5 $10-\mathrm{m}$ Standard Meteorological Measurement Tower}

Standard meteorological instruments are used to measure wind speed and direction. air and soil temperature. humidity, pressure, and tain rate. The instruments require little power and could be operated by solar power.

\section{C.6 Surface Flux Station}

Standard meteorologizal instrumentation (Bowen ratio methed) is used to determine the net rate (flux) over about 30-60 min of the gain or loss of temperature. movisture. and momentum at the earth's surface. The individual instruments are muonted on a platform abovi $1.3 \mathrm{~m}$ above the surface. These instruments require little pewer and san be operated by solar power. Another method for thx measurements is by edlly correlation technique. Again. standard metenorolngical instrumentation is used. but the platiom height for the sensors is $3-10 \mathrm{~m}$. Standiard porver is also required. 


\section{C.7 Passive Milcrowave Radiometer}

The vertically pointing passive microwave radiometer passively measues the amount of naturally occurring, thermalty generated microwave ratiution in the atmosphere at certain wavelengths in the infrured radiation bands corresponding to atmospheric water.

\section{C.8 Cellometer}

An eyerafe laser light source is used to transmit a narfow-bean. pubed hight source vertically. The ceiloneter is used to mausure heights of ctoud buses from the time botween rransmission and reception of the reflected light pulfe. This instrument is similar to that used by the National Weather Service to deternine cloud base heights, except that the mure powertul

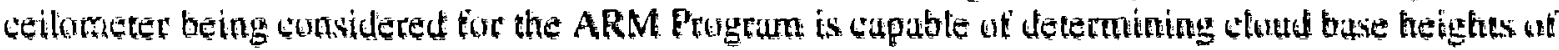
higher clouds such as cirrus (approximately $10 \mathrm{~km}$ ).

\section{C.9 Wholes Sky Imaging}

A vertically pointing camera takes pictures of clouds with a wide angle lens. Instead of tilm. a high-density matrix of light-sensitive cells converts pictures into electronic images that in conjunction with other whote-sky cameras and a computer, can produce three-dimensiunal images ut clouds.

\section{C.to Lidar}

A LIDAR (Llght Detection And Ranging) transmits a pulse of namow-beam laser light (usually intrared rudiation) into the atmosphere and detets the reflection sume tine later. By measuring the time delay and knowing the speed of propagation of the light pulse. the height of the reflecting elements can be determined. Small partictes finctuding small water foropless and ice erystals) in the atmosphere are efticient lidar-feflecting eleme.ts. These particles follow wind motions: therelore, some lidars cun determine wind speed and direction. Sume lusers are eye sate. but others are not. The ARM Program will use both types. The non eye-safe laser is uperated in a safe manner by using a smalt radar with a wider microwave beam than the fuser beam. As any object comes inter the path of the microwave beam. the power is automatically shut off to the laser light until the radiar indicates that the object is clear. Lidars reaching to the top of the tropesphere $(10+12 \mathrm{~km})$ have large pinwer requirenents.

\section{C.11 Radar}

A RADAR (RAdio Detection and Ranging) is an instrument used for the detection and ranging of distant "objects" that reflect radio-wave energy. The trequency or time relationships between the transmitted signal and the echo are used to determine the location of the reflecting elements, including particles carried by wind and all forms of precipitation (rain. sleet. hail. ice 
crystals, etc.). Radars can be used in a vertical pointing mode or in a scanning mode. The National Weather Service uses "weather" radars that show the location and movement of precipitation. The ARM Program will employ similar radars for its studies.

\section{C.12 Speclalized and Broadband Radiometers}

A number of different types of solar radiation instruments tsuch as pyranometars, pyrgeometers, shadow-band radioneters, high-tesolution spectometers, eto.) to be usef by the ARM Frogram operate similarly, Incoming and outgoing solat eadiation is passively determined by ratisuring the amount of electrical power required th equalize the temperature of a knawn swurce and the temperature of a blatkened theat adswbing) metal strip heated by the sun (incoming) or the reradiance and/or teflection of the sun's energy by the surface foutgoingt. Theretore. cadiometers are passive meusurement instruments. Tokat solar moliutikn is it combination of direct and diffuse sunlight. Dittuse suntight is determined by shielding the cadiometer trom difese sunlight to measure the general brightness of the sky. Browdband fadioneters integrate schar radiation over many wavetengths. Spectialized adiometers lowt at sulut fadiation through very natrow ranges of wavelengths that are impontan in the detemonation of the effect of water vapor (humidity) wn toul solar radiation.

\section{C.13 Air Pollution Instrumentation}

Various instruments measure particles fintegrating nephelometers. optical particle anolyzers, etce) and gases (ozone, surbora diexile, etc.) by drawing atutside air into the instrument fior conllection und/er analysis. 
Appendix $\square$

Letters wom Consutting Aganctas 
D.2 


\section{OHlahoma Historical Society Founded $M_{9 y} 27,6893$}

STATE HISTORIC PRESERVATION OFFCE

621 N. ROBINSON, SUTTE 375. OKLAHOMA CTY, OK 73102 " (405) 521-6249

November 12, 1991

Mre. Jack Pingston

Enviconmental Assessment Division

ARCONAE NATIONAL HABORATORY

9700 5. Cass Ave.

Artonne, Inthiois 60439

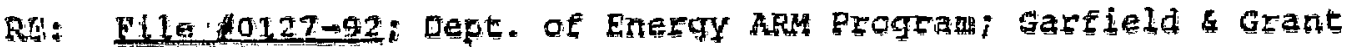
counties, oklahoma

DataF Mr. PElngaton:

We have recefved and bulewed the documentation submitted concerning the reterenced pefect.

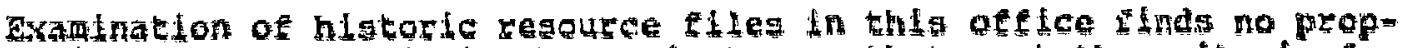
erties documented with tha project wea that met the caltera ror ligtirig on the Mational Rephas of Histore Places. our roserseh indieates that tharo is little ibkelihood such historfc propertefos wII oceur:

In addition to review by this office, a reviev focusing on prohistoric resources by the Oklahoma Rraheolegical survay is required for detarmining the pragance of National Regheter quality prohistoric atea. Documentation on any higtoric archioologicar olte digcovared in the course of arehaeologteal survays should bo subnttad to the state Historic prosnitution ofelce cor coviuw. Thlo is an intogral pare of that Section 106 process.

Should the oklahoma Archeological survey conelude that thero are ro prehistoric archaeological sites of National Register guality, rind should no historlc stte have been discovered in the procass ce survey, the state Historic pregervation office finds no propartice eligible for tha National Register of Historic Places wthin the refirenced project boundaries.

Should Iurther correspondence pertaining to this project bo nocessary, the above undertined tle mumber must be refezenede. It you have sry quastions, plaasa contact MF. Marshall Geteys, Mittorteal Archaeologist, 4te 405/521-6249. Thank you.

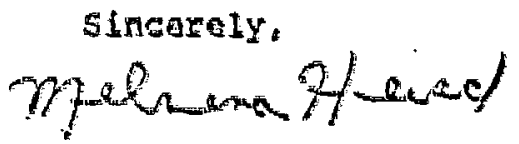

Mezvana Heisch

Deputy state Historic Regservation officer

MPI : pII 


\section{Lniversity of Oklafioma}

OKLAHOMA ARCHEQLOGIGAL SUAYEY

1EQQ Nawton Drive

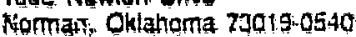

(405) 325.7211

November 19, 1991

Jack Peflagaron

Af gonne Nathonal Labofatom

9700 South Caras dventue

Afgonac, Iflaots 60439

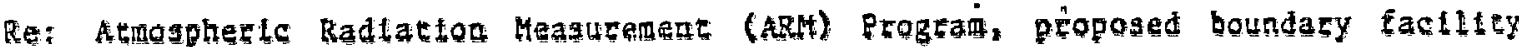

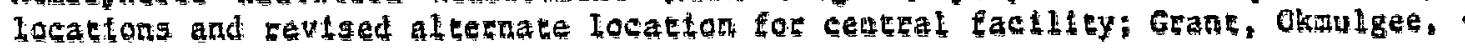
Meclatn, and Hoodward Countes. OhIahoma

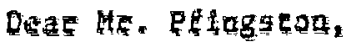

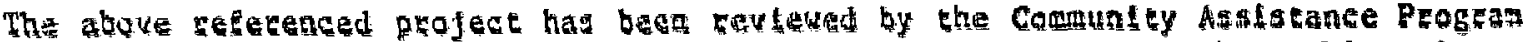

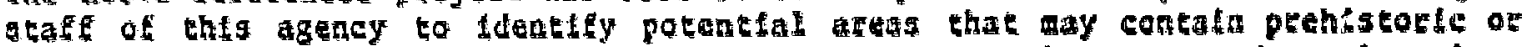

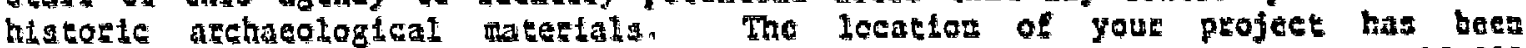
cross-checked with the state stee flleg contatulag approximately 13,000 archaeologtcal glees which are curcently recorded for the state of oklahowa. No prehistorte or higtorfe sites are recorded to of near your project area. Fos jost

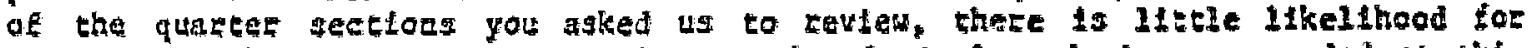
atehaeologtcal gtteg to occus, and no archaeotogteal work is recomended at this

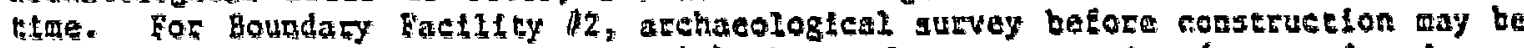
Heckssary depending ol the locaton(s) chosen for constacton (set enclosed copy trom crine 7.5 quadeangle map). The anclosed table sumbaties the locations covelewe and our recomandatlons.

I have enclosed a Ilge of contract atchatologists who cen do the fleld survey it necessary. Zlease call us th there are any questlons.

Thts anvironmantal seview and evaluatlon is performet in order to locaso, record, and preserve Okiahoua's prihtstorte and historte culcural herleage la couperatiod

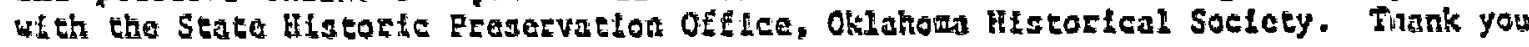
for Your cooperation.

stnegrely,
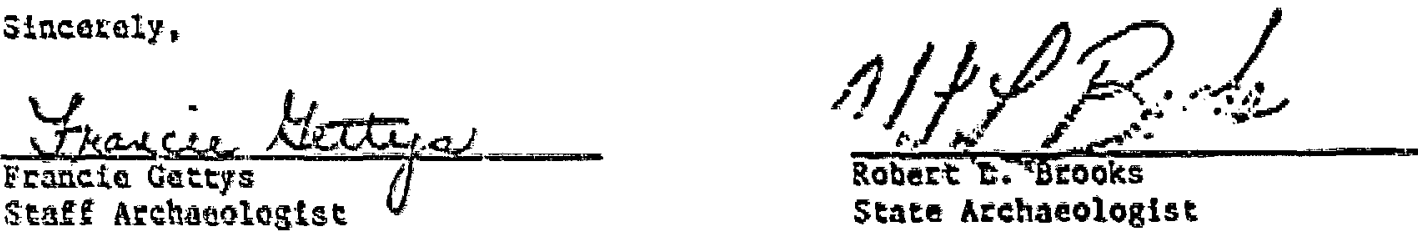

CE: $\$$ SHPO

eocl: table

the

Ilst of contrastors 


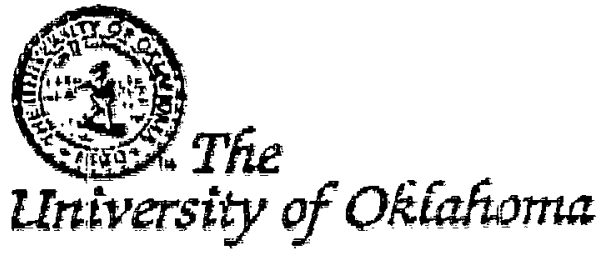

OKLAHONE ARCHEOLOGICAF SHAVEY

1800 Nowton Drive

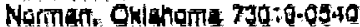

(405) 3257211

Decentres 17. $\$ 991$

Jacls Pagason

Axpoane Nationgl Labogatory

9700 South Caga Avents.

Argonat. IIIInots 60439

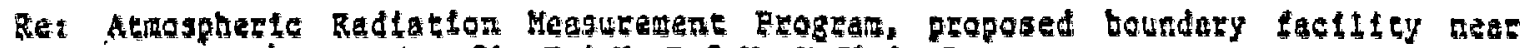

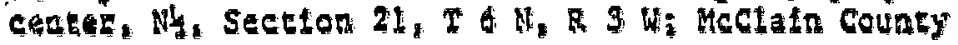

Detar Mr. Pftogaton.

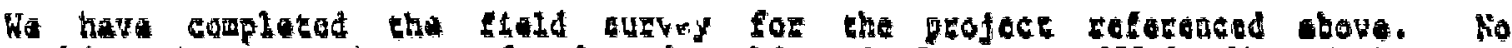

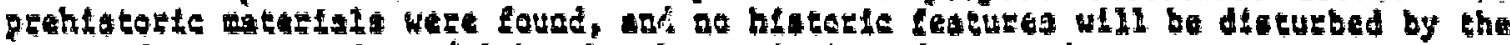
zropoged congtruction (alebough the extsting farmetesd io old enough co be

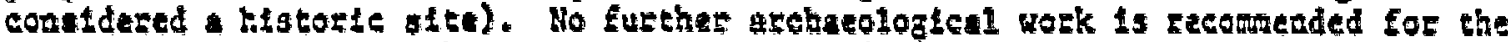
ridge fat the centere of the north halE, Section 21 . If your land use plens hould

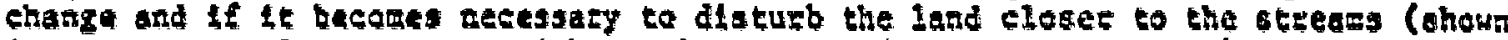
th orange on the map ent wt th our letegr dated hovenbez 19, 1991), please let us

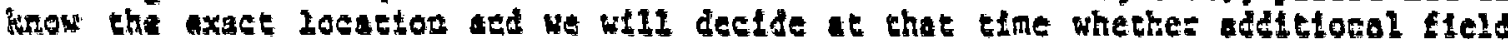
Qurvey to gecegsary.

If thara see any questons, please cell ua. Thank you tor your cooperation and sgriteranch.

stacerty,
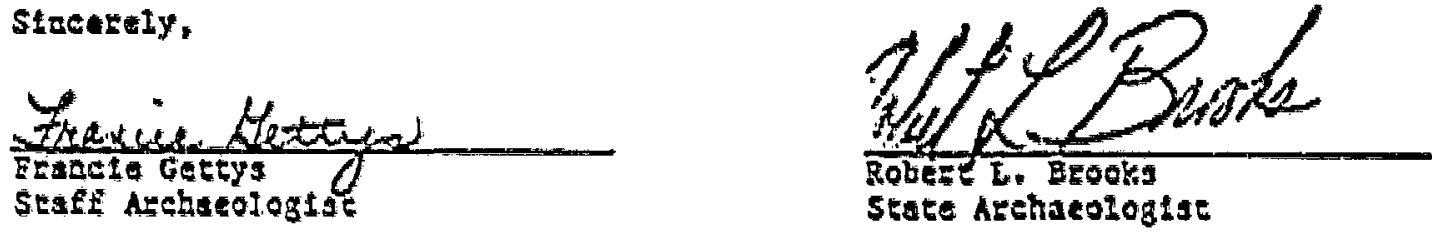

CC: SEFO 


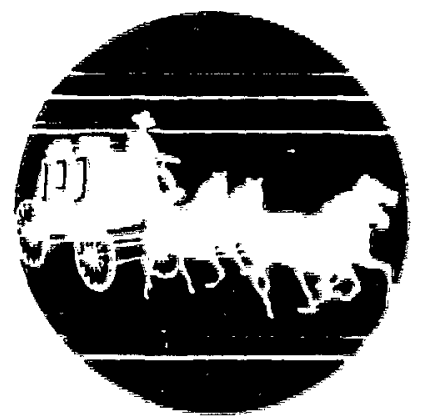

Novermber 19, 1991

\section{KANSAS STATE HISTORICAL SOCIETY}

\section{HISTORIC RRESERVATION DEPARTMENT}

Center for Historical Research

120 West Tenth * Topelon, Kangas 660ั12-1291

$913-296-7080+$ FAX $913-296-1005$

fack Pringaton

Social and Natural Regourcess Section

Asoonme National katoratory

9700 South Cass Avenue

Argonne, tllinois 60432

Re: Almospheric Radiation Measurement Program

Buondary Site Locationa in Kansas

Deat Mr. Ptingston:

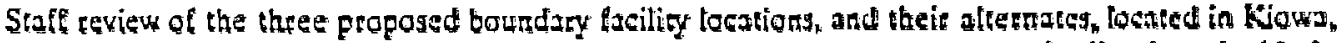
Atation, and Montgomery counties has been completed. There ate vo propetties listed os the National

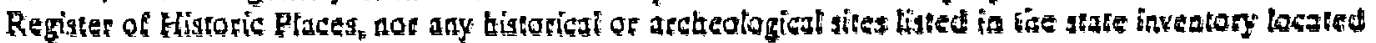

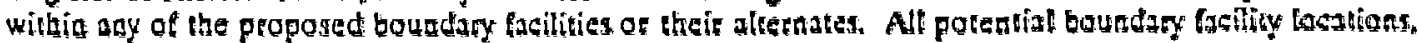

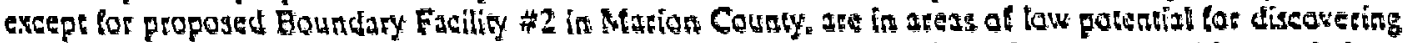
the surface indications of prehistoric archeological sites ant no archeotogieal survey shoutd be aceded.

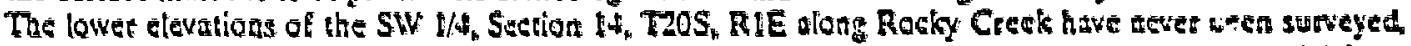
but, basch upon an analysis of recorded prehistoric sites in the tegion, it appests thete is a potential for prebistorie archeologicat sites to be located there. We wish to teviets the sperifie location of the boundary acilly within the ore-quatter section, if this location is atosen.

If you have questions or need additional infoumation. please conmet Mte Mtartin Stein at $\$ 13$ 296-5294.

Sincerely yours,

Raman Pawers

Stute Histotic Preservation Olficet

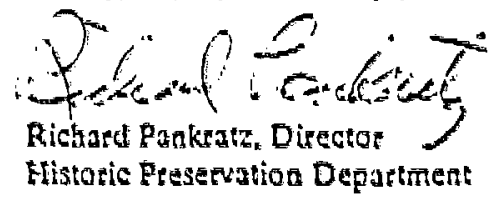

RP/RE 


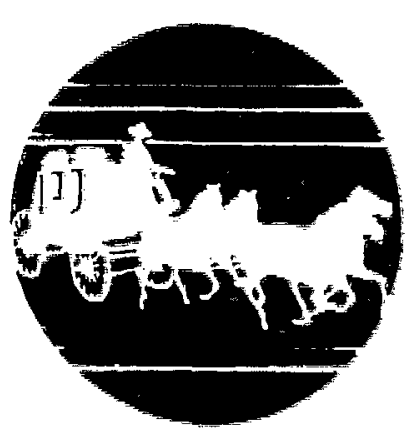

Decenbar 2. 1991

\section{KANGAS STATE HISTORICAL SOCIETY}

\section{HISTORIC PRESERVATION DEPARTMENT}

Center for Historical Research

120 West Tacth Topekg, Kangas 6661\%+129!

913.396-7080 * FAX 913-296-1005

Jack Pfington

Social and Narunal Rerources Section

Atgone National Laboratory

9700 South Cass dreate

Argonge, ILinois 60439:

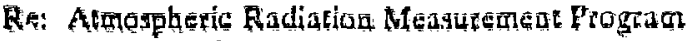

Doundary Site Lecationg in Kanats

Dear Mr. Plingston:

Saff review of the three proposed bourdary facily locatioss, fad their alternates, locuted io kiow:. Marion, and Montgonery counties has been completed. There are go properties listed on the National Register of Historic Places, to any bistorical or archeologital sites listed ia the state inveorory located

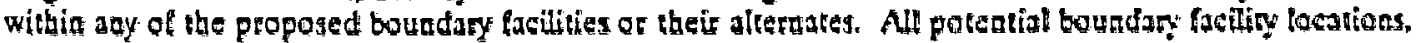
except for propoged Beundary Facifty 2 in Mariog County, ate is areas of low potential for diseoveriog

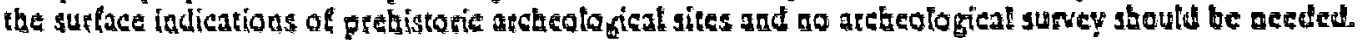

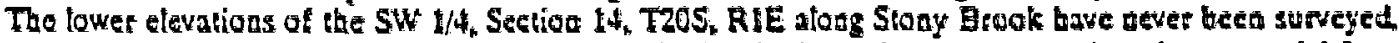
but, based upon ad analysis of recorded prebistotic siles in the segion, it agpests thete is a poteatiol for prebistoric archeological sites to be tocated there. If the tasiling is located above 1450 leet MSL no areheologieat survey will be deeded. If construetion takes place below the 1450 foot contour line, we recotutend an arcbeological survey be done. We uaceestand coustruction of the facility will iske place ou the bigher grougd and we ba*e no objectiog to that.

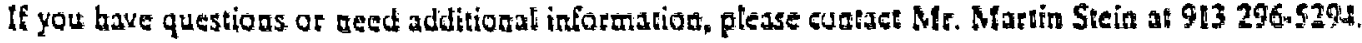

Sincerely yours,

Rantod Powers

State tlistonic Preservation OrGer

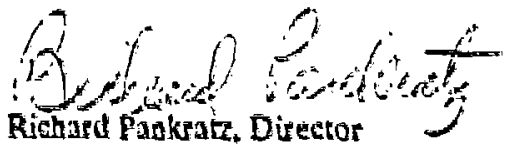

Historic Preservatiod Departencet

RP/OLS 


\title{
United States Department of the Interior
}

\author{
FISH AND WILDLIEE SERVICE \\ Kansas State Otice \\ 315 Foustom, Suito E \\ Manhattann Kansas 6650?
}

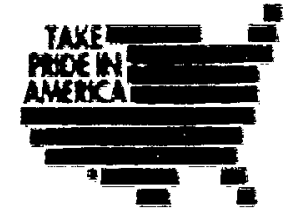

Qctober $23_{\mathrm{n}} 1991$

Jack Pringston

Environmental Assegsment and triormation

Sciences Division

Argonne National Laboratory

9700 South Cass Avenue

Afgonne, Illinois 60439

Dear Mr. Pringston:

This is in response to your October 15,1994 letter requesting threatened and endangered species information relative to your proposed Atmospheric Radiation Measurement Stations in Kansas and Okjatromid. The fotlowing infunnation is providad for your consideration.

In accordance with Section 7(e) of the Endangered Species Act (16 U.S.C. IS31 et seq.), we have determined that the following federally listed species may oceur in the project area: piping plover (Charadrius melodus), least tern (Siern antitlarum), bald eagle (Halineetus levcocephalus), peregrine falcon (Falco peregninus), whooping crane (Grus americana), black-footed fertet (Mustela nigriess), Neosho madtom (Noburus placidus), pallid sturgeon (Scaphirhynchus albus), Mead's milkweed (Asclepias meadii), and westem prairie fringed orchid (Rlatanthera preclara). Cheyente Bottons Witdlife Area in Barton County, and Quivira National Wildtife Refuge in Staftord County are federally-designated critical habitat for the whooping crane. If the project may affect listed species, the Department of Energy should initiate formal Section 7 consultation with this office. If there will be no cffect, or if the Fish and Wildlife Service concurs in writing thete will be beneficial effects, further consulation is not necessary. I am enclosing habitat and locational information for all tederally listed and proposed species in Kansas, which should prove useful in an assessment of the potential for impacts.

I an also enclosing a list of the category 1 and 2 candidate species which may occur in uie project area. Category 1 species are those for which sufficient information exists to support a listing. Category 2 species are those fot which the Service is seeking additional intormation in order to delermine their biological status, to facilitate any decisions regarding their potential for listing. Candidate species have no legal protection under the Ëndangesed Species Act; however, the Service is concerned for their conservation due to their uncertain 
status. The extent to which cetain candidate species may be impacted by this project will depend upon final site selection.

Please be apprised of the potential application of the Migratory Bird Treaty Act of 1918 (MBTA), as amended, 16 U.S.C. 703 et geq, and the Bald Eagle Protection act of 1940 (BEPA) as amended, 16 U.S.C. 668 el seq., to your project. The MBTA does not require intent to be groven and does not allow for "kake" except as permitted by gegulations ... it shall be unlawfil at any time, by any meang or in any mannet, to . . buke, captere, kill. attempt to take, capure, of kill posgess. . . any migratory bind, any part, nest, or eggs of any such birt . .." The BEPA prohibils knowingly taking, of laking with wanton distegard for the congequences of an ackivity, any bafd of golden eagles or their body pards, ntests. of egg, which includes collection, molestation, distubance, or killing activities. Please conact this office if you have any questions.

We further zecommend thak alt construction areas be gyrveyed for the pregances of marshas. tiver floodolains, and other wetland habita types. If impacts to these wress are erpected, a permit may be required from the US. Amy Cops of Enginaers. If a permit is required. the Service would review the application and provide recommendations.

Thank you for this opportunity to provide input on your progosalt.

Sincerely.<smiles>N#CC1C#CC=C1</smiles>

Wiltiam H. Gin

State Supervisor

Enclosures

ce: FWS/FWE, Denver, Co (Section 7 Coordinator) KDWP, Pratt, KS (Environmental Services) 


\title{
United States Department of the Interior
}

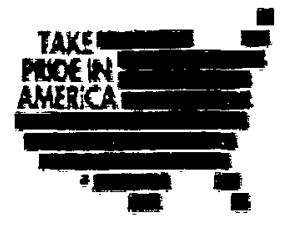

\author{
FISH AND WLDLIFE SERVTCE \\ Kansas State OTice \\ 3 ț̃ Houstom Surte $E$ \\ Manhattan, Kansas 66302
}

November 25, 1991

\section{lack Pfingston}

Envirotmental Asgessment and

Information Sciences Division

Argontre Nacional Laboratory

9700 South Cass Avenue

Afgonne, Mlinoig 60439

\section{Dear Me Pfingston:}

This is in response to your November $T_{\mathrm{s}} 1991$ letter and November 22, 1991 focsimile transmission to Dan Multem of this offte, regarding the proposed Atmosphteric Radiation Measurement Program in Kansas and Oklahoma. The following threatened and endangered species information is provided zelative to your altemative project sites in sowthem Kansas.

It appears from the site descriptions you provided that all alternatives occur in uphand areas, with no stream or river impacts. From this we would conese that the? is probably litule porential for impact to any fedenally-listed species from any of the sites you indieated in Marion or Monigomery County. This is also dependent upon there being no impacts to any marshes or other wetland habitats, or any areas ol native tallgrass prainie. These two counties each may contain populations of the prairie mote cricket, occupying native prainie sites. This insect previousiy had been proposed for fedenal listing, but recent field surveys have led to this proposal being withdrawn. However, it is still a candidate species for which the Service is concemed due to population declines.

In Kiuwa County, any wedands may possibly provide temporary stopover habiet for the whooping crane. If rangeland containing at least 80 acres of prairie dog towns is to te impacted, this would require a black-footed ferret survey prior to any construction. If cropland is the only land use to be affected, we would not anticipate any adverse effects to any listed species.

Other category 2 candidate species which may occur in tither grassland or woodland in these three counties include the eastem spotted skunk, ferruginous hawk, loggerhead shrike, Henslow's sparrow, Baird's sparrow, Texas homed lizard, regai fritillary buttërfly, earleaf foxglove, and hary false mallow. While candidate species have no legal prolection under the Endangered Species Act, the Service is concemed for their conservation due to their uncertain population stakus. 
If you have additional questions, please do not hesiture to contact our offiçe again. Thank you for providing us this opportunity to conment on your proposed project.

Sincerely,<smiles>C#CC(C)NC1CCCC1</smiles>

Whiam H. Gill

State Supervisor

DWM/WHG/dWm 


\title{
United States Department of the Interior
}

\author{
FISH AND WLDLIFE SERVTCE \\ Ecological Services \\ 2ge S. Houston, Sulice \\ Tulsa Oklahoma 74127 \\ Decenber 3. 1991
}

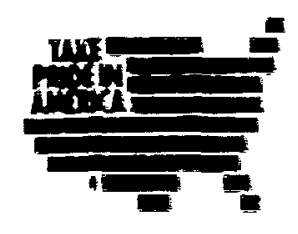

$12-14-92-I-48$

Mr. Jack Petrigaton

Environmental Asgessment and

Information Sciences Diwgion

Argonne National Laboratory

9700 South Gass Avenue

Argonne, Ilinolg. 60439

Dear Ha. Pfingston:

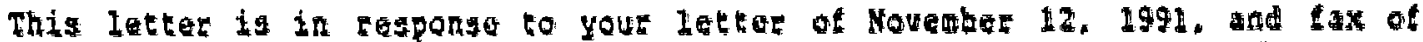
November 19, 1991, in which you advised us of the specitis sted and alternates selectek in OkIahoma for the htmogpheric Radiation Measurament (ARM) FEogram central facility and boundary sites.

Atthough geveral Faderally ltged threatened and endangered species are known

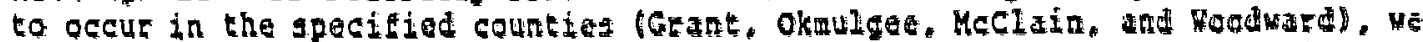

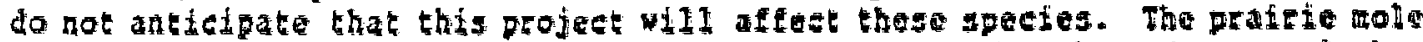
cricket (Gryllotaloa matos). cuegently proposed to bo tisted as thetethed, has been documented in McClatn atd okmulge counthes. Rovever. Ne have recoumended that the progosed rute to inst the spectes as ehreatened be mithdears. The Withdrawal has been sent to Washington and publication in the Federal Registeg is imminent. Site surveys cor this species will not be required.

The quater soctions containing the proposed stte and two alternatiwe sites selected for the centrat Facility do not have any nelands of coneern.

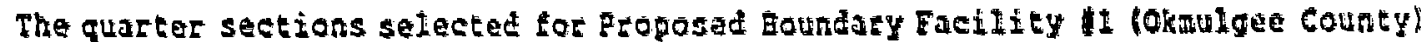

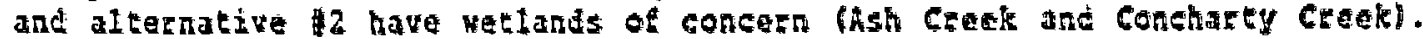
Alternative sites 11 and 13 do not have any weblands of concent. ISeu enclosed National Netlands Inventory aaps.

All quarter sections selected. Cor proposed sito locatian and both alterates.

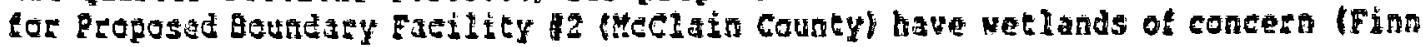
Cretek).

None of the quarter sections selected for Boundagy Facility (Woodward County) have retland's of concern.

In accordance vith Executive Orders 11990 iprotection of Wetiands) and 11938 (Brotection of Eloodplains). He recomaeni imyats to wetlands and stream areas (Eloodplain) be aroided by locating facilities in uplands sites. If work in 
Wetranda is unavoidable, we recommend the following procedures be implemeatef to reduce impacts and protect these sires:

1. Hetland hudrology should not be atered by draining. dedqing. of construction of dikes of $\quad$ ivers.

2. Heany aquipment should be kept out of all wetland azeas.

3. Vegetation elearing should be kegt to a minimum not only adjaent to

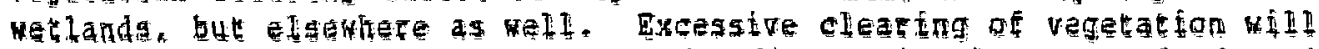

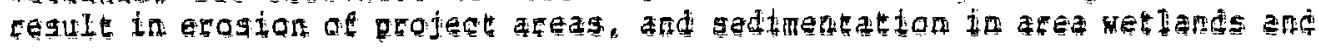
St tre

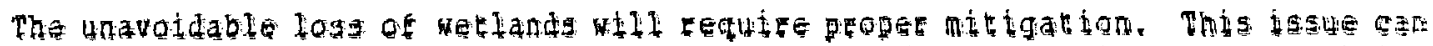

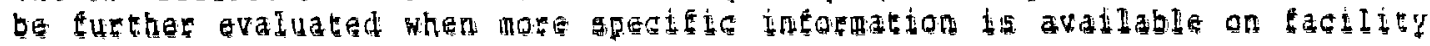
locations.

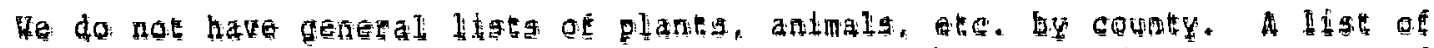

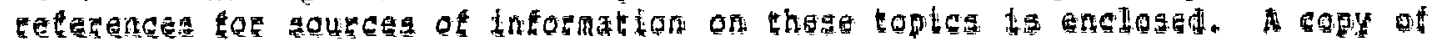

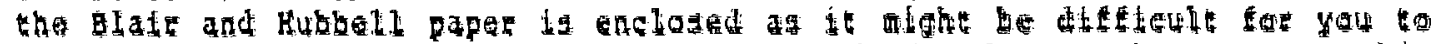

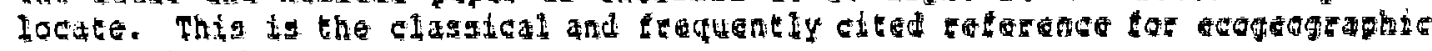
intoentition for oklahoma.

If you have any quegtiong. contact karolee owing at 918/581-7458.

Sinedety youtan

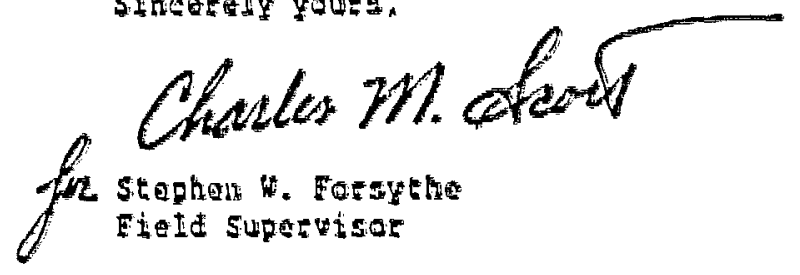

Enclogures

$450: d 6$ 


\section{United States Department of the Interior FISH AND WILDLIFE SERVICE \\ KANSAS STATE OFFICE \\ 315 HOUSTON SUTE E \\ MANEATTAN, KANSAS 6660\% \\ 9195393472}

December 23, 1994

Mr. Tony Policastro

Afgenne National Laboratory

9700 South Cass Avenue

Argonne, tlinois 60439

Dear Mz. Policastro:

This is in response to your recent telephone conversations with Dan Muthern of this office. and your December 9 facsimile transmission of data regarding the Radio Acoustie Sounder System (RASS) which is a part of your ovenall proposed weather fnonitoring, stations in Kansas and Oklahoma. The information you provided presented an etratuation of the potentiat effects of the RASS on migratory birds, and requested our review and analysis.

It is the opinion of this office that there is insufficient information atailable to adequately assess the potential for noise-related impacis on migratory birds or other wildlife spectes. Page 9 of the information you sent indicated the lack of literature on the elfects of sound on birds. Based on this, your information stated that anticipated effects carnot be quantifred at this time. The information you provided cifed potertial effects of loud noises on migratory birds, based on aircraft flyover studies and inferences from mignatory behavior. Such possible effects you proposed included disorientiktion to migming hirds, attraction to the locations of towers or guty wires, and disturbance to breeding birds to the extent they may abandon breding areats. We agree that at of these may or may not oceur. and there may be others as well. Sorte or all these possible effects may come under the juristiction of the taking provisions of the Migntory Bird Treaty Act (16 U.S.C.. 703 et seq.).

Bised on the uncertainty of how your proposed project may affect migntory birds. we are unable to concur with the determination that impacts ape "expected to be negligible". There must first be a more thorought evaluation of possistle effects. If data are not available from other simitar projects, consideration should be given to designing a study to simulate anticipated conditions and monitor the resulting effects on mignatory birds. The other alternative is to proceed with the project and risk a taking violation of the Migratory Bird Treally Act. 
Enclosed with this letter is a liating of the threatened, endangered, and category 2 sandidate bird species which may cecur in the three counties proposed to receive RAES facilities.

White there are many specieg of migratory bird not included in this ligt, it will give you an idea of where to start in an cvaluation of impacts. If you have additional quetions, please continue to direct them to Dan Mulhem. Thank you fot yout cooparation.

Enclosure

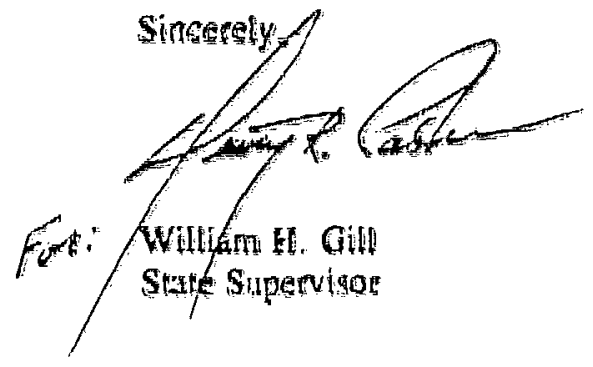

ce: FWS/FWE, Denve, CO (Section 7 Coordinator!

FWS/FWE, Gand Island, NE (Field Supervisor)

FWS/FWE, Tulsa, OK (Field Supervisor)

FWS/LE, Lene\%, KS (Special Agent)

KDWV. Prot. KS (Envifonmentil Sarvices)

DWM/WELG/dWm 


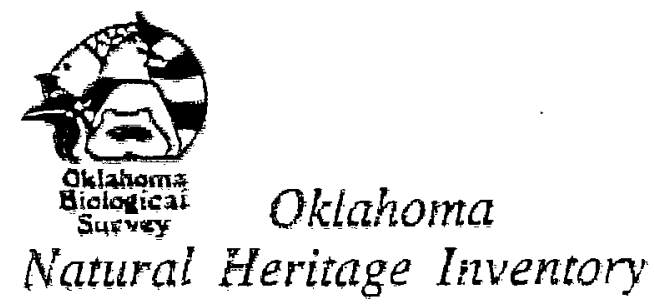

OKF.AHOMA GIOLOCICAL SJRVEY

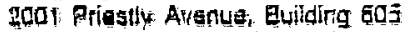

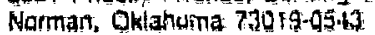

(405) $725 \times \div 965$

$44 \times 405$ : 375-7702

DATE: NON.21,19\%

REF:OTHEFFI $=339$

\section{Dear Sil/Madam:}

This letter is in resporse to your :equeat for information on posgible endangeted species of other elements of biotogical signilicatce at the site(s) indicated in your request of $11-18-1991$

The Qklahoma Natural Heritage Inventory maintains a database on the status and locavion of fare speciss and signifucant ecological communities in Oklahoma. We have reviewed the information currently in the Ferikage Inventory database and found no records of rate species or significunt corntrunites on or in the visinity of the site. Fletse tealize that the Nameal Heritage inventory has not conduted freld surveys of that speciffe site. One or more fietu surveys of the area would be reçuired to evaluate the specific site in derail.

The Hertiage Inventory database is the most current comprehensive one available on the pare biota of OkJahoma. However, such a database is only as complete as the information that has been collected. For this reason. we cannot state for cerwin whether or not a given sice harbors rape species or signidicant comnunities. We suggest you atso conuct the Environtrtental Division of the Oklahoma Department of Widdhe Conservation, as they may have site specific information of which we are unaware.

If we can be of any further assistance to you, plasse let ne know.

Sincerely,

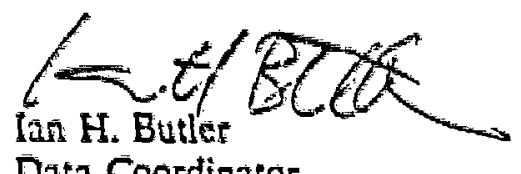

Data Coordinator 


\title{
Grant County Commissioners
}

Tat C. Martit

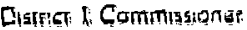

Shop Phone 405-59+2925

\author{
Room 104 Courthouse \\ Phone 405-395-2214 \\ Mradiond. Oklahoma 73759
}

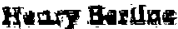

Distrci 2 Commisyongr.

Shap Rhene 405.395-2959

Juery if. Shattig?

Dighaf 3 Commishond:

Shop Fhond 405. F3? 6189

Carol Bagda, Boght4apar

December 2, 1991

lack PEingston

Argonne National Laboratory

9700 South Cass. Ave.

Butliding 900

Argorfe, flingig 60439

Dear Stra

In reference to Section 35. Township 25 North, 3 W.I.M. and Section 26. Township 25 North. 3 W.I.M. There are no land use restrictions on record in Grant County that nound affect the above figted propertieg.

BOARD OF COUNTY COMMLSTONERS

Geant County. Dletahema

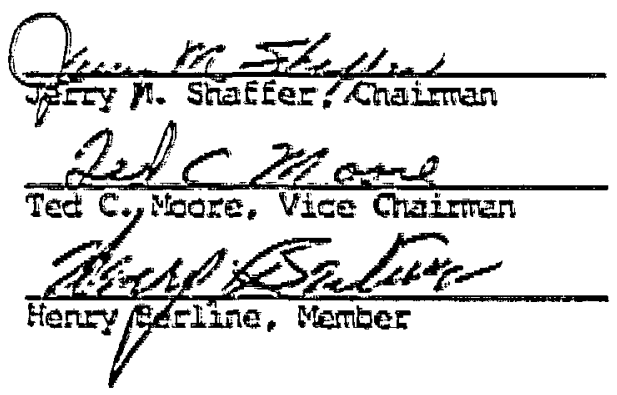


ROAFमT 4 KERR, JR

Chuiment

AILC, SECTEET

VleqChadrow

Q. G. JOHNSON

STot?

GERLYY BOFELL

TRANK H: CONDON

MIKE HENSOP.

RICHARD MCDONALO

EFUIN MIFCHELI

DICK SEYTOLT

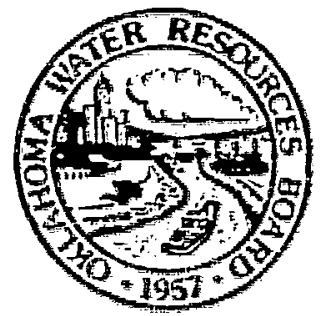

600 N. HARUEY AVE. P.0. 80X 150 OKLAHOMA CTN. OKLAHOMA $73101-0150$

November 19, 1994

Dr. Anthony J. Pollteastro

Envifonmental Assessment

Argenne National Laboratory

9700 South casa Avenlie

Argonne, If 60.439

Dear DE. "Poltcastro:

The floodplain information requested is enclosed. Some areas Fequested have never been mapped. The U.S. Army corps of Engineers may have some tata on these other areas. If necessary please call Mr. Joe Remondini in Tulsa at (919) 581-7896. If theze are any questione pleage contage Mr. Kan Morgis of the board's Engineering Diviston at (405) $231-2533$.

Sinceraly.

Wh Woins - for

Harold L. Springes, P.E.

Chief, Engiteering Division

wkm

Enelosures 
UNITED STATES DEPARTMENT OF AGRICULTURE
SOIL CONSERVATION SERVTCE
ORMULGEE EIELD OFFICE 219 EAST 8TH STREET ORMUEGEE, ORLAHOMA

Subject: Resouree Aralysis

Sh I/4 Section I. THSM, RISE

Qate: Movenber 21, 1991

SE $1 / 4$ section 2. TI5M, RI4E

SE $1 / 4$ section 35, TIEN, R14E

NE $1 / 4$ section 3 , T15M, RIAE

To: Hr. Anthony J. Polocastro and Jack péfingston

Hegonne Mational Laboratory

9700 South fags Aventie

Argonne, Ilifnois 60439

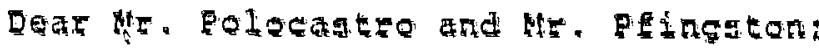

Eflolesed are two mapg of the above legal deserintions. Thr soils magl which are deisneated with solid and dashot Iines, depict the majer soil series in this area. There is eurpentiy no active tring in these areas. The "Vg" Verdigris soil gerieg ig a prime farmand soil type. It is Eound only in SE $1 / 4$ of Section 35, T1GN, RIAE. Your propoged projact ul not have a dotrimantal impace on the

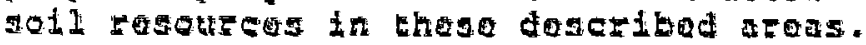

The SCS weland maps indicate no wetand or hidtic soils in any of the deseribed areas. The USDI Fish and Widdi Service Mational Hetiant inventory mape indicete a palustrine ecological systen, torested wetland in tha "Bu" Eroken AIIuvial soli tupg in section 35 TIEN. RIAE. This area does not med the past or the curtent wetland agtinition. I ean ascozedit no long torn detrimantil impact

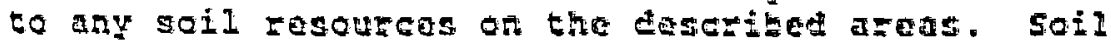
Aisturbance of loss due to any congtzuction can be menafod effectively with simple orosion contyat technigues. IE you nood further information on this subject. please lat me know.

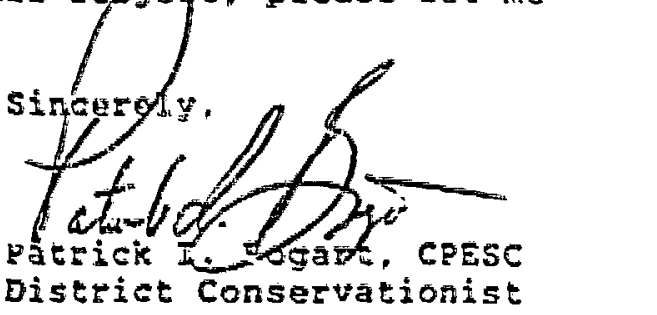


November $27,199:$

Dr. Arehony J. Pollcastro

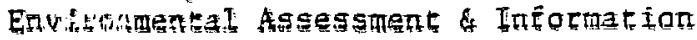
Sciences Diviston

Argonne Natonat Labotacery

9700 Squth Cags dvenue

Argonne, T114nots 60439:

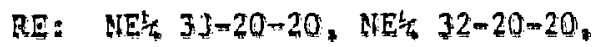

Deare Str: MN/ 3I-20-20, Woodward Councy

Wetlanda mapg and floodplatn maps have been checked on all three proposed locations in Woodward County and none of them have verllands or are tn a fleodplath.

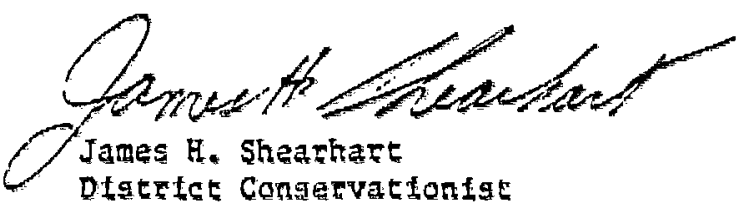


Dr. Anthony 3. Polledstro

Argonne National Laboratory

9700 South Cass Avenue

Argonne, Iltingis 60439:

Dear Or. Policastro:

This information is provtdegd to your request of a letter dated November 20, 1991 destring some data on three eracts of land located to Grant County. Oklahoma. The following tracts are described as:

SW/4 Section 35-T25H-R3W

NE/4 Section 35-T25N-R3W

SE/4 Section 26-T25M-R3W

I have completed a study of the USDA Sail conservation Servise and the US Fish \& wildife maps concerting fdentified wetlands on the above mentioned tracts. The maps indicate the only areas of impounded water on these tracts are man made ponds and are not subfect to the wethand provisions. There are no true identifted wetiands on these traes.

In addition, none of these tracts are located in a flood platin area.

If you need any further information, feel free to contact our office.

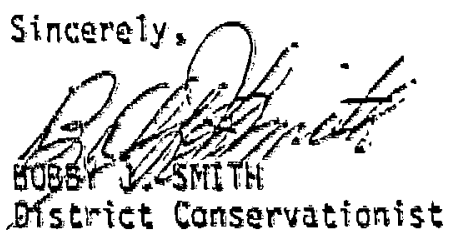


December 6, 1991

De. Anthony J. Polfcastro

Envf tondental Assessmequ \& InFormaton

Sctences Dfuls fort

Aegonne Natgonal Latofatrofy

9700 South Cags Aventye

Asgonne. IIItrofo 64039

Dear S.E:

Re: $H E^{2} 33-20-20 ;$ N $32-20-20$; NW 33-20-20, Hoodwasd Couney

WeElands maps and floodplatn mapo have been checked on all three proposed Iocafons the Hodward County and nome of ehem have vethands or aze In a tededpiata.

The NEt Saction $33-20-20$ and the Net Saction 32-20-20 to not conteata

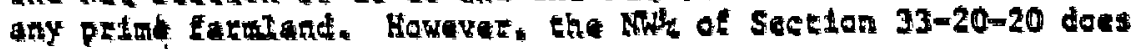
conteath pretue faruliand.

Sincerely.

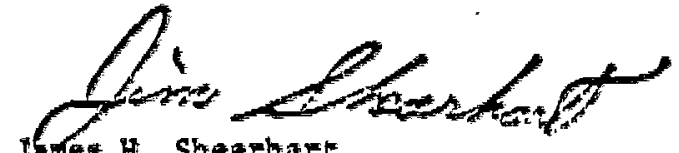

ISHes H. Sheachate

Distekes Conservationige 


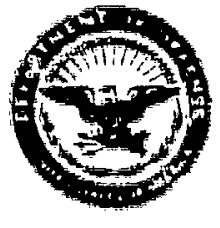

FEP $F$

ATTENTIM DF

\section{DEPARTMENT OF THE ARMY}

TULSA DISTAICT, CORPS OF ENGINEEAS

PQST OFFICE BOX

TULSA, OKLAHQMA T\$121-QOOG:

January 29, 1992

Planning Division

Genaral Planning Branch

Anthony I. Policastro, Ph.D.

Environmental Assessment and

Information sciences Division

Argonne National Laboratory

9700 South Casg Avenue

Argonne, IL 60439

Dear Dr. Poltcagero:

This la in further regonge to your Hovambar 20, 1991 , lotege and our December 13, 1991, Eesponje conedrning loodplain and watland designatlons for several sections in crant, Meclain, okmulgee, and Woodward Counties in oklahoma and kfowa, Marfon, and Montgomery counties in kansas. An ofticial recelpt will be forwarded to you upon receipt of your $\$ 75.00$ check.

The fol.howing table indfeateg the typo of information available for each requested county. If offlelal Federal Emergency Management Agency Flood Inouranec Rato Maps do not exist, UsGs tlood prone area mapg waso consulted. Whare information is avaliabla, coptes of the maps with areas fndicated have been supplied.

If you have any fusther questions, please contagt Mr. Joe Remondini at (918) 581-7896.

sincerely,

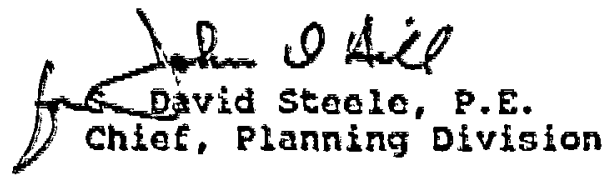

Enelosures 
Mir. Jack Pfting tien

Environmental Assessment and Informatiton Sctences Olukision

Argone Nath fond Laboratory

g7oo: South Cass Avenue

Argone, Itithola 60439

Dear Mr. Pfingtton:

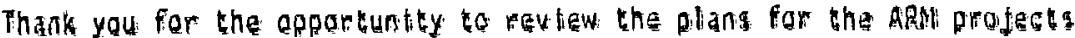
tn Marion and Montgomeary. Gountíg

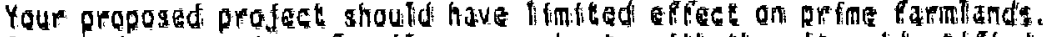

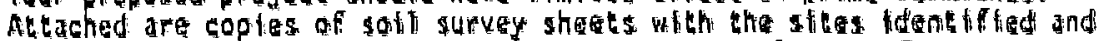
a list of prime farmiands to thesa areas. Qurting layout of your project it is best to avold these orfme farmilands. If you are undote to awotd the prime formiands. a farmiand Conversion tmpact bating (foutm A0-1006) is required for the spactfic stitas.

Conetdarations should te madia for tha numerous conservation practlecs

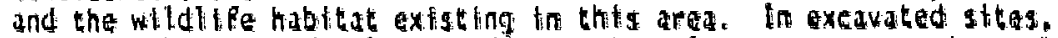
backilli should be firinly packed. We strongly oncourd do you to wark

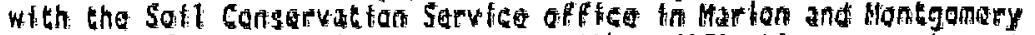

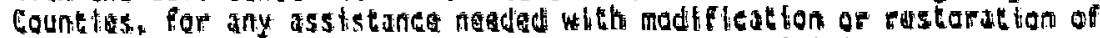

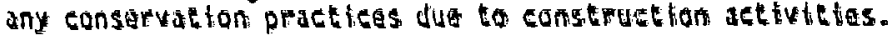

Please furnish these offtees a detatled map of the In: atlation once th is installed. This witl ensure that fulure conservat fon detwity witl nok jeopaedize your tontalliation.

Sincerely.

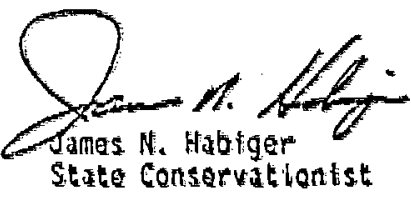

Athathments

ce: w/o atcathinents

11. Lym Glosen, Area Conservationist, SCS, Emporta, xS Gary Sehuter, disketek Conservationist, SCS. Marton, KS

Sodt Cusherbery, Qistriet Conservationtst, SCS, tndependence. ks 


\section{Appendix E}

Evaluation of Nolse impacts of the 50- $\mathrm{MHz}$ and $915-\mathrm{MHz}$ Proflter/RASSs 
E-2 


\section{Appendix E}

\section{Evaluation of Noise Impacts of the 50-MHz and 915-MHz ProtileriRASSs}

\section{E.1 Introduction}

This appontix summarizes the methodohgy used to fetermine the potental impacts on people trom noise areated by the bafled $50 \mathrm{MGl}$, the unbathed $56-\mathrm{MHz}$ and the $9 \mathrm{H}-\mathrm{MHz}$

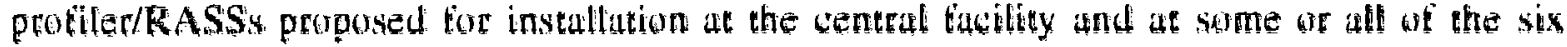

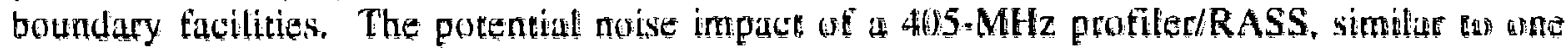

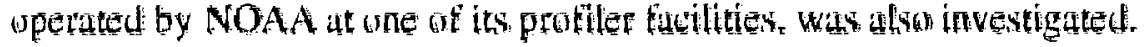

In ofder to clarify this appendix and Sectiont 2.4 and 3.4 wf the text. is tew of the tems and conventions that are used shall be discussed. A given frequency bund re ters to the corresponding

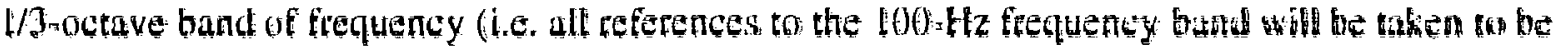

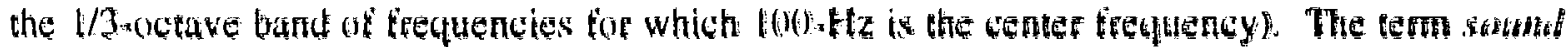

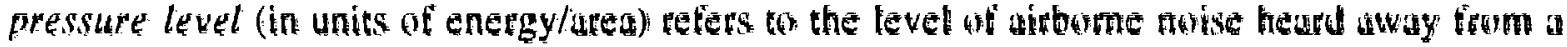

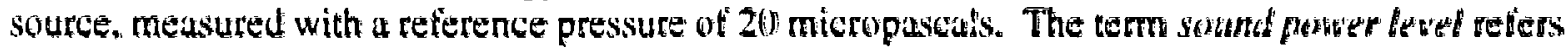
to the acoustic power (in units of enegy) of the source. measured with a deterence power of 1 picowatt. Finally, all sound pressure tevels are unweighted measuraments.

Alt four profiler/RASSs cmit tonat notse. White white nutse (notse trom a combination of

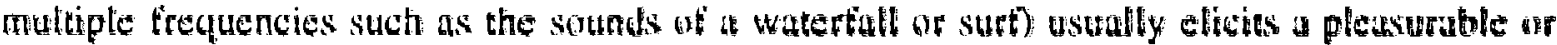

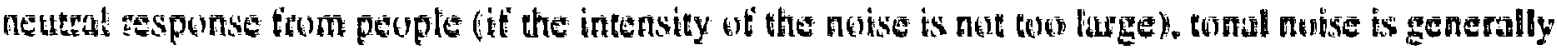
annoying th human beings. The sound made by these grothter/RASSs is an eniled tone that lasts tor about 5-6 min every halt heur.

The toghonn-like sound of both the batted and unbathed 50-MHz protifer:RASSs is a

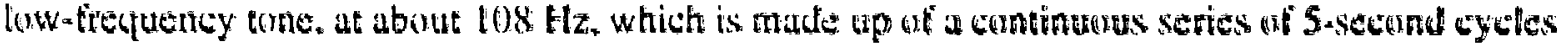
(during which time the noise varies slightly in lequency. centered around the $10(\mathrm{n}) \mathrm{Hz}$ trequengy

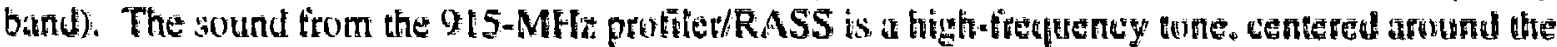

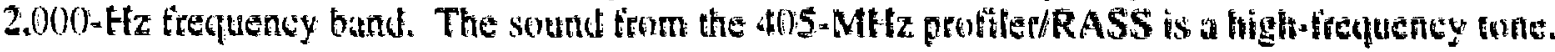

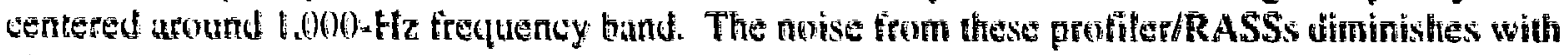

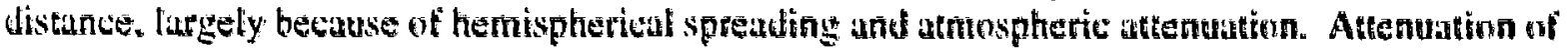

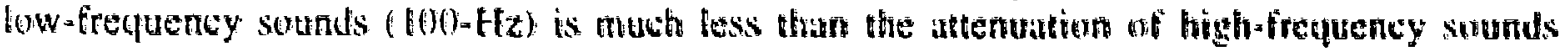
$(1.000) \mathrm{Hz}$ and $2.00(\mathrm{~Hz})$.

The question to be answered is whether these protiter/RASSs would be anmoying to the residents of the neurby houses. Besides the intensity of the noise source. the distance tutween the source and the receptor (the closest residence) and the background ambient noise le:-el are important tor determining the noise level and the potentisl annuyatce. Therefore. a determination must be thade as to whether the proposed distunces between the protiler/RASSs and the nearest tesidences are lufge encugh to achice sutfictent attenuation. The analysis described below is based on the asstmption that the resifents are outdooss and on their property. cinse to their homes. 
The strueture of a house reduces the noise tevel of a sound by about 21-25 dB when windows ure closed and by about 12-15 dB when the windows are open. Four protiler/RASSs are stutied here: (1) the unbaftled 50-MFiz protiler/RASS, (2) the 915-MHz protiler/RASS, (3) the bafited $50-\mathrm{MHz}$ protiler/RASS, and (4) the 405-MHz profiler/RASS.

The predictive procedure for noise impacts follows tive main steps:

1. Measurement of the sound pressure l:vel of the (unbafflet) $50-\mathrm{MHz}$ protter/RASS and the 40S-MHz protilev/RASS. Note that sound pressure with

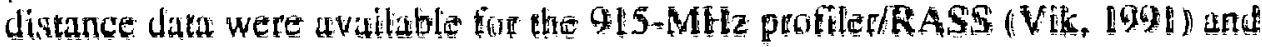
sound pressure level with distance dista were not requited for the bafflet 50-MHz protiler/RASS since it suld be determined term the mewured unbatfled 50-MElz protiler/RASS.

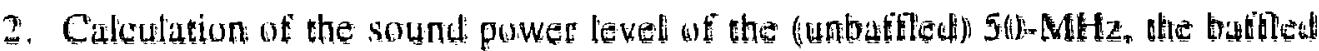
50-Mitzo the 405-MEtz, and the 915-Mtz profiter/RASSs.

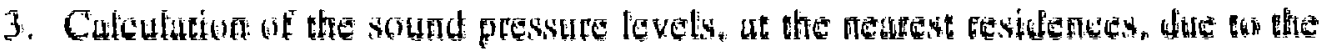

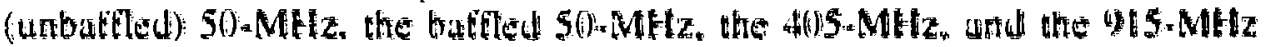
prohiler/RASSs.

4. Measurement of the residud umbient environmentul noise level at the mearest residence for each possible siting of a protiler/RASS. Nuise levels in each firequency band of interest ate required. This step includes medsurements or reliable estimates at the propresed site und the two to three altemative sites for eacte of the eentral tactlity and the six butndiry tucilities.

5. Prediteton of the impate of the nuise enissien them the profiler/RASSs at eath of the focations mentioned in step 2. Two ntethords are used bon assess the impacts af the noise ersission. Fiest a mofitication of the Compasite Nonse Rating (CNR) methed (EET. 1984) that categhizes noxise from " $A$ " to "f." These designations, in tarn. can be cortefated to the expected degree of community reaction. Second, a method developed by Fidell (Fidell. ef all. 1982: Fidell. et al. 1087: Fidell. st al. 1988) is used to categentize the impats in terms of the probubility of an individtut constudering the notse as not at all

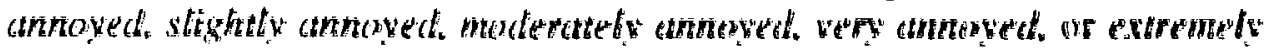
unnowere

\section{E.2 Measurement of the Sound Pressure Level of the Unbattled $50-\mathrm{MHz}$ and the 405-MHz Profller/aAsss}

Sourd pressure level measurements on the $5 \%-\mathrm{MHz}$ and the $4015-\mathrm{MHz}$ profiler/RASSs that are located at Coffeyville. Kansas were made by Argonne personnel on November 29. December $6.199 \%$. with a Bruel and Kjaer sound level meter Model 2351S. A 1/3-nctave band fitter set was used with a $l-i n$. microphone and a $5-\mathrm{cm}$ windscreen. A portable Zenith PC 
somputer was used to control the sound level meter, allowing measurements in the $100 \mathrm{~Hz}$ trequency band (for the 50-MHz profiler/RASS) and in the 1,000-Hz frequency band (for the +05-ME(z protiler/RASS) and recording sound pressure levels taken during l-s samples, By using the stow (Jetection time constant) setting. The ontputer controlled the sound level meter signal output by filtering sucessive $1 / 3$-octave bands for 30-s intervals over a total measurement period of $13.5 \mathrm{~min}$. The ambient noise was sufficiently steidy tw allow this to be done in one lo th 15-min period.

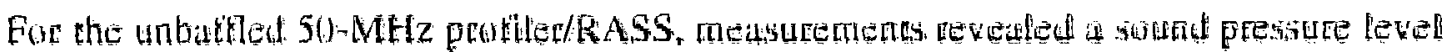

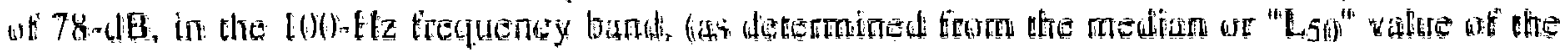

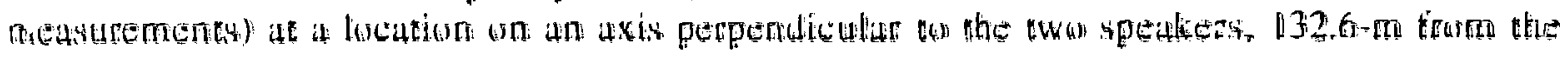
centerot of that axis.

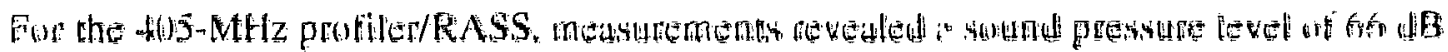

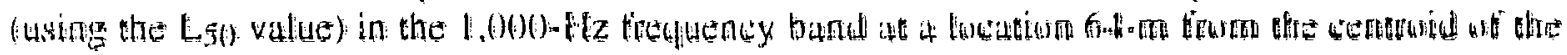
tour-spederen system.

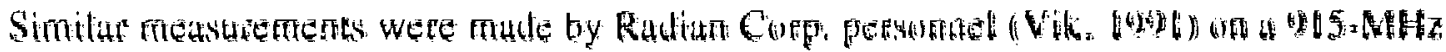

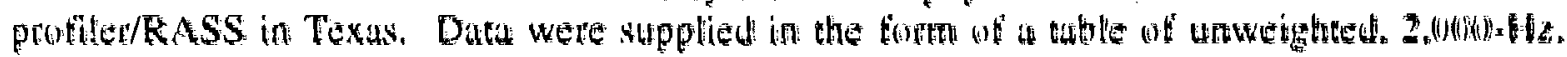

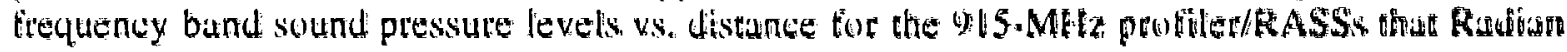

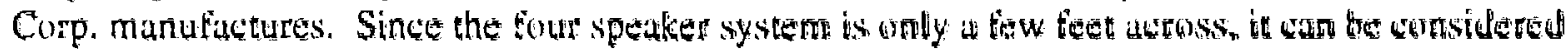

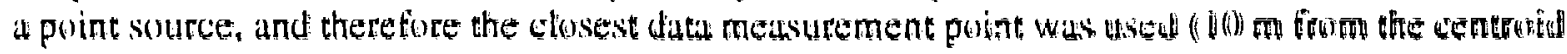

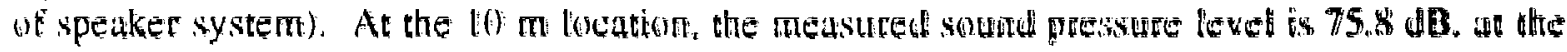
2., (1)(1). ftz trequency band.

\section{E.3 Calculation of the Sound Power Loval of the Battled $50-M H z$, the Unbaffied $50-M H z$, and the $915-M H z$ and $405-M H z$ Profller/RASSs}

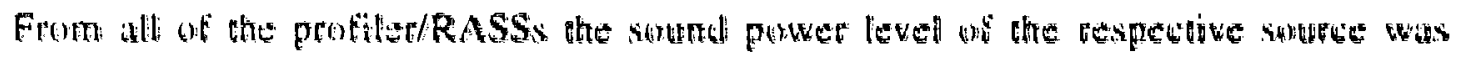

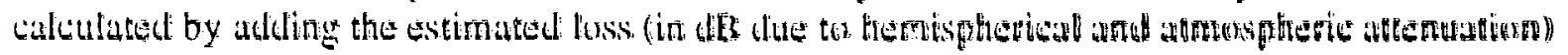

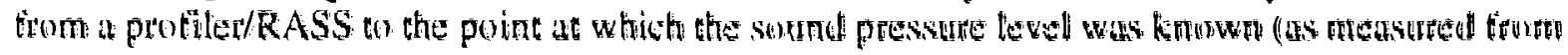

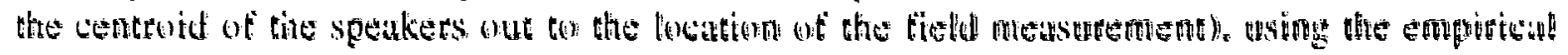

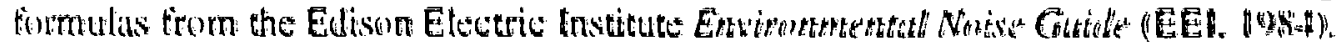

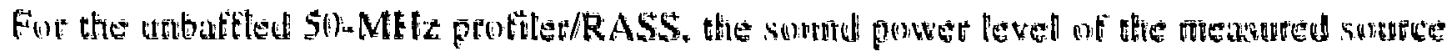

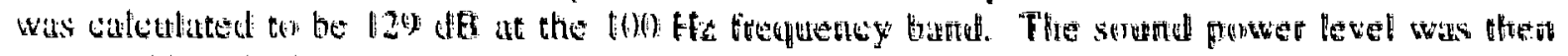

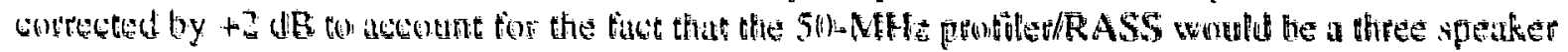
system tather than the twa speaker system that was meastred. Therebore. the extimated sobnt

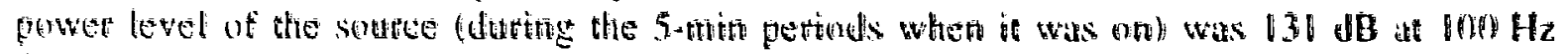

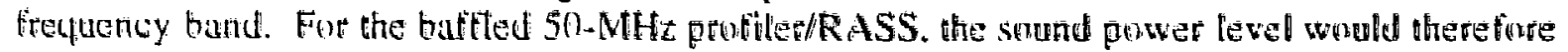

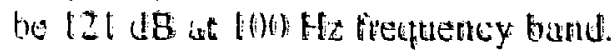

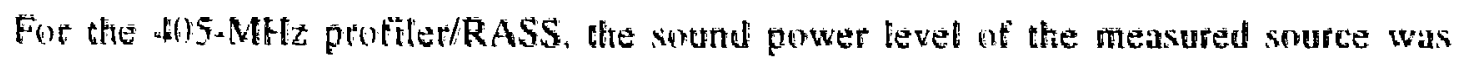

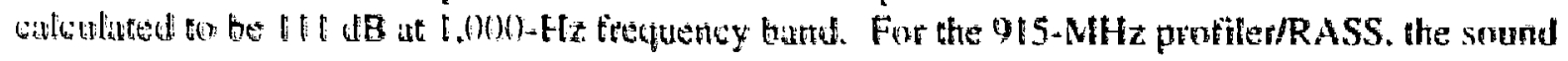


power level of the sour was calculated to be $104 \mathrm{~dB}$ at $2,000-\mathrm{Hz}$ frequ- zy band. Table E.l summarizes the sound pow if tevels of the various profiler/RASSs.

\section{E.4 Calculation of the Sound Pressure bevel at the Residences Nearest Potental Locations tor the Batfled $50-M \mathrm{~Hz}$, Unbattled $50-\mathrm{MHz}$, 915-MHz, and 405-MHz Profiler/RASSs}

Given the ambient sound power level of the profter/RASSs, the sound pressure level at the mearest residences trom these protiler/RASSs was calculated. The smont pressure level was determined by subtracting the eximated loss (in dB due to hemispherical and atmospherio atenuation) tion the profiler/RASS; (with known sound power level) to the varibus residences (at known distances from the potential grotiler/RASSs), using the empirical formulas from the Eulsum Electric Institute Environmentul Noise Guicle (EEL. 1984). Figure E.I gives the soumd pressure

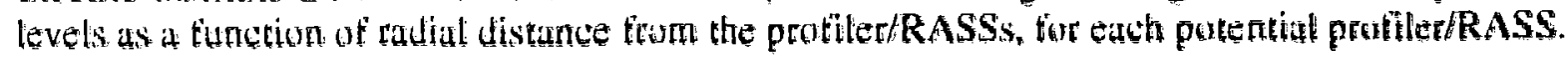
Note how the low-fiequency sounds attenute less with distante than don high-frequency sunds.

\section{E.5 Measurement of Background Ambient Noise Levels at the Residences Nearest Potential Lecations for the $50-M H z_{z}, 915-M H z_{b}$ and 405-MHz ProtherfaAss}

Sound pressure level medsurementis were made at the neurest residence of several of ofe possible site locations tor the 50\% MHz, $15 \times$ MHz. and 405-MHz profuler RASSs The proturent for the measurements included the following regutements:

1. Wind speeds were to bo low. i.e.. under 5 mph (or 5*16) mph if that were nut possible) sat that the wind-induced ateise an the microphone screcn would be much lower than the background noise level being measured.

2. Measurements were to be taken in the late evening or at nightime (between 10. p.m. of 6 a.m.) to cover the period when residents are mest sensitive to the noise (i.e. when they are sleeping or are attempting to fall asleept. At thuse

Tatie E.: Sound Pawer Laval of the Various rotiler/AASSS

\begin{tabular}{|c|c|}
\hline ProtilarffASSS & Sound Powet Level (dis) \\
\hline Eathed $50 \cdot M H z$ & 121 \\
\hline Unbatfled) 50-MHz & 131 \\
\hline $405-M H z$ & 111 \\
\hline $915-\mathrm{MHZ}$ & 104 \\
\hline
\end{tabular}




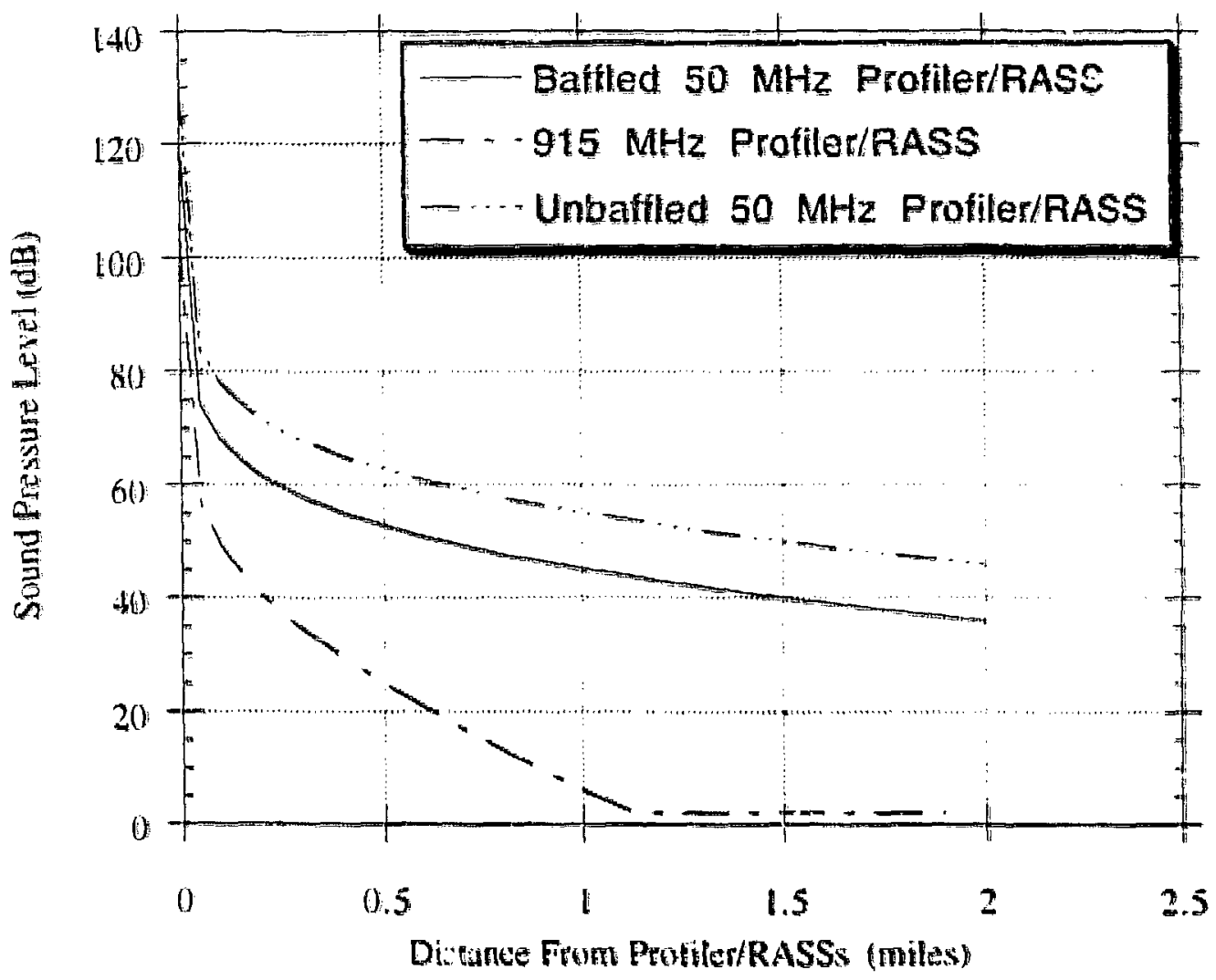

Figure E. Decay of Sound Pressure Level with Distance tor the Proftlew/AASSs

times, the background noise level (and ambient surtace winds) are likely to be at their lowest level for the day.

3. Measurements were to be taken at the closest public property (generally a rural road right-of-way) a(jacent to the tract of land that contains the residence. The precise focation would be chosen to avoid sound retlections from the nearby home.

4. Measurements were to be taken during a 2-hour period and would include sound pressure level data on the full $1 / 3$-actuve band spectrum and a 30-min. time series of data in the $100-\mathrm{Hz}$. $\mathrm{E}, 0001-\mathrm{Hz}$, and 2,000$)-\mathrm{Hz}$ frequency bands. The sound levels in each frequency band were expected to be rather steady. allowing measurements over this period to be representative of lonper medstrement times.

Background data were collected at five residences. Because of the difficulty of collecting reliable data (mostly beciause of high wind speeds), the $\mathrm{L}_{90}$ values were determined from the best fata set. because the noise environments appeared to be similar at all of the residences (L9n 
represents the sound pressure level that is exceeded by $90 \%$ of the measured data). Table E.2 lists the residual ambient noise levels for each frequency band of interest. These data were used in the subsequent calculations of the sound pressure levels in the $100-\mathrm{Hz}, 1,000-\mathrm{Hz}$, and $2,000-\mathrm{Hz}$ trequency bands at each residence. Figure $\mathrm{E} .2$ is a sample histogfam of the $100-\mathrm{Hz}$ frequency band ambient noise level measured at the Montgomery County. Kansas, boundary site, indicating that the Lon value is $30 \mathrm{~dB}$.

\section{E.6 Prediction of the Human Reaction at the Residence Nearest the Operation of the $50-M H z$ and $915-M H z$ ProtileriRASSs}

In th is EA, two methods are used to assess the effects of the noise on the people an the Fesidences near the profiler/RASSs: (1) the muditied Community Noise Response (CNR) moded (EE! 1984) and (2) a method by Fidetl (Fidelt et int. 1982; Fidell et al.. 1987: Fidell et at.. 1988), which is composed of the Probabilistic Noise Audibiliny (PNA) model and the Individuat Annoyance Prediction (IAP) mudel. A brief disctssion of these methods is given here.

\section{E.6.1 The Modifted GNR Method}

The modified CNR method (EE: 1984) is the method most accepted for predicting community reaction by the power industry for fixed. continunus noise sources. The protiler/RASSs qualify as eontinuous sound sources. and the methodology is applicable. The method is based on empirical data token trom social surveys of annoyance due to fixed noise sources. Data used in the method inctude the following:

1. The sound pressure levels of the intrusive noise at the residence location and the environmental background noise levels.

2. The character of the noise source (such as whether it is of very low trequency or of tonal character) and also its intermittence (ratio of the source's on time to a reference time period of. say. $1 \mathrm{~h}$ ). Included also are seasonal (winter. summer) (operation and other temporal factors (daytime or nighttime only).

Table E.2 Measured Ambient Noisa Leveals Used in Modeling of Protiler/RAsS Noise Impacts

\begin{tabular}{cc}
\hline Frequency Band $(H z)$ & LgoldB) \\
\hline & 30 \\
100 & $1 \hat{0}$ \\
1,000 & 8 \\
2,000 & \\
\hline
\end{tabular}




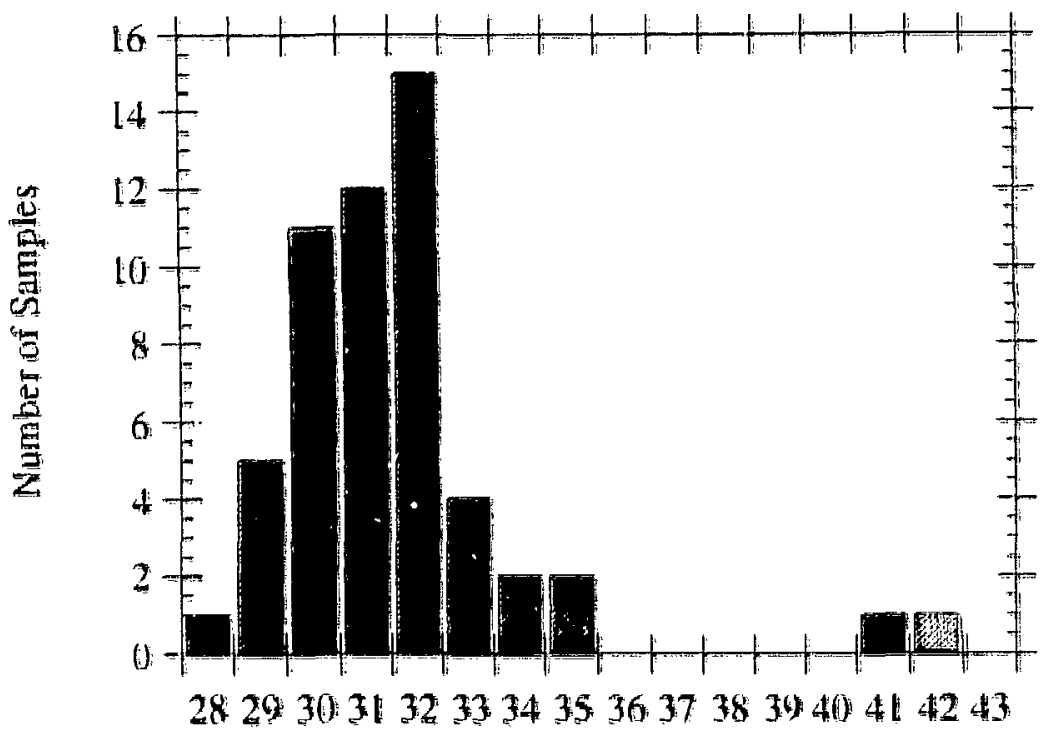

Sound P(wer Level Meistrements (tub)

Figure E.2 Histogram of Sound Fressure Level Measuraments

3. Subjective factors steh as the previous exposure history of the community to that noise source and the commonity attietde.

The moditied CNR method categorizes noise from $A$ ar 1 . These designations, in tum. can be correlated to the expected community reation. Figure E.3 gives the range of community reaction for the various composite noise ratings.

\section{E.6.2 Fidall's Mtathod (PNA/IAP Motols)}

The second model of human annoyance that was used is the psychoacoustic model of Fideil (1987, 1988). This mudel was used as a supplement to the modified CNR findings, in order to verify that sites deternined by the CNR model would also be acceptable by this model. The Fidell model, a new and different type of computer model, was also applied to the issue of siting the profiler/RASSs. Fidell and Teffeteller (1971) demonstrated that test subjects engaged in an attention-demanding toreground task did not report noticing intruding sounds until the sourds had a considerably higher signal-to-noise ratio than would be requited for detection in a deliberate listening task. The inteinsity of subsequent annoyance judgments made by test subjects after the presence of an intruding noise was noted (but while the subjects were still engaged in an absorbing foreground task) was directly proportional to the detectability of the intruding sounds ( $\mathrm{dB}$ above masking level). Figure E.4. adupted from Fidell and Teffeteller. displays this relationship. 


\section{COMMUNITY REACTION}

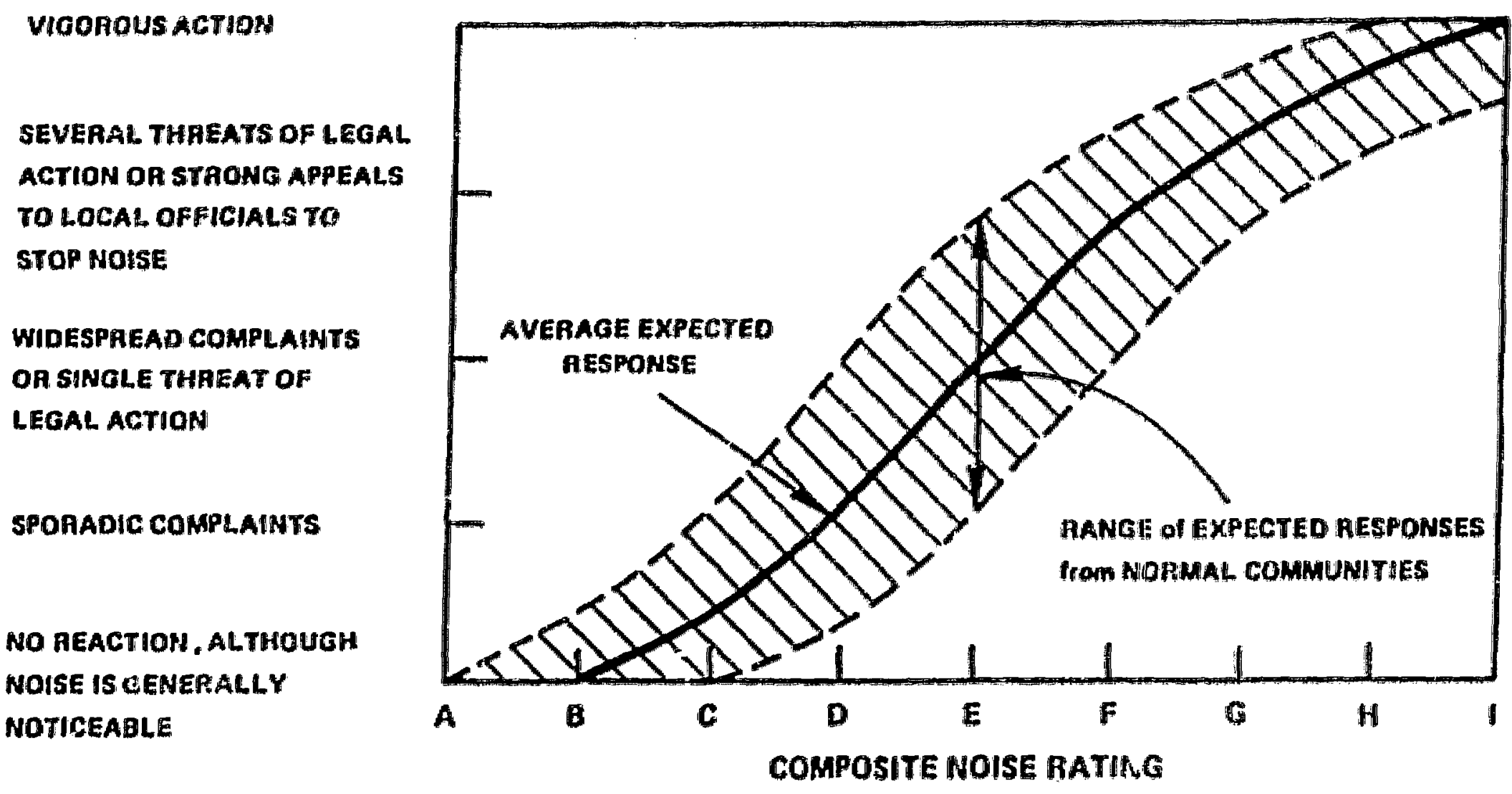

Figure E.3 Estimated Communily Response vs. Composite Moise Aaling - Modined CNR Model fReproduced by permission of Edison Eloctric Insitute, Washington, D.C.) 


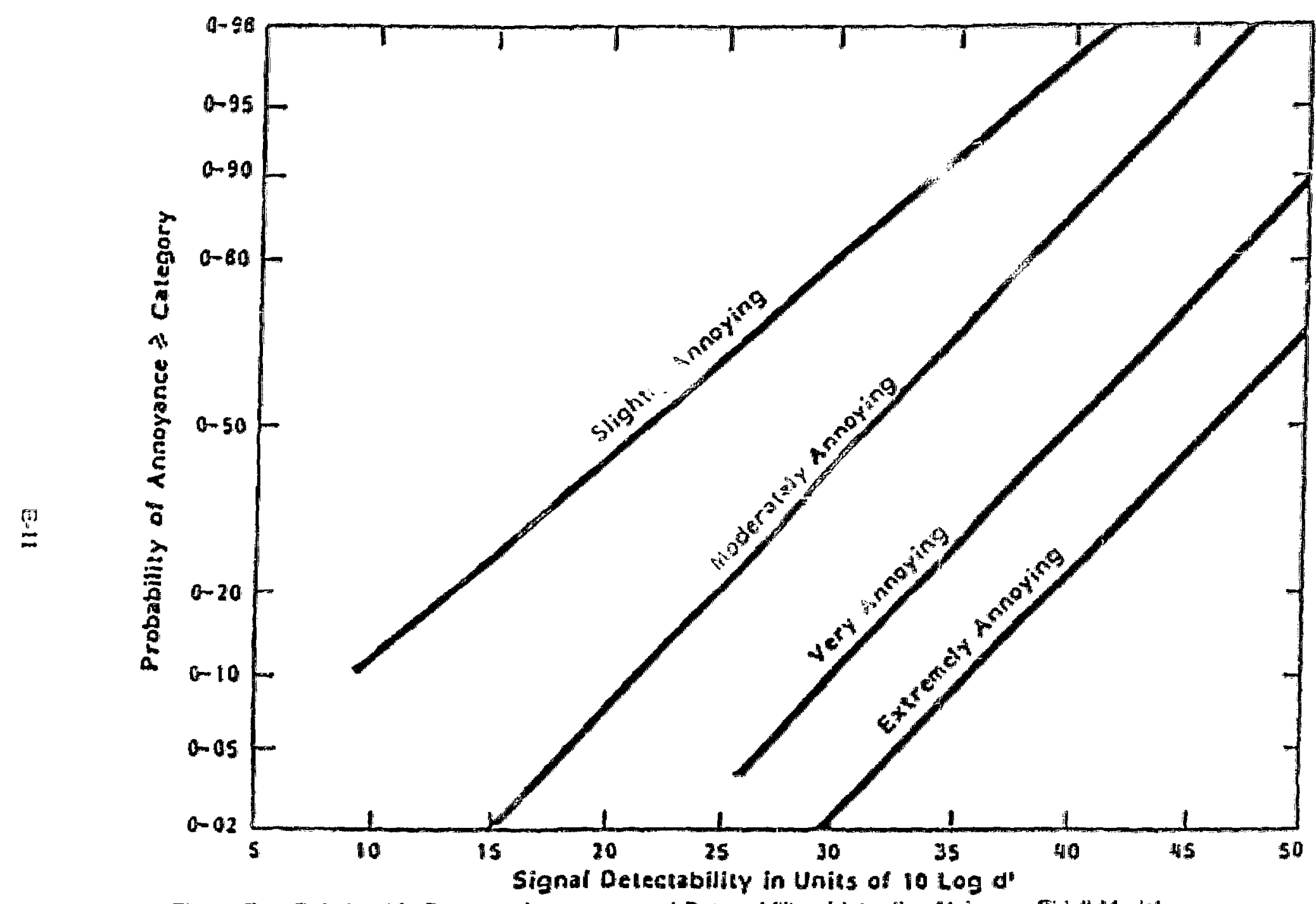

Figute E.4 Relationship Between Annoyance and Delectability of Intuding Noises -- Fidell Model 
Half of the subjects engaged in an absorbing foreground task first noticed an intruding sound when it attained a signat-to-noise ratio characterized by a value of $10 \log \mathrm{d} "=1 \mathrm{AdB}$. People not preoccupied in a tusk can reliably distinguish a signal from noise when its detectability attains a value of $\mathrm{d}^{\prime}=1$ of $10 \mathrm{log} \mathrm{d}^{\prime}=0$. Pearsons, et at. (1979) tound that subjects first nutied an intruding sound for which they were not specificully listening at a value of $d^{\prime \prime}=2.3$ or lo log $d^{\prime \prime}$ $=4 \mathrm{~dB}$. The difference in results reported by Fidell and Teffeteller and by Pearsons et al (1979) suggests that an absorbing task can have in effect of about I0 dB on the way people jutge intruding sounds.

These data let to the inference that the level of detectability of an intruding sound (d") must be three orders of magnitude (30) (1B) greater than the butely andible level before $50 \%$ ut the subjects, engaged in activities wher than listening tor the swund, are moderately annwyed. The whtis

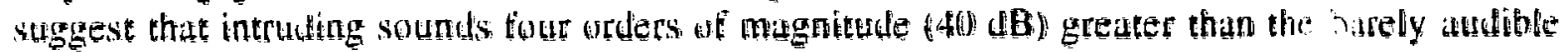
level are required betore hall the subjects become extremely annoyed.

Since 1971. Fidell and o thers bave been investigating probabilistic th. dels bor preficting the audibility level of an intrusive nosise in the presence of a background mosking novise, wn the

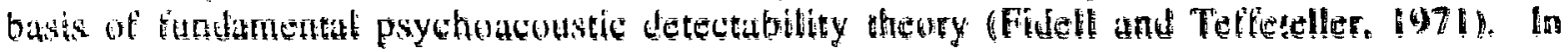
addition, corollary research hus progressed on the relationship between the atubibility level and its annoyance to an intividual. This research has been supported by the U.S. Envirotonental Protection Agency, the U.S. Air Force, the U.S. Army, and the Electric Power Research Institute. This extensive program (including the data described abeve) has led to the bevelopment of probabilistic modets for predicting the tollowing:

1. The detectability and atudibitity of an intrusive nerise in the presente of a snasking background sound (PNA monden)

2. The level of individual innoyance cansed by that intrusive noise. taking into arcount certain nonacoustic variables involved (iAP molel)

Because no field verification studies are yet avaiboble fir the IAP model, that methudology must stitl he considered to be in the research phase. and the sponsoring agencies listed above withhold unquaitied endorsement until tield testing can be arcomplished. Nevertheless, because veriftution is likely to be achieved in the foreseeable future and besause it is more advanced scientifically than the modified CNR metherdology. the PNA-IAP paired models have been included in this study.

The first step in the procedure is te use as input to the PNA model both the baseline environmental ambient Log spectrum and the predicted profiler/RASS intrusi ie noise spectrum (resulting from sound propagation and atmospheric attenution) at the reside ite. These values determine the audibility of the intrusive noise. expressed as an intrusion level in $\mathrm{JB}$. for a s secified detection etfictency and a nominal $50 \%$ probability of detection by the listener (ar's a $1 \%$ probability of talse detection). The second step is to assign the following psychological factors sor the inclividual who is assumed to typify the resident: affected state. concentration. and Bayesian 
criterion, which coltectively determine a tolerance index and a decision criterion index, all in $\mathrm{dB}$ units. The relationship between these subjective indices is as follows:

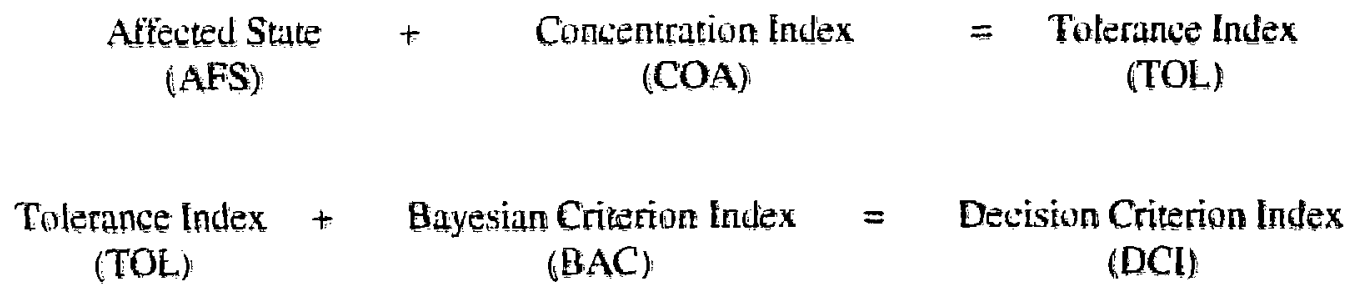

The IAP mudet uses the above dua for the protiter/RASS noise to predict the must

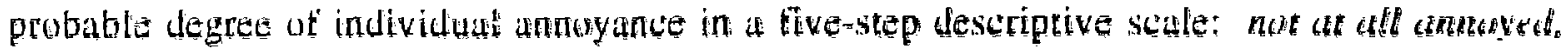
sitghtly annoyed, moderately annowed, very annowed. and extremely annowed. These terms are

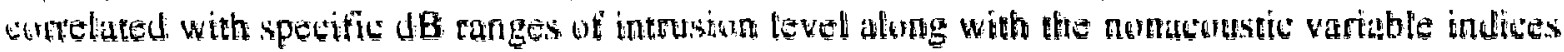
selected as appropriate for rural residents.

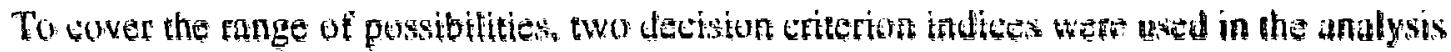

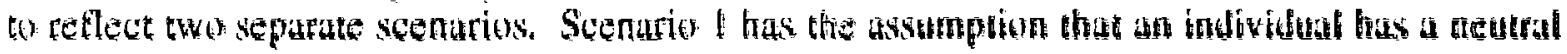
attitude toward the ARM Progrom and is not soncentrating on any specific task. ?eading to a tolerance index of 0 . Scenario 2 has the assumption that an individual has a positive attitude toward the ARM Program and is concentrating om a specific task. leading to a tolenance index of + 10). Fidell has recommended, until better dati are available, that the Bayesian criterion be set to zero.

The steps required tor calculating of the le vel of noise impacts at the pesidence nearest a protiler/RASS tunbalted 50-MHz. 915-MHz. 50-MHz battled. or 4(5)-MHz) is as tollows:

1. Predict the propagation off the noise feom the protilet/RASSs to the nearest restdences. assuming standard day conditions $(5)^{\circ} \mathrm{F} .70 \%$ relative humidity) with no wind. The propagation tormukas and tables presented in the Edison Electric Institute Environmentul Neriste Guifte (EEI. 1984) were used for this purpese. Predictions had to be made anly tor the 1/3-octave band in which the noise occurs: background noise from the other 1/3-nctave bands cannot mask

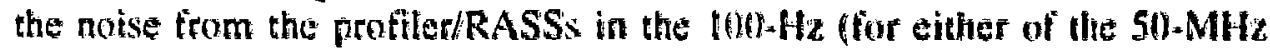
profiler/RASSs). 2.00kt+Hz (tor the $915 \cdot \mathrm{MHz}$ profilez/RASS). of $1.00 \mathrm{H} \cdot \mathrm{Hz}$ (tot the 405-MHz profiler/RASS) frequency bands.

2. Fitura the background ambient meastrements. determine the masking level for the $1 / 3$-0stave band of interest by adding $2.2 \mathrm{~dB}$ to the $100-\mathrm{Hz}$-band ambient tevel. adding $4.6 \mathrm{~dB}$ to the $1.0010-\mathrm{Hz}$-band ambient level, or adding $-5.5 \mathrm{~dB}$ to the 2.000-Hz-band ambient levels. If the resulting masking level is below the theshold of hestring, the threshoid of hearing is used instead. That threshold is $30 \mathrm{~dB}$ at the $100-\mathrm{Hz} / / 3$-netave band. $6 \mathrm{~dB}$ at the $1.000-\mathrm{Hz} / / 3$-octave banc! and $3 \mathrm{~dB}$ at the $2.000-\mathrm{Hz} / / 3$-octave band. 
3. From the residual ambient noise level and the propagated noise from the profiler/RASSs in the $100-\mathrm{Hz}, 1,000-\mathrm{Hz}$, or $2,000-\mathrm{Hz}$ //3-octave bands and the tolerance indices of both $\theta$ and +10 , use the IAP code to determine the predicted response of the residents. The predictions afe in terms of levels of annoyance.

\section{E.6.3 Rasults}

Tables E.3.E.10 summarize the predictions of the roditied CNR method and the Fidell methurl (tog tolerance indices and decision criterion indices of 6 and 10 ) for the propused action

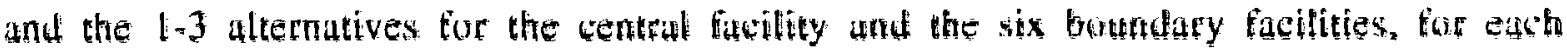
protiler/RASS of interest. Differences umong the teactions festlt from the difierent distunces uf the residences from the profiler/RASSs.

A point of explanation is needed eoncenting the Fidell modet results presented in Tables E.3-E. 10. The raw output of the Fidell madel is in tems of cumulutive probabilities of annoyance (nok presented here), while in Tables E. 3-E. H the Fidell tesults are in levels of annoyance. The levets of annoyste presented ure the lowest levels of annongnce associded with at least a $50 \%$ cumulative probability (which are the most likely levels ot annoyance of the individual). For example the level of anroyance for the Kiowa County boundary fucitity alternative 2 (moderately annoyed) listed in Table E.6 was determined from the cumulative probabilities presented Figure E.S. Note that level of unnoyance is the lowest level of annoyante

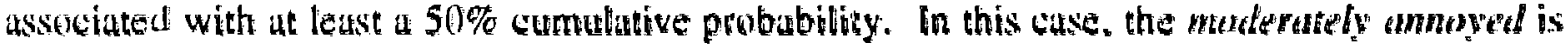
astociated with a curtutative probability of $63.4 \%$.

The cummonly-used criterion for atceptability of noise impases is commoniry rederion A. B. of $\mathrm{C}$ as defined by the moditied CNR method. Under the modifted CNR criterion. the profiler/RASSs are acceptable at the locations insticated in Table E.15. Only tre central fucility (proposed site and alternatives) is acceptable tor the unbatted 50-MHz profilet/RASS, becouse of the relatively large distunce between the site of the protiter/RASS and the residences nearest the centrat facility. For the bafled 56)-MHz prohler/RASS. the propased sites are acceptable at all of the locations and sume of the altemutive sites are aceeptable. The 915-MHz profiler/RASS is aceptable at all sites and alternatives. The 405-MHz profilet/RASS is also acteptable at all sites and alternatives.

The modified CNR predictions surtmarized in Table E.II indicate that the ARM proposed plan for locating profiler/RASSs is acceptable: (t) tor the central facility. an unbafled 50-MHz protter/RASS along with a 915-MHz profiler/RASS. and (2) for each of the boundary facilities. a tatfted 50 MEZz profiler/RASS and a $915 . \mathrm{MHz}$ protiler/RASS.

The Fidell method was used to give supplementary information on individual annoyance (given information about the state and attitudes of the individual under consideration using the dectision ittdex). By using the usual level of slightly annoyed as a measure of acceptability (a conservative measure). the Fidell method supports the predictions of the modifted CNR model in that all of the proposed sites were found to be acceptable. 


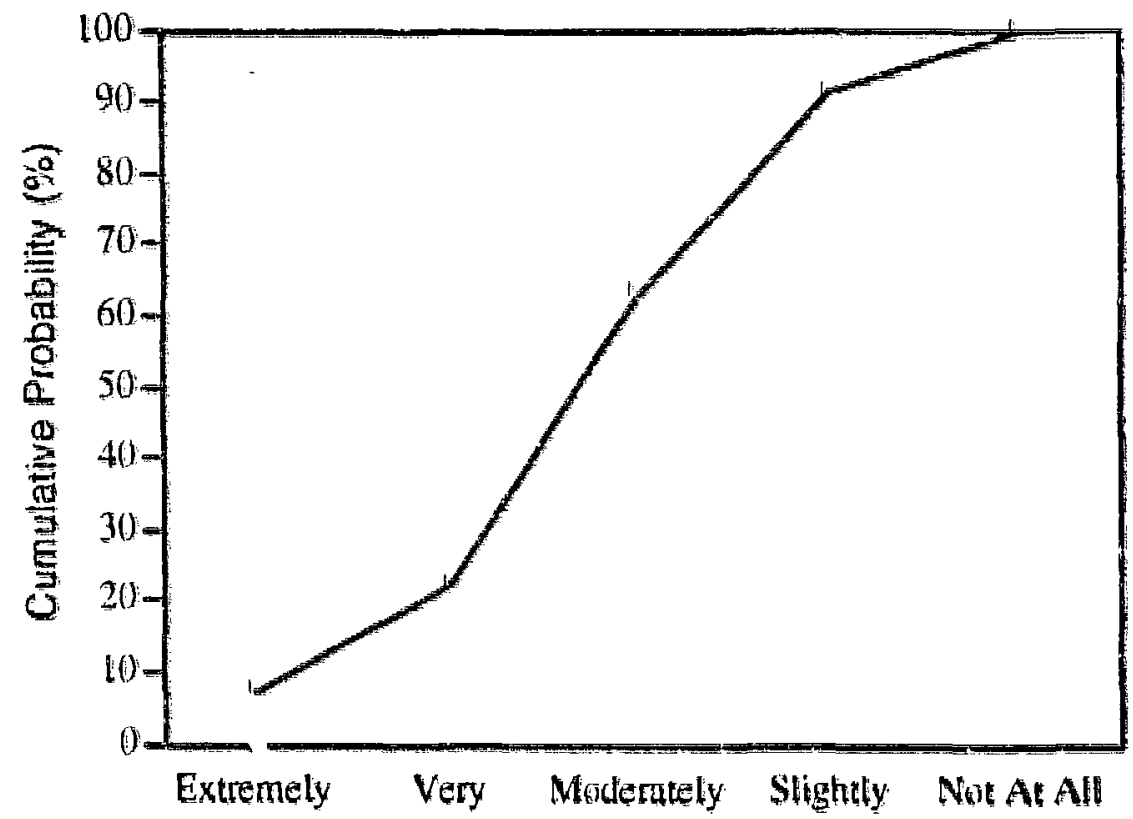

Figure E.5 Cumulative Probability vs. Fidell's Category of Annoyance 
Table E.3 Public Aeaction to Unbaffled 50-MHz Profilez/RASS (for Fidell method, tolerance index $=$ decision index $=0$ ).

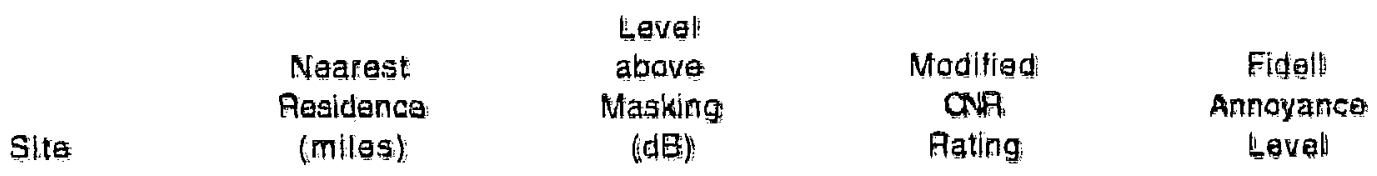

Grant County, Oklahoma, Contral Facility

\begin{tabular}{|c|c|c|c|c|}
\hline Fropoged: & 2.1 & 13 & 果 & Not Al All \\
\hline AlE. 1 & 1.9 & $1: 4$ & 日 & Not Alli \\
\hline Al: 2 & 2.0 & 14 & B & Not Al All \\
\hline
\end{tabular}

Okmulgee Counk, Oklahoma

\begin{tabular}{|c|c|c|c|c|}
\hline Propoged: & 0.7 & 27 & $E$ & Moderately \\
\hline Alt. 2 & 0.5 & 3) & F & Medoratoly \\
\hline Alt: 3 & 0.0 & 29 & 緊 & Modarataly \\
\hline
\end{tabular}

Meclain County, Oklahoma

$\begin{array}{lllll}\text { Proposed } & 0.6 & 29 & \text { E } & \text { Modaratoly } \\ \text { Alt. } 2 & 0.5 & 31 & F & \text { Modeately } \\ \text { Alt. } 3 & 0.6 & 29 & \text { E } & \text { Modanately }\end{array}$

Woodward County, oklahoma

$\begin{array}{ll}\text { Proposed } & 0.6 \\ \text { Alt. } 1 & 0.7 \\ \text { Alt. } 2 & 0.7\end{array}$

Montgomory County, Kansas
0.6

Alt. 1 0.5

Alf. 2

0.5

Marion County. Kansas

Proposod

A.t. 2

Alt. 3

0.6

0.6

0.5
29

27

27
E

E

$\varepsilon$
Modaratoly Moderately Moderaloly

Kiowa County. Kansas

$\begin{array}{lllll}\text { Froposed } & 0.7 & 27 & E & \text { Moderately } \\ \text { Alt. } & 0.8 & 26 & E & \text { Slightly } \\ \text { Ailt. } 2 & 0.5 & 31 & F & \text { Moderately } \\ \text { Alt. j } & 0.7 & 27 & E & \text { Moderately }\end{array}$


Table E.4 Public Feaction to 915-MHz Profiler/AASS (for Fidell method, tolerance index $\equiv$ decision index $=0$ ).

\begin{tabular}{|c|c|c|c|c|}
\hline Site & $\begin{array}{l}\text { Nearest } \\
\text { Pesidance } \\
\text { (miles) }\end{array}$ & $\begin{array}{c}\text { Leveli } \\
\text { above } \\
\text { Masking } \\
\text { idan }\end{array}$ & $\begin{array}{c}\text { Modifigd } \\
\text { off } \\
\text { Fating }\end{array}$ & $\begin{array}{c}\text { Fidelf } \\
\text { Annoyance } \\
\text { Level }\end{array}$ \\
\hline \multicolumn{5}{|c|}{ Qrant Couniv Jklahoma, Contral Facillty } \\
\hline Proposed & 2.1 & 0 & A & Not At All \\
\hline Al: 1 & 1,9 & 0 & A & Not At All \\
\hline Alt. 2 & 2,0 & a. & A & Not al All \\
\hline \multicolumn{5}{|c|}{ Okmulge日 County, Oklahorna } \\
\hline Propoged & $0 ; 7$ & 14.4 & $A$ & Nol Al all \\
\hline Alt. 2 & 0.5 & 23 & $A$ & Sligintiy \\
\hline Alt. 3 & 0.6 & 118 & A & sllghily \\
\hline \multicolumn{5}{|c|}{ MeClain County, Oklahoma } \\
\hline Proposad & 0.6 & 10 & A & Slight \\
\hline Alt. 2 & 0.5 & 23 & A & Slighnty \\
\hline All: 3 & 0.0 & 18 & A & Slighth \\
\hline \multicolumn{5}{|c|}{ Woedward Couñy, Oklahoma } \\
\hline Froposod & 0.6 & 19 & $A$ & slightily \\
\hline Alt. + & 0.7 & 14 & A & Nol At All \\
\hline Alt. 2 & 0.7 & 14. & A & Noll al All \\
\hline \multicolumn{5}{|c|}{ Menkgomary County, Kansas } \\
\hline Preposed: & 0.5 & 23 & $A$ & Slighty \\
\hline Alk. $\overline{2}$ & 0.5 & 23 & $A$ & Slightily \\
\hline Al: 3 & 0.5 & 23 & A & Slighty \\
\hline \multicolumn{5}{|c|}{ Marion Ceunty, Kansas } \\
\hline Proposad & 0.5 & 23 & A & Stightly \\
\hline Alt. 1 & 0.6 & $: 9$ & A & Slighuly \\
\hline Alt. 2 & 0.5 & $2 \sqrt{3}$ & A & Stigholy \\
\hline \multicolumn{5}{|c|}{ Kiowa Coumly. Kansas } \\
\hline Proposed & 0.7 & $n 4$ & $\mathbf{A}$ & Nol Al All \\
\hline Alt. $t$ & 0.0 & +1 & A & Nól Al All \\
\hline Al: 2 & 0.5 & 23 & A & Slightly \\
\hline Alt. 3 & 0.7 & 14 & $A$ & Not Al All \\
\hline
\end{tabular}


Table E.5 Public Reaction to Baffled 50-MHz Protiter/AASS (for Fidell method, toleance index $=$ decision index $=0$ )

\begin{tabular}{|c|c|c|c|c|}
\hline Site & $\begin{array}{c}\text { Nearest } \\
\text { Pesidence } \\
\text { (miles) }\end{array}$ & $\begin{array}{c}\text { Level } \\
\text { above } \\
\text { Masking: } \\
\text { (ddE) }\end{array}$ & $\begin{array}{c}\text { Modified } \\
\text { oNR } \\
\text { Aating }\end{array}$ & $\begin{array}{c}\text { Fidgall } \\
\text { Annoyance } \\
\text { Levall }\end{array}$ \\
\hline
\end{tabular}

Crant County, Oklahoma, Contral Facllty

$\begin{array}{lllll}\text { Proposed } & 2.1 & 3 & B & \text { Nol At All } \\ \text { Alk. } 1 & 1.9 & 4 & B & \text { Not At All } \\ \text { Alk. } 2 & 2.0 & 4 & B & \text { Not Al All }\end{array}$

Oknulgẹ County, Qkahoma

$\begin{array}{lllll}\text { Propoged } & 0.7 & 17 & 6 & \text { Slighnly } \\ \text { Alt. } 2 & 0.5 & 20 & 0 & \text { Slighthy } \\ \text { Alt. } 3 & 0.6 & 19 & \mathrm{C} & \text { Slightly }\end{array}$

MteClain County, Oklahoma

$\begin{array}{lllll}\text { Proposed } & 0.6 & 19 & 0 & \text { Slightly } \\ \text { Alt. } 2 & 0.5 & 21 & 0 & \text { Stightly } \\ \text { All. } 3 & 0.8 & 10 & 6 & \text { Slightly }\end{array}$

Woodward County, Oklahoma

$\begin{array}{lllll}\text { Fropasad: } & 0.6 & 15 & c & \text { Slightly } \\ \text { Alt. } & 0.7 & 17 & c & \text { Slightly } \\ \text { Alt. } 2 & 0.7 & 17 & c & \text { Slightivy }\end{array}$

Montgomery Counly, Kansas

Proposed:

All. 1 0.5

AlR. 2

0.5

Marlon Counly, Kansas

Proposed

All. 2

Alt. J

0.6

0.6

0.5

Kiowa Gounty, Kansas

\begin{tabular}{|c|c|c|c|c|}
\hline Proposed & 0.7 & 17 & C & Slightly \\
\hline Alk. 1 & 0.8 & 16 & 3 & Nol At Alt \\
\hline All 2 & 0.5 & 2 & $D$ & Stightly \\
\hline All. 3 & $0 . \overline{7}$ & 17 & $c$ & Slightly \\
\hline
\end{tabular}


Table E.6 Public feaction to $405-M H z$ Profiler/AASS (for Fidall method, toleance index = decision index $=0$ )

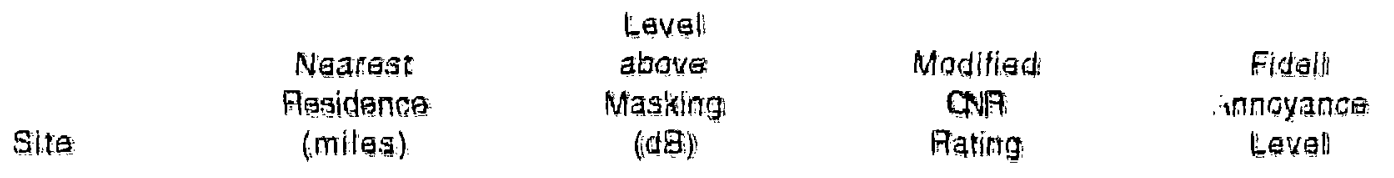

orant County, Okdahoma, Central Fagility

\begin{tabular}{|c|c|c|c|c|}
\hline Proposed & 2.1 & 0 & A & Not Ait All \\
\hline All. $t$ & 1,9 & (1): & $A$ & Not A: Al! \\
\hline Alt. 2 & 20 & 0 & A & MoK AV All \\
\hline
\end{tabular}

Qknulgoe County, Oktahoma:

$\begin{array}{lll}\text { Prepposed } & 0.7 & 24 \\ \text { Alt. } 2 & 0.5 & j 0 \\ \text { Alt. J } & 0.7 & 27\end{array}$

Meclain County, Oklahoma

Proposed

0.6

Alt, 2

0.5

Alt: 3

O.6.

27

30

27

Woodward Counts, Okahoma
Froposed

Alk. 1

Alt. 2
0.6

0.7

0.7
27

24

24 a

a.

c.
Stighthy

Modenably

silghily
Montgumery County, Kansas.

\section{Proposad}

Alt.

Alt. 2

Marion County, Kansas

Proposad

센, 2

A|t. 2

Kowa Count\%. Kansas

Frofrosed

Alt. +

Alt.

Alt, 3
0.6

0.5

0.5.
27

30

30
屯

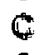

6
Sligtioly

Modention

Sligh

$\begin{array}{ll}6 & \text { Slighuly } \\ 3 & \text { Slightly } \\ 3 & \text { Stightly }\end{array}$


Table E.7 Public Reaction to Unbaffied 50-MHz Profiler/FASSS (for Fidell method, tolerance index $=$ decision index $=+2$ )

\begin{tabular}{|c|c|c|c|c|}
\hline Site & $\begin{array}{c}\text { Nearest } \\
\text { Aesidence } \\
\text { (miles) }\end{array}$ & $\begin{array}{c}\text { Leval } \\
\text { above } \\
\text { Masking } \\
\text { (d日) }\end{array}$ & $\begin{array}{c}\text { Modified } \\
\text { anR } \\
\text { Fating }\end{array}$ & $\begin{array}{c}\text { Fidell } \\
\text { Antoyance } \\
\text { Level }\end{array}$ \\
\hline
\end{tabular}

Grank County, Oklahoma, Central Facility

\begin{tabular}{|c|c|c|c|c|}
\hline Proposed: & 2.1 & 13 & $B$ & Not At All \\
\hline Alt, : & 1.9 & $1: 4$ & B: & Not At Aill \\
\hline Alt. 2 & 2.0 & 14 & B & Not At All \\
\hline
\end{tabular}

Okmulgea County, Oklahoma

Proposed

0.7

A|t. 2

0.5

A|t. 3
27

31

29
E

$F$

E
Slightly Moderately

Sighuly

Meclain County, Pklahome

Proposed

Alt. 2

Alt. 3
0.0

0.5

0.6
29

$3 \pi$

29
E

$F$

E
Silghtly

Modorately

Slightly

Woodward County, Oklahoma

Froposed

Q.6

Alk. 1

0.7

Alk. 2
29

27

27
E

E

E

E

F

$F$
Sllighty

Slightly

Sulightly

Monlgomery Coumly, Kansas

\section{Proposod}

Alt. 1

Alt. 2

Marion County. Kansas

Proposod

Alt. 2

Alt. 3

Kiowa Gounty, Kansas

Proposed:

Alt. 1

Alt. 2

A|t. 5
0.6

0.5

0.5

0.6

0.6

0.5
29

31

3.1
Silightly

Modarately

Moderatoly
29

29

31

E

Silghnity

Slightly

Modenarolyy

$\begin{array}{ll}\text { E } & \text { Slightly } \\ \text { F } & \text { Slighlly } \\ \text { E } & \text { Modatately }\end{array}$

27

26

औ1

27

E

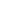


Table E.8 Public Reaction to 915-MHz Profiler/RASS (for Fidell method, tolerance index $=$ decision index $=+2$ )

\begin{tabular}{|c|c|c|c|c|}
\hline Site & $\begin{array}{c}\text { Nearest } \\
\text { Aesidence } \\
\text { (miles) }\end{array}$ & $\begin{array}{l}\text { Level } \\
\text { above } \\
\text { Maskung } \\
\text { (dB) }\end{array}$ & $\begin{array}{c}\text { Moditied } \\
\text { avR } \\
\text { Rating }\end{array}$ & $\begin{array}{c}\text { Fidell } \\
\text { Annoyance } \\
\text { Level }\end{array}$ \\
\hline
\end{tabular}

Grant County, Oklahoma, Central Facility

$\begin{array}{lllll}\text { Propoged } & 2 . \dagger & 0 & \text { A } & \text { Not At All } \\ \text { Alt. 10 } & 1.9 & 0 & \text { A } & \text { Not At All } \\ \text { Alt. } 2 & 2.0 & 0 & \text { A } & \text { Not At All }\end{array}$

Okmulgeg County, Oklahoma

$\begin{array}{lll}\text { Propoged } & 0.7 & 14 \\ \text { Alt. } 2 & 0.5 & 23 \\ \text { Alt. } 3 & 0.6 & 10\end{array}$

A

A

A
Nat At All

Slightly

Nol At All

MeClain Gounty, Oklahorna

$\begin{array}{lll}\text { Proposed } & 0.6 & 18 \\ \text { Alt. } 2 & 0.5 & 23 \\ \text { Alt. } 3 & 0.6 & 18\end{array}$

A

Not at All

A

Stightly

Alt. 3

18

Nol Al All

Woodward Gounty, Oklahoma

Proposed

0.6

Alt. 1

Alt. 2

0.7

0.7

Montgomery County, Kansas.

Propesed:

0.6

All. 1

0.5

Alt. 2

0.5

Manion County, Kansas

Proposed

Alt. 2

Alt. 3

Kiowa Coumty, Kansas
0.6

0.6

0.5
19

14

14
A

A

A
Nol Al AlD

Nol al all

Not At All
18

23

23
A

A

A

A

A
Nol at All

Stightily

Slightly
Hropeced

Alt. 1

A). 2

Alt. 3
0.7

0.8

0.5

0.7
ก⿻

18

23
A

.

Nol Al AIt

Not A! siil

Stignintly 
Table E.9 Public Aeaction to Baffled 50-MHz Protiler/AASS (for Fidell method, tolerance index $=$ decision index $=+2$ )

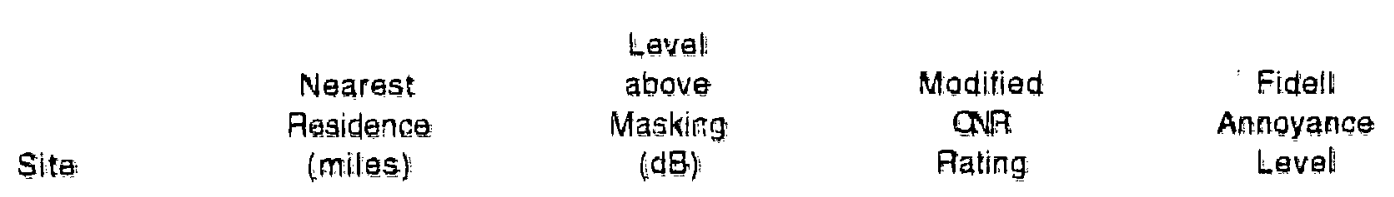

Grant Couny, Oklahoma, Central Facility

$\begin{array}{lllll}\text { Propoged } & 2.1 & 3 & 8 & \text { Not At All } \\ \text { Alt. } 1 & 1.9 & 4 & B & \text { Not At All } \\ \text { Alt. } 2 & 2.0 & 4 & B & \text { No: At All }\end{array}$

Qkmulgee County, Oklahamat

$\begin{array}{lllll}\text { Proposed } & 0.7 & 17 & C & \text { Nol At All } \\ \text { Alt. } 2 & 25 & 21 & 0 & \text { Sllghuly } \\ \text { Alt. } 3 & 0.6 & 19 & \text { C } & \text { Nol Al All }\end{array}$

McGlain County, Oklahuma

$\begin{array}{lllll}\text { Proposed } & 0.6 & 19 & \text { C } & \text { Not Al All } \\ \text { Alt. } 2 & 0.5 & 2 t & 0 & \text { Stighily } \\ \text { Alt. } 3 & 0.6 & 19 & \text { C } & \text { Not At All }\end{array}$

Woodward County, Oklahoma

$\begin{array}{lll}\text { Preposed } & 0.6 & 19\end{array}$

A.t. $1 \quad 0.7$

Alt. 2

0.7

Monkgomery County. Kansas

Proposed

Alk. 1

Alk. 2

Mation County, Kansas
Proposed

Alt. 2

Alk, 3

Kiowa County, Kansas

Proposod

Alt. $\hbar$

Alt. 2

Alt. 3
0.6

0.5

0.5

0.6

0.6

0.5

0.7

0.8

0.5

0.7
19

17 $c$

c

5.
Not At All

No at all

Nơ at all
19

21

21 $c$

(D)

D
Nol at All

Slighuly

Slightly

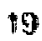

19

21
C

C

D
Nat Al All

Not at All

Stightly
Nol At All

17
16

C

$\overline{\mathrm{g}}$

0

c
Not Al All

Slighlly

Not At All 
Table E. 10 Public Reaction to 405-MHz Profiler/RASS (for Fidell method, tolerance index = decișion index $=+2$ )

\begin{tabular}{|c|c|c|c|c|}
\hline Sita & $\begin{array}{c}\text { Nearest } \\
\text { Aesidence } \\
\text { (miles) }\end{array}$ & $\begin{array}{c}\text { Level } \\
\text { above } \\
\text { Masking: } \\
\text { (dB) }\end{array}$ & $\begin{array}{c}\text { Modified } \\
\text { ONA } \\
\text { Pating }\end{array}$ & $\begin{array}{c}\text { Fidell } \\
\text { Annoyance } \\
\text { Level }\end{array}$ \\
\hline
\end{tabular}

Grant County, Oklahoma, Central Facility.

$\begin{array}{lllll}\text { Proposed } & 2,1 & 0 & \text { A } & \text { Not At All } \\ \text { Alt. } 1 & 1.9 & 0 & \text { A } & \text { Not Al All } \\ \text { All. } 2 & 2.0 & 0 & \text { A } & \text { Not At All }\end{array}$

Okmulgeg: County, Oklahoma

$\begin{array}{lll}\text { Froposed } & 0.7 & 24 \\ \text { Alt. } 2 & 0.5 & 30 \\ \text { Alt. } 3 & 0.0 & 27\end{array}$

MeClain County, Olstahoma

$\begin{array}{lll}\text { Proposed } & 0.6 & 27 \\ \text { Alt. } 2 & 0.5 & 30 \\ \text { Alt. } 3 & 0.6 & 27\end{array}$

A|t. 3

0.6

27

$\begin{array}{ll}\text { C } & \text { Slighuly } \\ \text { C } & \text { Moutanataly } \\ \text { Stlighty }\end{array}$

Woodward County, Oklahoma
Proposed
0.0
27
$c$
Sllghtly
Alt. 1
0.7
24
Alk. 2
0.7
24
要
Sllightly
stighaly

Montgomery County. Kansas

$\begin{array}{lll}\text { Proposod } & 0.6 & 27 \\ \text { Alt. } 1 & 0.5 & 30 \\ \text { Alt. } 2 & 0.5 & 30\end{array}$

Alk. 2

0.5

Marion County, Kansas

Froposod

Alt. 2

Alt, 3

Kiowa Geunty. Kansas

Proposed

Alt. 1

Alt. 2

0.6

0.6

0.5

Alt: 3
0.7

0.8

0.5

0.7
27

27

30
30

30
C

c
Silightly

Modotaloly

Modoratoly 
Table E.11 Public Reaction to Unbaftled 50-NHtz Profiler/fASS for Fidell melhod, toletance index $=$ decision index $=+10$ )

\begin{tabular}{|c|c|c|c|c|}
\hline & & Løvel: & & \\
\hline Slte: & $\begin{array}{c}\text { Nearest } \\
\text { Residence } \\
\text { (miles) }\end{array}$ & $\begin{array}{c}\text { abovo } \\
\text { Masking; } \\
\text { (dB) }\end{array}$ & $\begin{array}{l}\text { Modified } \\
\text { ONA } \\
\text { Pating }\end{array}$ & $\begin{array}{l}\text { Fidel } \\
\text { Annoyanee } \\
\text { Levell }\end{array}$ \\
\hline
\end{tabular}

Grant County, Oklahoma, Central Facility

\begin{tabular}{|c|c|c|c|c|}
\hline Proprised: & 2.1 & 13 & $B$ & Not A! All \\
\hline Al:. : & 1.9 & 14 & $\theta$ & Not at ali \\
\hline Alt. 2 & 2.0 & 1.4 & 9 & Not al All \\
\hline
\end{tabular}

Okmulge County, Okiahama

$\begin{array}{lll}\text { Propoged } & 0.7 & 27 \\ \text { A.t. } 2 & 0.5 & 31 \\ \text { Alk. } 3 & 0.6 & 29\end{array}$

$\begin{array}{ll}\text { E } & \text { Slightly } \\ \text { F } & \text { Silghtly } \\ \text { E } & \text { Stightimly }\end{array}$

MeClain County, OkJahoma

$\begin{array}{lllll}\text { Proposed } & 0.6 & 29 & \text { E } & \text { Slightlly } \\ \text { Alt. } 2 & 0.5 & 31 & F & \text { Slightly } \\ \text { Alt. } 3 & 0.6 & 29 & E & \text { Stlightly }\end{array}$

Woodward County. Qkahoma

Propoged $\quad 0.6$

Alt. $t \quad 0.7$

Alt. 2

0.7

Montgomgry County, Kansas

\section{Proposed}

Alt. $t$

Alt. 2

Marion County. Kansas.

\section{Proposod}

Alt. 2

Alt. $\mathrm{J}$

Klowa Gounty, Kansas

Proposed

Alt. $t$

Alt. 2

Ait. 3
0.6

0.5

0.5
29

27

\section{E}

E
Sligholy

Slightily

Slightlly
29

31

31
E

F

$F$
Sightlly

Slightly

Sllghtly
23

29

31
$E$

E

F
Stightly

Stighilly

Slightly

0.5

0.7

0.8

0.5

0.7
27

26

31

27
$E$

$E$

F

E
Slightly

Not Al All

Slightly

Slightly 
Table E.12 Public Reaction to 915-MHz Protiler/RASS for Fidell method tolerance index = decision index $=+10$ )

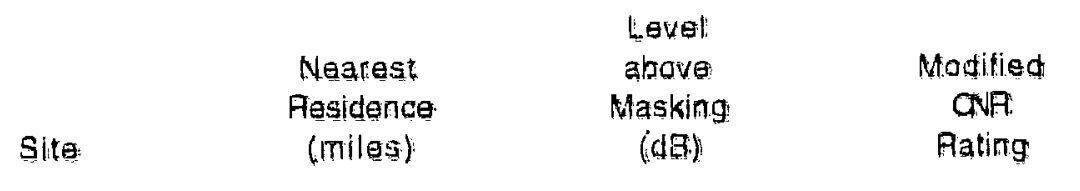

Fide!!

Annoyanco

Level

Grant Gounty, Oklahoma, Central Facility

$\begin{array}{lllll}\text { Proposed } & 2.1 & 0 & \text { A } & \text { Not At All } \\ \text { Alt. } 1 & 1.9 & 0 & \text { A } & \text { Not At All } \\ \text { Alt. } 2 & 2.0 & 0 & \text { A } & \text { Not At All }\end{array}$

Qkmulgae Counts, Oklanoma

\begin{tabular}{|c|c|c|c|c|}
\hline Proposad & 0.7 & 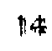 & A. & Nat At Al \\
\hline A $\mathrm{L}_{\mathrm{u},}^{*}, 2$ & 0.5 & 23 & $A$ & Not AI A \\
\hline All. 3 & 0.6 & 10 & A & Nol All Al \\
\hline
\end{tabular}

MoGlain County. Oklahoma

Proposad: 0.6

Alt. 2 A 0.5

Alt. ₹

Q: 6

Woodwarct Gounty, Oxlahoma

Proposod

Alt. 1

0.6

Alt. 2

0.7

0.7

Montgomery County, Kansas
Proposed

Alt. 1

Alt. 2

0.6

0.5

0.5

Marion Counly, Karsas

Froposed

0.6

Alt. 2

0.6

Alt. 3
23

18
A

A

A
Not Al All

Not at All

Not AI AII
18

14

14

\section{A \\ A}

A
Not at All

Nat A: All

Not At All
Kiowa County, Kansas

$\begin{array}{ll}\text { Froposed } & 0.7 \\ \text { Alt. } 1 & 0.8 \\ \text { Alt. } 2 & 0.5 \\ \text { Alt. } 3 & 0.7\end{array}$

0.7

0.8

0.5

0.7
18

23

23

18

18

25
A

A

A
Nol AI All

Nol Al All

Nor al All
Not Al All
A
Not Al All
A
Nol al All

A

A

A 
Table E.13 Publio Reaction to Bafflad 50-MHz Profiler/RASS (for Fidell method, tolerance index $=$ decision index $=+10$ )

\begin{tabular}{|c|c|c|c|c|}
\hline & $\begin{array}{l}\text { Nearest } \\
\text { Hesidance }\end{array}$ & $\begin{array}{c}\text { Level: } \\
\text { above } \\
\text { Masking }\end{array}$ & $\begin{array}{c}\text { Modilited } \\
\text { ONR }\end{array}$ & $\begin{array}{c}\text { Fidell } \\
\text { Annoyance }\end{array}$ \\
\hline Site: & (miles)" & (dB) & Hating: & Leval \\
\hline
\end{tabular}

Gank County, Okahoma, Central Facility

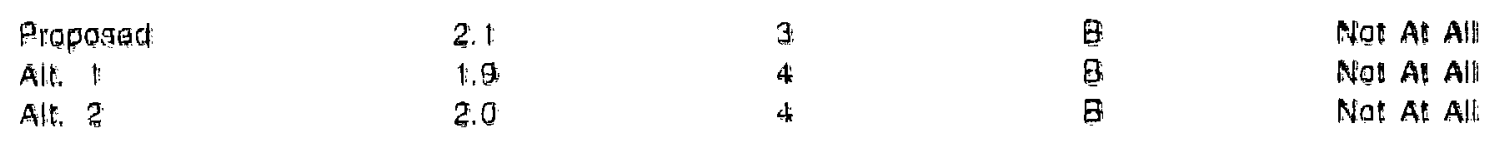

Okmulge日 Couniy, Qklahema

\begin{tabular}{|c|c|c|c|c|}
\hline Propozed & 0.7 & 17 & C & Nol AI All \\
\hline $\mathrm{A} \mid \mathrm{k}, 2$ & 0.5 & 211 & D & Not at all \\
\hline Alt: 0 & $0 ; \theta$ & 19 & c & Not Al All \\
\hline
\end{tabular}

Meclain: County, Qklahoma

$\begin{array}{lllll}\text { Proposed } & 0.6 & 19 & 0 & \text { Nat Al All } \\ \text { Alt. } 2 & 0.5 & 2 \dagger & 0 & \text { Nat Al All } \\ \text { Alt. } 3 & 0.6 & 19 & C & \text { Nol Al All }\end{array}$

Woodward Courity, Oklathoma

$\begin{array}{lllll}\text { Froposed } & 0.6 & 19 & \text { C } & \text { Nol Al All } \\ \text { Alt. } & 0.7 & n 7 & \text { C } & \text { Not At All } \\ \text { All. } 2 & 0.7 & 17 & \text { C } & \text { Nol Al All }\end{array}$

Montgomery County. Kansas.

Preposed

0.6

Alt. 1

0.5

All. 2

0.5

Marion County, Kansas

Proposed

0.6

Alt. 2

0.6

0.5

Alt. 3

Kiawa County. Kanses

Proposed

Ait. 1

0.7

0.8

0.5

Alt.

0.7

Alt. 3
19

$2 \pi$

$2 \pi$

19

19

21 c

$\mathrm{C}$

0
Nol All All

Not At All

Not At All $n \pi$

16

21

17
C

B

D

C
Not at All

Nōl Al all

Na: al all 
Table E.14 Public Reaction to 405-MHz Profiler/AASS (for Fidelt method, tolerance index = decision index $=+10$ )

\begin{tabular}{|c|c|c|c|c|}
\hline Silte & $\begin{array}{c}\text { Nearest } \\
\text { Aesidence } \\
\text { (miles) }\end{array}$ & $\begin{array}{l}\text { Level } \\
\text { above } \\
\text { Afasking } \\
\text { (dヨ) }\end{array}$ & $\begin{array}{l}\text { Modifiad } \\
\text { Cann } \\
\text { Rating }\end{array}$ & $\begin{array}{c}\text { Fidell } \\
\text { Annoyance } \\
\text { Level }\end{array}$ \\
\hline
\end{tabular}

Grant Coundy, Oklahoma, Central Facility

$\begin{array}{lllll}\text { Proposed } & 2.1 & 0 & \text { A } & \text { Not At All } \\ \text { Alt. } 1 & 1.9 & 0 & \text { A } & \text { Nat At All } \\ \text { Alt. } 2 & 2.0 & 0 & \text { A } & \text { Nat At All }\end{array}$

Otomulgoe County, Okanoma

\begin{tabular}{|c|c|c|c|c|}
\hline Propoged & 0.7 & 24 & $\theta$ & Nok A All \\
\hline Alt. 2 & 0.5 & 30 & C & Stganthy \\
\hline Alt: 3 & 0.3 & 27 & C & Not AI All \\
\hline
\end{tabular}

McClain County. Oklahorna

Propoged $\quad 0.6 \quad 27$

Alt. $2 \quad 0.5 \quad 30$

Alk. 3

30

0.6
Woodward County, Oklahorna
Progesad

0.6

Alt. 1

0.7

Alt. 2
27

24

24 c

c

$c$
Not Al All

Slighthly

Not Al All
Montgomery County, Kansas
Proposed:

Alt. I

Alt. 2

Marien County, Kansas

Proposed:

Alt. 2

Alt. 5

0.6

0.6

0.5
0.6

0.5

0.5
27

30

30
C

$B$

(3)
NOL A Al:

Not AB All

Nou al Alli
Liowa Gounty. Kansas
Proposed:

Alt. 1

Alt. 2

Alk. 3
0.7

0.8

0.5

0.7
27

$2 \pi$

30 c

C

C
Nol Al Al!

Slighily

Slightinty
Nol al All Not Al All

C

C Slightly 
Table E.15 Acceptable (A) and Unacceptable (U) Sites for the Profiler/RASSs using the Criteria of the Modified CNR Method for Acceptability of Noise impacts

Facility (County, State) $\quad$ Pigposed

Unbartled 50-MHz ProfileriRASS

Central (Grant Go. Qkata.)

Eoundary (MoClein Co. Okla.)

Boundary (Qkmulgee Ca, Okla.)

Eoundary (Woodward Co, Qkla.)

Goundary (Kiowe: Co, Kans.)

Boundary (Marion Co., Kans.)

Eoundary (Nontgomery Co., Kans.)

$\begin{array}{lll}A & A & \\ U & - & \\ U & - & \\ U & U & \\ U & \vdots & \\ U & - & \\ U & U & \end{array}$

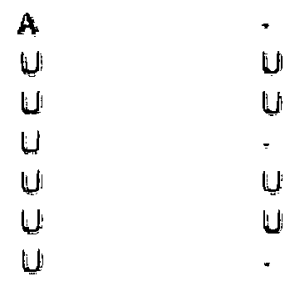

\section{Baffled S0inthz Peofilerifass}

Centrali (Grant Co, Okla.)

Boundary (McClain Co., Okla.)

Boundary (Okmulgea CQ. Qkla.)

Boundary (Woodward: Co, Okla.

Boundary (Kiowa Co., Kans.)

Boundary (Marion Co., Kang.)

Beundary (Montgomery Co., Kans.)

$\begin{array}{ll}A & \text { A } \\ \text { A } & \text { : } \\ \text { A } & \text { A } \\ \text { A } & \text { A } \\ \text { A } & : \\ \text { A } & \text { U }\end{array}$

\section{MHz Promlerfass}

Contral (Grant Co., Qkla.)

Boundary (McClain Co., Okla.)

Boundary (Okmulgea Co. Okla.)

Boundary (Woodwart Co., Okla.)

Boundary (niówa Co. Kans.)

Goundary (Marion Co., Kans.)

Boundary (Montgomary Co., Kans.:

A

A

A

A

A

A

A
A

-

-

A

A

*

A
A

A

A

A

A

A

A
A

A

$=$

A

U

\section{OS MHE RASS Frofilem/RASS}

Contral (Grant Co., Okla)

Boundary (McClain Co., Okta.)

Geundary (Okmulges Co. Okla.)

Bioundary (Woodward Co. Okla.)

Boundary (Kiowa Co., Kans.)

Boundary (Marion Co. Kans.)

Boundary (Montgomery Co., Kans.)

$\begin{array}{ll}\text { A } & \text { A } \\ \text { A } & \text {. } \\ \text { A } & \text { - } \\ \text { A } & \text { A } \\ \text { A } & \text { A } \\ \text { A } & \text { - } \\ \text { A } & \text { A }\end{array}$

A

A

A

A

$A$

A

A
A

A

A

A

- 


\section{Appondix $F$}

Fodoral Candidato Species Potentially Occutring in Counties Containing ARM project Contiral and Boundary Facilties 
$F+2$ 
Federal Candidate Species

\begin{tabular}{|c|c|c|}
\hline Stato & Spacies: & $\begin{array}{l}\text { Candidate } \\
\text { Category }\end{array}$ \\
\hline \multirow[t]{29}{*}{ KAKISAS } & Arkansas Fiver shiner & 1 \\
\hline & 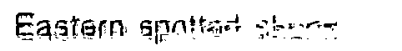 & $\therefore$ \\
\hline & Ferpuginious hawk & 2 \\
\hline & Snowy plover & 2 \\
\hline & -oggenhead shrike & 2 \\
\hline & Longubilted curlaw & 2. \\
\hline & Whirengased itso & 2 \\
\hline & Glack tunn & 2 \\
\hline & Blagtr natl & 2 \\
\hline & Henglow's gatrow & 8 \\
\hline & Baird's spanow & 2 \\
\hline & Alligator smapping turte & 2 \\
\hline & Texas hamed lizard & 2 \\
\hline & Give suckar & 2 \\
\hline & Ankartage dare & t \\
\hline & Sturgean chulb & 2 \\
\hline & Sickletin chub & 2 \\
\hline & Spocklod chut & 2 \\
\hline & Topaka shingr & 2 \\
\hline & Paddlotish & $\mathrm{z}$ \\
\hline & Westem tanstigll & 2 \\
\hline & Noosho, muka & 2 \\
\hline & Oumahila kidney-sthall & $\pi$ \\
\hline & 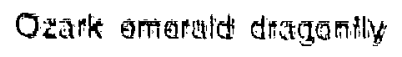 & 2 \\
\hline & Rogal mitllary butkertly & 2 \\
\hline & Clamton's Cave amphipod & 2 \\
\hline & Eateal kaxglove & $\bar{z}$ \\
\hline & Fumetlower & 2 \\
\hline & Weak nellta & 2 \\
\hline
\end{tabular}




\begin{tabular}{|c|c|}
\hline State: & Species \\
\hline
\end{tabular}

KANSAS (cont)

$\begin{array}{ll}\text { Qzark dropsead } & 2 \\ \text { Dwart burhead } & 2 \\ \text { Hall's bulrush } & 2 \\ \text { Hairy false mallow } & 2 \\ \text { Skinner's purple talse foxglova } & 2 \\ \text { Cleftsedge } & 2\end{array}$

OKLAHOKA

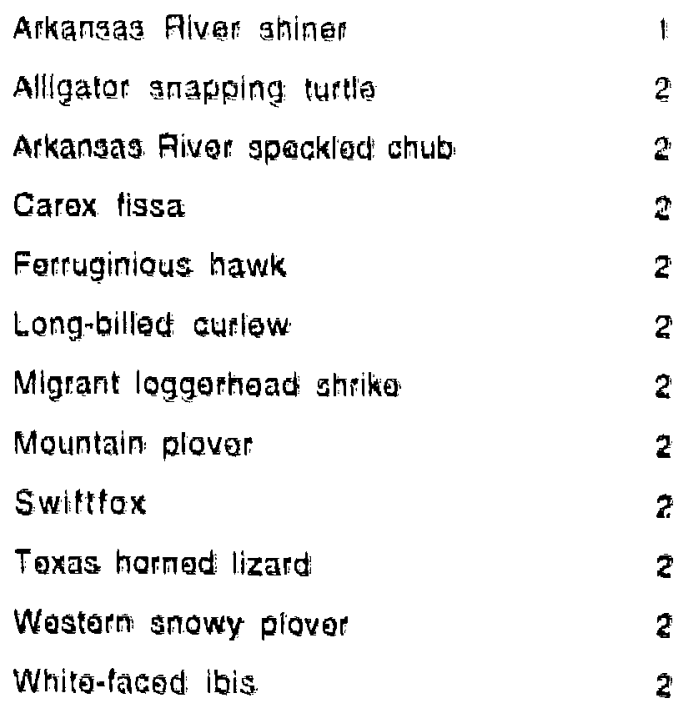

* Candidate $t$ species have the potontial tor an ollicial tedarall listing by the U.S. Fish and Wildlife Service. Candidate 2 spocios aro those por which the Fish and Wildite Service is collocting data on in andot to make a decision concorning thoit statu.

Source: U.S. Fish and Widlifa Sarvica. 
Appendix $\mathbf{G}$

Existing Land Use Maps of Vicinity around Boundary Facillties 
G.2 


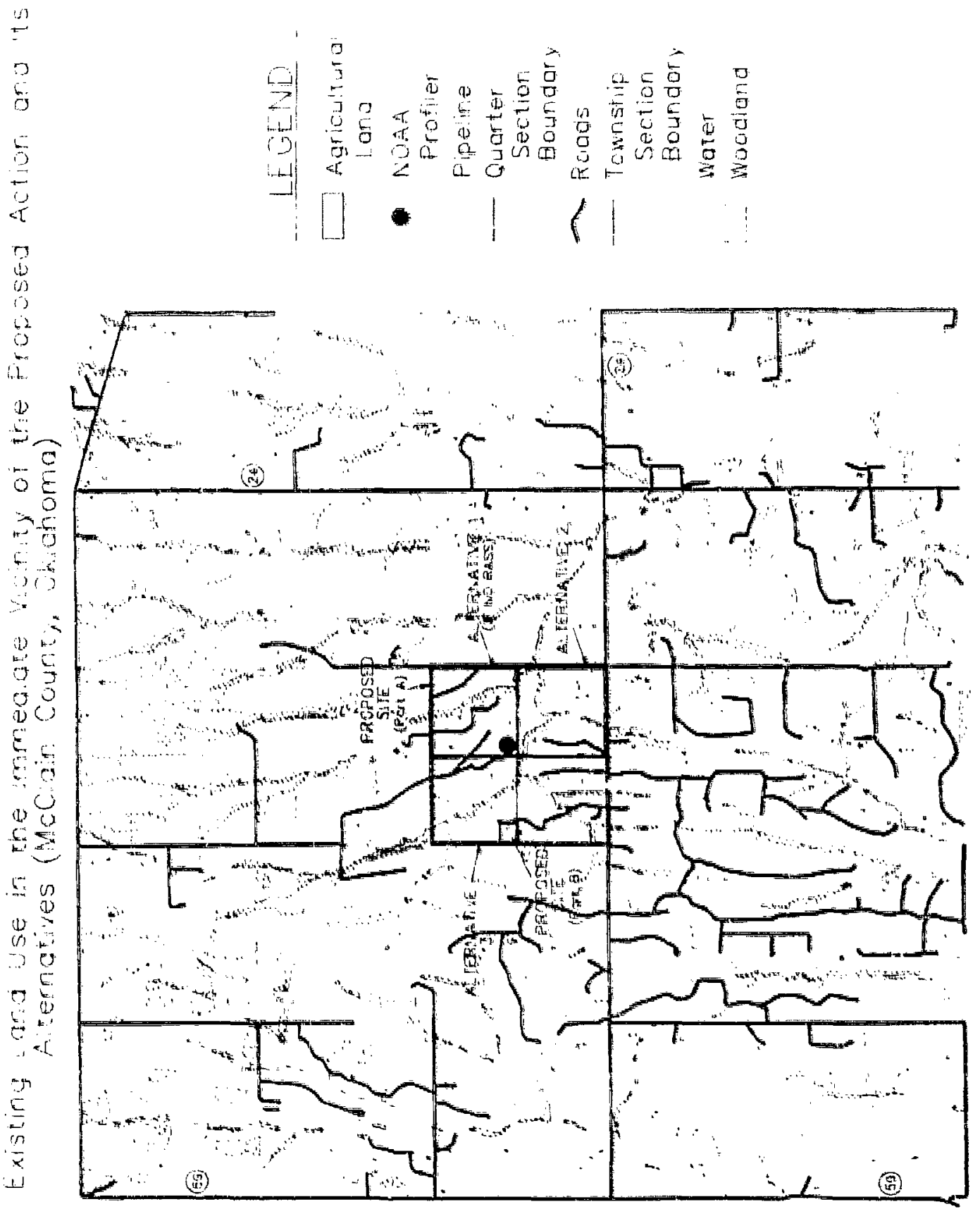




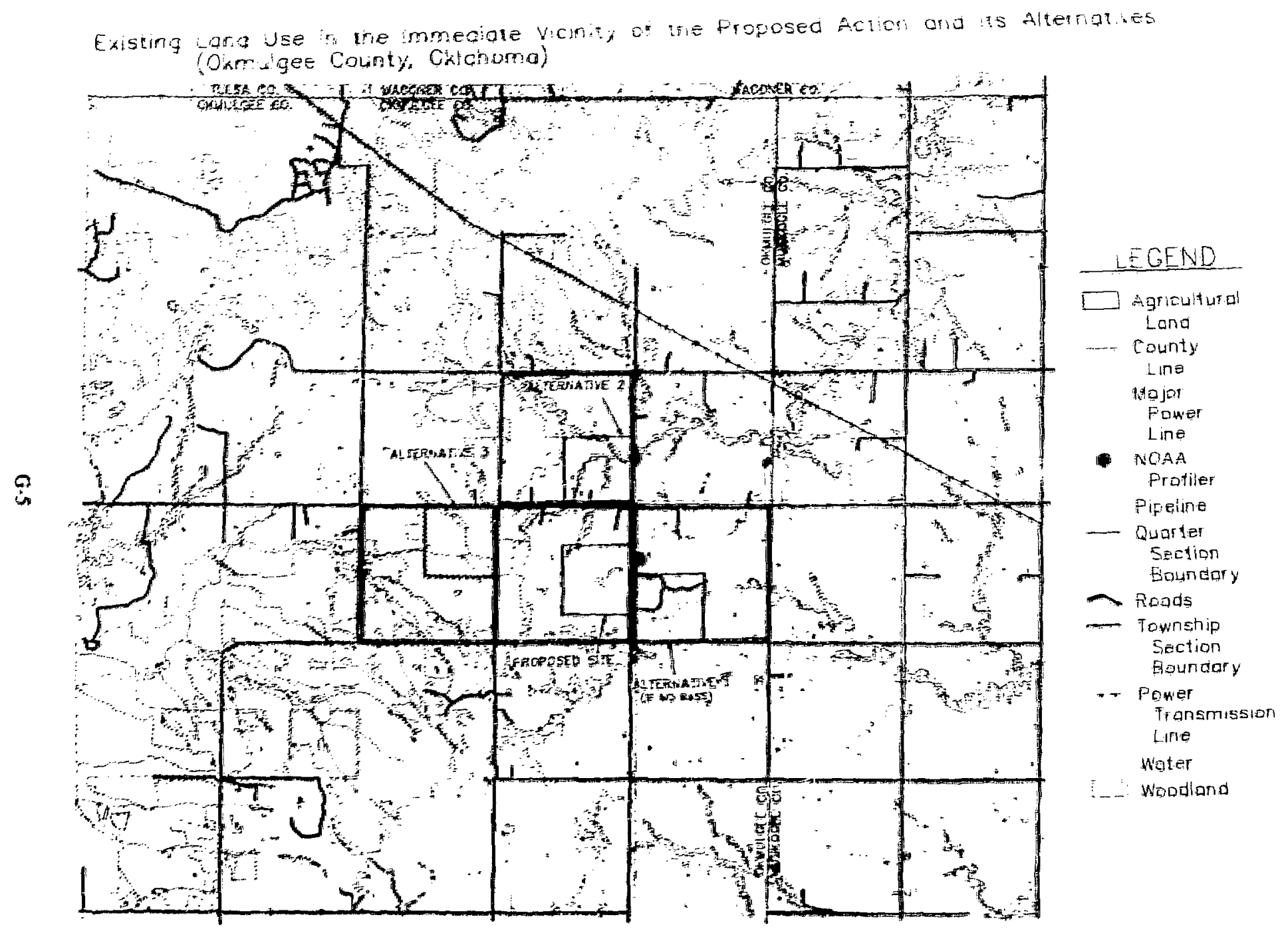




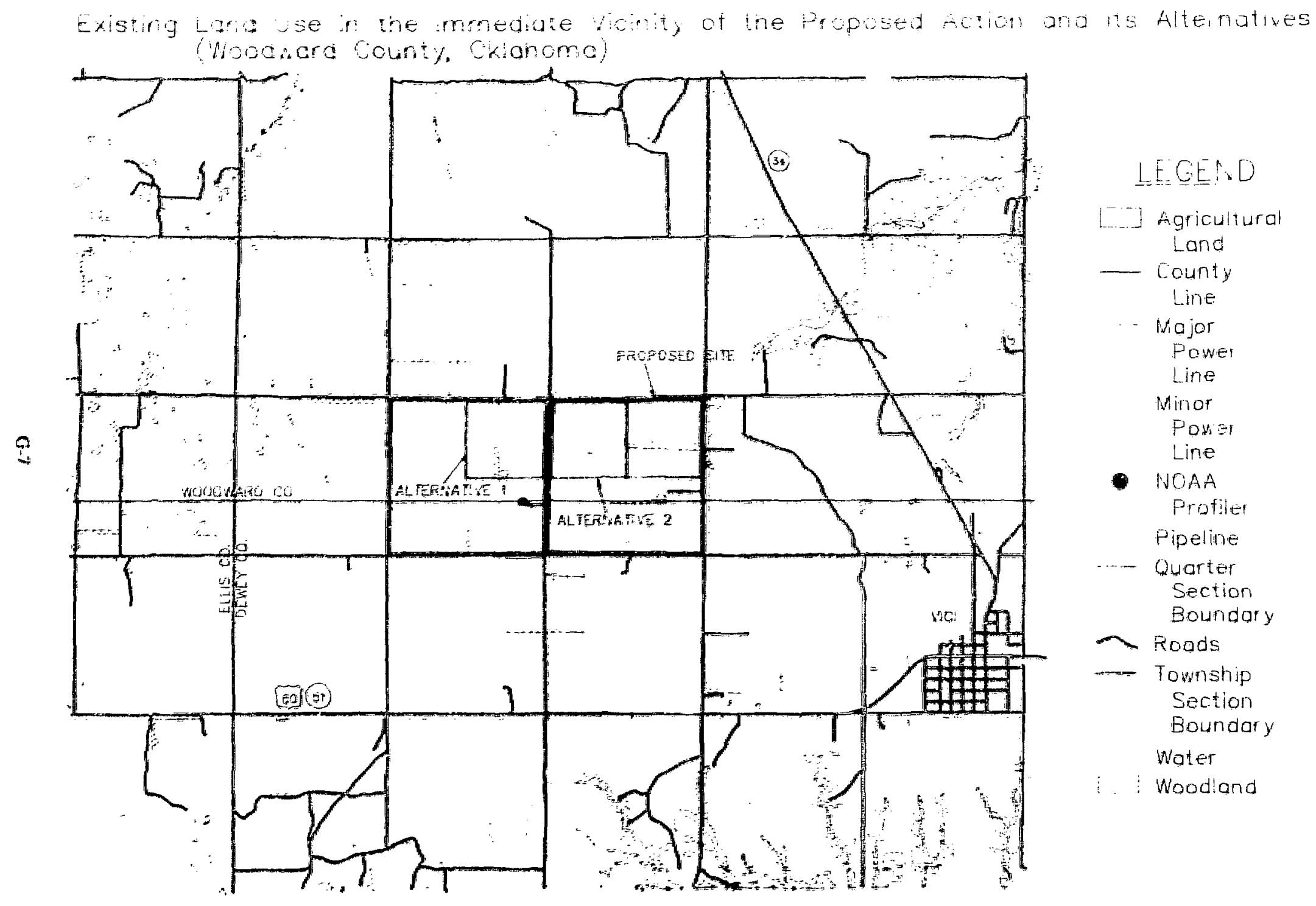




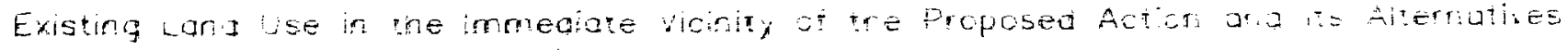

(ricia Conty ransas)

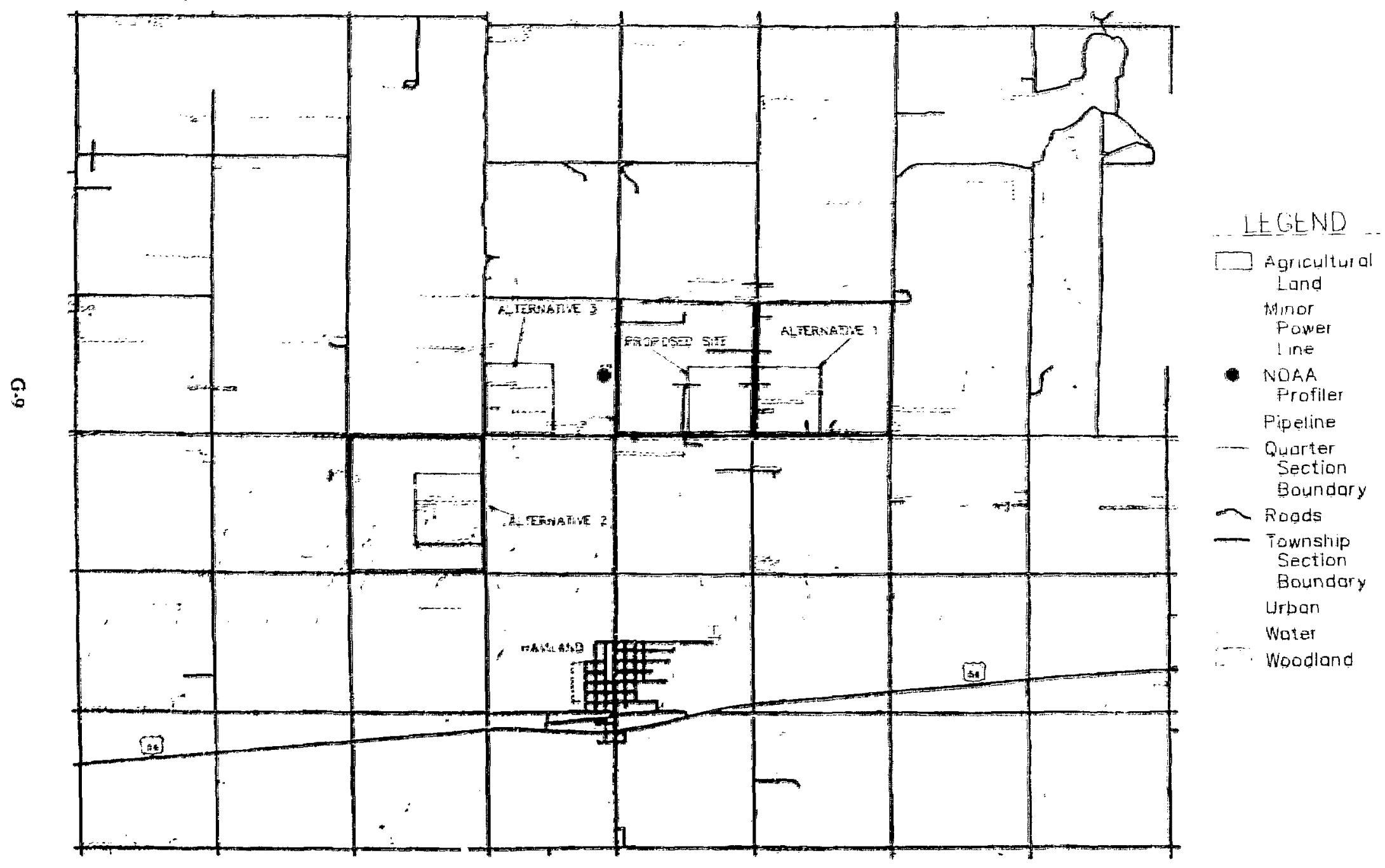


Existing Land Use in the Immediate Vicinity of the proposed Action and its Alternatives (Marion County, Kansas)

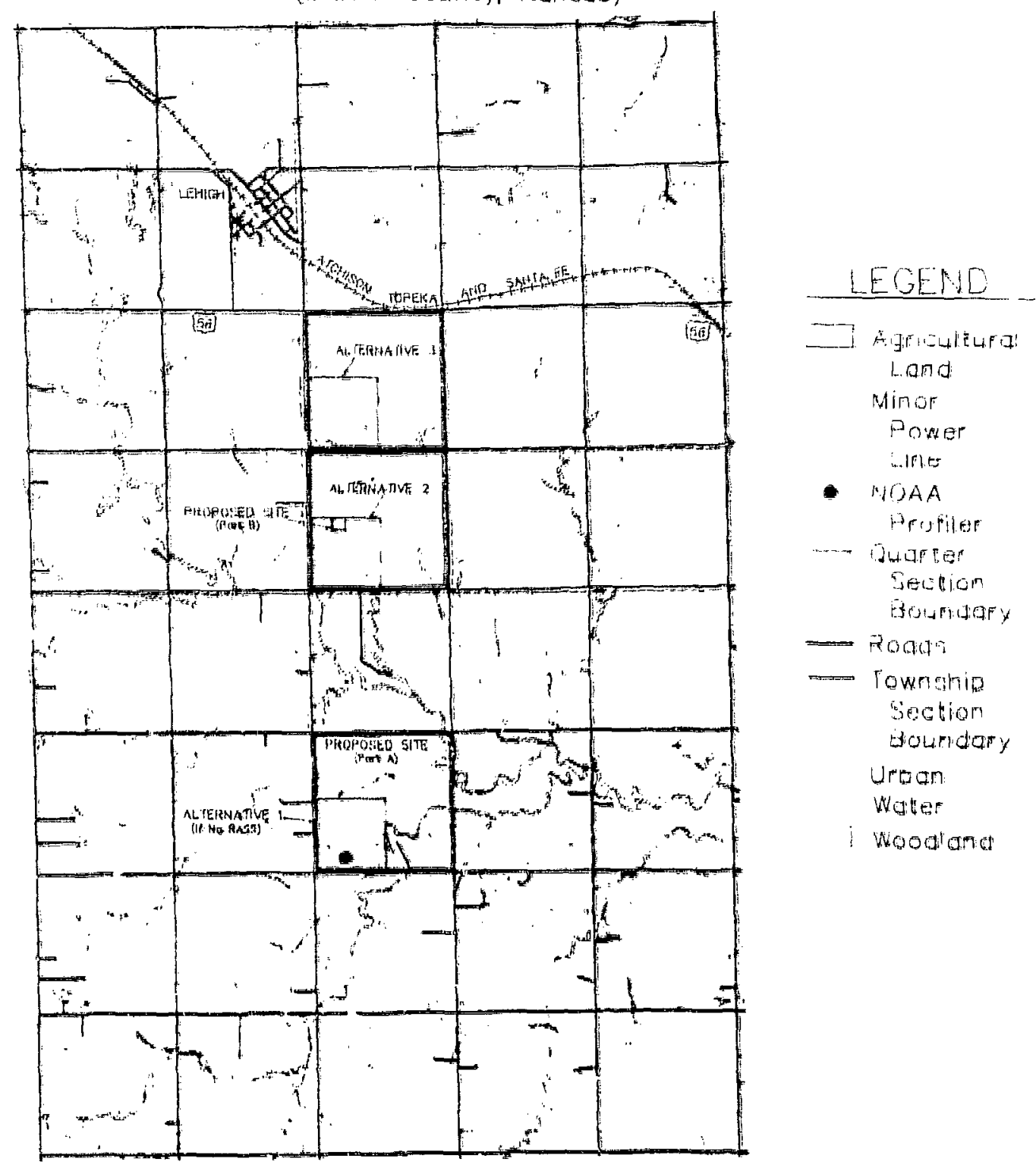

$(i-i)$ 


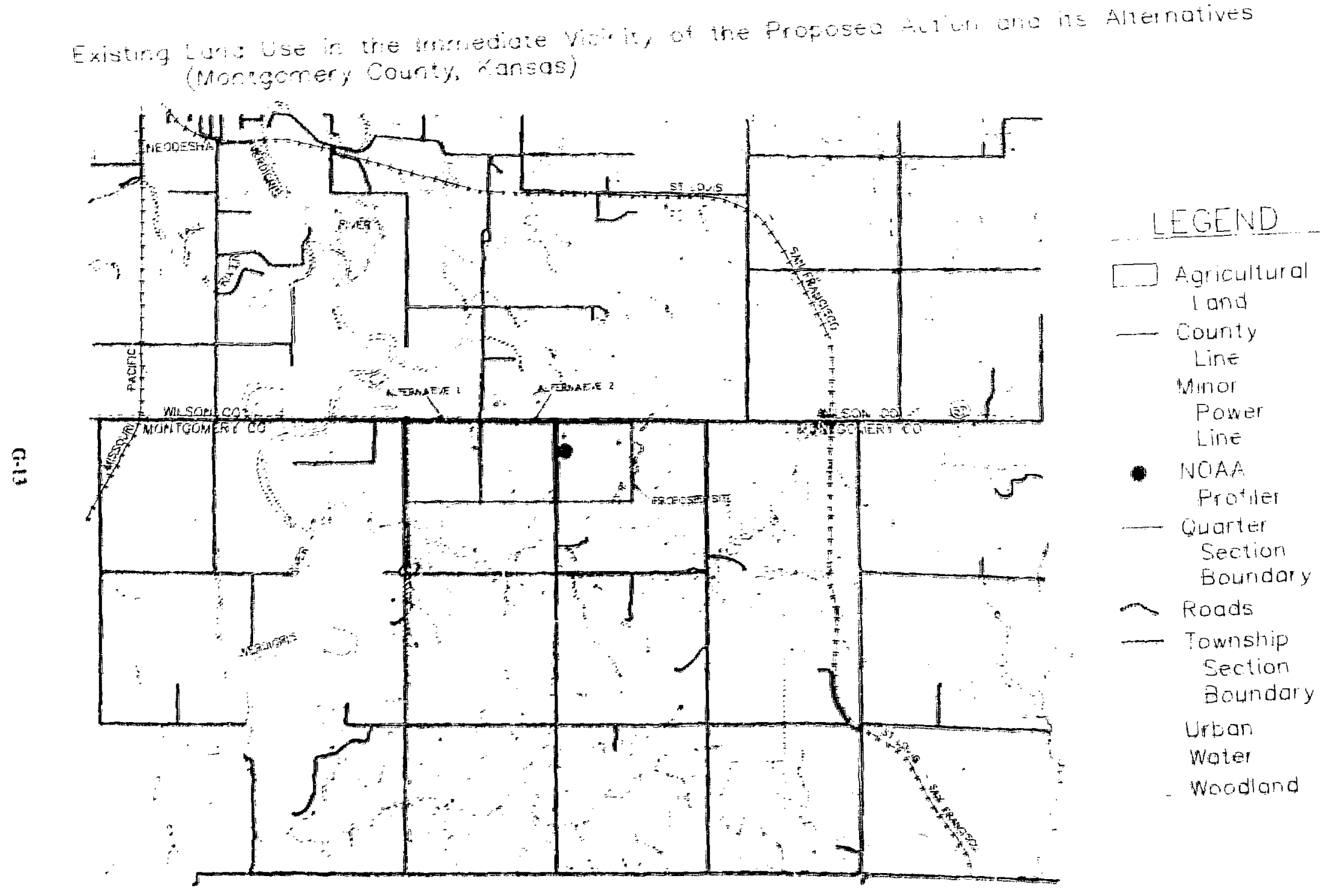


Appendix $H$

Photographs of Areas in Proximity to Grant and Mcclain County Facllitios 
H.2 


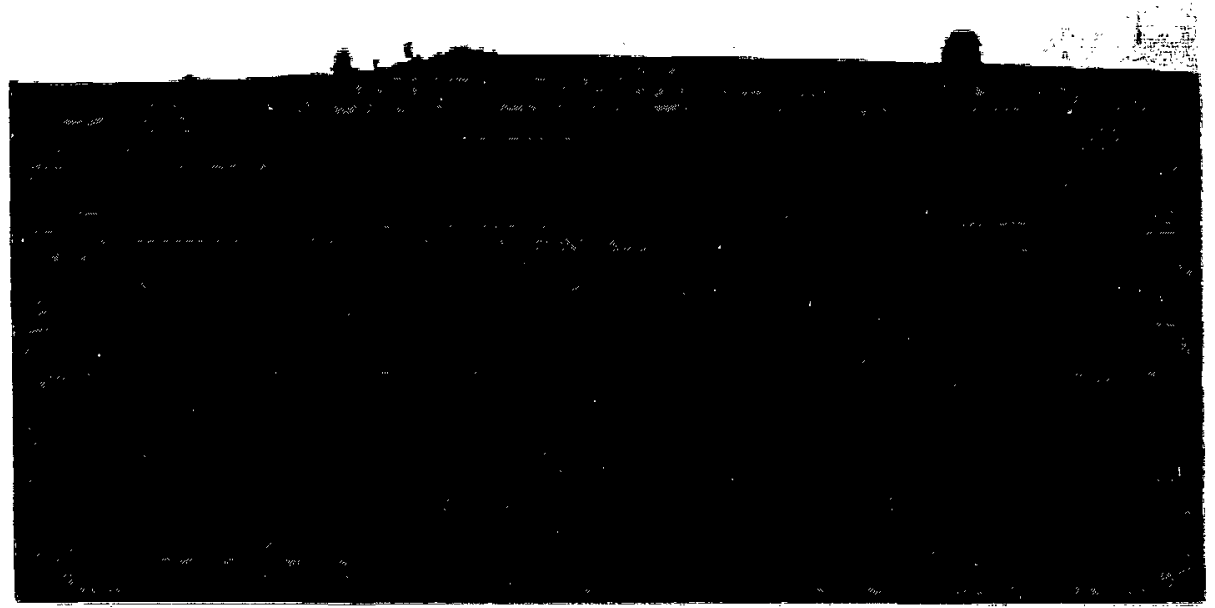

Foreground $(0-1 / 4 \mathrm{mi})$ View ol Proposed Silte tor Central Facility, Grant County, Oklahoma View Looking Southwest

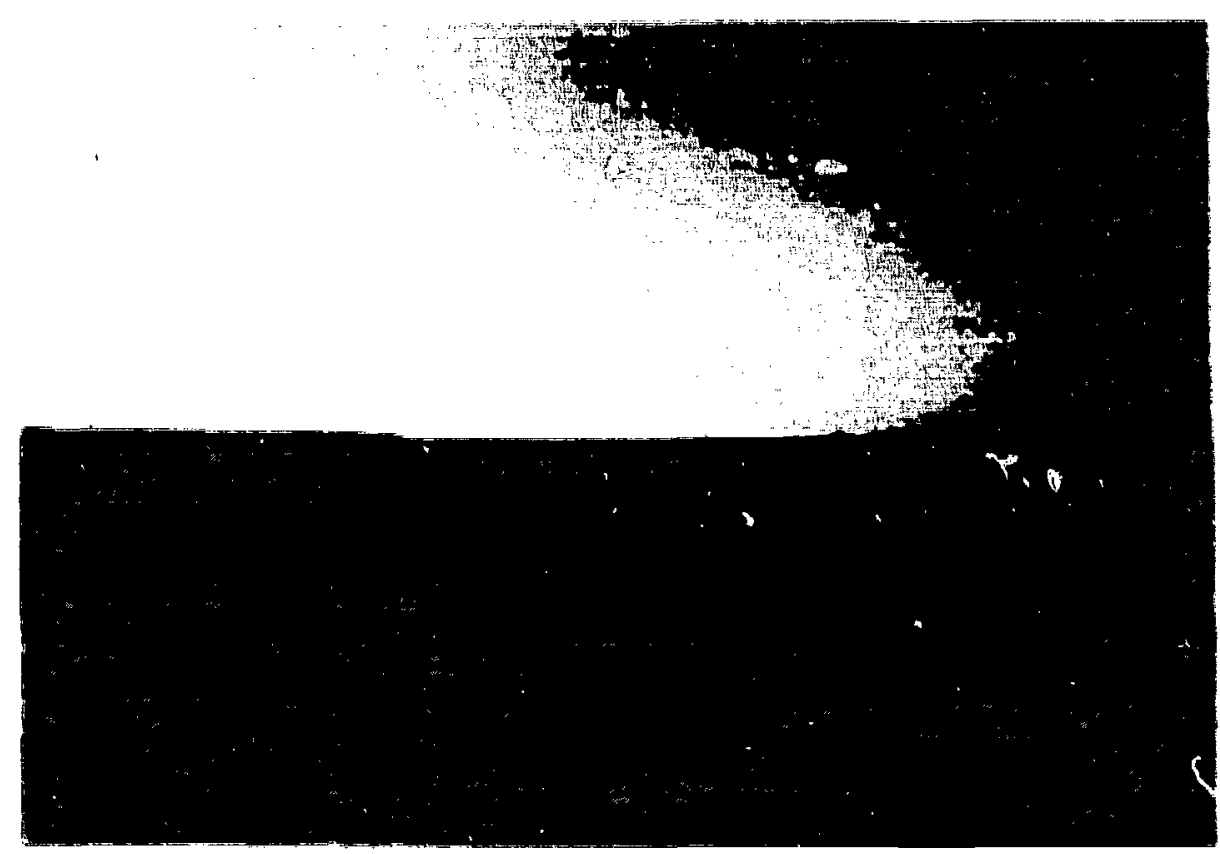

Middleground (1/4-2 mi) View of Proposed Site for Central Facility, Grant County, Oklahoma View Looking Northwest 


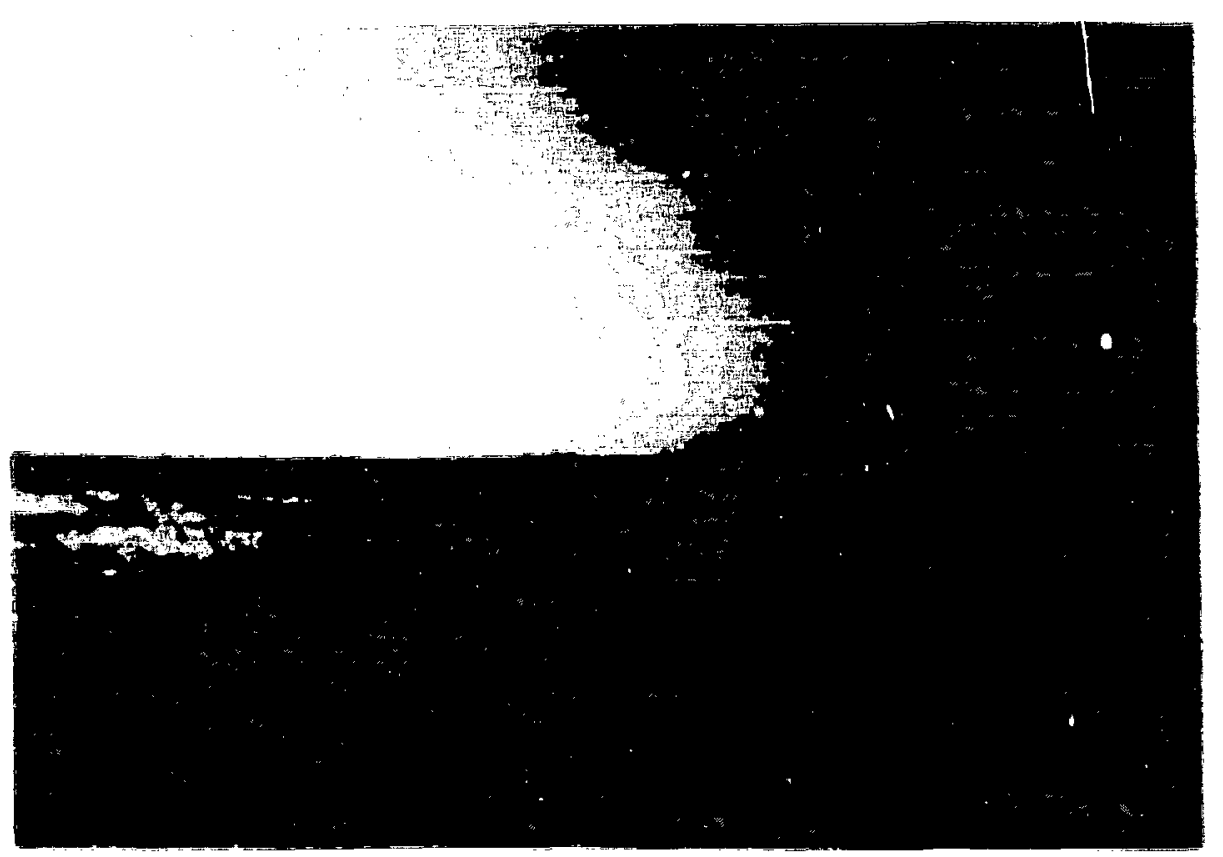

Background (2 - $5 \mathrm{mi}$ ) View of $1 / 4$ Section Containing the Proposed Central Facility, Grant County, Oklahoma

Taken trom Section Foad, $2.2 \mathrm{mi}$ Southeast of Proposed Site - View Looking Northwest 


\section{Appendix |}

National Register of Histortc Places Listings for

Oklahama and Kansas Counties Containing

Central and Boundary Facilities 


\section{Appendix 1}

\section{National Register of Historic Places Listings for \\ Okfahama and Kansas Counties Containing \\ Central and Boundary Facilities}

The following sites are racorded in the National Register of Historic Places as of September 1991 and are located in the counties contrining the ARM program's centrat and boundity factilties. The date of entry into the Nationat Register is givent for eagh listing. The surutes of the intormation are the Kansas State Historical Suciety and the Oblutuma Historicul Susciety.

\section{Grant County, Oklahoma}

Deer Creek Cieneral Merchandise Sture. Suuth Muin Street. Deer Creek (3-8-8-k)

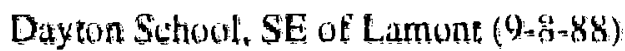

Gant County Courthouse. West Guthrie Street. Medturd $(\alpha=23=8-4)$

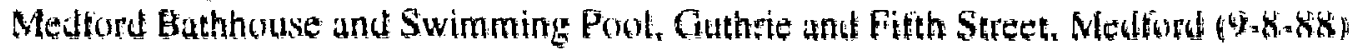

\section{McClain Couaty, Oklahoma}

MeClain County Courthouse, Courthouse Square, Purcell (8-23-84)

\section{Okmulget County, Oklahoma}

Sparhecher touse and Grave, 4 miles west of Beggs $(7-: 2-76)$

tenry Home, North Third Street. Henryetta $(8-18-83$ )

Wilsen School. NW of Henryetto ( $|-28-8|)$

Creak National Capitot, Sixth Street and Grand Ave.. Okmulgee (10-15-ti6)

Eistside Buptist Church, 219 N. Osuge Ave., Okmulgee (11-23.84)

Fiest Baprist Central Church. 521 N. Central Ave.. Okmulgee (11-23-84t)

Okmulges Black Hospital. $320 \mathrm{~N}$. Wood Di. Okmulgee $(6-22-84)$

Okrnulgee County Courthouse. 300) West Seventh Stret. Okmulgee (8-23-34)

Ckmulgee Public Libary. 218 South Okmnlgee Ave.. Oknulgee (7.28-83)

Severs Block, 10)t East Sixth Street, Oknulgee (3-22-9)

S. Azthony's Catholic Church. 515 Sotth Morton Stret, Okmulges (7-14-83)

Nuyaka Mission, 4 miles west of Okrnulges (4-13-72) 


\section{Woodward County, Oklahoma}

Fort Supply Historic District. Westem State Hospital grounds, Fort Supply (6-2L-7L)

L.L. Stein House, 1001 Tenth Street, Woodward (10-7-83);

Woudward Crystal Beach Park, Jim Ben and Temple Houstor. 3̦treets, Woodward (9-8-88)

\section{Kiowa County* Kansas}

Greensbugg Welt. Sycamore Streat, Greensburg (2-23-72)

Belvidere Medicine River Bridge, 25 miles north of Beividere (7-2-85)

Roth Petroglyph Site. Belvidere vicunity (7.9-82)

Star Petroglyph Site, Belvidere vicinity $(7-9,82)$

Fonme-Bipuey Round Bam. 6 miles southwest of Multinville (7-16-87)

\section{Marion County, Kansas}

Bethet Schook. 5 miles east of Lincolnvitle (12-17-87)

Bums Union School, sauthwest conner, Main and Ohio, Burns (3.26.75)

Harvey House, 204 West Third. Forefte $(8-14-73)$

Pionee: Adobe House, US-56 and Ash Street, Hillsboro (3-30-73)

Elgin Hotel. Third and Santa Fe Streets, Marion (9-13-78)

Hill Grade Schoot, 6ol East Main Marion (5-28.76)

Marion County Courthouse. Third and Williarss. Marion (7-2-73)

Old Peabody Libracy. Walnut and Division. Peabody (7-2-73)

Peabody Township Carnegie Library. 214 Wainut. Peaboudy (6-25-87)

Lost Springs. Lask Springs visinity (9.30-76)

Marion Archeolugical Distict. Miarion vicinity $(4-21-76)$

\section{Montgomery County, Kansas}

Cherryvale Camegie Free Libruy. 329 Eas: Main, Chenyvale (\$-18-87)

Brown Mansion. Walnut and Eldridge Sureets. Coffegryille (12-12-76)

Condon National Bonk, 811 Walnut Street. Coffeyville (1-12-73)

Terminal Building. 717 Walnut Street, Colfeyville (6-14-82)

Blakeslee Motor Company Building. 211 West Mytule. independefte (8-25-89)

Bnoth Sotel. 20 1-209 Wast Main, Independence (4-28-83)

Beoth Theatre, 110 West Myrth. Independence (10-13-88)

Federal Building U.S. Pust Office, 123 Noth 8th. Independence (10-19-88)

Independence Bowstring Bridge. Burns Street, Independence (1-4-90)

Independente Public Cirnegie Library, 220 East Maple, Independence (1-11-88)

Pennsylvahia Avenue Rock Croek Bridge. Pennsylvania Avenue over Rock Creek. Intependence (7-2-85) 
Union Implement and Huntware Building-Masonic Temple, 121-123 West Main. tndependence ( $10-13-88)$

Dewlen-Spohnhauer Bridge, 1 mile east of Independence on old US $160(3-10 ;-83)$,

Elk River Archeological District. Elk City vicinity (9-13-78)

Intinity Archeological Site, Elk City Reservoir (3-24-71)

Treaty Roeks Peroglyph Site, Liberty vicinity (7-9-82)

Lookout Station Petroglyph Site, Liberty vicinity $(7-9-82)$

Onion Creek Bridge, 5 miles south of Cotegyilte $(1-4-90)$ )

Petroglyph Site, 14MY365. Liberty vicinity (7-9-82)

Perrgglyph Site, $14 \mathrm{M} Y \mathrm{Y} 1320$ Liberty vicinity $(7,4)-82)$ 
